Hiltraud Casper-Hehne/

Niteen Gupte (Hg.)

\title{
Kommunikation
}

\section{über Grenzen}

Aktuelle Ansätze zur interkulturellen

Verständigung

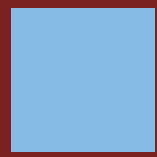

SAniversitätsverlag Göttingen 

Hiltraud Casper-Hehne, Niteen Gupte (Hg.)

Kommunikation über Grenzen

This work is licensed under the Creative Commons License 3.0 "by-nd", allowing you to download, distribute and print the document in a few copies for private or educational use, given that the document stays unchanged and the creator is mentioned.

You are not allowed to sell copies of the free version.

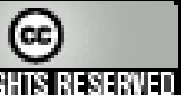

SORE RIGHIS RESERVED 
erschienen im Universitätsverlag Göttingen 2010 


\title{
Kommunikation über Grenzen
}

\author{
Aktuelle Ansätze zur \\ Interkulturellen Verständigung \\ Herausgegeben von \\ Hiltraud Casper-Hehne und \\ Niteen Gupte \\ unter Mitarbeit von \\ Gerhard Stilz
}

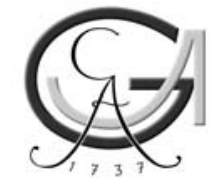

Universitätsverlag Göttingen 2010 


\title{
Bibliographische Information der Deutschen Nationalbibliothek
}

Die Deutsche Nationalbibliothek verzeichnet diese Publikation in der Deutschen Nationalbibliographie; detaillierte bibliographische Daten sind im Internet über $<$ http://dnb.ddb.de> abrufbar.

Gedruckt mit Unterstützung der University of Pune

\author{
Anschrift der Herausgeber \\ Hiltraud Casper-Hehne \\ Georg-August Universität Göttingen \\ Abteilung Interkulturelle Germanistik \\ Käte-Hamburger-Weg 6 \\ 37073 Göttingen \\ Niteen Gupte \\ E-mail: niteen-gupte@t-online.de
}

Dieses Buch ist auch als freie Onlineversion über die Homepage des Verlags sowie über den OPAC der Niedersächsischen Staats- und Universitätsbibliothek (http://www.sub.uni-goettingen.de) erreichbar und darf gelesen, heruntergeladen sowie als Privatkopie ausgedruckt werden. Es gelten die Lizenzbestimmungen der

Onlineversion. Es ist nicht gestattet, Kopien oder gedruckte Fassungen der freien Onlineversion zu veräußern.

Satz und Layout: Niteen Gupte, Somaiyeh Mohammadi

Umschlaggestaltung: Franziska Lorenz, Margo Bargheer

(C) 2010 Universitätsverlag Göttingen

http://univerlag.uni-goettingen.de

ISBN: 978-3-941875-69-2 


\section{Inhalt}

\section{Hiltrand Casper-Hehne}

Interkulturelle Kommunikation aus sprachwissenschaftlicher Perspektive:

Kritische Reflektion der Forschungsansätze und Forschungsergebnisse im

deutsch-indischen Zusammenhang

Sunanda Mabajan

Zugang zur fremden Kultur durch Autobiographien und Familiengeschichten .... 29

Janaki Narkar-Wallraff

Experiences in Intercultural Training in Germany and India. A Comparison

of the German and Indian Mind-set at the Workplace.

Anagha Bhat

Translation as a Tool of Negotiation

Elisabeth Reif

Transkulturelle Psychiatrie. Ein Beitrag zur interkulturellen Verständigung

Manjiri Paranjape

Theater als ein Medium der interkulturellen Kommunikation im

Germanistikstudium in Indien

Gerbard Stil\%.

Can Intercultural Competence be Taught? Forty Years of Mediating Literature

between India and Germany: A Reconsideration

Sharad Deshpande

Hegel in India

Arne Weidemann

Touristische Begegnungen aus der Perspektive einer Psychologie

interkulturellen Handelns.

Maria E. Brunner

Zwischen Fremdwahrnehmung und Selbstverortung -

In mehreren Sprachen leben und schreiben

Niteen Gupte / Anke Müller-Gupte

Indischer Arbeitsplatz aus deutscher Sicht

Pramod Talgeri

Globalisation and Cosmopolitan Identities 



\section{Foreword}

The only thing constant in Life is change, it is said. We tend to believe that we bring about and monitor the change. Yet, more often than not, the outturn is contrary to our expectations. Perhaps, our expectations are firmly rooted in the past. May be our information, experience, and even knowledge invariably belongs to what "has been". The change is therefore, inherently unpredictable. The world is changing. Who would have predicted that the global economy would evolve the way it actually did?

Yes, in a global world, people are more-than-ever mobile. At the same time they need to be connected with their roots as also with the rest of the world. It is essential that persons who need to be mobile for reasons of jobs or education should be well integrated socially and culturally. This helps to bring a new perspective on a professional as well as a personal level. To interact with, and learn about different cultures definitely contributes to personal growth and self confidence. Intercultural communication helps connect people of different countries and generates respect and love for the people on this planet.

Niteen Gupte and his team took this opportunity to organize an international conference on Intercultural Communication. "Communication over Boundaries. Current Approaches towards Intercultural Understanding" was the theme of the interdisciplinary international conference organized from 7th to 9th January 2008 in Pune by the German Section of the Department of Foreign Languages, University of Pune. I was extremely happy to have been invited as the Chief Guest on this occasion, it gave me an opportunity to interact with the highly experienced and motivated stalwarts who participated in the Conference. This publication published 
by the Georg August University of Göttingen, Germany, is an outcome of the Conference.

Communication over Boundaries. Current Approaches towards Intercultural Understanding is a collection of papers presenting the theoretical positions, research methods as well as the practice of the intercultural communication practiced today. It helps the reader to analyze the process that underlies the mechanisms of intercultural understanding.

I congratulate the editors, Niteen Gupte and Hiltraud Casper-Hehne, as also Gerhard Stilz for sequentially placing the articles and for their effort to come up with this unique publication. I am certain that the readers will find this publication interesting and resourceful reading.

\section{Vasudha Garde}

Director, International Centre, University of Pune (India) 


\section{Interkulturelle Kommunikation aus sprachwissenschaftlicher Perspektive: Kritische Reflektion der Forschungsansätze und Forschungsergebnisse im deutsch-indischen Zusammenhang}

Hiltrand Casper-Hehne

\section{Interkulturelle Kommunikation und ihre Erforschung in Deutschland und Indien}

Interkulturelle Kommunikation ist in Deutschland im Zuge zunehmender Globalisierungsprozesse im letzten Jahrzehnt zu einem gängigen Mode- und Schlagwort sowohl in der Alltags- als auch in der Fachwelt geworden, eine Tatsache, die sich in einer Vielzahl und Vielfalt von wissenschaftlichen Publikationen zu diesem Themenbereich niederschlägt. In Indien dagegen stellt sich die Situation anders dar: „Communication over cultural boundaries has been an ideological-political programme of the Indian state ever since its birth", heißt es dazu in der Ankündigung der Tagung „Communication over Boundaries. Current Approaches towards Intercultural Understanding “. 1

1 Communication over Boundaries. Current Approaches towards Intercultural Understanding, Call for Papers, Dept. of Foreign Languages, Univ. of Pune, Pune 2007 
Was die interkulturelle Kommunikationsforschung betrifft, so hat sie sich in Deutschland seit Ende der 80er Jahre zu einem dominanten Forschungsfeld entwickelt, das sich mit der Begegnung unterschiedlicher Kulturen in Wissenschaft, Wirtschaft und Alltag befasst. Anfangs bedingt durch Fehlschläge in der Entwicklungspolitik sowie Kommunikationsschwierigkeiten ausländischer Arbeitnehmer stieg die zunehmende Beschäftigung mit Kultur und interkultureller Kommunikation durch die Ausweitung der internationalen Handelsbeziehungen, die Entwicklung des europäischen Binnenmarktes und die wachsende Zahl von Aussiedlern, Asylanten und anderen Zuwanderern systematisch an und erreicht in den 90er Jahren ihren ersten Höhepunkt.

In Indien hat die zunehmende Globalisierung und wirtschaftliche Entwicklung erst in jüngster Zeit zu einem verstärkten Interesse an der Erforschung der direkten mündlichen Kommunikation zwischen unterschiedlichen Kulturen geführt, und besonders auch der zwischen den Kulturen in Übersee und Indien.

Was die konkrete wissenschaftliche Beschäftigung mit deutsch-indischer interkultureller Kommunikation betrifft, so liegen hier sowohl auf deutscher wie auch auf indischer Seite erst einige wenige Arbeiten vor. Genannt seien hier beispielhaft die Arbeiten von Mitterer/Mimler/Thomas Beruflich in Indien aus dem Jahr $2006^{2}$ oder der Artikel von Vridaghiri Ganeshan zu „Intercultural Misunderstandings between Indians and Germans“" aus dem Jahr 2000³.

Doch das Interesse wächst. War Indien beispielsweise 2003 im Handbuch für Interkulturelle Kommunikation und Kooperation von Thomas/Kammhuber/ SchrollMachl (2003a und b) ${ }^{4}$ noch nicht als Länderstudie integriert, so ist es nun im Handbuch für Interkulturelle Kommunikation und Kompetenz von Straub/Weidemann/ Weidemann (2007) ${ }^{5}$ präsent. Die Universitäten Bremen und Jena sowie das IndoGerman-Chamber of Commerce in Bangalore arbeiten seit 2006 gemeinsam an einem Projekt zu den Differenzen in der deutsch-indischen beruflichen Interaktion (Ganeshan 2000 und 2001), ${ }^{6}$ und an der Universität Pune wurde im Jahr 2007/2008 ein Projekt zur deutsch-indischen Arbeitskommunikation durchgeführt

\footnotetext{
2 Mitterer, Katrin/Mimler, Rosemarie/Thomas, Alexander: Beruflich in Indien. Trainingsprogramm für Manager, Fach- und Führungskräfte, Göttingen 2006

3 Ganeshan, Vridhagiri: Intercultural Misunderstanding between Indians and Germans, -in: Harden, Theo/Witte, Arnd/Riou, Jeanne (ed.): The Notion of Intercultural Understanding in the Context of German as a Foreign Language, Frankfurt/M 2000

4 Thomas, Alexander/Kammhuber, Stefan/Schroll-Machl, Sylvia (Hrsg.) (2003a): Handbuch Interkulturelle Kommunikation und Kooperation. Bd. 1: Grundlagen und Praxisfelder, Göttingen 2003; Thomas, Alexander/Kammhuber, Stefan/Schroll-Machl, Sylvia (Hrsg.) (2003b): Handbuch Interkulturelle Kommunikeation und Kooperation. Bd. 2: Länder und Kulturen und interkulturelle Berufstätigkeit, Göttingen 2003

5 Straub, Jürgen/Weidemann, Arne/Weidemann, Doris (Hrsg.): Handbuch für Interkulturelle Kommunikation und Kompeten₹. Grundbegriffe - Theorien - Anwendungsfelder, Stuttgart-Weimar 2007

${ }^{6}$ vgl. Ganeshan (2000); Ganeshan, Vridhagiri: Mit dem deutschen Kanon auf die indischen Studenten schießen? Deutschsprachige Texte und indische Wahrnehmungsperspektiven, -in: Auer, Michaela/Müller, Ulrich (Hrsg.): Kanon und Text in interkulturellen Perspektiven: „Andere Texte anders lesen“, 4. Internationaler Kongreß d. „Gesellschaft für Interkulturelle Germanistik“ und der Universität Salzburg (Kaprun 23. - 27.9.1998), Stuttgart 2001, S.327-333
} 
(Gupte/Müller-Gupte 2008).7 Zudem entstehen zunehmend wissenschaftliche Arbeiten zu interkulturellen Trainings für die deutsch-indische Zusammenarbeit, etwa die Master-Arbeit von Sabine Kübert (2006) über einen Culture Assimilator. ${ }^{8}$ Trotz allem lässt sich aber konstatieren, dass der Bereich der interkulturellen Kommunikation zwischen Interaktanten aus Indien und Deutschland derzeit noch eine große Forschungslücke darstellt.

Im Folgenden möchte ich deshalb zwei Fragen nachgehen: 1) Welche Forschungsergebnisse liegen bisher zur deutsch-indischen Interaktion vor und wie sind diese zu bewerten; 2) Welcher Forschungsansatz ist tragfähig, um haltbare Ergebnisse zur deutsch-indischen Kommunikation liefern zu können, die sich auch in interkulturellen Trainings umsetzen lassen. Um diesen Fragen nachzugehen, gilt es zuerst zu klären, welcher Kulturbegriff einer derartigen Forschung zugrunde liegen muss.

\section{Ein Kulturkonzept als Ausgangspunkt}

Kultur ist zum einen konstruktivistisch und prozesshaft zu denken. Entsprechend verstehe ich unter Kultur - ganz im Sinne von Clifford Geertz ein von Menschen „selbstgesponnenes Bedeutungsgewebe“, als ein von ihnen erzeugter Gesamtkomplex von Vorstellungen, Denkformen, Empfindungsweisen, Werten und Bedeutungen, die sich in Symbolsystemen materialisieren. ${ }^{10}$ Solche Symbolsysteme können nach Geertz alle Gegenstände, Handlungen, Ereignisse, Eigenschaften oder Beziehungen sein, die Ausdrucksmittel einer Vorstellung sind. ${ }^{11}$

Kultur ist dabei kein homogenes, holistisches Konstrukt. Kulturen sind auch das Ergebnis eines jahrhundertealten und im Zeitalter der Globalisierung beschleunigten Prozesses kultureller Hybridisierung. Dieser resultiert sowohl aus der extremen Binnendifferenzierung immer komplexer werdender moderner Gesellschaften als auch aus deren stetig sich verzweigenden externen Vernetzungen. Kultur ist damit immer auch divers und hybrid, das Ergebnis eines vielschichtigen Überlappungs-, Übersetzungs- und Aushandlungsprozesses. ${ }^{12}$ Dabei ist aber trotz aller drastisch voranschreitender Hybridisierungs- und Globalisierungsprozesse zu bedenken, dass das Konzept einer Transkulturalität, d.h. der kompletten Auflösung der konzeptuellen Grenzen von Einzelkulturen, noch vielfach über den Status quo,

\footnotetext{
7 vgl. Gupte, Niteen/Müller-Gupte, Anke (2008): German Perception of the Indian Workplace. A Study in Intercultural Understanding/Indische Arbeitswelt aus deutscher Sicht. Eine Studie in Interkultureller Verständigung. Pune 2008

8 Kübert, Sabine: Mit Hilfe der Trainingsmethode „Culture Assimilator" interkulturelle Unterschiede verstehen. Ansätze für Indien, Stuttgart 2006

${ }^{9}$ Geertz, Clifford: Dichte Beschreibung: Beiträge zum Verstehen kultureller Systeme, Frankfurt/M. 1987, S.9

${ }^{10}$ vgl. ebd., S.46

11 ebd., S.49

12 vgl. Bachmann-Medick, Doris: Cultural Turns. Neuorientierungen in den Kulturwissenschaften, Reinbek b. Hamburg 2006; Antor, Heinz: 2006, S.29
} 
den wir in der Welt antreffen, hinausgeht. Abdrücke monokultureller, wenn auch deutlich binnendifferenzierter Formationen sind überall noch sichtbar.

Nur mit diesem Kulturbegriff ist auch (und nicht nur) der indischen Gesellschaft gerecht zu werden. Man erinnere nur die Pluralität von Religionen, Sprachen und Kulturen und die typischen Misch- und Überlagerungsformen indischer Kultur, die für die koloniale und postkoloniale Situation kennzeichnend sind. Gerade das für die Untersuchung der interkulturellen Kommunikation mit Interaktanten in Indien und Deutschland grundlegende Konzept von Kultur kann kein holistisches sein. Davor warnt auch Anil Bhatti in seinem Beitrag „Kulturdiskussion in Indien“: „Diskussionen über ,Kultur“ im indischen Zusammenhang sind von der Diversität und der Gleichzeitigkeit verschiedener Gesellschaftsformationen in Indien und auch von der kolonialen und postkolonialen Situation geprägt. Es sei daran erinnert, daß wir es in Indien mit ca. 1.652 Muttersprachen, vier Sprachfamilien und zehn Schriftarten zu tun haben. Mehrere Weltreligionen (Hinduismus, Islam, Christentum, Sikhismus, Janaismus, Buddhismus), animistische Kulte, eine große Zahl von religiösen Sekten und Glaubensrichtungen sind in Indien vertreten. Die ethnische Vielfalt entspricht der subkontinentalen Größe des Landes".13

Geht man in diesen Zusammenhängen von einem homogenen Kulturbegriff aus, ergänzt Bhatti, so führt dies ,[i]m multikulturellen indischen Staat [...] zur Normierung eines hegemonialen Kulturbegriffs, zur Homogenisierung und Nivellierung der Diversität, und dies wiederum [...] zu Dominanz der Majorität [d.h. Hindus] im Staat". 14

Indien stellt nur ein Beispiel dafür dar, dass ein homogener Kulturbegriff der Realität von hybriden und binnendifferenzierten Staaten in keiner Weise gerecht wird. Entsprechend müssen sich auch Forschungskonzepte, die die deutschindische Kommunikation untersuchen wollen, dieser Herausforderung stellen.

\section{Zum Stand der Erforschung interkultureller Kommunikation}

Wie aber befasst sich die interkulturelle Kommunikationsforschung mit diesen Problemen von Diversität und Hybridität? Dazu sollen in einem ersten Schritt die bisherigen wesentlichen Forschungsansätze, und wenn vorhanden, auch ihre Ergebnisse in Bezug auf die deutsch-indische Kommunikation betrachtet werden.

\footnotetext{
13 Bhatti, Anil: Kulturdiskussion in Indien, -in: Ensyklopädie vielsprachiger Kulturwissenschaften, 2000, http://www.inst.at/ausstellung/enzy/kultur/indien_bhatti.htm

14 ebd.
} 


\subsection{Die Kulturanthropologie: das Kulturmodell von Edward T. und Mildred Hall und Indien}

Aus der US-amerikanischen kulturanthropologischen Forschungstradition heraus entwickelte sich die kognitive Kulturanthropologie, die nicht nur die USamerikanische, sondern auch die internationale Erforschung interkultureller Kommunikation weitreichend beeinflusst hat und diese bis heute beeinflusst (Hall/Hall 1983 und Borden 1991). ${ }^{15}$

Edward T. Hall und Mildred R. Hall, zwei führende Vertreter dieser Ausrichtung, führen im Rahmen ihrer anthropologischen Untersuchungen detaillierte, strukturierte Interviews mit Vertretern der Wirtschaft und verschiedenen Berufsgruppen wie Schriftstellern oder Künstlern durch. Die Ergebnisse stellen sie in Verbindung mit einem Modell von Kultursystemen dar, dessen drei Schlüsselelemente die Zeit, den Raum und den Umgang mit „Kontext“ umfassen.

Dabei unterscheiden sie zwei zentrale Arten, wie Menschen mit der Zeit umgehen. Die einen, die „monochronen“, teilen sie ein und konzentrieren sich jeweils in jeder Zeiteinheit nur auf eine Tätigkeit. Die anderen, die als ,polychron“ bezeichnet werden, zerteilen sie. Indien, so Hall/Hall, sei in diesem Zusammenhang eher als polychron, Deutschland als monochron einzustufen. Des Weiteren unterscheiden die Autoren auch in Bezug auf die Zeit zwischen ,vergangenheitsorientierten" Kulturen, wozu sie sowohl Indien als auch Deutschland zählen, sowie zukunftsorientierten Kulturen wie den USA.

Zentrale Unterschiede existieren nach Hall/Hall in Kulturen des Weiteren in Bezug auf die Einstellung zum Raum, weshalb sie zwischen ,kontaktreichen“ und „kontaktarmen“ Kulturen differenzieren. Das dritte Kriterium der Charakterisierung von Kulturen besteht im Umgang mit Kontext. Entsprechend unterscheiden Hall/Hall eine high-context- bzw. low-context-Orientierung. Menschen, die enge Beziehungen zu ihren Mitmenschen besitzen, gehören nach Hall/Hall zur highcontext-Kultur. Sie benötigen weniger detaillierte Informationen über Hintergründe und formulieren deshalb eher indirekt, während low-context-Kulturen direkter kommunizieren. Deutschland sei, so die Autoren, eher low-context-orientiert in Verbindung mit starker kommunikativer Direktheit.

War und ist dieses Kulturmodell sehr einflussreich, so unterliegt es trotz allem grundlegender Kritik. Sie besteht vor allem darin, dass die Autoren ein absolut kohärentes holistisches und statisches Bild von nationalen Kulturen entwerfen, das zu Stereotypisierungen führt und zudem für die interkulturelle Interaktion keinen Freiraum der prozesshaften Gestaltung von Neuem zulässt. Die interkulturelle Interaktion wird auf die Realisierung der Verhaltensweisen aus den Ausgangskulturen der Beteiligten und ihrer Werte festgeschrieben.

\footnotetext{
${ }^{15}$ Hall, Edward T./Hall, Mildred: Verborgene Signale. Studien zur internationalen Kommunikation. Über den Umgang mit Amerikanern, Santa Fe-Hamburg 1983; Borden, G. A.: Cultural Orientation. An approach to understanding intercultural communication, Englewood Cliffs 1991
} 
Noch immer orientieren sich aber zahlreiche Projekte und auch praktische interkulturelle Trainings an diesen Konzepten. So basiert beispielsweise ein von der Universität Bremen, der Universität Jena und dem Indo-German Chamber of Commerce, Bangalore, durchgeführtes Projekt zu imaginierten und realen Differenzen in der deutsch-indischen beruflichen Interaktion auf dem Ansatz von Hall/Hall. ${ }^{16}$ Und auch die Master-Arbeit der Autorin Sabine Kübert aus dem Jahr 2006 stützt sich in Teilen indirekt auf dieses Modell. ${ }^{17}$

\subsection{Die Sozialpsychologie I: das Kulturmodell von Geert Hofstede und Indien}

Ein zweites Kulturmodell übt über das obige Modell hinaus einen starken Einfluss auf Forschung und Lehre im Bereich der interkulturellen Kommunikation aus. Es wurde von dem niederländischen Sozialpsychologen Geert Hofstede entwickelt, der in einer Erhebung arbeitsrelevante Werte und Einstellungen aus über 40 Ländern mit Hilfe von ca. 120.000 Fragebogen beim IBM-Konzern eruierte. Auf der Grundlage dieser Fragebogen entwickelte Hofstede vier (später fünf) zentrale Dimensionen von Kulturen, die universale Handlungsorientierungen betreffen und die Kommunikation beeinflussen sollen. Seine Arbeit prägte zahlreiche wirtschaftswissenschaftliche, aber auch linguistische Untersuchungen im In- und Ausland in den 80er und 90er Jahren entscheidend mit und ist auch heute noch einflussreich. Hofstedes Publikation Lokales Denken, Globales Handeln wurde erst jüngst in Deutschland in vierter Auflage veröffentlicht. ${ }^{18}$

Hofstede geht davon aus, dass alle Gesellschaften mit den gleichen Problemen konfrontiert werden. Die Problembereiche nennt Hofstede „Dimensionen der Kultur“ und fasst darunter „Individualismus - Kollektivismus“, „Femininität Maskulinität“, „Machtdistanz“ und „Unsicherheitsvermeidung“. Zusammen ergeben diese vier Bereiche das ,4-D-Modell““.19

Eine bedeutsame Dimension des Modells stellt die Machtdistanz dar, durch die die Art und Weise gekennzeichnet wird, mit der Personen mit der Tatsache der Ungleichheit umgehen. In diesem Zusammenhang sieht Hofstede Indien gegenüber Deutschland als Land mit einem höheren Grad an Machtdistanz.

Eine weitere Dimension umfasst die Individualismus-KollektivismusOrientierung. Individualismus bezieht sich auf Gesellschaften, in denen die Bindungen zwischen Individuen verhältnismäßig lose sind; Kollektivismus dagegen

16 vgl. Srinivasan, Anuradha: Das Fremdbild, das Selbstbild und das Metabild - die imaginären und realen Differenzen deutsch-indischer beruflicher Interaktionen. Ergebnisses des Projekts INTERMAN, Abstract, 2007, http://www.uta.fi/laitokset/kielet/yht/tutkimus/GIG-Tagung2007/abstracts.pdf

${ }^{17}$ Kübert (2006)

18 Hofstede, Geert/Hofstede, Gert Jan: Lokales Denken, globales Handeln. Interkulturelle Zusammenarbeit und globales Management, übers. aus d. Engl. v. P. Mayer u. M. Sondermann, München ${ }^{2} 2009$ (1., englischspr. Aufl. 1980), weiterhin wird die 3. Aufl., München 2006, zitiert als Hofstede (2006).

19 Hofstede, Geert: Interkulturelle Zusammenarbeit. Kulturen - Organisationen - Management, Wiesbaden 1993, S.29 
referiert auf Kulturen, in denen Menschen von Geburt an in starke, kohäsive Gruppen integriert sind. Nach Hofstede ist Indien deutlich kollektivistisch orientiert, Deutschland im Vergleich dazu eher individualistisch.

Die dritte Dimension umfasst die von Hofstede so genannten Aspekte der „Maskulinität“ und „Femininität“. In maskulinen Gesellschaften spielen Werte wie Leistung, Anerkennung, Aufstieg und Herausforderung gewöhnlich eine herausragende Rolle, in femininen dagegen besitzt eher die Beziehung zu Arbeitskollegen, Lebensqualität und Kooperation eine große Bedeutung. ${ }^{20}$ In dieser Dimension kennzeichnet Hofstede Indien und Deutschland beide als eher maskulin orientiert.

Die vierte Dimension bei Hofstede betrifft die Unsicherheitsvermeidung. Mit ihr wird das Ausmaß beschrieben, in dem Mitglieder einer Kultur sich durch unsichere Situationen bedroht fühlen. Diese sei in Deutschland deutlich höher als in Indien, entsprechend seien Deutsche auch regel- und organisationsorientierter.

War und ist Hofstedes Modell einflussreich, so sind auch hier große Bedenken anzubringen.

Insgesamt gilt zu kritisieren, dass allein mittels Fragebogen zentrale Unterschiede (allgemeine Werte, Normen u.ä.) zwischen den Kulturen erhoben werden. Kotthoff weist in diesem Zusammenhang darauf hin, dass Menschen sich oft ihrer Verhaltensdimensionen gar nicht bewusst seien und deshalb Befragungen, seien es Interviews oder Fragebögen, allein nicht ausreichen könnten. ${ }^{21}$ Wichtiger wäre, auch das konkrete, tatsächlich ablaufende interkulturelle Gespräch in den Blick zu nehmen. Entsprechend können auch diese Untersuchungen nur begrenzt Aussagen über die tatsächlich ablaufenden Interaktionsvorgänge in interkulturellen Gesprächen machen.

Zudem, und dies stellt einen zentralen Einwand dar, geht auch Hofstede von einem stark holistischen Ansatz von Kulturen aus, ohne zum einen jegliche Binnendifferenzierung in Betracht zu ziehen (spätere Studien versuchen, religiöse Differenzierungen einzuarbeiten) oder zum anderen Globalisierungstendenzen in den Blick zu nehmen. Immer wieder wurde auch die Repräsentativität der gezogenen Stichproben in Frage gestellt ${ }^{22}$ und damit auch die Tragfähigkeit der Ergebnisse.

\subsection{Die Sozialpsychologie II: das Kulturmodell von Alexander Thomas und Indien}

Als drittes Modell beeinflusste insbesondere das Kulturstandardmodell von Alexander Thomas die interkulturelle Forschung und Praxis. Dieses Konzept ist mitt-

\footnotetext{
20 ebd., S.81f

${ }^{21}$ Kotthoff, Helga (2002a): Kultur(en) im Gespräch, -in: Kotthoff, Helga (Hrsg.) (2002): Kultur(en) im Gespräch, Tübingen 2002, S.7-22, S.12

${ }^{22}$ McSweeney, Brendan (2002): Hofstede's Model of National Cultural Differences and Their Consequences: A Triumph of Faith - A Failure of Analysis, -in: Human Relations, Jg. 55, Heft 1, 2002, S.89119
} 
Hiltraud Casper-Hehne

lerweile stark verbreitet und in über 20 Monographien zu spezifischen Nationalkulturen weiterentwickelt worden. Kultur ist für Thomas ein für die Angehörigen einer Nation sinnstiftendes Orientierungssystem. ${ }^{23}$ Kulturstandards sind danach Arten des Wahrnehmens, Denkens, Wertens und Handels, die von einer Mehrzahl der Mitglieder einer bestimmten Kultur für sich und andere als normal, typisch und verbindlich angesehen werden. ${ }^{24}$

Die jeweiligen Kulturstandards einer Nationalkultur werden in diesem Ansatz durch Befragungen von Fach- und Führungskräften, die seit mehreren Jahren in dem entsprechenden Land tätig sind, erarbeitet. Die Berichte der Führungskräfte werden sodann durch bikulturelle Experten aus Deutschland und dem jeweiligen Ausland auf ihre kulturspezifischen Ursachen hin diagnostiziert und in Bezug auf Kulturstandards systematisiert.

Für Indien beispielsweise entwickelten Mitterer, Mimler und Thomas (2006) neun Kulturstandards. ${ }^{25}$ Entsprechend seien in Indien alle Lebensbereiche von folgenden Standards geprägt:

- von strengen hierarchischen Strukturen (Autoritätsorientierung, Verantwortungsdelegation nach oben, Statusorientierung),

- von Rollenkonformität (strenge Rollenerwartungen, denen gefolgt wird),

- von Personalismus (informelle Beziehungsnetzwerke spielen eine große Rolle),

- von Familienorientierung (die Familie und das Wohl der Familie genießt einen hohen Stellenwert),

- von Paternalismus (von der männlichen Autoritätsperson wird sowohl autoritäres als auch väterlich-fürsorgliches Verhalten erwartet),

- von Konfliktvermeidung (Inder sind bestrebt, Konflikten aus dem Weg zu gehen; indirekte Kritik, Fehler werden nicht eingestanden);

- von Emotionalität (Inder werden eher vom Herzen geleitet als vom Verstand; emotionale Nähe zu einer Person ist wichtig),

- von Polychronie (in Indien neigen die Menschen dazu, mehrere Aufgaben simultan zu erledigen), und

- von Fatalismus (in Indien gehen die meisten Menschen davon aus, dass die meisten Ereignisse von äußeren Faktoren bestimmt werden und daher nur bedingt beeinflussbar sind; das Schicksal des Menschen hängt von den Taten in seinem vorherigen Leben $\mathrm{ab}$ ).

Für Deutschland gilt nach dem Konzept von Schroll-Machl dagegen eine hohe Sachorientierung, die große Wertschätzung von Strukturen und Regeln (Unsicher-

\footnotetext{
23 Thomas, Alexander: Kultur und Kulturstandards, in: Thomas, Alexander/Kammhuber, Stefan/Schroll-Machl, Sylvia (Hrsg.): Handbuch Interkulturelle Kommunikation und Kooperation. Bd. 1: Grundlagen und Praxisfelder, Göttingen 2003, S.19-31, S.24

24 ebd., S.25

25 Mitterer, Katrin/Mimler, Rosemarie/Thomas, Alexander: Beruflich in Indien. Trainingsprogramm für Manager, Fach- und Führungskeräfte, Göttingen 2006
} 
heitsvermeidung), eine präzise Zeitplanung (monochron), eine internalisierte Kontrolle der Organisation (Unsicherheitsvermeidung), die strikte Trennung von Persönlichkeits- und Lebensbereichen (Arbeit, Familie) sowie eine schwache Kontextorientierung (große Direktheit und Explizitheit). ${ }^{26}$

Auf der Basis der Arbeiten von Mitterer/Mimler/Thomas sowie der von Hofstede hat Sabine Kübert in der schon erwähnten Masterarbeit ein Culture Assimilator Training für Indien entwickelt, das sich stark an diesen Kulturstandards orientiert.

Eine Kritik an dem Kulturstandardkonzept besteht darin, dass Kulturstandards nur im Kontrast zu einer bestimmten zum Vergleich herangezogenen Kultur gelten. ${ }^{27}$ Damit können die ermittelten Kulturstandards bei ein- und demselben Land abhängig von der Vergleichskultur und somit dem Blickwinkel, aus dem eine Kultur betrachtet wird, erheblich divergieren. So wird z.B. Österreich einerseits aus der Sicht Belgiens und Ungarns durch eine starke Regelorientierung, andererseits aber aus der Sicht Deutschlands und der Schweiz durch eine schwache Regelorientierung charakterisiert.

Zudem geht das Kulturstandardkonzept davon aus, dass die Standards zwar historischen, aber keinen kurz- und mittelfristigen Veränderungen unterliegen. Da sich Kulturstandards aber auch kurz- und mittelfristig verändern, wird dieser Tatsache bei einer mittels der Kulturstandardmethode durchgeführten Momentaufnahme - ohne eine Längsschnittanalyse - nicht Rechnung getragen.

Neben dieser historischen Variabilität sind Kulturen zudem, wie schon oben ausgeführt, von Binnenheterogenität und Hybridität geprägt, was beim Kulturstandardmodell weitgehend vernachlässigt wird. ${ }^{28}$ Zugehörigkeit zu Subgruppen innerhalb der Kultur (wie Beruf, Organisationskultur, Bildungs- und Sozialstatus), Elemente der persönlichen Identität des Befragten (fachliche und soziale Kompetenz, Persönlichkeitsmerkmale) sowie Einflüsse der Intergruppenbeziehungen (Stereotype, Geschichte der Intergruppenkontakte) werden nicht berücksichtigt. Dem Konzept liegt ein eindeutig homogener Kulturbegriff zugrunde. Insgesamt neigen Kulturstandards deshalb zu einem hohen Grad an Stereotypisierungen, ja die Ergebnisse der Kulturstandardmethoden korrespondieren sogar mit vielen Aussagen der Stereotypenforschung.

Da Thomas davon ausgeht, dass diese Kulturstandards auch Arten des Wahrnehmens darstellen, kann nur im Sinne Vridhagiri Ganeshan kritisch reflektiert werden:

\footnotetext{
${ }^{26}$ Schroll-Machl, Sylvia: Deutschland, -in: Thomas, Alexander/Kammhuber, Stefan/Schroll-Machl, Sylvia (Hrsg.): Handbuch Interkulturelle Kommunikation und Kooperation. Bd. 2: Länder und Kulturen und interkulturelle Berufstätigkeit, Göttingen 2003, S.72-89

${ }^{27}$ vgl. Krewer, Bernd: Kulturstandards als Mittel der Selbst- und Fremdreflexion in interkulturellen Begegnungen, -in: Thomas. Alexander (Hrsg.): Psychologie interkulturellen Handelns, Göttingen, 1996, S.110-135, http://www.krewerconsult.de/docs/Kulturstandards $\% 20 \mathrm{als} \% 20$ Mittel $\% 20$ der $\% 20$ Selbst$\% 20$ und $\% 20$ Fremdreflexion.pdf

${ }^{28}$ vgl. ebd.
} 
„E i n e indische Wahrnehmungsperspektive gibt es eigentlich nicht, denn es gibt so viele indische Wahrnehmungsperspektiven wie es Inder gibt. Es gibt nicht nur eine ländliche, städtische, klassische oder folkloristische indische Wahrnehmungsperspektive. Je nach der Religions- und Kastenzugehörigkeit, je nach der sprachlich bezogenen Identität, je nach der geographischen Identität innerhalb Indiens, je nach dem sozialen Status, je nach der beruflichen Identität usw. gibt es diverse indische Wahrnehmungsperspektiven. In Indien sprechen wir von der 'Unity in diversity' (Einheit in der Vielfalt). [...] Was wir in Indien heute sehen, ist nichts spezifisch Indisches. Die ganze Welt ist in Indien“. ${ }^{29}$

\subsection{Drei weitere Modelle der Erforschung}

Kurz soll im Folgenden auf drei weitere Ansätze eingegangen werden, die sich aber bisher noch nicht mit der deutsch-indischen Kommunikation befasst haben: kontrastive linguistische Ansätze, die Interlanguage Pragmatics und die funktionale Pragmatik.

\subsubsection{Kontrastive linguistische Ansätze}

Kontrastive Ansätze der interkulturellen Kommunikationsforschung befassen sich mit dem Vergleich intrakultureller Interaktionseinheiten. Dabei existieren mittlerweile verschiedene theoretische und methodische Konzepte. Darauf kann an dieser Stelle aber nur kurz eingegangen werden.

Die kontrastive Pragmatik analysierte anfangs die Realisierung bestimmter Sprechakte in verschiedenen Sprechergemeinschaften. Methodisch arbeitet der traditionelle Zweig dieser Forschung vor allem mit Fragebögen und Testsituationen, die die situative Angemessenheit von einzelnen Sprechakten eruieren. Neuere Arbeiten befassen sich auch stärker mit der Analyse natürlicher Gespräche. ${ }^{30}$

\footnotetext{
${ }^{29}$ Ganeshan (2000), S.332

30 z.B. Niehaus-Lohberg, Erika/Herrlitz, Wolfgang: Verständigung zwischen Niederländern und Deutschen: Ein Beitrag zur Analyse der interkulturellen Kommunikation zwischen Unternehmen, -in: Bungarten, Theo (Hrsg.): Sprache und Kultur in der interkulturellen Marketingkommunikation, Tostedt: 1994, S.143-166; Stolt, Birgit: Kulturbarrieren als Verständigungsproblem, -in: Reuter, Ewald (Hrsg.): Wege der Erforschung deutsch-finnischer Kulturunterschiede in der Wirtschaftskommunikation, Tampere 1992, S.28-46; Muikku-Werner, Pirkko: Sind die Finnen Barbaren? Kontrastive Analyse deutscher und finnischer Abschwächungstechnik, -in: Reuter (1992), ebd., S.75-100; Kuhn, Elisabeth D.: Gender and Authority. Classroom Diplomacy at German and American Universities, Tübingen 1983; vgl. Nuopponen, Anita/Harakka, Terttu/Tatje, Rolf (Hrsg.): Interkulturelle Wirtschaftskommunikation. Forschungsobjekte und Methoden, Vaasa 2002; Neidert, Christina: Imagearbeit in Fernsebserien - kontrastiv. Vergleich der Muster und Sequenzen in amerikanischen und deutschen Seriendialogen, Frankfurt/M. 2001; Tiittula, Liisa (2001a): Argumentationsstile in deutschen und finnischen Fernsehsendungen, -in: Jakobs, Eva-Maria/Rothkegel, Annely (Hrsg.): Perspektiven auf Stil, Tübingen 2001, S.205-227; Tiittula, Liisa (2001b): Normen und Normvorstellungen in deutschen und finnischen Fernsehdiskussionen, -in: Breuer, Ulrich/Korhonen, Jarmo Antero (Hrsg.): Mediensprache - Medienkritik, Frankfurt/M 2001, S.253-271; Tiittula, Liisa (2001c): Adressierung in deutschen und finnischen öffentlichen Diskussionen, -in: Lüger, HansHelmut (Hrsg.): Höflichkeitsstile, Frankfurt/M, S.277-294; Liang, Yong: Höflichkeit im Chinesischen. Geschichte - Konzepte - Handlungsmuster, München 1998; Rathmeyr, Renate: Höflichkeit als kulturspezifisches Konzept. Russisch im Vergleich, -in: Ohnheiser, Ingeborg (Hrsg.): Wechselbeziehungen zwischen
} 
Nach Untersuchungen der traditionellen kontrastiven Pragmatik sollen deutsche Studierende Sprechakte wie Beschuldigungen, Beschwerden, Aufforderungen oder Bitten direkter als britische formulieren, so jedenfalls Juliane House. ${ }^{31}$ Sie spricht sogar insgesamt von einer stärkeren Beziehungsorientierung der britischen Sprecher. Aufforderungen wiederum würden nach Rathmeyr von russischen Sprechern direkter formuliert als von deutschen. ${ }^{32}$ Sagt ein deutscher Sprecher etwa „Könntest Du mir bitte helfen?“", schwäche er also die Bitte durch Partikel, Fragesatz und Konjunktiv II ab, würde ein russischer Sprecher eher einen Aussagesatz im Indikativ mit der Partikel „bitte“ verwenden, wie „Hilf mir bitte!“. Oder: Im Chinesischen erfolgt nach Liang zur Konfliktvermeidung eine permanente Zurückdrängung des Ich. Entsprechend würde eine Beschwerde z.B. mit der Äußerung realisiert werden: „Wie ich von allen gehört habe, bist du in letzter Zeit oft zu spät gekommen“. ${ }^{33}$ Und nach Muikku-Werner bevorzugten finnische Moderatoren bei Fragen, Nachfragen und Befehlen gerne elliptische Formen (,Ja, oder Nein, Kristina Halkola“, statt „Antworten Sie doch bitte mit ja oder nein, Kristina Halkola $\left.{ }^{6}\right) .{ }^{34}$ Die finnischen Sprecher, so die Schlussfolgerung, gingen eher geizig mit Worten um.

Besonders auffällig ist, so kann man diese Ergebnisse zusammenfassen, dass gerade in diesen Forschungen zahlreiche Nationalstereotype linear fortgeschrieben werden, etwa zum höflichen Briten, zum wortkargen Finnen oder zum höflichen Chinesen. Insgesamt ist dieser spezifische Ansatz stark von einem homogenen Kulturverständnis geprägt.

Alle Arbeiten dieser Richtung fußen zudem auf dem kontrastiven Vergleich von Sprachkonventionen, während das eigentliche interkulturelle Gespräch nicht im Mittelpunkt der Betrachtung steht und insofern darüber auch keine Aussagen gemacht werden können. Es wird in diesem Konzept des Weiteren davon ausgegangen, dass das interkulturelle Gespräch lediglich eine Reproduktion der sprachlichen Konventionen darstellt, die in der Eigenkultur der Interaktanten erworben wurden. Doch in interkulturellen Gesprächen kommen auch andere als in der Ausgangskultur der Interaktanten erworbene Verhaltensweisen zum Tragen ${ }^{35}$ (s. Kapitel 4.4.).

\footnotetext{
slawischen Sprachen, Literaturen und Kulturen in Vergangenheit und Gegenwart, Innsbruck 1996, S.174-185; House, Juliane: Contrastive discourse analysis and universals in language use, -in: Papers and Studies in Contrastive Linguistics, 20, 1985, S.5-14

31 House, Juliane (1982b): Conversational strategies in German and English dialogues, -in: Nickel, Gerhard/Nehls, Dietrich (Hrsg.): Error analysis, contrastive linguistics and second language learning, Heidelberg 1982, S.136-150

32 Rathmeyr (1996)

33 nach Liang (1998), S.225

${ }^{34}$ Muikku-Werner (1992)

35 vgl. Koole, Tom/ten Thije, Jan (1994a): The Construction of Intercultural Discourse: Team Discussions of Educational Advisers, Amsterdam-Atlanta 1994; Koole, Tom/ten Thije, Jan (1994b): Der interkulturelle Diskurs von Teambesprechungen. Zu einer Pragmatik der Mehrsprachigkeit, -in: Brünner, Gisela/Graefen, Gabriele (Hrsg.): Texte und Diskurse. Methoden und Forschungsergebnisse der Funktionalen Pragmatik, Opladen 1994, S.412-434; Koole, Tom/ten Thije, Jan: The Construction of Intercultural Dis-
} 


\subsubsection{Interlanguage Pragmatics}

Einige wenige Forschungsrichtungen im Gegensatz zu oben aufgeführten Ansätzen gehen von der konkreten Aufzeichnung interkultureller Gespräche aus, so zum Beispiel die relativ junge Forschungsdisziplin der Interlanguage Pragmatics. Im Vordergrund stehen pragmalinguistische Probleme zwischen dem MuttersprachlerSprachsystem und dem Lernersprachsystem, der Interlanguage. Untersucht wird, wie Nichtmuttersprachler Sprechakte auswählen und realisieren. ${ }^{36}$ Die Ergebnisse zeigen, dass Lerner in Sprechakten oft die notwendige illokutionäre Kraft oder Höflichkeit nicht angemessen formulieren können, was vor allem als pragmatisches Defizit in der Interlanguage erklärt wird. Zudem werden aber auch intralinguale Ursachen für pragmatische Fehler verantwortlich gemacht (etwa Übergeneralisierung, Simplifizierung oder Reduktion von Wissen). Die Ergebnisse dieser Untersuchungen bieten wichtige Aufschlüsse über Probleme, die Fremdsprachenlerner in der interkulturellen Kommunikation haben können. Sie geben damit Erklärungshinweise für Äußerungsformen in der Lernersprache und müssen deshalb bei der Betrachtung und Analyse interkultureller Kommunikation immer mit berücksichtigt werden, wenn auch nicht alleine.

\subsubsection{Die funktionale Pragmatik}

Eine weitere, auch interkulturell orientierte Forschungsrichtung stellt die von Jochen Rehbein und Konrad Ehlich begründete funktionale Pragmatik dar. ${ }^{37}$ Dieser Forschungsansatz verwendet ebenso wie die Interlanguage Pragmatics interkulturelle Gespräche als Datengrundlage und untersucht vor allem das Musterhandlungswissen in interkulturellen Gesprächen, wobei dieses aber sehr stark auf der Ebene von Sprechakten angesiedelt ist und keine größeren Einheiten im Gespräch integriert. Zudem wird damit lediglich eher auf die kognitive Tiefenstruktur von

course: Team Discussions of Educational Advisers, -in: Journal of technical writing and communication, 25 , 2, 1995, S.225-228; Rasmussen, Gitte: Zur Bedeutung kultureller Unterschiede in interlingualen interkulturellen Gesprächen. Eine Mikroanalyse deutschsprachiger Interaktionen zwischen Franzosen und Dänen und zwischen Deutschen und Dänen, München 2000; ten Thije, Jan D.: Stufen des Verstehens bei der Interpretation von interkulturellen Diskursen, -in: Kotthoff (2002), S.61-98

${ }^{36}$ vgl. beispielsweise Kotthoff, Helga: Pro und Kontra in der Fremdsprache. Pragmatische Defizite in interkulturellen Argumentationen, Frankfurt/M 1989

37 vgl. Redder, Angelika (Hrsg.): Kommunikation in Institutionen, Bremen 1983; Rehbein, Jochen: Institutioneller Ablauf und interkulturelle Mißverständnisse in der Allgemeinpraxis. Diskursanalytische Aspekte der Arzt-Patient-Kommunikation, -in: Curare, 9, 1986, S.297-328; Rehbein, Jochen (1994a): Widerstreit. Semiprofessionelle Rede in der interkulturellen Arzt-Patienten-Kommunikation, -in: Klein, Wolfgang/Dittmar, Norbert (Hrsg.): Interkulturelle Kommunikation, Göttingen 1994, S.123-151; Rehbein, Jochen (1994b): Rejective proposals: Semi-professional speech and clients' varieties in intercultural doctor-patient communication, -in: Multilingua. Journal of Cross-cultural and Interlanguage Communication, 13, 1/2, 1994, S.83-130; Redder, Angelika/Rehbein, Jochen: Arbeiten zur interkulturellen Kommunikation, Bremen 1987; Redder, Angelika (Hrsg.) (1994a): Diskursanalysen in praktischer Absicht, Oldenburg 1994; Redder, Angelika (1994b): „Bergungsunternehmen“ - Prozeduren des Malfeldes beim Erzählen, -in: Brünner, Gisela/Graefen, Gabriele (Hrsg.): Texte und Diskurse. Methoden und Forschungsergebnisse der Funktionalen Pragmatik, Opladen 1994, S.238-264; Koole/ten Thije (1994a, 1994b, 1995); Schilling, Andrea: Bewerbungsgespräche in der eigenen und fremden Sprache Deutsch. Empirische Analysen, Frankfurt/M 2001; ten Thije (2002) 
Kommunikation rekurriert, als die Erscheinungen der sprachlichen Realisierung differenziert zu analysieren.

Ebenso wie in der kontrastiven Pragmatik geht man darüber hinaus - zumindest in älteren Arbeiten ${ }^{38}$ - davon aus, dass die in der Ausgangskultur der Interaktanten erworbenen sprachlichen Verhaltensweisen direkt in das interkulturelle Gespräch transferiert werden und damit Missverständnisse entstehen. ${ }^{39}$ Auch hier steht in den meisten Fällen nicht der prozesshafte Charakter von interkultureller Kommunikation, d.h. der Aushandlungsprozess im Fokus. Zudem ist auch in diesem Konzept der zugrundeliegende Kulturbegriff homogen konturiert.

\subsection{Die interpretative Soziolinguistik}

Ein Ansatz, dessen Ausgangspunkt die ethnomethodologische Konversationsanalyse darstellt, und bei dem als Datengrundlage ebenfalls konkrete aufgezeichnete interkulturelle Gespräche Verwendung finden, besteht in der interpretativen Soziolinguistik, entwickelt von John Gumperz. Sein Ansatz geht davon aus, dass wir als Mitglieder einer Kultur mit soziokulturellem Wissen auch bestimmte Interaktionskonventionen erwerben, die uns jedoch meist nicht voll bewusst sind. Kommunizieren wir mit Angehörigen einer anderen Kultur, so konstruieren wir mit ihnen unsere Interaktion und interpretieren die Äußerungen der Gesprächspartner.

Mit Hilfe von non- und paraverbalen Kontextualisierungshinweisen (z.B. Lachen) werden Schemata des soziokulturellen Hintergrundwissens verfügbar gemacht, wobei diese jeweils kulturell geprägt sind: Bestimmte Kontextualisierungshinweise verweisen in unterschiedlichen Kulturen auf unterschiedliche Schemata des Hintergrundwissens.

Diesen Ansatz hat Gumperz in einer größeren Studie zur indisch/pakistanischbritischen Kommunikation exemplifiziert. Der Ausgangspunkt der Studie bestand darin, dass das sprachliche Verhalten von Indern und Pakistani, die in einem Flughafenrestaurant bedienten, von Kunden als unhöflich eingestuft wurde. Linguistische Untersuchungen der Gespräche ergaben, dass besonders die Inder bei Fragen fallend betonten, so wie sie es in ihrer Muttersprache Hindi gewohnt waren. Auf Briten wirkt diese fallende Betonung unhöflich. Gumperz resümiert, dass in diesem Falle muttersprachliche Kontextualisierungshinweise (fallende Betonung für Höflichkeit) auf die Fremdsprache übertragen wurden und zu Missverständnissen führten.

Diese Methode ermöglicht die Analyse kulturspezifischer Handlungs- und Interpretationsweisen sowie die Analyse der Wirksamkeit oder der Modifikation in der interkulturellen Kommunikation, aber die Frage, ob eine sprachliche Handlung kulturspezifisch ist oder nicht, kann nach dieser Methode nur geklärt werden, wenn die Kommunikationsteilnehmer diese Unterschiede in der Kommunikation

\footnotetext{
38 z.B. Redder/Rehbein (1987)

39 anders Rehbein (2007)
} 
lokal relevant machen (durch Kontextualisierungshinweise). Das Konzept der Kontextualisierungshinweise erfasst damit aber nicht alle Möglichkeiten von Missverständnisursachen. ${ }^{40}$ So stellt Rehbein in seinem Ansatz der funktionalen Pragmatik dagegen dar, dass auch unterschiedliche kulturelle Handlungsmuster, die nicht an der Oberfläche sichtbar werden, zu Problemen in der Kommunikation führen können. ${ }^{41}$

Gumperz betont des Weiteren - ebenso wie die kontrastive und die funktionale Pragmatik - in seinem Ansatz zu sehr den statischen Einfluss der Kultur auf das Kommunikationsverhalten. Trotz der zahlreichen kritischen Punkte beziehen sich zahlreiche neuere Arbeiten auf diesen Ansatz. Dabei rekurrieren die meisten der neueren Arbeiten auch auf einen homogenen Kulturbegriff.

\subsection{Interkulturelle Kommunikationsforschung: kritischer Rückblick}

Fasst man die Kritik an den dargestellten Forschungsansätzen und Methoden noch einmal zusammen, so lassen sich folgende Punkte aufführen. Die hier aufgeführten anthropologischen und sozialpsychologischen Arbeiten neigen zu starken Stereotypisierungen. Untersuchungen der kontrastiven Pragmatik (vergleichende Sprechaktanalysen) z.B. arbeiten häufig mit Fragebogenerhebungen und schließen von intrakulturellen Situationen auf interkulturelle. Interlanguage Pragmatics-Vertreter betrachten zwar das interkulturelle Gespräch, konzentrieren sich aber sehr stark auf die Analyse von Sprechakten, ohne den Ko- und Kontext mit einzubeziehen. Die funktionale Pragmatik erarbeitet die kognitiven Muster sprachlicher Handlungen, beschränkt sich damit aber nur auf einen globalen Aspekt der sprachlichen Analyse. Bei der ethnomethodologischen Konversationsanalyse, die Missverständnisse nur lokal im Gespräch ausmachen will, besteht die Gefahr, kulturelle Prägungen von Interaktion aus dem Blick zu verlieren. Und die Interpretative Soziolinguistik fokussiert sich auf lokale Missverständnisse, die teilweise zu stark reduziert werden auf non- und paraverbale Kontextualisierungshinweise.

Grundlegender ist die Kritik in Bezug auf die Fokussierung auf Missverständnisse und Differenzen in diesen Studien. Seit seiner Begründung hat sich der Forschungszweig der interkulturellen Kommunikation vor allem auf die Untersuchung von interkulturellen Missverständnissen konzentriert. Interkulturelle Missverständnisse werden häufig sogar als das Legitimationsobjekt zur wissenschaftlichen Bearbeitung des Phänomens der interkulturellen Kommunikation herangezogen. ${ }^{42}$ Die meisten der oben genannten interkulturellen Studien gehen von der Hypothese des Aufeinandertreffens von kulturellen Entitäten mit kulturspezifischen unterschiedlichen Kommunikationskonventionen in interkulturellen Interaktionen aus, die dann unweigerlich zu Missverständnissen in der Kommunikation führen müssen.

\footnotetext{
40 vgl. Rehbein (1994b), S.84 f.

41 ebd.

42 Busch, Dominic: Der Einfluß situativer Faktoren in interkulturellen Kontaktsituationen. Empirisch dargestellt an Gesprächen polnischer und deutscher Studierender, Stuttgart 2003, S.3
} 
Mittlerweile ist diese Sicht bei einigen Forschern der Erkenntnis gewichen, dass auch die interkulturelle Interaktion von Gemeinsamkeiten geprägt ist, zum einen von Universalien, da sonst Kommunikation über Sprachgrenzen hinweg nicht möglich wäre, zum anderen von Homogenisierungen auf Grund von Globalisierungsprozessen. Man denke hier nur an die Anglifizierung der deutschen Wissenschaftskommunikation.

Des Weiteren wird in der Forschung teilweise stärker betont, dass 1) kulturelle Unterschiede in der Interaktion oft normalisiert werden (z.B. unterschiedliche Telefongesprächseröffnungen im Dänischen und Deutschen);43 oder 2) dass bei Unterschieden spezifische interaktive (nicht interkulturelle!) Kompetenzen automatisch Verwendung finden, mit denen Missverständnisse vermieden werden. ${ }^{44}$

Noch grundlegender ist die Kritik in Bezug auf den in den Studien verwendeten Kulturbegriff. Die meisten der oben dargestellten Studien gehen von einem homogenen Kulturbegriff aus, etwa wenn in der Arbeit von Gumperz das Verhalten DER Briten dem DER Inder und DER Pakistani gegenübergestellt wird. Doch im Zeitalter der Globalisierung stellen wir einen drastisch beschleunigten Prozess kultureller Hybridisierung fest. Er resultiert sowohl aus der extremen Binnendifferenzierung immer komplexer werdender moderner Gesellschaften als auch aus deren stetig sich verzweigenden externen globalen Vernetzungen. Und er dauert an.

Die Binnenheterogenität und Hybridität der indischen Kultur wurde weiter oben ausgeführt. Aber auch in Deutschland sind z.B. von den ehemaligen Zuwanderern eine Million mittlerweile eingebürgert. Deutschland hat Zuwanderer in der ersten, zweiten und dritten Generation. Was also umfasst die Begriffe „Deutschland“ und „Deutscher“, wenn man sie in oben dargestellten Studien als Ausgangspunkt von Untersuchungen zur deutsch-indischen Interaktion wählt? Und in wieweit kann das Interaktionsverhalten der wie auch immer definierten „Deutschen“ „typisch deutsch“ sein, wenn es doch deutlich durch Globalisierungsphänomene geprägt wird, wie z.B. besonders in der Werbe-, Wissenschafts- oder Wirtschaftskommunikation.

Schlussfolgerungen aus diesen ersten Kritikpunkten wären also insofern zu ziehen, als dass man in einer interkulturellen Interaktionsforschung

a) sich spezifischer Methoden und Ansätze bedient, z.B. konkrete interkulturelle Interaktionen untersucht und diese möglichst auch triangulär, mit vielfältigen Methoden, wie teilnehmender Beobachtung, Videoaufzeichnung und Interviews, erforscht;

b) die Fokussierung auf Missverständnisse relativiert und

c) den Studien keinen homogenen Kulturbegriff zugrundelegt und deshalb auch das Forschungsdesign verändert.

\footnotetext{
${ }^{43}$ Rasmussen (2000)

44 Asmuß, Birte (2002): Strukturelle Dissensmarkierungen in interkultureller Kommunikation. Analysen deutschdänischer Verbandlungen, Tübingen 2002
} 


\section{Perspektiven einer interkulturellen Interaktionforschung}

\subsection{Grundlegende Kritikpunkte}

Drei weitere zentrale Kritikpunkte, die mit oben genannten Punkten in engem Zusammenhang stehen, sollen in den folgenden Kapiteln näher ausgeführt werden:

Erstens: Vereinzelt setzt sich in der interkulturellen Kommunikationsforschung die Meinung durch, dass Kultur auch (!) als ein Konstrukt angesehen werden muss, dass erst in der Interaktion geschaffen wird, und das nicht wesenhaft einem Gegenstand innewohnt. (s. Kapitel 4.2)

Zweitens: Immer häufiger wird im Zusammenhang mit dem verwendeten Kulturbegriff - wenn auch nicht innerhalb der linguistischen Forschung, sondern eher der Soziologie - die grundlegende Kritik geäußert, dass viele kulturvergleichende und interkulturelle Studien auf Grund ihres Forschungsdesigns einer Kulturalisierung von Interaktionsverhalten Vorschub leisten. (siehe Kapitel 4.3)

Drittens: Entgegen der in obigen Arbeiten zu Missverständnissen noch immer vorherrschenden Vorstellung, dass die interkulturelle Interaktion nur eine Reproduktion der sprachlichen Konventionen darstellt, die die Interaktanten in der Eigenkultur erworben hätten, wird neuerdings auch darauf hingewiesen, dass diese einen wechselseitigen Aushandlungsprozess darstelle, bei dem neue Interaktionsformen geschaffen würden: eine Interkultur. (siehe Kapitel 4.4)

\subsection{Kultur als Konstrukt und das Forschungsdesign}

Kultur ist, wie oben schon dargestellt, in ihrem Doppelcharakter zu sehen, als sedimentiertes Wissen wie als kommunikatives Konstrukt. Um entsprechend diesem Konstruktionscharakter gerecht zu werden, ist Wimmer zu folgen, ${ }^{45}$ der betont, dass interkulturelle Studien nicht von Setzungen ausgehen dürfen, also die Konstrukte „Kultur“, „Nation“ oder Ethnie“ nicht als Ausgangspunkt ihrer Untersuchungen wählen sollten.

"The ethnic group formation perspective calls for non ethnic units of observation which make it possible to see whether and which ethnic groups and boundaries emerge, are subsequently transformed or dissolved - rather than to assume their existence, relevance and continuity by binding the observational apparatus to such groups and communities". 46

Ausgangspunkt der Analysen sollten entsprechend nach Wimmer Interaktionsräume und Institutionen sein, so etwa im Migrationszusammenhang Stadtteile oder Schulen und in internationalen Kontexten Hochschulen, Unternehmen, Kulturinstitutionen oder Medien in verschiedenen Ländern.

\footnotetext{
45 Wimmer, Andreas: How (not) to think about ethnicity in immigrant societies: A boundary making perspective, Working Paper No.44, University of Oxford 2007

46 ebd., S.26
} 
Werden also Projekte im Migrationskontext geplant, so sollte als Untersuchungsgegenstand nicht „die deutsch-türkische“ oder „die deutsch-russische Interaktion“, sondern z.B. die Institution „Schule“ als Untersuchungsfeld gewählt werden. Sodann werden die Spezifika der Interaktion von autochtonen und allochtonen Mitgliedern der Schülerschaft mit den Lehrenden erarbeitet, dies aber immer unter Einbezug des Kontextes der Institution Schule.

Möglicherweise, aber nicht unbedingt, ergeben sich sodann Ergebnisse, die darauf verweisen, dass Interaktionsspezifika bestimmter kultureller Gruppen existieren, ohne dies jedoch schon im Forschungsdesign vorauszusetzen. Mit einem derartigen Ansatz wird einem „methodologischen Nationalismus“ oder einer „methodologischen Ethnisierung“" in interkulturellen und kulturvergleichenden Studien entgegengewirkt, vor dem insbesondere Wimmer/Glick Schiller ${ }^{47}$ warnen. Damit zusammenhängend ist ein weiterer Aspekt bei der Untersuchung wichtig.

\subsection{Multifaktorielle Einflüsse und das Forschungsdesign}

Nicht nur Interaktanten, auch Forscher tendieren dazu, die situativen und sozialen Ursachen für Missverständnisse in interkulturellen Interaktionen zugunsten von kulturellen Aspekten zu ignorieren. ${ }^{48}$ Entsprechend wurde in den obigen Studien häufig einem „methodischen Kulturalismus“ Folge geleistet. ${ }^{49}$ Um diesen Vorwurf abzuwehren, schränken Forscher anderer Disziplinen (z.B. Sozialwissenschaftler) daher die Reichweite ihrer empirischen Ergebnisse ein, indem sie die Relevanz anderer sozialer Aggregate bei ihren Studien betonen. Eine Analyse des Interaktionsverhalten aller Beteiligten muss dieses zum einen deshalb nun differenziert in Bezug auf ihre Zugehörigkeiten zu unterschiedlichen sozialen Aggregaten, etwa biographischen Eigentümlichkeiten, Schicht, Bildung, Stadt/Land, Gender, Generation, Gruppenzugehörigkeiten und eben der Zugehörigkeit zu Ethnie, Nation oder Kultur untersuchen.

Es bedeutet, dass vergleichende und interkulturelle Analysen immer auf mehreren Ebenen ablaufen müssen, in der Sozialforschung als Mehrebenenanalyse bekannt. ${ }^{50}$ Allgemein ausgedrückt werden in einer solchen Mehrebenenanalyse die zu betrachtenden sozialen Aggregate zusätzlich jeweils einzeln einer Analyse unterzogen, die sich auf Aggregate einer zweiten oder dritten Ebene beziehen. Dadurch

\footnotetext{
47 Wimmer, Andreas/Glick Schiller, Nina: Methodological nationalism and the study of migration: Beyond nation-state building, -in: International Migration Review, 37, 3, 2002, S.576-610 und S.579, http://edoc.mpg.de/28957

48 Busch (2003), S.87; vgl. Tzanne, Angeliki: Talking at Cross-Purposes. The Dynamics of Miscommunication, Amsterdam-Philadelphia 2000; Földes, Csaba: Interkulturelle Kommunikation: Positionen zu Forschungsfragen, Methoden und Perspektiven, Wien 2007

${ }^{49}$ Nohl, Arnd-Michael: Komparative Analyse als qualitative Forschungsstrategie, -in: Straub, Jürgen/Weidemann, Arne/Weidemann, Doris (Hrsg.): Handbuch interkulturelle Kommunikation und Kompeten₹, Stuttgart-Weimar 2007, S.399

${ }^{50} \mathrm{ebd}$.
} 
wird die Binnenheterogenität empirisch evident. Dieses Verfahren lässt sich problemlos auf die interkulturelle Interaktionsforschung übertragen.

Einem methodischen Kulturalismus wurde in den oben dargestellten Studien zur interkulturellen Kommunikation aber auch deshalb Vorschub geleistet, weil über diese sozialen Faktoren hinaus auch die weiteren situativen Faktoren der Interaktion, die kommunkativ-pragmatischen Einflussfaktoren, bei der Interpretation von Missverständnissen in der interkulturellen Interaktion häufig unzulässig vernachlässigt wurden. Entsprechend müssen neben den oben aufgeführten sozialen Bezugspunkten auch kommunikativ-pragmatische Faktoren bei der Interpretation eines Interaktionsverhaltens mit in Betracht gezogen werden: so z.B. das soziale Verhältnis der Gesprächspartner (und seine Wahrnehmung, etwa LehrerSchülerverhältnis), der Grad der Öffentlichkeit (privat oder öffentlich), der Bekanntheitsgrad der Gesprächspartner (von vertraut bis unbekannt), die Handlungsdimension des Gesprächs (direktiv, narrativ, diskursiv (alläglich, wissenschaftlich)), Ort, Zeit, Raum ... usw.

Die kommunikative Situation wird auch durch vier weitere wichtige Dimensionen mitgeprägt, die in die Situation der Interaktion eingebracht werden: ${ }^{51}$ die Erwartungshaltungen der Interaktanten durch medienvermittelte Fremdbilder (z.B. „direkter Chinese in Deutschland"), Kollektiverfahrungen mit der Kontaktgruppe (z.B. Deutsche und Polen; Europäer und Afrikaner) und Machtasymmetrien (z.B bei Beratungsgesprächen mit Zuwanderern). Gerade Machtasymmetrien z.B. führen dazu, dass Missverständnisse nicht - wie etwa bei interkulturellen Alltagsgesprächen - mit metakommunikativen Reparaturmechanismen ohne Folgen behoben bzw. normalisiert werden, sondern dass Kommunikationsstörungen eher den Zuwanderern angelastet werden und zu Diskriminierungen führen. ${ }^{52}$

Hier gilt es, ein für Forschungsprojekte operationalisierbares Modell aller für interkulturelle Interaktionssituationen relevanten objektiven und subjektiven Faktoren $^{53}$ und ihrer möglichen Interdependenzen zu erarbeiten: etwa als objektive Faktoren Ort, Zeit und Raum, als subjektive die Erwartungshaltungen der Interaktanten etc. Ein derartiges Modell aller relevanten Faktoren stellt bisher noch ein Forschungsdesiderat dar.

\subsection{Interkulturelle Kommunikation, Missverständnisse und die Interkultur}

Wie oben schon angedeutet, gehen zahlreiche Forscher davon aus, dass die in der Eigenkultur erworbenen Handlungsmuster direkt auf die Interaktion in interkulturellen Situationen übertragen werden und es dadurch zu Missverständnissen in der Interaktion kommt. Insgesamt richten mittlerweile aber ausgewählte Forscher ihr

\footnotetext{
51 Auernheimer, Georg: Einfübrung in die Interkulturelle Pädagogik, Darmstadt ${ }^{4} 2006$, S.14

52 vgl. ebd., S.14,151

${ }^{53}$ vgl. Esser, H.: Die Definition der Situation, -in: Kölner Zeitschrift für Soziologie und Sozialpsychologie, 48, 1996, S.1-34
} 
Augenmerk mehr und mehr auf die Interaktionsdynamik interkultureller Prozesse. ${ }^{54}$ Diese werden nicht mehr - wie früher - als ein „Aufeinandertreffen verschiedener Kultur- und Kommunikationsformen“, sondern als situationsspezifisches Aushandeln verstanden, in dem die Kommunikationspartner signifikant anders reagieren als in Kommunikationssituationen mit Vertretern aus der eigenen Kultur und entsprechend zu neuen hybriden Formen sprachlichen Handelns kommen. In der interkulturellen Forschung ist hierfür der Begriff „Interkultur“ geprägt worden, der eine kommunikative „Zwischenkultur“ bezeichnen soll, die durch den Kulturkontakt konstruiert wird" ". ${ }^{55}$ Dabei entstehen Diskursformen, die in ihrer Eigenart nicht mehr rückführbar sind auf „typisch deutsche“ oder „typisch indische“ Verhaltensweisen. ${ }^{56}$ Blickt man zurück auf die oben dargestellte Forschung zu interkulturellen Missverständnissen, so wird dieser Prozesshaftigkeit und diesem Aushandlungsprozess von Interaktanten in der interkulturellen Interaktion nur wenig Aufmerksamkeit geschenkt.

Obwohl diese Sichtweise auf die interkulturelle Interaktion einen wichtigen Aspekt darstellt, muss aber kritisch eingewendet werden, dass dieser geschilderte Aushandlungsprozess von neuen Interaktionsstrukturen von den Interaktanten auch gewollt sein muss. Die Schaffung einer Interkultur erfordert zugleich das Einverständnis, die Kooperationsbereitschaft und die Kompetenz aller an der Situation Beteiligten. ${ }^{57}$ Eine derartige Kompetenz zur Schaffung einer Interkultur (als Neuem) kann nicht bei allen Menschen und in allen Situationen vorausgesetzt werden. Sie muss gewollt und aufgrund von Machtverhältnissen auch möglich sein. Ten Thije differenziert denn auch in seinen späteren Arbeiten ${ }^{58}$ mehrere Möglichkeiten der Prägung des Sprach- und Kulturkontakts, von der Entstehung von Missverständnissen über Adaptionen bis hin zur Interkultur. Dabei bezieht sich dieses Sprach- und Kulturkontakt-Modell wiederum sehr stark auf homogene kulturelle Entitäten.

Mögliche Folgen des Sprach- und Kulturkontakts

$\begin{array}{ll}\text { Folge 1: } & \mathrm{B} A=0 \\ \text { Folge 2: } & \mathrm{B}=\mathrm{A}=\mathrm{A} \\ \text { Folge 3: } & \mathrm{B}-\mathrm{A}=\mathrm{B} \\ \text { Folge 4: } & \mathrm{B} A=\mathrm{A}+\mathrm{B} \\ \text { Folge 5: } & \mathrm{B} \mathrm{A}=\mathrm{C}\end{array}$

Im ersten Fall stoßen nach ten Thije ${ }^{59}$ verschiedene Problemlösungspotentiale aufeinander, wobei sich Störungen und Missverständnisse ergeben, unter dieser

\footnotetext{
${ }^{54}$ Koole/ten Thije (1994); Bührig, Kristin/ten Thije, Jan D. (Hrsg.): Beyond misunderstanding, the linguistic reconstruction of intercultural discourse. Amsterdam 2006; auch Rehbein (2006); Rehbein (2007)

55 Müller-Jacquier, Bernd: Interkulturelle Kommunikation und Fremdsprachendidaktik. Ein Studienbrief zum Fernstudienprojekt „Fremdsprachen im Grundstudium“, Koblenz 1999, S.37

56 ten Thije (2002)

57 Busch (2003), S.28

58 ten Thije (2002), S.67

59 ebd.
} 
Perspektive haben die bisherigen Forschungen interkulturelle Interaktion vor allem betrachtet. Im zweiten Fall adaptieren die Interaktanten der einen Kultur die Interaktionskonventionen der anderen Kultur (etwa Zuwanderer, die sich assimilieren), im dritten geschieht es umgekehrt (etwa deutsche Unternehmer, die sich aus Erfolgsinteresse an chinesische Konventionen der Gesprächsführung anpassen wollen), im vierten nutzen die Interaktanten abwechselnd verschiedene Potentiale und im fünften entwickeln sich diskursive Strukturen, die nicht auf die beiden in Kontakt stehenden Kulturen zurückzuführen sind. Ten Thije geht damit davon aus, dass die Interkultur nur eine der Folgen des Sprach- und Kulturkontakts darstellt. ${ }^{60}$ Auch wenn dieses Modell wiederum sehr stark von homogenen Entitäten ausgeht, könnte man es als Ausgangspunkt weiterer Überlegungen zur Entwicklung eines theoretischen Modells nutzen, das versucht, die Regularitäten des Kulturkontakts zu erarbeiten. Hier seien nur erste Überlegungen zur Modifizierung dieses Modells aufgeführt, indem z.B. Kulturen als hybrid und binnendifferenziert dargestellt werden; die Prozesse als auf unterschiedlichen sprachlichen Ebenen auch unterschiedlich ablaufend präsentiert werden (Adaption im Wortschatz, Missverständnisse in der Pragmatik) etc. Die Entwicklung eines derartigen Modells stellt ein weiteres Forschungsdesiderat dar.

\section{Zusammenfassung: Perspektiven interkultureller Interaktionsforschung}

Interkulturelle Interaktionsforschung muss von einem differenzierten, nicht homogenen Kulturbegriff ausgehen. Dabei ist aber trotz aller drastisch voranschreitender Hybridisierungs- und Globalisierungsprozesse zu bedenken, dass das Konzept einer Transkulturalität, d.h. der kompletten Auflösung der konzeptuellen Grenzen von Einzelkulturen, noch vielfach über den Status quo, der in der Welt anzutreffen ist, hinausgeht. Abdrücke monokultureller, wenn auch deutlich binnendifferenzierter Formationen sind überall noch sichtbar. Insofern können mittels der dargestellten Methoden, der Wahl von Interaktionsräumen als Ausgangspunkt, der Mehrebenenanalyse und des Einbezugs aller relevanten situativen Faktoren am Ende sehr wohl kulturspezifische Verhaltensweisen spezifischer Gruppierungen zum Vorschein kommen. Sie können das Ergebnis des Forschungsprozesses sein, sie dürfen nicht ihren Ausgangspunkt bilden.

Interkulturelle Interaktionsforschung sollte zudem dem Konstruktionscharakter von Kultur gerecht werden, ohne aus dem Blick zu verlieren, dass derartige Konstruktionen wirkungsmächtig werden, und reale, differenzierte ethnische und nationale Besonderheiten und Grenzen herstellen können.

${ }^{60}$ ebd., S.67 
Und nicht zuletzt sollte die Forschung nicht aus dem Blick verlieren, dass die Regeln interkultureller Interaktionen von Kommunikationsstörungen über Adaptionen bis hin zu Konzepten von Interkultur reichen können.

Erst mit einem derartigen Ansatz lassen sich deutsch-indische Interaktionsweisen reflektiert und differenziert analysieren, und erst mit derartig gewonnenen Forschungsergebnissen lassen sich auch wirksame interkulturelle Trainings für die deutsch-indische Zusammenarbeit entwickeln.

\section{Literatur}

Antor, Heinz (Hrsg.) (2006a): Inter-und Transkulturelle Studien. Theoretische Grundlagen und interdisziplinäre Praxis, Heidelberg: Universitätsverlag 2006

Antor, Heinz (2006b): Multikulturalismus, Interkulturalität und Transkulturalität. Perspektiven für interdisziplinäre Forschung und Lehre, -in: Antor, Heinz (Hrsg.): Inter-und Transkulturelle Studien. Theoretische Grundlagen und interdisziplinäre Praxis, Heidelberg: Universitätsverlag 2006, S.25-39

Asmuß, Birte: Strukturelle Dissensmarkierungen in interkultureller Kommunikation. Analysen deutsch-dänischer Verbandlungen, Tübingen: Niemeyer 2002 (Linguistische Berichte; 452)

Auernheimer, Georg: Einführung in die Interkulturelle Pädagogik, Darmstadt: Wissenschaftliche Buchgesellschaft ${ }^{4} 2006$

Bachmann-Medick, Doris: Cultural Turns. Neuorientierungen in den Kulturwissenschaften, Reinbek b. Hamburg: Rowohlt 2006 (rowohlts enzyklopädie)

Bhatti, Anil: Kulturdiskussion in Indien, -in: Ensyyklopädie vielsprachiger Kulturwissenschaften 2000 http://www.inst.at/ausstellung/enzy/kultur/indien_bhatti.htm.

Borden, G. A.: Cultural Orientation. An approach to understanding intercultural communication, Englewood Cliffs: Prentice Hall 1991

Bührig, Kristin/ten Thije, Jan D. (Hrsg.): Beyond misunderstanding, the linguistic reconstruction of intercultural discourse, Amsterdam: Benjamins 2006

Busch, Dominic: Der Einfluß situativer Faktoren in interkulturellen Kontaktsituationen. Empirisch dargestellt an Gesprächen polnischer und deutscher Studierender, Stuttgart: ibidem 2003

Casper-Hehne, Hiltraud: Interkulturelle Kommunikation aus sprachwissenschaftlicher Perspektive: Kritische Reflektion der Forschungsansätze und Forschungsergebnisse im deutsch-indischen Zusammenhang, -in: Casper-Hehne, Hiltraud/Gupte, Niteen (Hrsg.): 
Kommunikation über Grenzen. Ansätze zur interkulturellen Verständigung, Göttingen: Universitätsverlag Göttingen 2010

Casper-Hehne, Hiltraud: Russisch-deutsche Interaktion in der Schule: Empirische Untersuchungen zu Linguistik und Didaktik interkultureller

Unterrichtskommunikation, -in: Zielsprache Deutsch, 3 (In Vorbereitung)

Casper-Hehne, Hiltraud: Interkulturelle Wissenschaftskommunikation. Zu

Linguistik und Didaktik von Seminarkommunikation an einem deutschchinesischen Fallbeispiel, -in: Vorstand des Arbeitskreises für interkulturelle Germanistik in China (Hrsg.): Deutsch-Chinesisches Forum interkultureller Bildung. Band 1: Wissenschaft im internationalen Kontext, München: iudicium 2007, S.145158

Casper-Hehne, Hiltraud: Interkulturelle Alltagskommunikation zwischen anglophonen USamerikanischen FremdsprachenlernerInnen und deutschen MuttersprachlerInnen. Zu narrativen, diskursiven und direkten Gesprächen, Tübingen: Niemeyer 2006 (Reihe Germanistische Linguistik; 265)

Casper-Hehne, Hiltraud (2005a): Wissenschaftskommunikation kontrastiv. Zum Stand der Forschung, -in: Riemer, Claudia u.a. (Hrsg.): Deutsch als Fremdsprache. Sprachen lebren - Sprachen lernen, Regensburg: Fachverband Deutsch als Fremdsprache 2005 (Dokumentationen des FaDaF)

Casper-Hehne, Hiltraud (2005b): Handlungs- und Beziehungsaspekte in der Wissenschaftskommunikation ausländischer Studierender. Probleme Perspektiven, -in: Casper-Hehne, Hiltraud/Ehlich, Konrad (Hrsg.): Kommunikation in der Wissenschaft, Regensburg: Fachverband Deutsch als Fremdsprache, 2005, S.57-73 (Materialien Deutsch als Fremdsprache; 69)

Casper-Hehne, Hiltraud (2005c): Perspektiven einer kontrastiven Erforschung der Wissenschaftskommunikation: am Beispiel deutscher und anglophoner Transkripte und Gespräche, -in: DAAD (Hrsg.): Germanistentreffen DeutschlandGroßbritannien - Irland, 30.09.-3.10.2004, Dresden: Dokumentation der Tagungsbeiträge 2005, S.207-217

Esser, H.: Die Definition der Situation, -in: Kölner Zeitschrift für Soziologie und Sozialpsychologie, 48, 1996, S.1-34

Földes, Csaba: Interkulturelle Kommunikation: Positionen zu Forschungsfragen, Methoden und Perspektiven, Wien: Universitätsverlag Veszprém-Edition Praesens Wien 2007 (Studia Germanica Universitatis Vesprimiensis, Supplement 7)

Földes, Csaba: Interkulturelle Linguistik. Vorüberlegungen zu Konzepten, Problemen und Desiderata, Wien: Universitätsverlag Veszprém-Edition Praesens Wien 2005 (Studia Germanica Universitatis Vesprimiensis, Supplement 1) 
Ganeshan, Vridhagiri: Mit dem deutschen Kanon auf die indischen Studenten schießen? Deutschsprachige Texte und indische Wahrnehmungsperspektiven, in: Auer, Michaela/Müller, Ulrich (Hrsg.): Kanon und Text in interkulturellen Perspektiven: „Andere Texte anders lesen“, 4. Internationaler Kongreß der „Gesellschaft für Interkulturelle Germanistik“ und der Universität Salzburg (Kaprun 23. - 27.9.1998), Stuttgart: Hans-Dietrich Heinz 2001, S.327-333 (Publikationen der Gesellschaft für Interkulturelle Germanistik; 7) (Stuttgarter Arbeiten zur Germanistik; 401)

Ganeshan, Vridhagiri: Intercultural Misunderstanding between Indians and Germans, -in: Harden, Theo/Witte, Arnd/Riou, Jeanne (Hrsg.): The Notion of Intercultural Understanding in the Context of German as a Foreign Language, Bern: Peter Lang 2000 (German Linguistic and Cultural Studies, V)

Geertz, Clifford: Dichte Beschreibung: Beiträge zum Verstehen kultureller Systeme, Frankfurt/M: Suhrkamp 1987

Gulyanska, Maya: Ost-West-Unterschiede in wirtschaftsrelevanten Teilgebieten der Persönlichkeit. Veränderung und Veränderbarkeit von Schlüsselqualifikationen bei osteuropäischen IT-Fachkeräften in Deutschland, Diss. Bochum 2005 http: / wwwbrs.ub.ruhr-uni-bochum.de/netahtml/HSS/Diss/GulyanskaMaya/diss.pdf

Gupte, Niteen/Müller-Gupte, Anke: German Perception of the Indian Workplace. A Study in Intercultural Understanding - Indische Arbeitswelt aus deutscher Sicht. Eine Studie in Interkultureller Verständigung, Pune: University of Pune 2008 (CSS Occasional Papers Series 2007-2008)

Hall, Edward T./Hall, Mildred: Verborgene Signale. Studien zur internationalen Kommunikation. Über den Umgang mit Amerikanern, Santa Fe-Hamburg: Gruner und Jahr 1983

Hofstede, Geert: Lokales Denken, globales Handeln. Interkulturelle Zusammenarbeit und globales Management, München ${ }^{42009}$, zit. wird ${ }^{32} 2006$, (Beck Wirtschaftsberater im dtv)

Hofstede, Geert: Interkulturelle Zusammenarbeit. Kulturen - Organisationen Management, Wiesbaden: Gabler 1993

Hofstede, Geert: Cultures and Organisations. Software of the mind, London: McgrawHill 1991

House, Juliane: Contrastive discourse analysis and universals in language use, -in: Papers and Studies in Contrastive Linguistics, 20, 1985, S.5-14

House, Juliane (1982a): Opening and closing phases in English and German dialogues, -in: Grazer Linguistische Studien, 16, 1982, S.52-82

House, Juliane (1982b): Conversational strategies in German and English dialogues, -in: Nickel, Gerhard/Nehls, Dietrich (Hrsg.): Error analysis, contrastive 
linguistics and second language learning, Heidelberg: Julius Groos 1982, S.136-150 (IRAL - Sonderband. Heidelberg)

Koole, Tom/ten Thije, Jan: The Construction of Intercultural Discourse: Team Discussions of Educational Advisers, -in: Journal of technical writing and communication, 25, 2, 1995, S.225-228

Koole, Tom/ten Thije, Jan (1994a): The Construction of Intercultural Discourse: Team Discussions of Educational Advisers, Amsterdam-Atlanta: Editions Rodopi 1994 (Utrecht Studies in Language and Communication; 2)

Koole, Tom/ten Thije, Jan (1994b): Der interkulturelle Diskurs von Teambesprechungen. Zu einer Pragmatik der Mehrsprachigkeit, -in: Brünner, Gisela/Graefen, Gabriele (Hrsg.): Texte und Diskurse. Methoden und Forschungsergebnisse der Funktionalen Pragmatik, Opladen: Westdeutscher Verlag 1994, S.412-434

Kotthoff, Helga: Kultur(en) im Gespräch, -in: Kotthoff, Helga (Hrsg.): Kultur(en) im Gespräch, Tübingen: Günter Narr 2002, S.7-22 (Literatur und Anthropologie; 14)

Kotthoff, Helga (Hrsg.): Kultur(en) im Gespräch, Tübingen: Günter Narr 2002 (Literatur und Anthropologie; 14)

Kotthoff, Helga: Pro und Kontra in der Fremdsprache. Pragmatische Defizite in interkulturellen Argumentationen, Frankfurt/M-Bern-New York-Paris: Peter Lang 1989

Krewer, Bernd: Kulturstandards als Mittel der Selbst- und Fremdreflexion in interkulturellen Begegnungen, -in: Thomas, Alexander (Hrsg.): Psychologie interkulturellen Handelns, Göttingen: Hogrefe 1996, S.110-35 http://www.krewerconsult.de/docs/Kulturstandards $\% 20$ als $\% 20$ Mittel $\% 20 d e r$ $\% 20$ Selbst-\%20und $\% 20$ Fremdreflexion.pdf.

Kübert, Sabine: Mit Hilfe der Trainingsmethode „Culture Assimilator" interkulturelle Unterschiede verstehen. Ansätze für Indien, Stuttgart: Hochschule der Medien 2006

Kuhn, Elisabeth D.: Gender and Authority. Classroom Diplomacy at German and American Universities, Tübingen: Günter Narr 1983 (Tübinger Beiträge zur Linguistik; 373)

Liang, Yong: Höflichkeit als xenologisches Thema der interkulturellen Kommunikation, -in: Wierlacher, Alois (Hrsg.): Kulturthema Kommunikation. Konzepte - Inhalte - Funktionen, Möhnesee: Residence Verlag 2000, S.233-257

Liang, Yong: Höflichkeit im Chinesischen. Geschichte - Konzepte - Handlungsmuster, München: iudicium 1998 
McSweeney, Brendan: Hofstede's Model of National Cultural Differences and Their Consequences: A Triumph of Faith - A Failure of Analysis, -in: Human Relations, Jg.55, 2002, H.1, S.89-119

Mitterer, Katrin/Mimler, Rosemarie/Thomas, Alexander: Beruflich in Indien. Trainingsprogramm für Manager, Fach- und Führungskräfte, Göttingen: Vandenhoeck \& Ruprecht 2006 (Handlungskompetenz im Ausland)

Müller-Jacquier, Bernd: Interkulturelle Kommunikation und Fremdsprachendidaktik. Ein Studienbrief zum Fernstudienprojekt „Fremdsprachen im Grundstudium“, Koblenz: Universität Koblenz-Landau 1999

Muikku-Werner, Pirkko: Sind die Finnen Barbaren? Kontrastive Analyse deutscher und finnischer Abschwächungstechnik, -in: Reuter, Ewald (Hrsg.): Wege der Erforschung deutsch-finnischer Kulturunterschiede in der Wirtschaftskommunikation, Tampere: Tampereen Yliopisto Jäljennepalvelu 1992, S.75-100 (Publikationsreihe des Sprachenzentrums der Universität Tampere; 3/1991)

Neidert, Christina: Imagearbeit in Fernsehserien - kontrastiv. Vergleich der Muster und Sequenzen in amerikanischen und deutschen Seriendialogen, Frankfurt/M: Peter Lang 2001 (Europäische Hochschulschriften; XXI, 234)

Niehaus-Lohberg, Erika/Herrlitz, Wolfgang: Verständigung zwischen Niederländern und Deutschen: Ein Beitrag zur Analyse der interkulturellen Kommunikation zwischen Unternehmen, -in: Bungarten, Theo (Hrsg.): Sprache und Kultur in der interkulturellen Marketingkommunikation, Tostedt: Attikon 1994, S.143-166 (Beiträge zur Wirtschaftskommunikation; 11)

Nohl, Arnd-Michael: Komparative Analyse als qualitative Forschungsstrategie, -in: Straub, Jürgen/Weidemann, Arne/Weidemann, Doris (Hrsg.): Handbuch interkulturelle Kommunikation und Kompeten₹, Stuttgart-Weimar: J.B. Metzler 2007, S.391-403

Nuopponen, Anita/Harakka, Terttu/Tatje, Rolf (Hrsg.): Interkulturelle Wirtschaftskommunikation. Forschungsobjekte und Methoden, Vaasa: Tarja Salo 2002

Rasmussen, Gitte: Zur Bedeutung kultureller Unterschiede in interlingualen interkulturellen Gesprächen. Eine Mikroanalyse deutschsprachiger Interaktionen zwischen Franzosen und Dänen und zwischen Deutschen und Dänen, München: iudicium 2000 (Reihe interkulturelle Kommunikation; Bd. 5)

Rathmeyr, Renate: Höflichkeit als kulturspezifisches Konzept. Russisch im Vergleich, -in: Ohnheiser, Ingeborg (Hrsg.): Wechselbeziehungen zwischen slawischen Sprachen, Literaturen und Kulturen in Vergangenheit und Gegenwart, Innsbruck 1996, S.174-185 (Innsbrucker Beiträge zur Kulturwissenschaft. Slavica Aenipontana; 4) 
Redder, Angelika (Hrsg.) (1994a): Diskursanalysen in praktischer Absicht, Oldenburg 1994 (Osnabrücker Beiträge zur Sprachtheorie. OBST; 49)

Redder, Angelika (1994b): „Bergungsunternehmen“ - Prozeduren des Malfeldes beim Erzählen, -in: Brünner, Gisela/Graefen, Gabriele (Hrsg.): Texte und Diskurse. Methoden und Forschungsergebnisse der Funktionalen Pragmatik, Opladen: Westdeutscher Verlag 1994, S.238-264

Redder, Angelika (Hrsg.): Kommunikation in Institutionen, Bremen 1983 (Osnabrücker Beiträge zur Sprachtheorie. OBST; 24)

Redder, Angelika/Rehbein, Jochen: Arbeiten zur interkulturellen Kommunikation, Bremen 1987 (Osnabrücker Beiträge zur Sprachtheorie. OBST; 38)

Rehbein, Jochen: Sprachpragmatische Ansätze, -in: Straub, Jürgen/Weidemann, Arne/Weidemann, Doris (Hrsg.): Handbuch interkulturelle Kommunikation und Kompeten₹, Stuttgart-Weimar: J.B. Metzler 2007, S.131-144

Rehbein, Jochen: The cultural apparatus. Thoughts on the relationship between language, culture and society, -in: Bührig, Kristin/ten Thije, Jan D. (Hrsg.): Beyond misunderstanding, the linguistic reconstruction of intercultural discourse, Amsterdam: Benjamins 2006, S.43-96

Rehbein, Jochen (1994a): Widerstreit. Semiprofessionelle Rede in der interkulturellen Arzt-Patienten-Kommunikation, -in: Klein, Wolfgang/Dittmar, Norbert (Hrsg.): Interkulturelle Kommunikation, Göttingen 1994, S.123-151 (Zeitschrift für Literaturwissenschaft und Linguistik, H. 93)

Rehbein, Jochen (1994b): Rejective proposals: Semi-professional speech and clients' varieties in intercultural doctor-patient communication, -in: Multilingua. Journal of Cross-cultural and Interlanguage Communication, 13, 1/2, 1994, S.83-130

Rehbein, Jochen: Institutioneller Ablauf und interkulturelle Mißverständnisse in der Allgemeinpraxis. Diskursanalytische Aspekte der Arzt-PatientKommunikation, -in: Curare, 9, 1986, S.297-328

Schilling, Andrea: Bewerbungsgespräche in der eigenen und fremden Sprache Deutsch. Empirische Analysen, Frankfurt/M-Berlin-Bern-Bruxelles-New York: Peter Lang 2001 (Arbeiten zur Sprachanalyse; Bd. 40)

Schroll-Machl, Sylvia: Deutschland, -in: Thomas, Alexander/Kammhuber, Stefan/Schroll-Machl, Sylvia (Hrsg.): Handbuch Interkulturelle Kommunikation und Kooperation. Bd. 2: Länder und Kulturen und interkulturelle Berufstätigkeit, Göttingen: Vandenhoeck \& Ruprecht 2003, S.72-89

Srinivasan, Anuradha: Das Fremdbild, das Selbstbild und das Metabild - die imaginären und realen Differenzen deutsch-indischer beruflicher Interaktionen. Ergebnisse des Projekts INTERMAN, Abstract, 2007 
http://www.uta.fi/laitokset/kielet/yht/tutkimus/GIG-

Tagung2007/abstracts.pdf

Stolt, Birgit: Kulturbarrieren als Verständigungsproblem, -in: Reuter, Ewald (Hrsg.): Wege der Erforschung deutsch-finnischer Kulturunterschiede in der Wirtschaftskommunikation, Tampere: Universität Tampere 1992, S.28-46

(Publikationsreihe des Sprachenzentrums der Universität Tampere; 3/1991)

Straub, Jürgen/Weidemann, Arne/Weidemann, Doris (Hrsg.): Handbuch für Interkulturelle Kommunikation und Kompetenz: Grundbegriffe - Theorien Anwendungsfelder, Stuttgart-Weimar: Metzler 2007

ten Thije, Jan D.: Stufen des Verstehens bei der Interpretation von interkulturellen Diskursen, -in: Kotthoff, Helga (Hrsg.): Kultur(en) im Gespräch, Tübingen: Günter Narr 2002, S.61-98 (Literatur und Anthropologie; 14)

Tiittula, Liisa (2001a): Argumentationsstile in deutschen und finnischen Fernsehsendungen, -in: Jakobs, Eva-Maria/Rothkegel, Annely (Hrsg.): Perspektiven auf Stil, Tübingen: Niemeyer 2001, S.205-227

Tiittula, Liisa (2001b): Normen und Normvorstellungen in deutschen und finnischen Fernsehdiskussionen, -in: Breuer, Ulrich/Korhonen, Jarmo Antero (Hrsg.): Mediensprache - Medienkritik, Frankfurt/M: Peter Lang 2001, S.253-271 (Finnische Beiträge zur Germanistik; Bd. 4)

Tiittula, Liisa (2001c): Adressierung in deutschen und finnischen öffentlichen Diskussionen, -in: Lüger, Hans-Helmut (Hrsg.): Höflichkeitsstile, Frankfurt/M: Peter Lang 2001, S.277-294 (Cross cultural communication; Vol. 7)

Thomas, Alexander: Kultur und Kulturstandards, -in: Thomas, Alexander/Kammhuber, Stefan/Schroll-Machl, Sylvia (Hrsg.): Handbuch Interkulturelle Kommunikation und Kooperation. Bd. 1: Grundlagen und Praxisfelder, Göttingen: Vandenhoeck \& Ruprecht 2003, S.19-31

Thomas, Alexander/Kammhuber, Stefan/Schroll-Machl, Sylvia (Hrsg.) (2003a): Handbuch Interkulturelle Kommunikation und Kooperation. Bd. 1: Grundlagen und Praxisfelder, Göttingen: Vandenhoeck \& Ruprecht 2003

Thomas, Alexander/Kammhuber, Stefan/Schroll-Machl, Sylvia (Hrsg.) (2003b): Handbuch Interkulturelle Kommunikation und Kooperation. Bd. 2: Länder und Kulturen und interkulturelle Berufstätigkeit, Göttingen: Vandenhoeck \& Ruprecht 2003

Tzanne, Angeliki: Talking at Cross-Purposes. The Dynamics of Miscommunication, Amsterdam-Philadelphia: Benjamins 2000

Wimmer, Andreas: How (not) to think about ethnicity in immigrant societies: A boundary making perspective, Working Paper No. 44, University of Oxford 2007 (ESRC Centre on Migration, Policy and Society) 



\title{
Zugang zur fremden Kultur durch Autobiographien und Familiengeschichten
}

\author{
Sunanda Mahajan
}

Es gibt in der gesamtdeutschen Geschichte Phasen, mit denen sich Deutsche nur mit Schwierigkeiten beschäftigen. Einmal ist das die Nazi-Diktatur und das andere Mal die kommunistische Diktatur, die in der Deutschen Demokratischen Republik 40 Jahre lang existierte. Selbstverständlich sind sie nicht mit einander zu vergleichen. Zahlreiche Autoren haben die Nazi-Zeit und vor allem den Holocaust thematisiert und in mehreren Büchern und anderen Schriften ist die „Schuldfrage“, sagt man, ausdiskutiert worden. Und nach der Wende und Wiedervereinigung erschien eine Fülle von Büchern, die sich mit den Fragen der DDR-Zeit auseinandersetzen. Ebenso sind mehrere Filme entstanden wie Das Leben der Anderen, die die Staatssicherheit und das Leben einfacher Menschen in der DDR zum Thema machen.

Aus meiner Lektüre der Autobiographien und Familiengeschichten möchte ich hier zwei Texte anführen. Mich interessiert hier vor allem der Umgang der Autorinnen mit der Zeitgeschichte, die sie in ihren Büchern rekonstruieren. Meine Lesart der Bücher ist natürlich bedingt durch die Tatsache, dass ich diese als Inderin gelesen habe. Die Beschäftigung mit von Frauen verfassten Familiengeschichten begann für mich aus einem interkulturellen Anlass. Ausgehend von der Lektüre der Marathi-Frauenautobiographien in den letzten 30 Jahren suchte ich nach dem Selbstbild und Selbstbewusstsein der deutschen Frauen in ihren Lebensgeschichten. Aber die mir verfügbaren deutschen Bücher waren eher von Frauen verfasste 
Familiengeschichten, in denen sie sich nicht über sich selbst äußerten, sondern über ihre Mütter und Großmütter.

Autobiographien sind Rekonstruktion des eigenen Lebens, sie sind Erinnerungsarbeit. Peter Sloterdijk äußert sich über das Wesen der Gattung Autobiographie wie folgt:

„Dieses historisch-sozial individualisierte Ich organisiert schreibend seine Erfahrung zur Literatur, indem es sie erzählerisch ausarbeitet, reflektorisch deutet, sie im Zusammenhang mit durchgreifenden biographischen Patterns zu einer Synthese ordnet, sie auswählt, pointiert, stilisiert, für sie alle eine sprachliche Instrumentierung sucht und so durch Schreiben und Schweigen, durch Bekenntnis und Lüge ein Lebensbild produziert, das für andere zugänglich wird". 1

Er beschreibt also Autobiographie als „durch Schreiben und Schweigen, durch Bekenntnis und Lüge" produziertes Lebensbild. Man formuliert Bekenntnis oder Lüge. Beide Momente sind dort präsent. Das Ich verfügt über einen Überblick über das eigene Leben in seiner Gesamtheit; im Unterschied zu einem Tagebuch, das kontinuierlich geschrieben wird, wobei das schreibende Ich nur das erlebte, gelebte Moment zu der Zeit der Niederschrift schriftlich formuliert. Familiengeschichten, die als mündlich tradiertes Narrativ in vielen Familien von einer Generation zur anderen weitergegeben werden, können aber auch von einem Familienmitglied schriftlich festgehalten werden. Das schreibende Ich hat die Position des Erzählers, der die Geschichte beobachtet und rekonstruierend niederschreibt. Natürlich aus seiner Perspektive. Es könnte möglich sein, dass wenn von einem anderen Mitglied verfasst, die Geschichte der Familie anders verstanden und anders geschrieben wird. Familiengeschichten sind daher genau so subjektiv und individuell wie Autobiographien. Gleichzeitig kann das erzählende Ich dem Erzählten gegenüber eine gewisse Distanz einnehmen, weil sie nicht nur seine Selbstgeschichte ist.

Familiengeschichten, die ich in der letzten Zeit gelesen habe, erschienen mir als individualistische Miniaturen der Geschichte, die das kollektive Schicksal einer Familie im größeren sozialen historischen Rahmen darstellen. Spannend ist dabei zu beobachten, wie die historische Wirklichkeit Familien beeinflusste, und wie das erzählende Ich die gemeinsame Geschichte der Familie bearbeitete.

„Familiengeschichten haben offene und verborgene Gesichter, sie werden auf laute und verschwiegene Weise von Generation zu Generation weitergegeben“", so liest man auf dem Klappentext des Buches Stille Post von Christina von Braun. ${ }^{2}$ Im Prolog ihrer Familiengeschichte schreibt die Autorin, Kulturwissenschaftlerin und Filmemacherin: „Ich will über diese gewaltigen Entladungen von Strom und Wut erzählen, die gelegentlich von meiner Mutter ausgingen...Und ich will von meiner

\footnotetext{
1 Sloterdijk, Peter: Literatur und Organisation von Lebenserfabrung. Autobiographien zwanziger Jabre, München 1978, S.6

2 Braun, Christina von: Stille Post. Eine andere Familiengeschichte, Berlin 2007
} 
Großmutter erzählen, die ich nicht mehr gekannt habe. Sie starb drei Monate, nachdem ich geboren wurde - in Berlin, im Gefängnis“.33 Auf derselben Seite liest man, dass keine Tagebücher, Briefe, Akten, Dokumente von dieser Großmutter mehr vorhanden sind, alles vernichtet und verloren gegangen. Die Autorin fand schließlich in Berliner Archiven ein paar konkrete Hinweise auf das Leben und Leistungen dieser Großmutter. Sie sagt: „Ich bin jedoch zu der Erkenntnis gekommen, daß sich die Erinnerungen manche Menschen auch in Form von Schweigen oder Rätsel festschreiben können."

Die Großmutter mütterlicherseits, Hildegard Margis, war der Anlass für das Buch. Die Autorin beschäftigt sich später in diesem Buch mit dem Leben ihrer Mutter und der Großmutter väterlicherseits, Emmy von Braun. Mit Hilfe der Tagebücher und Briefe und anderer Familiendokumente vertieft sie sich mit den Lebensgeschichten dieser Generationen. Sie nennt das Buch Stille Post - so heißt das Kinderspiel, bei dem eine Botschaft von Ohr zu Ohr geflüstert wird: jeder versteht das Gesagte ein bisschen anders, und schließlich, am Ende der Kette, ist die Nachricht nicht mehr die, die sie am Anfang war. Mit dieser Metapher wird auf eine subtile Weise darauf hingewiesen, dass es eine offizielle Geschichte gibt, die meist von Männern gemacht und geschrieben wird. Und es gibt, zumal in Familien und unter Frauen, so schreibt Alex Rühle in der Süddeutschen Zeitung, das Nichtgesagte, aktiv Vergessene, Ausgeblendete, das sich viel wirkmächtiger in den Familienmitgliedern einnistet als alles Gesagte. ${ }^{4}$ Die Autorin beginnt ihr Buch mit einem Brief an ihre verstorbene Großmutter und versucht dadurch eine Form für diese Familiengeschichtsschreibung zu gewinnen, indem sie eigene Erinnerungen, spärliche Dokumente wie Briefe und Tagebücher und Erinnerungen mancher Familienmitglieder ineinander verwoben darstellt und versucht, eine andere Familiengeschichte, wie sie das Buch im Untertitel nennt, zu rekonstruieren. Das Buch ist im Frühjahr 2007 erschienen und erzählt uns die Geschichte der Frauen einer Familie in Deutschland zwischen Kaiserreich, Weimarer Republik, NS-Diktatur und Nachkrieg und verknüpft sie mit dem Gesamtbild der deutschen Geschichte.

Von Braun stellt die Lebensgeschichte ihrer Großmutter mütterlicherseits in den Mittelpunkt und erzählt auch die Geschichte ihrer Mutter und der Großeltern väterlicherseits. Die Großmutter heißt Hildegard von Margis, die 1944 im Polizeigefängnis an Herzinfarkt stirbt. Sie kommt ins Gefängnis aufgrund ihrer Mitgliedschaft im kommunistischen Widerstand. Über sie wird mit Stolz berichtet, dass sie innerhalb kurzer Zeit ein erfolgreiches Unternehmen aufbaut und zu den bestverdienenden und bekanntesten Frauen Berlins aufsteigt. Dabei ist Hildegard Margis am Ende des 1. Weltkriegs verwitwet und muss mit zwei kleinen Kindern zunächst schwere Lebensbedingungen bewältigen. Doch dann gründet sie eine Zeitschrift für Verbraucherinformationen und wenig später den „Hauswirtschaftlichen Einkaufs-, Beratungs- und Auskunftsdienst"“ (Heibaudi), ein Vorläufer der heutigen

\footnotetext{
${ }^{3}$ Braun (2007), S.10

${ }^{4}$ Rühle, Alex: Verdrängung ist die sicherste Form der Erinnerung, -in: Süddeutsche Zeitung, 21.03.2007
} 
Verbraucherzentralen. Schon zeitig wird sich diese Halbjüdin der Gefahr des NaziRegimes bewusst und schickt unter schwierigen Bedingungen ihren Sohn nach England. Ihrer Tochter will sie durch Heirat ein gesichertes Leben verschaffen, so wird sie verheiratet in die Familie von Braun, eine der bekanntesten Familien des damaligen Deutschlands. Sigismund von Braun ist Diplomat und sein Bruder Wernher von Braun baut Rakete für die deutsche Wehrmacht. Christina von Braun erzählt aber nicht die Geschichte dieser Männer sondern die ihrer Mutter und ihrer beiden Großmütter, Hildegard Margis und Emmy von Braun. Alle drei Frauen leben in unterschiedlichen Lebensbedingungen und ihre Schicksale unterscheiden sich auch sehr: Hildegard Margis, eine erfolgreiche Frau mit eigenständigem Charakter; Mutter der Autorin, eine unzufriedene Frau, die mit ihren Leidenschaften ständig auf Suche nach wahrer Liebe ist und vergleichsweise in einer gesicherten Umgebung lebt; und Emmy, die andere Großmutter, am Anfang Mitglied einer wohlhabenden Familie, erlebt aber in der Nachkriegszeit Vertreibung aus dem schlesischen Polen und muss das Hab und Gut dort verlassen und mit Schwierigkeiten nach Deutschland fliehen. Das Buch erzählt weiter, wie die verschiedenen Familienmitglieder sich nach dem Krieg allmählich sich in Deutschland, den USA bzw. in Australien etablieren.

Ich habe das Buch sehr interessant gefunden, nicht nur weil ich mich dadurch in die deutsche Geschichte anhand der erzählten Familie vertiefen konnte und so neuere landeskundliche Erkenntnisse gewinnen konnte, und nicht nur weil die Geschichte in einer spannenden künstlerischen Form angeboten wurde, sondern weil ich darin den Umgang einer deutschen Autorin mit der Geschichte nachvollziehen konnte. Ich konnte die Notwendigkeit einer deutschen Autorin in diesem Buch erkennen, die ihren eigenen Charakter durch das Erzählen ihrer Familiengeschichte zu ergründen versucht. Christina von Braun stammt aus einer bekannten Familie, deren Männer im Dienste des nationalsozialistischen Staates standen, ihre Geschichte erzählt sie aber nicht.

Sie versucht zu der Großmutter Hildegard von Margis, die sie nicht gekannt hat, ein neues Verhältnis aufzubauen. Die Autorin ist mit Recht stolz auf die Leistungen und Tapferkeit ihrer Großmutter. Die Großmutter hat eine für eine Frau außergewöhnliche Laufbahn. Als Frau ein vorbildliches und tapferes Leben in schwierigen Zeiten zu führen, ist etwas, mit dem sich die Autorin identifizieren will. Zum einen ist sie das Musterbild einer emanzipierten Frau, zum anderen beeindruckt sie die Teilnahme der Großmutter am kommunistischen Widerstand gegen Hitler. Sie ist die Tochter einer jüdischen Mutter, also eine Halbjüdin, hat außerdem jüdischen Freunden und anderen Gegnern des Nazi-Regimes heimlich geholfen. Des Weiteren hat sie für ihren Sohn die Flucht nach England rechtzeitig organisiert. Ziemlich viele Gründe für die Autorin, zu sagen: ja, hier liegen meine Wurzeln, ich bin das Enkelkind solcher Großmutter! Nicht das Leben ihrer eigenen Mutter, die ein Gegenbild zu deren emanzipierten Mutter darstellt, oder das Leben der anderen Großmutter scheinen der Autorin wert zu sein, sich mit ihnen zu identifizieren. 
Das zweite Buch, das ich anführen möchte, ist auch eine Familiengeschichte. Es ist das im Jahr 1999 erschienene Buch Monika Marons Pawels Briefe. ${ }^{5}$ Das ist die Geschichte ihres Großvaters, die sie rekonstruiert, und zugleich ist sie die Geschichte einer Tochter-Mutter-Beziehung, die wegen zwei unterschiedlicher politischer Standpunkte zu scheitern droht. Das Buch ist mehr als eine Familiengeschichte, es ist Erinnerungsarbeit, wie Maron es versteht.

„Erinnerungen haben ihre Zeit. Es gibt Ereignisse, von denen wir nur ungenau erfahren und von denen wir wissen, dass wir eines Tages ihrer in Ruhe gedenken und sie genauer gedenken wollen... So, glaube ich, ist es mir mit der Geschichte meiner Großeltern ergangen“" ${ }^{6}$

So schreibt Monika Maron am Anfang ihrer Erinnerungsarbeit, in der sie die Briefe ihres Großvaters zum Anlass der Arbeit macht. Sie schreibt nicht nur über ihre Großeltern und über ihre Mutter, sondern auch gleichzeitig über den Weg, den diese beiden Generationen gegangen sind, anschließend schreibt sie auch über ihre eigene Vergangenheit in der DDR. Bei der Lektüre dieses Teils stellen sich für mich als ausländische Leserin einige Fragen. Es scheint, dass hier Maron hat entscheiden müssen zwischen Schreiben und Schweigen; manche Stellen hinterlassen den Eindruck, man hätte hier noch mehr erzählen können bzw. sollen. Mit einer Mischung von Rückblenden und Momentaufnahmen in der Gegenwart schafft Maron einen persönlichen Überblick über die Sozialgeschichte ihrer Zeit.

Monika Maron lässt mit Hilfe eines Kartons, in dem Pawels Briefe enthalten sind, ein Familienporträt über drei Generationen entstehen. Pawel Iglarz ist der Großvater Monika Marons und hat an seine Frau und Kinder aus dem Ghetto Belchatow Briefe geschrieben. Er ist jüdischer Abstammung, hat mit seiner katholischen Frau seine polnische Heimat verlassen, um nach Berlin zu übersiedeln. Als Schneider verdient er seinen Lebensunterhalt, er hat vier Kinder. Pawel, der konvertiert ist, wird dennoch 1942 als Jude ins polnische Ghetto deportiert und später vermutlich entweder in den Wäldern erschossen oder in einem Vernichtungslager ermordet. Die Briefe an seine Frau und nach ihrem Tod an seine Kinder erzählen von seiner Zeit im Ghetto. Anhand dieser Briefe und einiger Fotos von Pawel und seiner Familie versucht die Autorin, die damit verbundene Vergangenheit ihrer Familie zu rekonstruieren. In dieser Geschichte kommen außer Pawel verschiedene Personen vor, vor allem Josepha, die Großmutter, Hella die Mutter und die Autorin selbst mit ihrer Familienvergangenheit und -gegenwart.

Monika Maron stellt ihrer Mutter Fragen nach ihrer Kindheit. Inzwischen hat die Mutter durch Vergessen Momente ihres Lebens verloren, die die letzten Tage der Eltern in dem polnischen Dorf, wohin sie aus Berlin ausgewiesen werden, betreffen. Die Kinder können den Vater nicht mehr sehen und auch nicht die Mutter, dann stirbt die kranke Mutter in Polen allein. Die Mutter Hella erinnert sich

\footnotetext{
${ }^{5}$ Maron, Monika: Pawels Briefe, Frankfurt/M. 1999

${ }^{6}$ ebd., S.7-8ff.
} 
nicht an die Briefe des Vaters, die er aus dem Ghetto geschrieben hat und die sie beantwortet hat.

„Ihre [Hellas] Geschwister Marta und Paul sind tot. Es ist niemand mehr da, der ihr durch die eigenen Geschichten oder auch nur durch die eigene Existenz helfen könnte, den Weg des Vergessens zurückzugehen. Wir können uns erklären, warum wir uns an etwas erinnern, aber nicht, warum wir vergessen, weil wir nicht wissen können, was wir vergessen haben, was uns zugestoßen ist". 7

So sammelt und rekonstruiert die Erzählerin die Geschichte Pawels. Die Geschichte erscheint nicht linear, sondern wird von Blicken in die Gegenwart, durch die gegenwärtigen Gespräche, ihre eigenen Reaktionen über das Vergangene unterbrochen. In dem zweiten Teil des Buches wird die Geschichte ihrer Mutter und somit die Geschichte der ersten Generation der DDR, die ihr Land und die Partei neu aufgebaut hat, erzählt. Maron schreibt in einem assoziativen Erzählstil, der Text stellt kleinere Puzzelstücke einer Zeitperiode dar, die miteinander verknüpft sind, aber in der Erinnerung der Erzählerin als Bruchstücke vorkommen.

Gegen Ende dieser Familiengeschichte kommt eine Stelle, in der die Unterschiede in den drei Generationen hinsichtlich Glaube und Ideologie unterstrichen werden:

„meine Großeltern haben ertragen müssen, dass keines ihrer Kinder sich taufen ließ; Hella hat gelernt zu ertragen, dass ich Antikommunistin wurde; und ich muss ertragen, dass Hella Kommunistin bleibt". 8

Der letzte Absatz des Buches bezieht sich nochmals auf Glaube und Ideologie: „In unserer Familie ist niemand dem Glauben treu geblieben, in dem er erzogen wurde. Pawel ist nicht Jude geblieben, Josepha nicht Katholikin, Hella, Marta und Paul haben sich nicht von den Baptisten taufen lassen, und ich habe mit der Zeit aufgehört, an den Kommunismus zu glauben“.?

Die Erinnerungsarbeit Marons erzählt uns, wie jeder in seinem Leben immer andere Sehnsüchte und Wünsche hatte. Dadurch kommt auch eine gespannte Beziehung zwischen Eltern und Kindern zur Sprache. Das Leben Pawels und Josephas und ihre Einsichten sind von vorkriegszeitlichen Werten geprägt. Gegen den Willen seiner Eltern hat Pawel seine jüdische Abstammung abgelehnt und sich konvertieren lassen, heiratet eine Katholikin und übersiedelt in die Großstadt Berlin. Das Leben der jungen Hella, die in dem Elternhaus eine glückliche Kindheit verbracht hat, wird von dem sozialistischen, kommunistischen Land geprägt, frei von jedweder Religion, dem Land und der Partei treu. Sie ist daher später nicht in der Lage, die Position ihrer Tochter zu verstehen, die ihr Buch in einem westdeutschen Verlag zur Veröffentlichung gibt und öfter das West-Deutschland besucht. Die Beziehung zwischen Hella und Monika Maron ist gespannt und verspitzt, bis die

\footnotetext{
7 ebd., S.18

8 ebd., S.205

${ }^{9}$ ebd., S.192
} 
Mutter entscheidet, die Beziehung zur Tochter frei von ideologischen Belangen zu halten und sich mit ihr zu versöhnen.

Interessant ist auch die Lebensgeschichte von Monika Maron in der DDR, die früher Iglarz hieß - wie Pawel und Josepha und so auch Hella, aber nach deren Heirat mit Karl Maron übernimmt sie den Namen des Stiefvaters. Karl Maron arbeitet als Chef der Deutschen Volkspolizei und 1955 wird er zum Innenminister der DDR. Über die Jahre, die sie als Stieftochter von Karl lebt, schreibt sie sehr wenig, erwähnt nur, dass sie 12 Jahre Mitglied der SED gewesen ist und dann aus der Partei freiwillig austritt. Sie schreibt über das Schweigen ihrer Mutter über einige politische Ereignisse, welche sie, Hella, als treues Parteimitglied nie in ihre Tagebuchaufzeichnungen eintragen will. Maron schreibt, dass sie sich nach dem Tod Karls frei fühlt, und dass sie nach dem psychischen und physischen Zusammenbruch zu schreiben anfängt. Sie schreibt:

„Ich weiß bis heute nicht genau, warum mir, solange Hellas Mann lebte, alles unmöglich erschien, was ich, als er gestorben war, nach und nach einfach tat, wie ein umgeleiteter Fluss, der sein natürliches Bett wieder findet, nachdem das künstliche Hindernis aus dem Weg geräumt wurde. Ich schrieb, ich trat aus der SED aus und veröffentlichte mein erstes Buch, nachdem man es in der DDR nicht drucken wollte, entgegen allen früheren Beteuerungen doch im Westen". 10

Maron schreibt, wie sie die Ausreiseerlaubnis von der DDR-Behörde bekommt, um in den Westen zu fahren, wie sie ihre „mangelnde Eignung für eine Agentenkarriere eingestand", für die Staatssicherheit zu arbeiten einwilligt und wie sie dafür 1995 in der Öffentlichkeit heftig kritisiert und als Denunziantin bezeichnet wird. Über diese Episoden wird nur kurz geschrieben, und es erscheint wie eine Rechtfertigung. Maron ist in diesem zweiten Teil ihres autobiographischen Buches sehr selektiv und schreibt nicht ausführlich über ihr Leben in der DDR.

Beachtenswert ist hier der Umgang Marons mit der eigenen DDR-Geschichte. Maron gehört, wie in diesem Buch zu lesen ist, zu den privilegierten Menschen in der DDR. Ihr Stiefvater ist Innenminister der DDR. Sie darf ihre Manuskripte an einen Westverlag schicken, sie bekommt Ausreiseerlaubnis für Westberlin und darf mit Westdeutschen frei umgehen. Kurz und meist halb verschwiegen schreibt sie hier über diese Zeit. Warum spürte sie das Bedürfnis, die Geschichte ihres Großvaters ausfindig zu machen, die sie nur mit spärlichen Dokumenten und mit viel Mühe rekonstruieren musste? Warum aber schreibt sie dann nicht in Einzelheiten über die Zeit, die sie selber in der DDR lebte?

Beide Familiengeschichten Stille Post von Christina von Braun und Pawels Briefe von Monika Maron erzählen Familiengeschichten der drei Generationen. Zugleich zeigen sie einen Längsschnitt durch die deutsche Geschichte des 20. Jahrhunderts. Beide Autorinnen versuchen, unterschiedliche, sogar gegensätzliche Lebenswelten aufzuzeichnen und sie miteinander in Beziehung zu setzen. Christina von Braun

10 ebd., S.194-195ff. 
steht deutlich an der Seite ihrer Großmutter Margis und macht dadurch ihren politisch ideologischen Standpunkt erkennbar. Maron steht auf Distanz zur Geschichte ihres Großvaters, pendelt sich zwischen Schweigen und Schreiben, wenn sie sich mit ihrer DDR-Zeit befasst.

Beide Bücher sind lesenswert auch im Hinblick auf weitere literarische und genrespezifische Merkmale, worauf ich hier nicht eingehen will. Mir geht es darum aufzuzeigen, wie anhand von Familiengeschichten und Autobiographien von Frauen sowohl über die Sozialgeschichte bzw. Zeitgeschichte als auch über das persönliche Verhalten in einem bestimmten sozial-politischen und kulturellen Rahmen zu erschließen sind. Interessant sind diese beiden Ebenen, nämlich das Kollektive und das Private bzw. das Persönliche, die durch solche Selbstgeschichten erkennbar werden. Für einen Ausländer ist es spannend zu beobachten, wo die Grenze zwischen dem realen Geschehen und der selektiven Rekonstruktion der Realität aus einer persönlichen Perspektive liegt. Solche Familien- bzw. Selbstgeschichten bieten dem ausländischen Leser einen perspektivischen, einen anderen Zugang zur fremden Kultur. Autobiographien und Familiengeschichten als ein Genre zwischen Fiktion und Realität weisen auf weitere Möglichkeiten des Verständnisses historischer Geschehnisse und erweitern so Horizonte des kulturellen Verständnisses.

\section{Literatur}

Braun, Christina von: Stille Post. Eine andere Familiengeschichte, Berlin 2007

Gilson, Elke (Hrsg.): „Doch das paradies ist verriegelt... “ Zum Werk von Monika Maron, Frankfurt/M 2006

Gilson, Elke (Hrsg.): German Monitor. Monika Maron in Perspektive. Dialogische Einblicke in zeitgeschichtliche, interkulturelle und rezeptionsbezogene Aspekte ibres Werkes, Amsterdam-New York 2002

Holdenried, Michaela: Autobiographie, Stuttgart 2000

Holdenried, Michaela (Hrsg.): Geschriebenes Leben. Autobiographik von Frauen, Berlin 1995

Lejeune, Phillipe: Der autobiographische Pakt, Frankfurt/M 1994

Lezzi, Eva: Zerstörte Kindheit, Köln-Weimar-Wien 2001

Maron, Monika: Pawels Briefe, Frankfurt/M. 1999

Sloterdijk, Peter: Literatur und Organisation von Lebenserfahrung. Autobiographien zwanziger Jahre, München 1978

Vogt, Marianne: Autobiographik bürgerlicher Frauen. Zur Geschichte weiblicher Selbstbewußtmachung, Würzburg 1982 
Wimmer, Andreas/Glick Schiller, Nina: Methodological nationalism and the study of migration: Beyond nation-state building, -in: International Migration Review, 37 , 3, 2002, S.576-610 http://edoc.mpg.de/28957 



\title{
Experiences in Intercultural Training in Germany and India. A Comparison of the German and Indian Mind-set at the Workplace
}

\author{
Intercultural Communication \& Competence - \\ in Practice I
}

Janaki Narkar-Wallraff

Why Intercultural Competency?

Intercultural competence in today's globalised world is a Must, as has been established in many ways by many experts in the field. Cultural diversity is a given and its progressive flattening by increased trade between nations has been perceived to be undesirable by some, and a call for adaptation to the inevitable has been heard. The paradigm shift in today's corporate world from emphasis on economic prosperity and performance to interpersonal relationships and social growth in a global world has made trainings in intercultural skills imperative. 
My purpose today is to present actual experiences and narrate my observations while sensitising ${ }^{1}$ managers, engineers, IT professionals of both German and Indian nationalities to this highly important and often sensitive topic. There is no value judgement or praise for national characteristics. This is a statement of observations and management study, while working as a corporate trainer. It is not to be forgotten that each and every training session is a learning experience - not only for the participants, but also for the trainer.

\section{The Process of Training}

As we all know, it is important to have information about the target group that one aims to sensitise. Normally, training sessions last for 1 to 2 days. Prior information is collected with a short questionnaire, which requires the participants to state their travels, educational level, actual work and position in the organization and which topics they would like to see dealt with during the seminar. Based on the requests and answers obtained, the programme is custom designed to satisfy these specific needs.

These demands and requests are important as they facilitate the focusing on and highlighting certain important contents of the seminar. All sessions are highly interactive, with role playing, quizzes, analysis of case studies, group work, PPTs etc. The length of such sessions depends entirely on the reception of information provided, as a major part of its content is closely linked to the psychology of the human being and to different mind-sets.

Given the time constrains; in general, the progress of the seminar develops from the abstract to the specific contrast of pragmatics. An abstract start would be to ask the participants about their understanding of the definition of culture e.g. what is culture? It is amazing to hear the various definitions.

After a short introduction to the geographical and historical dimensions of the other country, climatic conditions, various languages, ethnic groups and religions, one progresses to the actual handling and dealing with people of the other culture in the business environment. Understanding cultural diversity, both mentally and emotionally, are important to intercultural communication. Identifying the different factors that influence and determine it, makes for easy and rapid comprehension.

\section{Differences and Similarities}

National characteristics, appearance and reality, stereotypes and preconceived notions about a certain group of people, behaviour patterns and reactions are part of this analysis.

\footnotetext{
${ }^{1}$ I use here the word "sensitise", as most of these professionals do not have the time for extended study of the other culture.
} 
To elaborate on this thought of cultural diversity, it is interesting to have a short look at the different types of cultures as studied by sociologists and linguists like Richard D. Lewis (linear - active-data oriented, multi - active-dialogue oriented, reactive - listeners). The seminar participants immediately choose their cultural conditioning, deny most others and get defensive. The mention of different cultures serves to emphasize the fact that there are differences and similarities between cultures. To make business effective, it would therefore be advisable to underline the similarities and work towards the understanding of the differences, whereby one encourages the simultaneous development of strategies and coping mechanisms.

The image of a certain group of people (in this case the Germans and the Indians) often leads to defensive reactions. E.g. the Germans are known to stand for law and order. The Indians in comparison are rather flexible in their understanding of the same. Germans tend to be precise and exact in their description of requirements. They often see a "problem" in a given situation. Indians are used to changes in circumstances (political, social etc.) and are highly adaptive. They therefore approach a situation with solutions. Precise planning of every stage of a process is one of the strong points of the German business mind-set. The Indian mindset, in contrast, is programmed to finish a task, using spontaneity and intuition, adapting to the changes in circumstances. Bargaining and negotiating in retail businesses was legally forbidden in Germany till 2002. However, negotiating in India has evolved over the centuries to a high art form and is considered an integral part of doing good business. Germans are known to be the "Do-it-yourself" type, however, Indians, embedded in their hierarchical structure, require assistance from several sources (office boys, assistants, chauffeurs, household maids etc.) - just to mention a few examples.

\section{Communication across Cultures}

One works ideally with generalizations to provoke reactions, but one needs to continuously emphasize the fact that in business, one is dealing with people and not machines. One cannot therefore deny the importance of effective communication. Another fact that is continually mentioned is that cultures are not static. There is constant evolution in the many spheres that encompass and define a culture; e.g. the Indian or German business culture of the $70 \mathrm{~s}$ or $80 \mathrm{~s}$ as compared to the business culture of today.

The importance of societal training in leadership styles as displayed in organizations cannot be denied. Awareness of the source of this type of behaviour often alters reactions and facilitates better intercultural communication. Decision making processes (individual or collective, hierarchical or consensus), linguistic arrogance, dollar status, perception of organizational procedure etc. are some of the many topics that cover this area of communication. 


\section{Negotiation Styles and Communication}

Negotiation and communication styles of different cultures occupy a major part of the discussions as the participants hope for concrete answers to some of the communication problems that they encounter at their workplace.

To give a certain example: The value of a "Yes" in the German sense is binding. It implies a commitment to the business at hand. A "Yes" in the Indian context can imply several of the following: Yes, I am listening to you; yes, I understand what you are saying; yes, please continue; yes, I agree and believe your point of view - however, it does not imply a commitment to the business at hand. Similarly, the value of a "No" in the German context is definite. It often does not leave any room for further discussion. Whereas, in the case of the Indian business mind-set, it is considered to be a momentary set-back in negotiations and is not to be taken as a definite. There is still room for discussion and negotiation after a certain period of silence and reflection. Germans tend to take the "entweder - oder" (either - or) stand, whereas Indians tend towards the "sowohl - als auch" (as well as) approach to business, which is appropriate to the national business conditions.

Germans are short, direct, to the point and precise in their verbal communication. This tendency is often perceived by Indians as being abrupt, cold and impolite. Indians are known to be talkative, indirect, insinuating, reading between the lines and often ambiguous in their verbal communication of content, which in turn is interpreted negatively by the other culture (Germans).

Add to this the often expressive body language of the average Indian or the relative lack of body and facial movement of the typical German - and it makes for total disorientation or ambiguity and can lead to gross misunderstanding in business dealings.

\section{Empathising with the "Other" Culture}

Knowledge of, and training in these different forms of communication is essential for effective and productive functioning in the corporate world.

There is much doubt and apprehension about the image that is projected to the other culture in business. Self-doubt is healthy, because it augments the willingness to learn, to ask for help and build a receptive and open mind. Some of the frequently asked questions are: What do the Germans/Indians think of us? What is the image that our work ethic projects? What do they think of us when we behave the way we do?

Giving a definite answer to these kinds of queries would be foolish, as I already said: business means dealing with people and not with machines. Each individual brings with him (or her) a predetermined set of values and behaviour patterns. Generalising can be useful in the beginning as a frame of reference, but one has to learn to differentiate and develop coping mechanism. 


\section{Problems and Barriers to Intercultural Training}

In this vein I would now like to come to some of the problems and barriers that are encountered during training.

Any kind of change in the perception of an established notion or concept involves an internal change in the individual personality and a certain amount of selfreflection. The process of denial, defence, minimization and acceptance are actively utilized. The last two stages of adapting and integration are approached with great caution. In fact, integration is seldom achieved. Factors that hamper this process are stereotyping, perception of the other, an innate stubbornness and resistance to change, an arrogance born of financial benefits (economic colonisation) and lastly identity crisis - not to forget language problems!

Intercultural training often touches on personal characteristics and highlights the fact that most people refuse to leave their comfort zone, but expect members of the "other" culture to adapt, learn and adjust to their cultural patterns. Identity crisis is defined in the following accusatory manner: "You say that if I have to do business effectively with the Germans or Indians, I have to be like them. But I don't want to be like them. I have my own identity and in fact, I am proud of what I am - of being a German or an Indian. So don't tell me to change! - It is they, who have to change!"

The issue is not to change one's personality or loose one's identity, but to enrich it by being aware of the differences in culture, in communication styles, in behaviour patterns and reaction modes. The issue is to emphasize the similarities and to develop empathy and effective strategies/tactics/coping mechanisms for dealing with these differences so that productive work and communication are not negatively affected.

\section{Language}

The power of language is immense. A clumsily formulated sentence could lead to extreme negative reactions. Language in management and business can be an effective and important tool to success and it is often noticed that much emphasis is placed on the acquisition of technical knowledge in both countries and little on language and social skills. One therefore finds extremely intelligent, innovative and competent professionals who are, however, incapable of transmitting their thoughts and emotions due to lack of language skills.

\section{Concluding Remarks}

Intercultural training programmes are valuable tools to better understanding, enhancing performance and effective functioning in mixed culture teams. Management studies have repeatedly shown the success and importance of prior training. 
Such training programmes are proving to be the benchmark for interpersonal relationship and successful business practices.

In conclusion, I would like to mention that in spite of all problems and barriers in intercultural communication in business, my observation has been that money talks and that business is business. Whether it makes for good business practice, good listening skills, personal and job satisfaction, growth and long term business deals, is yet to be seen. 


\title{
Translation as a Tool of Negotiation
}

\author{
Intercultural Communication \& Competence - \\ in Practice II
}

Anagha Bhat

I

On $9^{\text {th }}, 1^{\text {th }}$ and $11^{\text {th }}$ February 2006 an International Symposium on grape growing was held in Baramati, Maharashtra/India. 1100 agriculturists from all over India participated in it. 44 agricultural scientists and experts from 20 countries were going to present papers at the symposium. The working language of the symposium was English. But the participants, a majority of whom were coming from rural Maharashtra, asked for a simultaneous interpretation of the papers in Marathi, a simultaneous interpretation from English into Marathi: an example of the globalto-local communication. I was invited as the interpreter. The content of the communication was purely technical.

In order to reach such a large audience, the organizers of the symposium came up with an innovative idea. The interpretation was to be broadcasted on a local FM radio station. I was going to sit in a radio station belonging to an educational institute, Vidya Vahini, and was given an audio and visual input from the auditorium 
Anagha Bhat

where the symposium was to take place. It was located at a distance of about 100150 metres from the FM studio and the simultaneous interpretation was broadcasted live on the FM channel. The participants of the symposium were provided with a small FM radio and headphones. While attending the symposium, they could tune in the radio and listen to the simultaneous interpretation of the papers being presented. People in Baramati and surrounding area falling in the FM range could also tune in their radio sets and listen to the live broadcast.

While interpreting I had to keep in mind a few things like the nature of the communication process and the role of technology in facilitating the communication. There was going to be no actual contact between the first communicator that is the paper reader, the interpreter that is me and the recipient of the communication, the audience. I was completely dependent on the technological support for the inputs. Since I was physically removed from the paper reader, there was no possibility I could ask them to repeat something or ask for a clarification and since my interpretation was going to be broadcasted over FM radio, it had to be like a running commentary.

The major problem involved in this type of interpretation was the varying syntactic behaviour of English and Marathi languages. In Marathi we usually come across a construction where the subordinate clauses precede the major clause. English on the other hand favours a construction with the major clause coming first followed by the subordinate clauses. So a sentence in Marathi could be started only after having heard completely the sentence in English. Hence there was a difference in the tempo of the speech, an essential time gap in the original message and its translation in Marathi. But the effort was successful and was fully appreciated by the participants.

\section{II}

The entire process raised some questions about the role of a language in the process of acquisition of knowledge, medium of instruction and linguistic abilities, globalization and people's participation in it. The participants who availed of the facility of simultaneous interpretation came from various social strata of the society. There were some with university degrees, some undergraduates, some just about literate. Also those participants who had a considerable exposure to English were more comfortable with the Marathi translation. Even those conversant with English could not use the linguistic ability of listening, i.e. taking in the linguistic message and decoding it.

In the last few decades English has come to play a very dominating role in the Indian education scenario. In most of the universities in India the medium of instruction at the graduate and postgraduate level is English. An attempt was made to provide graduate and undergraduate level training in the universities in native languages. It met with a spectacular failure for various reasons. Soon after Independence English became the new 'Devavani' (the language of gods). Just as in the 
case of Sanskrit in the earlier times, English became a prerogative of the elite. As a consequence, more and more people wanted their children to be educated in English medium schools. Knowledge of English became a kind of a passport to enter the elite club. The politicians started making populist slogans like making English compulsory from the first standard. Around this time the opening of the Indian economy took place. Now with the multinationals and the BPOs knowing English came to be viewed as the most essential skill for upward mobility. Both these trends, the elitist view jealously guarding English and the populist view making English compulsory from the primary school level are quite dangerous. There is no denying that English is a very important tool of communication in the era of globalization. But one must also keep in mind that English is a language mediator and cannot replace the mother tongue. This kind of self contradictory and confusing policy on English has raised a generation that can have a "Radio Mirchi" type of communication, consisting of a hotch-potch of two or more languages, but which is unable to understand fully a message of highly technical nature and express something meaningful, something that goes beyond phatic level communication.

Ideally, all those who have studied English should be able to speak, read, write and understand oral messages in English. But at least as of today this goal seems to be distant. Fulfilling this goal would mean overall review of teaching of English in schools and introduction of corrective measures in the teaching methods and curricula. This is essentially a long-term project. Till this objective is realized the communication will essentially be through translation. Secondly, though English has gained currency as a language mediator, today in the era of globalization people speaking various languages are constantly being thrown into contact with each other. Under such circumstances English no doubt helps to bring about communication but it's time to look beyond English if any "real" communication is to take place.

\section{III}

Language gives you a perspective to look at your surroundings. Your surroundings in turn shape the language you speak. As the surroundings become more and more complex, the language has to keep pace. Any language keeps doing that. It borrows words from other languages, some times it borrows phrases and some times it just gives new twists to the old elements. In spite of these changes and modifications it remains "your" language, "your" tool, "your" perspective. There are others who speak "their" language, express "their" perspective. How do you understand "their" perspective then? The closest that you can go to their perspective is through translation. Translation tells you in "your" language how the view from "their" language perspective is. So your understanding about your surroundings and your language deepens.

They say that translation is an act of violence. Yes, it is an act of violence, but not an act of vandalism. It violates the norms of "your" language, only to set up 
new norms; only to accommodate "their" perspective. In this sense it is a process of compromise and communication. It helps people understand each other better.

To understand people has become an imperative in the era of globalization. The market aims at understanding people as customers, clients, consumers and facilitators. It also throws people of divergent ethnicities, languages and viewpoints together. At the same time it flattens out dissimilarities between people, turning them into humanoids that wear similar clothes, view similar films, eat similar food and enjoy similar music. Essential fall out of this process is resentment against "others".

Translation, especially that of literature, helps you understand people as human beings. It helps you understand the "other" without asking you to jettison your identity. It also helps you understand your own self, better. You can appreciate the similarities you share with others and you can understand dissimilarities among people. It is only through translations that you can understand various ideological constructs. Only when you understand them, you can have the ability to withstand them or propose alternatives. Our future depends upon how we accommodate the perspective of others, how we modify old ideas and how we come up with new ideas. Translation will help us preserve ourselves without viewing others as threat. It will also provide opportunities to have successful communication and to reduce strife. 


\title{
Transkulturelle ${ }^{1}$ Psychiatrie. Ein Beitrag zur interkulturellen Verständigung
}

\author{
Elisabeth Reif
}

Psychiatrie beschäftigt sich mit der Ätiologie, der Häufigkeit und den Arten geistiger Erkrankungen sowie deren Behandlung. „Transkulturelle Psychiatrie“ bedeutet, dass „der wissenschaftliche Beobachter über den Bereich einer kulturellen Einheit hinausblickend andere Kulturbereiche miteinbezieht" ${ }^{2}$ Dieser Blick über den eigenen „kulturellen Tellerrand“ und zurück verändert auch die Sichtweise auf die eigene(n) Kultur(en). In diesem Artikel möchte ich eine spezielle Richtung der Transkulturellen Psychiatrie vorstellen, die sich aus der Ethnopsychoanalyse und Ethnopsychiatrie heraus entwickelt hat und mit einer speziellen Theoriebildung und einem therapeutischen Ansatz verbunden ist. Zusammen mit Beiträgen indigener Psychologien hinterfragt diese Richtung im Westen übliche psychiatrische Diagnoseschemata und das Postulat einer universell gültigen (westlichen) Psycho-

\footnotetext{
${ }^{1}$ Der Begriff „Transkulturalität“ wurde von Welsch geprägt (Welsch, W.: Transkulturalität. Lebensformen nach der Auflösung von Kulturen, -in: Luger, K./Renger, R. (Hrsg.): Dialoge der Kulturen, Wien-St. Johann in Pongau 1994) und bezeichnet vielschichtige, dynamische Gebilde, die der Vorstellung von ,abgegrenzten, stabilen Kulturen” entgegenstehen. In diesem Sinne verwende ich auch die Begriffe „Interkulturalität" und „Kultur" im Allgemeinen, obwohl diese von Welsch als ungeeignet betrachtet werden. Meines Erachtens können aber auch diese Begriffe in einem kritischen Sinne angewandt werden, d.h.: Kulturen sind nicht homogen, überschneiden sich mit anderen, werden erlernt und verändern sich. Individuen haben meist an mehreren Kulturen Anteil und Kultur ist nur eines von vielen anderen Kriterien, wie soziale Schicht, Gender, Hautfarbe, Alter, sexuelle Orientierung etc., die allesamt spezifische Erfahrungen mit sich bringen und unsere Wahrnehmung, unser Denken und Handeln beeinflussen.

2 Wittkower, E. D.: Probleme, Aufgaben und Ergebnisse der Transkulturellen Psychiatrie, -in: Ehrhardt, H. E. (Hrsg.): Perspektiven der heutigen Psycbiatrie, Frankfurt/M 1972, S.305-312
} 
logie. Der kulturrelativistische Blickwinkel erleichtert die interkulturelle Verständigung - nicht nur im psychiatrischen Bereich.

Die Geschichte der Transkulturellen Psychiatrie ist zunächst einmal mit dem Namen Emil Kraepelin (1856-1922) verbunden. Er gilt als Begründer der klinischen Psychiatrie. Von ihm stammt das für die westliche Psychiatrie wichtige Konzept der „Dementia praecox“ - die später von Eugen Bleuler als „Schizophrenie“ bezeichnet wurde. Kraepelin gilt auch als Begründer des psychiatrischen Klassifikationssystems, insbesondere durch seine Aufteilung der Psychosen in Dementia Praecox und „Manisch-depressives Irresein“. Sein Klassifikationssystem war es schließlich auch, das sein Interesse für fremde Kulturen weckte, denn er wollte den Beweis erbringen, dass seine Klassifikation universell gültig sei. Also machte er sich 1904 gemeinsam mit seinem Bruder auf die Reise nach Java - damals „Niederländisch-Indien“. Die Holländer hatten dort psychiatrische Anstalten unter holländischer Leitung errichtet. Kraepelin hatte die Möglichkeit, hundert einheimische PatientInnen zu untersuchen. Wenig überraschend - fand er sein Diagnosesystem bestätigt. Bei den einheimischen PatientInnen aus Java diagnostizierte er zu 70\% Dementia praecox. Fälle von „Amok“ reihte er unter die Kategorie „Epilepsie“ ein. Insgesamt schrieb Kraepelin den „Wilden“ von Java eine niedrige geistige Entwicklung und ein weniger reiches Seelenleben zu. Daher seien auch die Wahnsysteme der Patienten, denen er „Dementia praecox“ diagnostiziert hatte, weniger differenziert.

Kraepelin hatte also systematische psychiatrische Untersuchungen in fremden Kulturen gemacht - man kann ihn aber kaum als Begründer der Transkulturellen Psychiatrie bezeichnen. Er hatte den Anspruch, die universelle Gültigkeit seiner psychiatrischen Kategorien zu bestätigen. Die sich später aus der Ethnopsychoanalyse und -psychiatrie entwickelnde Transkulturelle Psychiatrie machte hingegen einen entgegengesetzten Schritt und führte wieder eine kulturrelativistische Sichtweise in die Psychiatrie ein. In der Entwicklung der Transkulturellen Psychiatrie spielte die Infragestellung der zentralen Position der Dementia praecox bzw. Schizophrenie und die Frage der Übertragbarkeit dieser psychiatrischen Kategorie auf andere Kulturen eine große Rolle. Wesentlichstes Kriterium im SchizophrenieKonzept ist die „Ich-Störung“, die sich als „Entgrenzung“ in Form von Gedankeneingebungen, Gedankenentzug und Gedankenausbreitung manifestiert. Kritiker dieser „universalen Schizophrenie-Kategorie“ führen dabei an, dass das Schizophrenie-Konzept nicht unabhängig von der Idealisierung einer bestimmten Ichstruktur im Westen gedacht werden kann. Nach Erich Wulff $(1978)^{3}$ setzt eine „Ich-störung“ ein abgegrenztes „Ich-bewusstsein“ voraus, daher sei auch die Schizophrenie häufiger in westlicheren, individualisierteren Gesellschaften zu finden. Wulff hatte von 1961 bis 1967 einen Lehrauftrag an der Medizinischen Fakultät Hue in Vietnam. Laut Wulff gibt es in Vietnam keine Schizophrenie, in Schwarzafrika und Indonesien sei sie selten. Die WHO führte von 1966-1974 eine Längs-

${ }^{3}$ Wulff, E.: Ethnopsychiatrie. Seelische Krankheit - ein Spiegel der Kultur? Wiesbaden 1978 
schnittstudie über den Krankheitsverlauf von als „schizophren“ diagnostizierten PatientInnen in einigen westlichen Industrieländern (z.B. USA, GB, Dänemark) und einigen „Entwicklungsländern“ (z.B. China, Nigeria, Indien) durch. ${ }^{4}$ Dabei zeigte sich, dass die Prognose für diagnostizierte schizophrene Erkrankungen in China, Nigeria und Indien wesentlich besser war, als für PatientInnen in den USA, GB und Dänemark. Für Indien ergab die WHO-Studie, dass sich 64\% der als schizophren diagnostizierten PatientInnen bereits zwei Jahre nach der Diagnose in einer Remission befanden und nur mehr 11\% als psychisch krank eingestuft wurden. ${ }^{5}$ Srinivasan und Tirupati zeigten in einer 2005 publizierten Studie ${ }^{6}$ über Schizophrenie und Berufsarbeit in Indien, dass 67\% ihrer als schizophren diagnostizierten PatientInnen berufstätig waren, die meisten von ihnen Vollzeit in „mainstream jobs“ mit kaum eingeschränktem Funktionsniveau. ${ }^{7}$

Zur westlichen Kategorie „Schizophrenie“ gehört also nicht nur die besagte Ich-Störung, sondern auch ein chronischer Verlauf mit einer schlechten Prognose - auch dieses Merkmal konnte keineswegs kulturübergreifend bestätigt werden.

Interessanterweise taucht die Diagnose „Schizophrenie“ z.B. in den USA und in Dänemark bei MigrantInnen häufiger auf als bei Einheimischen, was zu unterschiedlichen Theorien führte: a) Die erste Theorie besagt, dass tendenziell häufiger solche Menschen migrieren, die anfälliger für psychiatrische Erkrankungen sind. b) Die zweite Theorie besagt, dass Migration Stress erzeugt und häufig psychisch krank macht. ${ }^{8}$ Darüber hinaus wurde in Migrationsstudien herausgefunden, dass bestimmte ethnische Gruppen in manchen europäischen Ländern eine höhere Wahrscheinlichkeit haben, eine Schizophrenie-Diagnose zu bekommen, als andere: so z.B. afrikanisch-karibische MigrantInnen in England und anderen europäischen Ländern, marokkanische MigrantInnen und solche aus Surinam und den Niederländischen Antillen in den Niederlanden, ostafrikanische MigrantInnen in Schweden u.a. ${ }^{9}$ Dabei scheint sich eher die zweite genannte obige Theorie durchzusetzen: Migration erzeugt Stress und macht häufig psychisch krank. Ein Teil dieses Stresses und der höheren Wahrscheinlichkeit einer „Schizophrenie-Diagnose“ wurde auf den Grad der kulturellen Distanz von Herkunfts- und Einwanderungsland zurückgeführt - je größer der kulturelle Unterschied, desto höher auch die Anfälligkeit für eine Schizophrenie-Diagnose. ${ }^{10}$ George Devereux, der Begründer der Ethnopsychoanalyse und Ethnopsychiatrie, beschreibt Schizophrenie als „ethnische Psychose“, als Orientierungsstörung in westlichen komplexen Gesellschaften.

\footnotetext{
${ }^{4}$ WHO World Health Organisation: Schizophrenia: An international follow-up study, Wiley-New York 1979 5 ebd.

${ }^{6}$ Srinivasan, L./Tirupati, S.: Relationship between cognition and work functioning among patients with schizophrenia in an urban area of India, -in: Psychiatric Services, 56, 2005, S.1423-1428

${ }^{7}$ ebd.

8 Kinzie, D. S.: Immigrants and refugees: The psychiatric perspective, -in: Transcultural Psychiatry, 43, 2006, S.577

${ }^{9} \mathrm{ebd}$.

${ }^{10} \mathrm{ebd}$.
} 
„Jeder Fall von Schizophrenie, den ich kennenlernen durfte, enthielt - implizit oder explizit - manifeste Anzeichen der Desorientierung in einem im Wandel befindliche sozio-kulturellen Milieu“. ${ }^{11}$

\section{Ethnisches Unbewusstes und ethnische Störungen nach Georges Devereux}

Georges Devereux wurde 1908 in Ungarn geboren und ging nach Paris, um zunächst Physik und anschließend malaiische Sprachen und Ethnologie zu studieren. Nach Beendigung seines Ethnologiestudiums unternahm er zwei längere Feldforschungen in zwei Gesellschaften, die von ihm als sehr unterschiedlich beschrieben werden: bei den Sedang-Moi in Vietnam und bei den Mohave-Indianern in den USA. 1944 emigrierte er in die USA, machte eine psychoanalytische Ausbildung und praktizierte anschließend als freier Analytiker in den USA. 1963 wurde er auf den Lehrstuhl für Ethnopsychiatrie nach Paris berufen. Devereux starb 1985.

Zentral für die Entwicklung der Ethnopsychiatrie waren Devereuxs Konzepte des „ethnischen Unbewussten“ und der sogenannten „ethnischen Störungen“. Nach Devereux sind prinzipiell alle Menschen mit dem gleichen psychischen Material ausgestattet, das zu gewissen Trieben, Phantasien und anderen psychischen Manifestationen führt. Aber: ,Jede Kultur behandelt das gleiche psychische Material auf verschiedene Weise. Die eine unterdrückt es, eine andere begünstigt seine offene, manchmal sogar übermäßige Ausprägung, wieder eine andere duldet es als zulässige Alternative, sei es für alle, sei es nur bestimmte unter- oder überprivilegierte Gruppen... Die Untersuchung fremder Kulturen zwingt deshalb den Anthropologen oft, bei der Feldforschung Material zu beobachten, das er selbst verdrängt". ${ }^{12}$ Von jeder Kultur werden also bestimmte psychische Inhalte zum Bewusstsein zugelassen, während andere verdrängt werden. Dieses - von einer Kultur in Verdrängung gehaltene - Material nennt Devereux das „ethnische Unbewusste“ einer bestimmten Kultur. „Das ist der Grund, warum allen Mitgliedern ein- und derselben Kultur eine gewisse Anzahl unbewusster Konflikte gemeinsam ist. Das Material, welches das ethnische Unbewusste bildet, wird durch gewisse Abwehrmechanismen, die durch kulturelle Zwänge verstärkt und häufig durch diese bereitgestellt werden, im Zustand der Verdrängung gehalten“. ${ }^{13}$ Kultur bestimmt also nicht nur, was nicht zum Bewusstsein zugelassen wird, daher verdrängt werden muss und den Inhalt des ethnischen Unbewussten bildet, sondern die Kultur entwirft auch ein System von Abwehrmechanismen, das dem Individuum helfen soll, seine Triebe und Phantasien, die nicht mit der Kultur konform sind, in Schach zu halten. Druck erzeugt aber Gegendruck und das verdrängte Material

\footnotetext{
${ }_{11}$ Devereux, G.: Normal und anormal. Aufsätze zur allgemeinen Ethnopsychiatrie, Frankfurt/M 1982, S.196

12 Devereux, G.: Angst und Methode in den Verhaltenswissenschaften, Frankfurt/M 1988, S.67

${ }^{13}$ Devereux (1982), S.12
} 
kann wieder zum Vorschein kommen, wenn die Abwehrmechanismen nicht ausreichen, oder sich als unzuverlässig erweisen. Auch in diesem Fall bietet die Kultur Mittel an, die den Trieben wenigstens in marginaler Form Ausdruck gestatten und die es der Kultur erlauben, wieder Kontrolle über das Verdrängte zu bekommen und das sind die sogenannten „ethnischen Störungen“. Darunter versteht Devereux soziale Modelle, nach denen die Gesellschaft individuelles Fehlverhalten vorstrukturiert. Es besteht eine explizite Theorie über die Ursache und Entstehung der Störung, man hat eine genaue Vorstellung über die Symptome und über die speziellen Maßnahmen, die getroffen werden müssen, um sie zu kontrollieren. Laut Devereux bestimmt daher auch jede Kultur, was sie als „normal“ und „,anormal“ bzw. „gestört“" versteht.Beispiele für solche ethnische Störungen sind laut Devereux: „Amok"14- Attacken in Malaysien, „Imu“"15 der Ainu (indigene Bevölkerung auf der Insel Hokkaido in Japan), oder der „,Verrückte Hund der sterben will“ ${ }^{16}$ der Crow-Indianer.

Schizophrenie ist laut Devereux eine ethnische Störung der westlichen Gesellschaften, eine spezielle Orientierungsstörung in komplexen Gesellschaften. Die Schizophrenie lasse sich als Versuch interpretieren, ,sich an ein Milieu anzupassen, in dem man sich desorientiert fühlt, und die aus dieser Desorientierung resultierende Dysphorie zu neutralisieren“. ${ }^{17}$ Devereux sieht einen wesentlichen Unterschied zwischen einfachen Gesellschaften bzw. Stammeskulturen, in denen das Individuum Kenntnis über die gesamte Stammeskultur hat, während das Individuum in komplexen Gesellschaften immer nur einen beschränkten Sektor der eigenen Kultur kennen kann. Soziale Rollen, Pflichten, Zwänge, Status etc. sind in Stammeskulturen klar definiert und allen bekannt - was in modernen Gesellschaften nicht mehr der Fall ist. Gleichzeitig ist in der Symptomatik der Schizophrenie festgelegt, wie sich jemand zu verhalten hat, der damit nicht zurecht kommt, und ,verrückt wird“.

\section{Die Beschreibung des Gruppen-Ich von Paul Parin}

Einen weiteren wichtigen Beitrag zur Entwicklung der transkulturellen Psychiatrie lieferten die Arbeiten der in Zürich weiterentwickelten Ethnopsychoanalyse - vor allem von Paul Parin und Goldy-Parin-Matthèy. Sie fuhren in den 60er Jahren nach Afrika und untersuchten zwei Gesellschaften, die Dogon in Mali und die Agni in

\footnotetext{
${ }^{14}$ Eine „Amok“-Attacke bezeichnet eine willkürliche, offenbar nicht provozierte Episode mörderischen oder erheblich zerstörerischen Verhaltens, die nach Devereux von einem Malaien mit einem speziellen Spieß - dem Kris - ausgeführt wird.

15 „Imu“ bezeichnet eine Störung, bei der der Betreffende nach einem Schreck unpassende, obszöne Wörter schreit mit absurden körperlichen Reaktionen und/oder zwanghaft Wörter, Bewegungen und Gesten seiner Mitmenschen nachahmt (Echolalie und Echopraxie).

16 Der „Verrückte Hund der sterben will der Crow-Indianer“ bezeichnet einen Crow, der in selbstmörderischer Absicht ohne Waffen auf das Schlachtfeld läuft.

${ }_{17}$ Devereux (1982), S.200f.
} 
der Elfenbeinküste, indem sie mit den Menschen psychoanalytische Gespräche führten. Ähnlich wie EthnologInnen teilnehmende Beobachtung durchführen und zusätzlich einheimische Informanten befragen, betrieben Parin und Parin-Matthèy teilnehmende Beobachtung - vor allem der Erziehungs- und Sozialisationspraktiken - und führten mit ihren „InformantInnen“ psychoanalytische Gespräche. ${ }^{18}$ Dabei wichen sie vom klassischen psychoanalytischen Setting ab, d.h. die KlientInnen lagen nicht auf der Couch, sondern saßen neben dem/der AnalytikerIn. Die KlientInnen wurden bezahlt - mit einem ähnlichen Stundenlohn, wie ihn die Verwaltung den Vorarbeitern beim Straßenbau zahlte. Die Gespräche wurden auf Französisch geführt und die KlientInnen wurden einfach ermutigt, zu erzählen, was ihnen so durch den Kopf ging.

Die Dogon in Mali wurden von Parin und Parin-Matthèy vor allem deshalb ausgewählt, weil sie eine ethnologisch sehr gut untersuchte Gesellschaft waren. Sie waren Subsistenzbauern und produzierten Hirse, Zwiebel, Tabak. Sie lebten in der Steppe, waren patrilinear (d.h. die Verwandtschaft des Kindes wurde über die väterliche Linie definiert) und patrilokal (die Frau des Mannes zog zu ihm und dem patrilinearen Klan) organisiert. Als Ideal galt ein Mann mit zwei Frauen. Damals waren die Dogon auch nicht islamisiert und hatten einen höchsten Gott „Amma“. In den psychoanalytischen Gesprächen haben Parin und Parin-Matthèy vor allem versucht, die vorherrschenden Abwehrmechanismen herauszuschälen. Dabei zeigte sich, dass ihre GesprächspartnerInnen sich immer dann wohler fühlten, wenn sie nicht alleine mit dem/der AnalytikerIn sprachen, sondern wenn auch noch andere Dogon dazukamen. Laut Parin und Parin-Matthèy löste die Konzentration der Gefühle auf eine einzige Person Angst aus und die Haupterledigungsform von Konflikten war dementsprechend die „Verteilung auf die Gruppe“. Die dazu dienlichen Abwehrmechansimen der wechselseitigen Identifikation und Projektion würden laut Parin auch ständig von den Gruppenmitgliedern angewandt. Die Ergebnisse aus den psychoanalytischen Gesprächen wurden ergänzt durch Beobachtungen der typischen Erziehungsmuster. In der ersten Entwicklungsphase des Kindes von der Geburt bis zur Abstillung bestehe eine enge Symbiose zwischen Mutter und Kind, das Kind erleide kaum Versagungen, es würde überallhin mitgetragen und es bestehe prinzipiell ein enger Körperkontakt. Diese Phase dauert laut Parin sehr lang - bis zum 3. Lebensjahr, dann würde das Kind von einem Tag auf den anderen radikal abgestillt und der Obhut der anderen Geschwister und generell auch der anderen Gruppenmitgliedern überlassen. Von da an hat das Kind „viele kleine Mütter“. Durch dieses Erziehungsmuster würde den Dogon auch eine bestimmte Art der Konfliktlösung nahe gelegt, nämlich eben die sogenannte „Verteilung auf die Gruppe“. Laut Parin erzeugt seit der radikalen Abstillung die Zentrierung der Gefühle auf eine einzige Person Angst, diese wird durch identifikatorische Beziehungen innerhalb der Gruppe gemieden. Parin nennt diese Form der

18 vgl. Parin, P./Morgenthaler, F./Parin-Matthèy, G.: Die Weißen denken zuviel. Ethnopsychoanalytische Gespräche bei den Dogon in Westafrika, München 1972 
Ich-Struktur das „Gruppen-Ich, das auf wechselseitige Identifikationen aller Gruppenmitglieder angewiesen ist. D.h. die Dogon benötigen die Struktur des Gesellschaftsgefüges für das innere Gleichgewicht. Das Selbstgefühl ist vom Zusammenhalt der Gruppe abhängig. In gewohnter Umgebung sind sie frei von Angst und Schuldgefühl, unter Fremden sind sie unsicher, fühlen sich ausgestoßen und verloren. Dass dieses Gefühl über ein übliches Unsicherheitsgefühl unter Fremden hinausgeht, zeigt folgendes Zitat. Paul Parin hatte mit einem Dogon namens Dommo viele Gespräche geführt, als sie einmal gemeinsam beschlossen, in die Hauptstadt Mopti zu fahren, wo Dommo noch nie gewesen war: „Dommo ist ein Pflanzer. Er ist an sein Dorf und an den Boden, den er bearbeitet, gebunden. Er ist kein Nomade wie die Peul. Auf seiner Reise nach Mopti fühlte er sich verloren und heimatlos ... Er fühlte sich aus seiner gewohnten Umgebung herausgerissen, die für ihn mehr bedeutete als Vertrautheit und Geborgenheit ... Dommo war in Mopti nicht bloß eingeschüchtert und unsicher ... Dommo erlitt einen Stupor. Er war vorübergehend in seiner Persönlichkeit krankhaft verändert ... Er erlebte einen Identitätsverlust, der so weit ging, dass er nicht mehr imstande war, das elementare Bedürfnis des Durstes selbständig zu stillen und sich in den Schatten zu setzen“. ${ }^{19}$

Das „Gruppen-Ich“ wird also von Paul Parin zusammenfassend wie folgt beschrieben: Es bezeichnet eine bestimmte Funktionsweise des Ich, die auf die Mitwirkung einer Gruppe von Menschen angewiesen ist, die eine bestimmte psychische Struktur aufweisen und in besonderer Weise reagieren müssen. „Ihre emotionelle Bereitschaft und/oder ihre Fähigkeit ganz bestimmte Rollen zu übernehmen, ist die Voraussetzung dafür, dass das Gruppen-Ich in Funktion tritt. Diese Ichfunktionen beruhen auf der erworbenen Bereitschaft des Ich, ganz bestimmte identifikatorische Beziehungen einzugehen". ${ }^{20}$

Parin beschreibt das Gruppen-Ich als durchaus gesunde Ich-Struktur, bei der die Abhängigkeit von der Gruppe zwar größer ist als in westlichen Gesellschaften, aber erst bei Entfernung von der Gruppe psychische Störungen - wie bei Dommo in Mopti - entstehen können. Damit widerspricht Parin gängigen Grundsätzen der westlichen Psychologie, die ein abgegrenztes autonomes Selbst als Voraussetzung für psychische Gesundheit definiert. Die Idealisierung des abgegrenzten Selbst zieht sich durch sämtliche Konzepte der westlichen Psychologie: wie z.B. das Konzept der individuellen, persönlichen, von anderen unabhängigen Identität, die nach Selbstverwirklichung, dem „wahren Selbst“ strebt, ${ }^{21}$ eine „interne Kausalattribuierung ",22 die die Übernahme persönlicher Verantwortung für das eigene Leben - im positiven wie im negativen Sinn - bedeutet und schließlich auch Kohl-

\footnotetext{
19 Parin/Morgenthaler/Parin-Matthèy (1972), S.462

20 Parin, P.: Der Widerspruch im Subjekt, Frankfurt/M 1978, S.88

21 Maslow, A. H.: Motivation and Personality, New York 1954

22 Rotter, J.: Generalised expectancies for internal versus external control of reinforcement, -in: Psychological Monographs, 80, 1966 (Whole No. 609)
} 
bergs (1964) ${ }^{23}$ Entwicklungsstufen des moralischen Urteils. Diesem Konzept zufolge kommt das Individuum auf der (höchsten) Stufe im „,postkonventionellem Stadium“ zum selbständigen, von eigenen Überzeugungen bestimmten Urteil über verhaltensleitende Normen. Wenn also Personen etwa keine unabhängige persönliche Identität haben, vielleicht nicht nach individueller Selbstverwirklichung streben, oder ihr Lebensglück ausschließlich von äußeren Umständen abhängig sehen und auch keine anderen Wertmaßstäbe moralischen Urteilens haben als die Gruppennorm, werden sie nach westlichen Gesichtspunkten mit Psychopathologie in Zusammenhang gebracht. Die Idealisierung des abgegrenzten autonomen Selbst gehört also zu unserer ureigensten tiefen kulturellen Prägung im Westen, die unsere Richtlinien von „normal“ und „,anormal“ ganz entscheidend bestimmt.

\section{Westliche Psychologien und indigene Psychologien}

Unterschiede zur ursprünglich als universell gedachten westlichen Psychologie und Psychoanalyse haben PsychologInnen aus verschiedensten Teilen der Welt mit der Entwicklung sogenannter ,indigener Psychologien“ gezeigt. Ihnen zufolge ist auch die westliche Psychologie keine universelle, sondern ebenfalls eine ,indigene“ Psychologie. In Indien wurde z.B. die in der westlichen Psychologie häufig beschriebene anfängliche „Mutter-Kind-Dyade“ als „universale Kategorie“ in Frage gestellt: „Kurtz is able to conclude from several research studies with Indian children $^{24}$ that there is evidence of ,more frequent emotional interaction with the group than between child and the mother ${ }^{62}$... In Indian homes, there is an absence of exclusive face to face mirroring between the mother and her child that we read in western literature“. ${ }^{26}$ „Kurtz (1992) ... for example, argues that this break of a special exclusive bond with the mother is strictly associated with the vital role of social participation within Indian society ... The family is usually an extended family, and contact between neighbours seems quite common, leading the child to be in constant social interaction". 27

Ramanujan (1983) und nach ihm Obeyesekere (1990) ${ }^{28}$ haben aus psychoanalytischer Perspektive die zum Westen unterschiedliche ödipale Konstellation in In-

\footnotetext{
${ }^{23}$ Kohlberg. L.: Development of moral character and moral ideology, -in: Hoffman, M. L./Hoffman, L. W. (Hrsg.): Review of child development research, Vol.1, New York 1964, S.381-431

${ }^{24}$ Dube, S. C.: Indian village, London: Routledge \& Kegan Paul 1955; Seymour, S.:, Patterns of childrearing in a changing Indian town, Havard University 1971 (unpublished doctoral dissertation)

${ }^{25}$ Kurtz, S.: All the mothers are one: Hindu India and the cultural reshaping of psychoanalysis, New York 1992, p. 80

26 Chaudhary, N: Listening to culture: Constructing reality from everyday talk, New Delhi 2004, p.112, zit. nach Salgado, J.: Listening to India, listening to ourselves: the place of self in culture, -in: Culture \& Psychology, 2006, 12, p.105

${ }^{27}$ Salgado (2006), S.105f.

${ }^{28}$ Die psychoanalytischen Ansätze von Ramanujan, Obeyesekere und auch Kakar (siehe weiter unten) können nicht als indigene Psychologien im engeren Sinne bezeichnet werden, weil sie auf westlichen psychoanalytischen Konzepten aufbauen. Gleichzeitig beziehen sie sich aber auf „indigene“ indische
} 
dien beschrieben. Die ödipale Krise wird nach Ramanujan durch Unterwerfung des Sohnes unter den Vater und nicht durch Identifikation mit ihm gelöst. Ramanujan betonte, dass in Hindu-Epen im Gegensatz zum griechischen ÖdipusMythos viel öfter das Motiv das „Sohnmordes“ als des „Vatermordes“ auftauche:

"Ramanujan noted the virtual absence of patricide in the Indian Oedipus; rather the brunt of literally hundreds of myths and folktales are focused on the killing of the son by the father". ${ }^{29}$ "The son must submit to the father; by submission the son has the father's love and forgiveness ... Identification through submission ... this is the dominant (metaphorically "killing") of the father. It is a mechanism of defense specific to Hindu society, permitting the son to introject the parental value system and simultaneously resolve the Oedipal crisis". ${ }^{30}$ "The focus is on the welfare of the patrilineal joint family and the larger institutions of the society - caste and the political order - that together conspire to suppress individualism (if not individuality) in the interests of the collectivity ... In this situation, the unity of the joint family ... rests on two axes of social control - the affective ties binding the individual on his family through the nurturant and erotic dependency of the son on the mother continuing into adulthood; and the patripotestal authority of the father, the repository of the religiously based values of the Hindu family and larger society. Thus the emotional relationship in the family are linked to the suppression of individualism, the unity of the joint family and larger supra-national structures such as caste, and the religious values on which these are grounded". 31

In der kulturvergleichenden Psychologie haben Markus und Kitayama (1991) interkulturelle Unterschiede in Selbstkonzepten mit den Begriffen ,independent self“ und „interdependent self“" bezeichnet. ${ }^{32}$ Das ,independent self“" wird als abgegrenztes, autonomes Selbst mit stabilen Eigenschaften beschrieben, das ,interdependent self" als sozial abhängiges, relationales Selbst, mit dementsprechenden variablen „Eigenschaften“, die vom sozialen Kontext abhängen. So lassen sich Personen mit einem ,interdependenten Selbstkonzept" in ihrem Verhalten mehr durch kontextuelle Faktoren beeinflussen. ${ }^{33}$ Werden sie aufgefordert, sich selbst zu beschreiben, haben sie dabei oft Schwierigkeiten, wenn sie nicht auch den Kontext

Ressourcen, wie Hindu-Epen, Mythologien, Filme etc. und relativieren die westlichen Ansätze. Vgl. Ramanujan, A. K.: The Indian Oedipus, -in: Edmunds, L./Dundes, A. (ed.): Oedipus. A Folklore Casebook, New York 1983; Obeyesekere, G.: The work of culture. Symbolic transformation in psychoanalysis and anthropology, Chicago 1990

${ }^{29}$ Obeyesekere (1990), S.77

30 ebd., S.85

31 ebd., S.83

32 Markus, H. R./Kitayama, S.: The cultural psychology of personality, -in: Journal of Cross-Cultural Psychology, 29, 1, 1998, S.63-87

33 Singelis, T. M./Brown, W. J.: Culture, self, and collectivist communication: Linking culture to individual behavior, -in: Human Communication Research, 1995, 21, S.354-89 
ihrer Handlungen beschreiben können. Cousins ${ }^{34}$ ließ z.B. AmerikanerInnen und JapanerInnen sich selbst beschreiben, und verwendete dabei den Twenty Statements Test (TST). Die Probanden sollten zwanzig Antworten auf die Frage „Wo am I?" geben. Es stellte sich dabei heraus, dass sich AmerikanerInnen viel mehr mit generalisierten Persönlichkeitsattributen beschrieben, während sich JapanerInnen besser beschreiben konnten, wenn sie auf den Kontext Bezug nahmen, in dem sie auf eine bestimmte Art handelten:

"Cousins concluded that the Americans' need to preserve an independent, context-free self-concept led them to assert that although they might behave in a certain way in a particular setting, this would not necessarily reflect their 'real' self ... The Japanese respondents, on the other hand, show that they are better able to characterise themselves when the nature of their interdependence is specified". 35

Sowohl die eigene Person wird kontextabhängiger gesehen, als auch die anderen Menschen, wie die Ergebnisse von Miller (1984) zeigen. ${ }^{36}$ In dieser Studie wurden AmerikanerInnen und InderInnen verglichen, wie sie andere Personen beschreiben: die AmerikanerInnen benutzten hierfür wesentlich mehr EigenschaftsZuschreibungen, während die InderInnen mehr kontextgebundene Zuschreibungen machten. Inzwischen ist noch eine dritte Form des Selbstkonzeptes beschrieben worden, das ,autonom-relationale Selbst“"37 und die einseitige Zuschreibung eines individualistischen, autonomen Selbst für westliche Kulturen in Frage gestellt worden. So betont Greenfeeld (2000) etwa, dass jede Kultur einen Weg finden muss, die Beziehung zwischen Individuum und Gruppe zu gestalten. ${ }^{38}$ Nichts desto trotz spielt die Diskussion eines „relationalen (d.h. inderdependenten) Selbst“ im Bereich indigener Psychologien - insbesonderer asiatischer indigener Psychologien - nach wie vor eine herausragende Rolle. ${ }^{39}$

\footnotetext{
34 Cousins, S.: Culture and selfhood in Japan and the US, -in: Journal of Personality and Social Psychology, 56, 1989, S.124-31, zit. nach Smith, P. B./Bond, M. H.: Social Psychology across Cultures, Harlow 1998, S.106f.

35 Smith/Bond (1998), S.107

36 Miller, J. G.: Culture and the development of everyday social explanation, -in: Journal of Personality and Social Psychology, 46, 1984, S.961-78

${ }^{37}$ Smith, P. B./Bond, M. H./Kagitçibaşi, Č.: Understanding social psychology across cultures, London 2006, S.109

38 Greenfeeld, P. M.: Three approaches to the psychology of culture: Where do they come from? Where can they go? -in: Journal of Social Psychology, 3, 2000, S.223-240

39 vgl. Kim, U./Yang, K.-S./Hwang, K.-K.: Indigenous and Cultural Psychology. Understanding People in Context, New York 2006
} 


\section{Die Beschreibung der Ich-Struktur im hinduistischen Indien nach Kakar}

Der indische Psychoanalytiker Kakar $(1980,1981)^{40}$ beschäftigte sich mit dem Vergleich der psychischen Organisation im Westen und im hinduistischen ${ }^{41}$ Indien: Ihm zufolge bestehe der wesentlichste Unterschied zwischen den Menschen im Westen und im hinduistischen Indien darin, dass in Indien eine psychische Weiterentwicklung gerade darin gesehen wird, der „Ich-Entwicklung“ im westlichen Sinne entgegen zu wirken. Nach dieser Auffassung ist das „Ich-Bewusstsein“ falsch, es ist „maya“ - Täuschung. Das richtige Bewusstsein ist „vidya“, in dem die Grenzen zwischen Ich und Nicht-Ich aufgehoben sind. Dieser Zustand wird als „höchster Sinn des Menschen“ bezeichnet und ist erst dann erreicht, wenn die Empathie mit dem Anderen zur vollständigen Identifikation wird, zum Empfinden des „Selbst“ auch im Anderen. Für die hinduistische Religiosität bezeichnet Kakar das Streben nach „moksha“, d.h. die Suche nach Vereinigung von Ich und NichtIch, als wichtigstes Motiv. „Moksha“ stellt eine direkte Erfahrung von der fundamentalen Einheit des Menschen mit dem Unendlichen dar und befreit letztendlich von allem Irdischen.

„Die Upanishaden, die dieses Motiv der vollkommenen Vereinigung ausführlich behandeln, beschreiben diesen Zustand in metaphorischer, ja leidenschaftlicher Sprache: Wie ein Mensch in der Umarmung seines Geliebten kein Bewusstsein von außen und innen hat, so bleibt in dieser Erfahrung nichts zurück als Hinweis auf innen und außen. Es ist der Eintritt ins brahman, ein Verschmelzen mit brahman, Verzehren des brahman, Atmen des brahman. Es ist die Einheit von Selbst und Welt". ${ }^{42}$

Kakar betont darüber hinaus, dass die Idee des mokśa nicht nur marginale Bedeutung hat, sondern einen zentralen Stellenwert im Leben jedes/r Hindu darstellt. Jede Studie über das hinduistische Indien muss sich seiner Meinung nach mit diesem Phänomen auseinandersetzen, auch wenn das aus westlicher Sicht schwierig und irritierend sein mag.

Mit anderen Worten hebt Chaudhary die Abwertung der „Selbst-Zentriertheit“ in der hinduistischen Religiosität hervor: "Atman is the element of life that remains unchanged and is the knower, or the self as a subject, the real, I' ... The experiences of the sentient self are seen as illusory and inconsequential of true happiness and a

\footnotetext{
${ }^{40}$ Kakar, S.: The inner world: A psychoanalytic study of childhood and society in India, Delhi: Oxford University Press, 1981; Kakar, S.: Kindheit und Gesellschaft in Indien, Frankfurt/M 1988

${ }^{41}$ Unter „Hinduismus“ wäre eher eine Gruppe von Religionen als eine singuläre Religion zu verstehen, und der Begriff ist ein Konstrukt der ehemaligen britischen Kolonialverwaltung. Er ist aber inzwischen auch für Hindus zur Realität geworden (vgl. King, R.: Orientalism and Religion: Postcolonial Theory, India and the Mysthic East, New Delhi 1999), und bezeichnet im Allgemeinen eine transnationale Gemeinschaft, die aus in Indien lebenden Personen und der Diaspora besteht (vgl. Schmidt, B.: Einführung in die Religionsanthropologie, Berlin 2008, S.169

${ }^{42}$ Kakar (1988), S.27
} 
meaningful life. Thinking too much about the self, i.e., the empirical self is believed to lead to ahankara or undesirable pride". ${ }^{43}$

\section{Das „Ich-Bewusstsein“ in der buddhistischen Psychologie}

Chakkarath (2007) beschreibt das „Ich-Bewusstsein“ in der buddhistischen Psychologie folgendermaßen: Es werden 18 Elemente unterschieden: sechs Sinnesorgane (Augen, Nase, Ohren, Zunge, Körper, Geist), sechs Sinnesobjekte (Aussehen, Geruch, Ton, Geschmack, Berührung und Geistobjekt) und sechs Bewusstseinsarten von den sechs Sinnesorganen und den ihnen entsprechenden Sinnesobjekten. „Jeder geistige Vorgang, wie auch jedes begleitende, vorangehende oder nachfolgende geistige Phänomen kann so, unter Berücksichtigung der jeweils vorliegenden Körperfaktoren, als spezifische Kombination dieser Elemente untereinander und mit den von ihnen erzeugten Wahrnehmungs- und Willensphänomenen beschrieben werden“. ${ }^{44}$ Das „Selbst“ ist eine Illusion, nämlich das Resultat eines kontinuierlichen Erzeugungs- und Vergehensprozesses. Demnach gibt es in der buddhistischen Psychologie keine zeitlich überdauernde personale Identität. ${ }^{45}$

Die erwähnten unterschiedlichen Selbstkonzepte und Formen von IchBewusstsein beeinflussen natürlich die Kategorien von Gesundheit und Krankheit insbesondere im psychiatrischen Bereich, so dass eine Übertragung westlicher Psychiatrie-Diagnoseschemata auf andere kulturelle Bereiche äußerst fragwürdig erscheint. In den USA und Europa wird von PsychiaterInnen häufig das Diagnostic and Statistical Manual of Mental Disorders (DSM), benutzt, ein Klassifikationssystem der American Psychiatric Association. Inzwischen gibt es Ausgaben in vielen Ländern, unter anderem eine deutsche Publikation der vierten Version (DSM-IV). ${ }^{46}$ Seit der dritten Version des DSM werden psychiatrische Diagnosen in fünf Achsen systematisiert, d.h. bei jeder Diagnose soll der Zustand auf jeder der fünf Achsen eingeschätzt werden. Diese Achsen sind:

1. Klinische Störungen,

2. Persönlichkeitsstörungen,

3. medizinische Krankheitsfaktoren (körperliche Probleme)

4. Psychosoziale und umgebungsbedingte Probleme und

5. Funktionsniveau (soziale Anpassung, Arbeitsfähigkeit etc.).

\footnotetext{
${ }^{43}$ Chaudhary (2004), S.129f.

${ }^{44}$ Chakkarath, P.: Kulturpsychologie und indigene Psychologie, -in: Straub, J./Weidemann,

A./Weidemann, D. (Hrsg.): Handbuch interkulturelle Kommunikation und Kompeten₹: Grundbegriffe - Theorien - Anwendungsfelder, Stuttgart 2007, S.237-248, S.246

45 ebd.

${ }^{46} \mathrm{Saß}$, H. et al.: Diagnostisches und Statistisches Manual Psychischer Störungen - Textrevision - DSM-IV-TR, Göttingen 2003
} 
Eine Arbeitsgruppe von renommierten Medizinanthropologen an der Harvard Universität ${ }^{47}$ hat sich mit der Frage der Reformierung des DSM beschäftigt, um den implizit im DSM enthaltenen Ethnozentrismus zu überwinden. Globalisierung und Migration machen eine Einbeziehung europäischer und außereuropäischer Kulturen in psychologisch-medizinische Fragestellungen notwendig und stellen die absolute Vergleichbarkeit und universalistische psychiatrische Diagnosen in Frage. Die Empfehlungen der Arbeitsgruppe an der Harvard Universität zur Reformierung des DSM-IV bestanden darin, das Achsensystem zu erweitern und zu den fünf Achsen eine sechste Kulturachse hinzuzufügen. Diese Kulturachse würde es ermöglichen, jede psychiatrische Diagnose auch in ihrem kulturellen Kontext hin zu analysieren und bewerten. Darüber hinaus entwarfen sie einen „Leitfaden zur Beurteilung kultureller Einflussfaktoren und ein Glossar kulturabhängiger Syndrome" und empfahlen diesen gleich an den Beginn des DSM zu stellen. Leider entschieden sich die HerausgeberInnen des DSM-IV gegen die Empfehlungen der Harvard-Arbeitsgruppe, führten keine separate Kulturachse ein und verlagerten den Leitfaden und das Glossar kulturabhängiger Syndrome in den Anhang der Publikation - um die universalistische Position des DSM nicht zu gefährden. Das Ergebnis - das DSM IV - entspricht also immer noch dem Anspruch eines universal gültigen psychiatrischen Diagnoseschemas, mit ein paar Ausnahmen - ein paar culture bound syndromes im Anhang. ${ }^{48}$ Der Vorschlag der Arbeitsgruppe hingegen, eine eigene Kulturachse einzuführen und jede Diagnose auch auf der Kulturachse zu analysieren, entspricht der Denkweise einer aus der Ethnopsychoanalyse entstandenen Richtung der Transkulturellen Psychiatrie, die tatsächlich einen groBen Beitrag zur interkulturellen Verständigung leisten kann und insbesondere im Rahmen der Migration von großer Bedeutung ist. Eine Diagnose auf der Kulturachse beinhaltet die Analyse der Erklärungsmuster, die von den KlientInnen selbst benutzt werden. Das möchte ich anhand von Beispielen (Wohlfart/Özbek 2006 und Wohlfart/Hodzic/Özbek 2006) ${ }^{49}$ erläutern: Eine Migrantin zweiter Generation in Deutschland mit Eltern aus der Türkei klagt über eine Besessenheit durch Geister, was ihr zunächst eine Schizophrenie-Diagnose einbringt. Im Rahmen einer aufdeckenden Psychotherapie wird zunächst deutlich, dass sie zur Erklärung ihrer Symptomatik auf ein ihr kulturell vertrautes und erstmalig von einem Hoca (einem türkischen „Heiler") diagnostiziertes Erklärungsmuster („Besessenheit durch Geister") zurückgreift. Desweiteren gelingt es in der Psychotherapie durch die konsequente Deutung der Geister als abgespaltene und verdrängte Gefühle und Bedürfnisse auch zunehmend, dass die Patientin ihre eigenen Bedürfnisse

\footnotetext{
${ }^{47}$ Fabrega, H./Mezzich, J. E./Kleinman, A. (ed.): Culture and Psychiatric Diagnosis: A DSM-IV Perspective, Washington 1996

48 Wohlfart E./Hodzic, S.,/Özbek, T.: Transkulturelles Denken und transkulturelle Praxis in der Psychiatrie und Psychotherapie, -in: Wohlfart, E./Zaumseil, M. (Hrsg.) Transkulturelle Psychiatrie Interkulturelle Psychotherapie, New York 2006, S.143-153

49 Wohlfart/Hodzic/Özbek (2006); Wohlfart, E./Özbek, T.: Die Suche nach offenen Türen. Eine ethnopsychoanalytische Kasuistik über das Phänomen der Besessenheit, -in: Psyche, 60, 2006, S.118130
} 
wahrnehmen und verbalisieren kann. ${ }^{50}$ In der Religionsanthropologie sind die rebellischen und subversiven Elemente von Besessenheitsphänomenen bereits intensiv diskutiert worden. ${ }^{51}$ Das Verhalten von den von Geistern „Besessenen“ gilt oft als sozial entschuldigt. Die Betroffenen tun und sagen Dinge, die ihnen im „gesunden“ Zustand vielfach verwehrt sind und für die sie im Zustand der „Besessenheit" nicht verantwortlich gemacht werden. ${ }^{52}$ Die Schizophrenie-Diagnose stellt in diesem Fall also nicht nur eine inadäquate Diagnose dar, sondern hätte es der Patientin auch weiterhin nicht ermöglicht, sich mit ihrer Symptomatik auseinanderzusetzen.

Ein weiteres Beispiel: „Ein afrikanischer Mann mittleren Alters mit perfekten Deutschkenntnissen, der seit zwanzig Jahren in Deutschland lebt, stellt sich notfallmäßig in einer Klinik vor. Er berichtet dem zugezogenen Psychiater, seine Mutter habe bei ihrer Rückkehr nach Afrika seine Seele mitgenommen und versuche ihn zu zerstören“.53 Das Phänomen des „Seelenverlustes“ oder „Seelenraubes“ ist ebenfalls in vielen Kulturen ein durchaus übliches Erklärungsmuster für eine psychologische Symptomatik. Die Erklärung ist nicht weniger rational als die eines österreichischen Mannes, der etwas eine ähnliche Symptomatik als „Depression“ definiert. Beide Definitionen sind Rückgriffe auf vertraute Erklärungsmuster die auch kulturell vermittelt sind. Für die Exploration in der Psychotherapie ist es besonders wichtig, gerade diesen kulturellen Kontext des Erklärungsmusters zu erheben: Was gilt als Ursache und wie wird die Symptomatik üblicherweise behandelt etc.? Diese Informationen geben wichtige Hinweise darauf, warum ein/e PatientIn eine bestimmte Symptomatik entwickelt. Im obigen Beispiel konnte durch die Exploration des Erklärungsmusters und eine aufdeckende Psychotherapie auf die Ambivalenz des Mannes gegenüber seiner Mutter eingegangen werden. Der Mann lebt seit zwanzig Jahren in Deutschland, die Mutter nach wie vor in Afrika. Als sie nach ihrem Besuch Deutschland wieder verlässt, behält der Patient sie „,bei sich“, indem er eine Symptomatik entwickelt, mittels derer er sich auch nach Abreise der Mutter noch intensiv mit ihr beschäftigt: „Er habe nachts oft Alpträume, die ihn quälen, meist sehe er seine Mutter und ihre Schwestern im Schlaf. Sie fesseln ihn im Traum an Armen und Beinen und führen spirituelle Rituale durch“.54

\footnotetext{
50 Wohlfart/Özbek (2006)

${ }^{51} \mathrm{vgl}$. Lewis. I. M.: Ecstatic religion, an anthropolopgical study of spirit posession and shamanism, London ${ }^{3} 2003$; Boddy, J.: Wombs and alien spiritis: women, men and the Zar cult in Northern Sudan, Madison 1989

52 Damit bietet die Besessenheit eine Möglichkeit, Normen und Tabus zu brechen. Trotzdem beinhaltet die Artikulation verdrängter Gefühle und Bedürfnisse in Form von „Geistern“ auch ein „Verbot“ und dient letztendlich der Aufrechterhaltung der gesellschaftlichen Ordnung (vgl. auch Reif, E.: Ethnopsychoanalytische Aspekte der Geschlechterbeziehungen im Islam, Diss. Universität Wien, Wien 1995; Strasser, S.: Die Unreinheit ist fruchtbar! Grenzüberschreitung en in einem türkischen Dorf am Schwarzen Meer, Wien 1995; Strasser, S.: Krise oder Kritik? Zur Ambiguität von weiblicher Besessenheit als translokale Strategie, -in: Wohlfart, E./Zaumseil, M. (Hrsg.) Transkulturelle Psychiatrie - Interkulturelle Psychotherapie, New York 2006, S.299-311

53 Wohlfart/Hodzic/Özbek (2006), S.161

54 ebd.
} 
Die oben illustrierte spezielle Arbeitsweise in der Transkulturellen Psychiatrie wurde im Centre Georges Devereux entwickelt, das 1993 von einem Schüler von Georges Devereux - Tobie Nathan - in Paris gegründet wurde. Neben Forschung und Lehre wird in diesem Zentrum Ethnopsychotherapie angeboten. Das spezifisch ethnopsychiatrische Setting besteht aus einer interdisziplinären und insbesondere mehrsprachig plurikulturellen Therapeutengruppe. In jedem Setting ist mindestens ein/e sogenannte/r ,MediatorIn“ - eigentlich ein/e kulturelle/r ÜbersetzerIn dabei, der/die mit den Kulturen der PatientInnen vertraut ist und die auch von den PatientInnen angewandten Erklärungsmuster für ihre Symptomatik kulturell übersetzen kann, d.h. das Erklärungsmuster wird in einem kulturellen Kontext eingebettet analysiert und „übersetzt“. 55

Zum Abschluss sei hier noch erwähnt, dass sich nicht jede als „Transkulturelle Psychiatrie“ bezeichnende Disziplin auf die Ethnopsychoanalyse stützt, so dass sich diese Ausführungen also auf eine spezielle Richtung in der Transkulturellen Psychiatrie beziehen, welche sich - wie in diesem Artikel gezeigt - aus einem bestimmten historischen Kontext heraus entwickelt hat und auch einen speziellen therapeutischen Ansatz impliziert.

\section{Literatur}

Bhatia, S.: Reinterpreting the inner Self in Global India: ,Malevolent mothers', ,Distant fathers' and the development of children's identity, -in: Culture and Psychology, 12, 2006, pp.378-392

Chakkarath, P.: Kulturpsychologie und indigene Psychologie, -in: Straub, J./Weidemann, A./Weidemann, D. (Hrsg.): Handbuch interkulturelle Kommunikation und Kompetenz. Grundbegriffe - Theorien - Anwendungsfelder, Stuttgart: Metzler 2007, S.237-248

Cousins, S.: Culture and selfhood in Japan and the US, -in: Journal of Personality and Social Psychology, 56, 1989, S.124-31

Devereux, G.: Ethnopsychoanalyse. Die komplementaristische Methode in den Wissenschaften vom Menschen, Frankfurt/M: Suhrkamp 1978

Devereux, G.: Normal und anormal. Aufsätze zur allgemeinen Ethnopsychiatrie, Frankfurt/M: Suhrkamp 1982

Devereux, G.: Angst und Methode in den Verhaltenswissenschaften, Frankfurt/M: Suhrkamp 1988

Dube, S. C.: Indian village, London: Routledge \& Kegan Paul 1955

55 vgl. Felici-Bach, H.: Die therapeutische Arbeit mit einem Mediator in einem ethnopsychiatrischen Setting - eine Herausforderung an unsere klinische „Weltanschauung“, -in: Wohlfart, E./Zaumseil, M. (Hrsg.): Transkulturelle Psychiatrie - Interkulturelle Psychotherapie, Heidelberg 2006, S.127-136 
Chaudhary, N: Listening to culture: Constructing reality from everyday talk, New Delhi: Sage 2004

Fabrega, H./Mezzich, J. E./Kleinman, A. (ed.): Culture and Psychiatric Diagnosis: A DSM-IV Perspective, Washington: American Psychiatric Press 1996

Greenfeeld, P. M.: Three approaches to the psychology of culture: Where do they come from? Where can they go? -in: Journal of Social Psychology, 3, 2000, S.223240

Kakar, S.: The inner world: A psychoanalytic study of childhood and society in India, Delhi: Oxford University Press, 1981

Kakar, S.: Kindheit und Gesellschaft in Indien, Frankfurt/M 1988

Kim, U./Yang, K.-S./Hwang, K.-K.: Indigenous and Cultural Psychology. Understanding People in Context, New York: Springer 2006

King, R.: Orientalism and Religion: Postcolonial Theory, India and the Mysthic East, New Delhi: Oxford University Press 1999

Kinzie, D. S.: Immigrants and refugees: The psychiatric perspective, -in: Transcultural Psychiatry, 43, 2006

Kohlberg. L.: Development of moral character and moral ideology, -in: Hoffman, M. L./Hoffman, L. W. (Hrsg.): Review of child development research, Vol.1, New York 1964, S.381-431

Kraepelin, E.: Psychiatrisches aus Java, -in: Centralblatt für Nervenheilkunde und Psychiatrie, Bd. 15, 1904, 27, S.468-496

Kurtz, S.: All the mothers are one: Hindu India and the cultural reshaping of psychoanalysis, New York: Columbia University Press 1992

Lewis, I. M.: Ecstatic religion, an anthropolopgical study of spirit posession and shamanism, Harmondsworth: Penguin1971

Markus, H. R./Kitayama, S.: Culture and the self: Implications for cognition, emotion and motivation, -in: Psychological Review, 1991, 98, S.224-253

Markus, H. R./Kitayama, S.: The cultural psychology of personality, -in: Journal of CrossCultural Psychology, 29, 1, 1998, S.63-87

Maslow, A. H.: Motivation and Personality, New York 1954

Miller, J. G.: Culture and the development of everyday social explanation, -in: Journal of Personality and Social Psychology, 46, 1984, S.961-978

Obeyesekere, G.: The work of culture. Symbolic transformation in psychoanalysis and anthropology, Chicago: University of Chicago Press 1990 
Parin, P./Morgenthaler, F./ Parin-Matthèy, G.: Die Weißen denken zuviel. Ethnopsychoanalytische Gespräche bei den Dogon in Westafrika, München 1972

Parin, P.: Der Widerspruch im Subjekt, Frankfurt/M 1978

Ramanujan, A. K.: The Indian Oedipus, -in: Edmunds, L./Dundes, A. (ed.): Oedipus, A Folklore Casebook, New York: Garland 1983

Reif, E.: Ethnopsychoanalytische Aspekte der Geschlechterbeziehungen im Islam, Diss. Universität Wien, Wien 1995

Rotter, J.: Generalised expectancies for internal versus external control of reinforcement, -in: Psychological Monographs, 80, 1966 (Whole No. 609)

Salgado, J.: Listening to India, listening to ourselves: the place of self in culture, -in: Culture \& Psychology, 2006, 12, pp.101-113

Saß, H. et al.: Diagnostisches und Statistisches Manual Psychischer Störungen - TextrevisionDSM-IV-TR, Göttingen: Hogrefe 2003

Schmidt, B.: Einführung in die Religionsanthropologie, Berlin: Dietrich Reimar 2008

Seymour, S.: Patterns of childrearing in a changing Indian town, Havard University, Harvard 1971 (unpublished doctoral dissertation)

Seymour, S.: Women, family and childcare in India, New York: Cambridge University Press 1999

Singelis, T. M./Brown, W. J.: Culture, self, and collectivist communication: Linking culture to individual behavior, -in: Human Communication Research, 1995, 21, S.354-89

Smith, P. B./Bond, M. H.: Social Psychology across Cultures, Harlow 1998

Smith, P. B./Bond, M. H./Kagitçibaşi, Č.: Understanding social psychology across cultures, London: Sage 2006

Srinivasan, L./Tirupati, S.: Relationship between cognition and work functioning among patients with schizophrenia in an urban area of India, -in: Psychiatric Services, 56, 2005, S.1423-1428

Straub, J./Weidemann, A./Weidemann, D. (Hrsg.): Handbuch interkulturelle Kommunikation und Kompetenz. Grundbegriffe - Theorien - Anwendungsfelder, Stuttgart: Metzler 2007

Strasser, S.: Die Unreinheit ist fruchtbar! Grenzüberschreitung en in einem türkischen Dorf am Schwarzen Meer, Wien: Wiener Frauenverlag 1995

Strasser, S.: Krise oder Kritik? Zur Ambiguität von weiblicher Besessenheit als translokale Strategie, -in: Wohlfart, E./Zaumseil, M. (Hrsg.) Transkulturelle Psychiatrie - Interkulturelle Psychotherapie, New York: Springer 2006 S.299-311 
Welsch, W.: Transkulturalität. Lebensformen nach der Auflösung von Kulturen, -in: Luger, K./Renger, R. (Hrsg.): Dialoge der Kulturen, Wien-St. Johann in Pongau 1994

WHO World Health Organisation: Schizophrenia: An international follow-up study, Wiley-New York 1979

Wittkower, E. D.: Probleme, Aufgaben und Ergebnisse der Transkulturellen Psychiatrie, -in: Ehrhardt, H. E. (Hrsg.): Perspektiven der heutigen Psychiatrie, Frankfurt/M 1972, S.305-312

Wohlfart E./Hodzic, S.,/Özbek, T., 2006, Transkulturelles Denken und transkulturelle Praxis in der Psychiatrie und Psychotherapie, -in: Wohlfart, E./Zaumseil, M. (Hrsg.) Transkulturelle Psychiatrie - Interkulturelle Psychotherapie, New York: Springer S.143-153

Wohlfart, E./Özbek, T.: Die Suche nach offenen Türen. Eine ethnopsychoanalytische Kasuistik über das Phänomen der Besessenheit, -in: Psyche, 60, 2006, S.118-130

Wohlfart, E./Zaumseil, M. (Hrsg.): Transkulturelle Psychiatrie - Interkulturelle Psychotherapie, Heidelberg: Springer Medizin Verlag 2006 


\section{Theater als ein Medium der interkulturellen Kommunikation im Germanistikstudium in Indien}

Manjiri Paranjape

\section{Interkulturelle Kommunikation und indische Germanistik}

Lange bevor der Begriff Interkulturalität in der zweiten Hälfte des 20. Jahrhunderts an Bedeutung gewann, sagte Mahatma Gandhi: „I do not want my house to be walled on all sides and my windows to be stuffed, I want cultures of all lands to be blown about my house as freely as possible. But I refuse to be blown off my feet by any“. .56

Interkulturalität ist ein weitschweifiger Begriff und schließt Kulturvergleiche, Dialoge der Kulturen, interkulturelle Verständigung, Völkerverständnis, Umgang mit dem kulturell Anderen, Selbstbild aus der fremdorientierten Außenperspektive u. a. ein. Interkulturelle Kommunikation ist die Kommunikation über Grenzen. Es ist eine regulative Idee des interkulturellen Dialogs, dass man sich dem Fremden nicht angleichen soll bzw. das Fremde auf das Eigene nicht reduziert werden darf. Man soll vertraut werden aus der Distanz, die das Andere als das Andere und Fremde zugleich sehen lässt. Interkulturelle Kommunikation hilft also, „fremde

${ }^{56}$ Gandhi, M. K. zit. in: thinkexist.com/quotation/i_do_not_want_my_house_to_be_walled_in_on_all $/ 10833$.html 
kulturelle Identität emotional zu erfühlen und zugleich rational zu begreifen und dadurch eigene Identität besser zu verstehen oder erst zu finden“. 57

Die Zeit seit den 80er Jahren des 20. Jahrhunderts kennzeichnet sich einerseits durch Globalisierung, internationale politische Verflechtungen, wirtschaftliche und intellektuelle Mobilität, kulturelle Hybridität und soziokulturelle Grenzverschiebungen. Andererseits wird die Welt bedroht von religiösem Fanatismus, Terrorismus, von der Ausländerfeindlichkeit und von Atomwaffen. Daher ist gerade heute die interkulturelle Kommunikation bzw. der Aufbau einer Kulturmündigkeit durch die Erfahrung und kritische Reflexion der fremden und eigenen Kultur umso wichtiger.

Die Germanistik hat dieser Tatsache Rechnung zu tragen. Seit den 80er Jahren spricht man daher von der interkulturellen Germanistik. Das Verstehen der fremden Kultur, das Nachdenken über eigene Kultur und die Fähigkeit zur interkulturellen Kommunikation werden als Ziele des Germanistikstudiums betrachtet. ${ }^{58}$ Die Germanistik in Indien als eine Auslandsgermanistik ist eine vergleichende Fremdkulturwissenschaft. Als ,German Studies' schließt sie den Sprach- und Literaturunterricht ein. Indien ist ein multikulturelles Land und es gibt eine sehr große Kulturdistanz zwischen Indien und den deutschsprachigen Ländern. Eine Auseinandersetzung mit der Zielkultur ist äußerst notwendig für das Sprach- und Literaturstudium. Man bekommt heutzutage in Indien häufig Gelegenheit, Menschen aus deutschsprachigen Ländern zu begegnen oder in deutschsprachige Länder zu reisen, dort zu studieren und zu arbeiten. Für das Verständnis der Literatur, zur besseren Sozialisation in deutschsprachigen Ländern und um die Sprache als Kommunikationsmittel effektiv verwenden zu können, um Liebe und Sympathie für die fremde Kultur zu erwecken sowie um Vorurteile abzubauen, muss die Fähigkeit zur interkulturellen Kommunikation im Germanistikstudium in Indien gefördert werden.

\section{Theater als Unterrichtsmittel}

Das Wort ,Theater', abgeleitet von dem griechischen Wort theatron (Schauplatz), wird definiert als ,jede schaubare künstlerische Darstellung äußerer oder innerer Vorgänge ... auch ohne Worte (Pantomime), oder als echte Umsetzung des erhaltenen Dichterwortes in schaubare, sinnenfällige Handlung“ ${ }^{59}$ Unter diesem Begriff wird hier das Theaterspielen im Germanistikstudium sowie das Rollenspiel bzw. die Pantomime im DaF-Unterricht verstanden.

\footnotetext{
${ }^{57}$ Hexelschneider, Erhard: Das Fremde und das Eigene als Grundkomponenten von Interkulturalität. Was bedeutet das für den Lehrenden? -in: Wierlacher, Alois (Hrsg.): Perspektiven und Verfabren interk.ultureller Germanistik, München 1987, S.259-280, S.260

58 vgl. Wierlacher, Alios (Hrsg.): Fremdsprache Deutsch, Bd. 1/2, München 1980, S.55, 94, 96

59 Wilpert, Gero von : Sachwörterbuch der Literatur, Stuttgart 1964, S.714
} 

in Indien

Seit den 70er Jahren des 20. Jahrhunderts nahm das Theater als pädagogisches Mittel an Bedeutung zu. ${ }^{60}$ Heute geht man davon aus, dass das Theaterspielen gelernt und geübt werden kann. Außerdem erleichtert die fremde Sprache das Theaterspielen in mancher Hinsicht. Sie verfremdet, „wirkt wie ein Schutzmantel, hinter dem das Agieren leichter fällt". 61

Das Bundesland Maharashtra, wo ich unterrichte, gilt als eine der Hochburgen der Theateraktivitäten in Indien: „Die Menschen Maharaschtras sind geradezu theaterbesessen, sie gehen nicht nur gern ins Theater, sondern wer immer das Zeug dazu hat, spielt selbst Theater"“.62 Diese Motivation, Theater zu spielen, dieses Theaterengagement und die sich daraus entwickelnde Theatererfahrung sind bei vielen Studenten auch heute noch bereits vorhanden und können im Lernprozess verwertet werden. ${ }^{63}$

\section{Theater und Kultur}

Das Theater ist ein wichtiger Bestandteil der Kultur. Das Theater stellt die kulturellen Zeichen, Systeme dar, benutzt und interpretiert sie. Es führt die ,primären' Zeichen der Kultur zur ,bedeutungserzeugenden’ Praxis. „Das Theater wird (so) zu einem Modell der kulturellen Wirklichkeit, an dem der Zuschauer mit ihren Bedeutungen konfrontiert wird“".64

Das Theater ist mehrdimensional, ist gekennzeichnet durch Plurimedialität. Es verfügt über verschiedene Codes: Visuelle Codes (Bühnenbild, Requisiten, Choreographie, Gestik, Mimik, Beleuchtung u.ä.), akustische Codes (Musik, Geräusche), linguistische, para- und extralinguistische Mittel. Roland Barthes sagt, im Theater gibt es sehr komplexe und kompliziert aufeinanderbezogene Zeichensysteme. Das Theater besteht in „einer regelrechten Polyphonie von Informationen“. ${ }^{65}$ Alle diese Codes und Zeichen sind kulturabhängig. Erika Fischer-Lichte meint: „Eine Semiotik des Theaters muss also ... durch eine Semiotik der kulturellen Systeme fundiert werden".66.

\footnotetext{
${ }^{60}$ vgl. Ehlert, Dietmar: Theaterpädagogik, München 1986, S.9

${ }^{61}$ Bredella, Lothar/Legutke, M. (Hrsg.): Schüleraktivierende Methoden im Fremdsprachenunterricht Englisch, Bochum 1985, S.187

${ }^{62}$ Rothermund, Dieter : Fünf Mal Indien, München 1979, S.190

${ }^{63}$ Ich habe in den letzten Jahren an der germanistischen Abteilung der Universität Pune einige Theaterexperimente gemacht: Theateraufführungen, Einsatz des Rollenspiels, der Pantomime und der anderen Theatertechniken im DaF-Unterricht, Bühnenbearbeitungen von Hörspielen und epischen Werken, Kreatives Schreiben für das Theater und Übersetzen für das Theater u.a.

${ }^{64}$ Fischer-Lichte, Erika: Semiotik des Theaters. Eine Einführung, Tübingen 1983, S.197; vgl. auch S.19, 195

${ }^{65}$ Barthes, Roland, zit. nach: Greiner, Nord von: Übersetzung und Literaturwissenschaft, Tübingen 2004, S.138; Barthes, Roland: Literatur und Bedeutung, -in: Literatur oder Geschichte, Frankfurt 1969, S.103; vgl. dazu Pfister, Manfred : Das Drama. Theorie und Analyse, München 51988, S.25, 26

${ }^{66}$ Fischer-Lichte, Erika: Semiotik des Theaters. Eine Einführung, Tübingen 1983, S.29; vgl. auch S.62, 169
} 


\section{Theater als ein Medium der interkulturellen Kommunikation}

Die oben erwähnten Merkmale des Theaters führen zur Förderung der interkulturellen Kommunikation. Als Nächstes möchte ich unterschiedliche Möglichkeiten in Bezug auf den Einsatz des Theaters im Germanistikstudium in Indien darstellen und verdeutlichen, wie dieser Einsatz zur Förderung der interkulturellen Kommunikation beitragen kann. Dabei gehe ich von mir durchgeführten Theaterexperimenten und von meinen Unterrichtserfahrungen aus.

\section{Theaterbesuch}

Ein fremdsprachiges und fremdkulturelles Theaterstück zu sehen, ist eine interkulturelle Erfahrung. Die fremde Kultur wird im Theater konkretisiert. Die äußeren Umstände wie Figuren, Kostüme, Bewegungen, Raum und Zeit werden bei der Bühnenrealisation konkret veranschaulicht. Wegen der lebensnah dargestellten Welt begegnet man im Theaterspiel auch den geistigen Bereichen der Kultur wie fremden Perspektiven, Werten, Einstellungen, Weltanschauungen und Denkweisen. Der Zuschauer erlebt die Handlung sinnlich-gegenwärtig als ,hier' und ,jetzt'. Bei aller Fremdartigkeit erscheint der Raum real durch die Konkretheit des Theaterraumes und der Schauspieler. Im Vergleich zu anderen audiovisuellen Medien wie Film ist das Theater ein unmittelbares, lebendiges Erlebnis.

In Indien werden oft Filme, Musikkonzerte, Bilderausstellungen aus deutschsprachigen Ländern veranstaltet, aber sehr selten bekommt man die Gelegenheit, eine deutschsprachige Theateraufführung zu besuchen. ${ }^{67}$ Einige deutsche Theaterstücke sind auf der Marathi-Bühne aufgeführt worden. Die Aufführung eines übersetzten Textes ermöglicht eine interkulturelle Kommunikation. Auf der MarathiBühne findet man aber kaum nennenswerte Übersetzungen deutschsprachiger Theaterstücke; ${ }^{68}$ zumeist sind es Adaptationen.

\section{Theatertechniken im DaF-Unterricht}

Im DaF-Unterricht kann man Rollenspiele, Pantomime oder Simulation von Situationen einsetzen, um einige fremdkulturelle Elemente vorzuführen und sie mit den Eigenen zu vergleichen.

Theatertechniken dienen dazu, kulturelle Konnotationen der Wörter und Ausdrücke zu erklären, wie etwa ,gemütlich' oder, es zieht'. Man kann beim Spielen der Situationen auch einige abweichende, kulturbedingte nonverbale Elemente beibringen, wie nicken, um ,ja zu sagen oder mit drei Schwurfingern schwören u. ä. Man kann ein Rollenspiel einsetzen, um die soziale Rolle des Gesprächspartners zu verstehen oder in gegebenen Situationen angemessen reagieren zu können: wann

\footnotetext{
${ }^{67}$ z.B. hat Das Gripstheater, Berlin, 2001 Max und Mili und Linie 1 in Pune aufgeführt.

${ }^{68}$ Ein einziges, nennenswertes Beispiel wäre die Aufführung von Nagari Andhera, einer Übersetzung von Andorra von Ratnakar Matkari in den 70er Jahren.
} 

in Indien

sagt man z.B. ,Guten Appetit‘ und wann ,Mahlzeit‘ u. ä. Landeskundliche Informationen kann man auch durch Pantomime oder das Spielen einer Szene kontrastiv vermitteln: wie feiert man z.B. Weihnachten in Indien und in Deutschland, oder wie begrüßt man sich in Deutschland und in Indien. Es ist eine interessante Aufgabe, einige Situationen kulturkontrastiv spielen zu lassen, wie z.B. das Bezahlen im Restaurant. Es lässt sich daran verdeutlichen, dass in Deutschland oft getrennt bezahlt wird; d. h. jeder bezahlt das, was er oder sie bestellt hat.

\section{Theaterspielen}

Im Germanistikstudium kann man mit B.A.-, M.A.- und M.Phil.- Studenten ein Theaterstück oder kurze Szenen aufführen. Man kann kurze epische Texte dramatisieren lassen. Da die Theatersemiotik Kulturzeichen benutzt, bietet das Theaterspielen die Gelegenheit, sich mit der Vielfalt einer fremden Kultur zu konfrontieren und in der Begegnung mit dem, Anderen' sich selbst im Spiegel des Fremden neu zu sehen. Die in einem Theaterstück dargestellte Welt ist oft in einem bestimmten soziokulturellen Raum verwurzelt. Mounin meint, dass Bühnentexte wegen der Inszenierung kontextabhängiger als andere Formen sind. ${ }^{69} \mathrm{Im}$ Theater geht es um eine leibhaftige, in der Gesellschaft verankerte Wirklichkeit, die in einen Lebenszusammenhang gestellt wird. Daher kann man durch das Theaterspielen Sozial- und Verhaltensnormen, fremde Handlungsmuster und Kulturtechniken kennen lernen. Das Selbst-Aufführen verdeutlicht einige landeskundliche und kulturelle Aspekte z.B. die Aufführung eines Stückes, wo es um einen Todesfall geht, erhellt kulturspezifische Bräuche wie Beerdigungszeremonie, Trauerpredigt, Trauermahlzeit u.ä.

Der Raum im Theater ist konkret, ist ein Aktionsraum für die agierenden Figuren und als solcher ist er kulturbedingt. Die Zeit wird im Drama aufgrund der Bühnenrealisation durch die entsprechende Beleuchtung, Musik, Geräusche, Kostüme u.ä. konkretisiert. Alle diese Aspekte sind kultur- und kontextbezogen. So ermöglicht das Theaterspielen interkulturelles Lernen auch bei der Gestaltung des Bühnenbildes, bei der Anfertigung der Kostüme, bei der Konzipierung der Musik und Beleuchtung. Man kann dabei Ähnlichkeiten und Abweichungen von der eigenen Kultur besser kennen lernen.

Die Figuren werden im Theater hauptsächlich durch die indirekte bzw. implizit-figurale Charakterisierungstechnik dargestellt, d.h. ein Charakter wird durch sein Handeln, seine Redeweise, seine Gestik und Mimik dargestellt. Alle diese Aspekte sind kulturabhängig. Beim Spielen einer Rolle lernt man fremdkulturelle Körpersprache, Gestik, Mimik, choreographische Bewegungen. Durch Identifikation mit der Rolle vollzieht der Schauspieler ein von deutscher Kultur geprägtes Denken und Handeln nach. Das führt zum tieferen Verständnis des fremden Vol-

${ }^{69}$ vgl. Greiner (2004), S.135; Mounin, G.: Die Übersetzung. Geschichte, Theorie, Anwendung, München 1967, S.35f. 
kes. Dadurch, dass man die Rolle einer fremden Person spielt, kann man Gefühle, Werte, Einstellungen fremder Menschen nachvollziehen. Das Theaterspielen, die konkrete Darstellung auf der Bühne und die Übernahme einer Rolle können Klischees und Vorurteile abbauen und das Sehen mit fremden Augen ermöglichen, und so zur erhöhten Sensibilisierung beitragen und zur positiven Einstellung zur Zielkultur führen.

Im Theater wird die Fremdsprache in ihren soziokulturellen Kontext eingebettet. Bei der Aufführung lassen sich die kulturbedingten Konnotationen der Ausdrücke erkennen und verdeutlichen. Die Sprache im Theater ist die gesprochene Sprache. Daher kann man Dialekte, Soziolekte, Jargon, idiomatische Wendungen, die kulturspezifisch sind, kennen lernen. Man muss sich auch die Art der Diktion aneignen, die sozial und kulturell bedingt ist. Die gesprochene Sprache ist im Theater verbunden mit paralingualen Elementen wie Tempo, Rhythmus und mit extralingualen Elementen wie z. B. Gestik und Mimik. Pavis nennt das gesprochene Wort im Theater ,Körper-Wort', das „eine sprach- und kulturspezifische Regulierung von gestischem und vokalem Rhythmus und Text " ist. ${ }^{70}$

Ansätze der Pragmalinguistik, Sprechakttheorie sowie Anthropologie verdeutlichen die enge Verbindung zwischen sprachlichen und außersprachlichen Elementen. Nach Z. L. Vitlin übermitteln die para- und extralingualen Elemente bis zu $40 \%$ der Information. ${ }^{71}$ Sie sind integrierende Bestandteile der Kommunikation. Im akademischen Unterricht haben jedoch diese Elemente meistens keinen Platz. Das Theaterspielen ermöglicht das Verständnis und die Anwendung dieser Elemente, die bei der interkulturellen Kommunikation eine wichtige Rolle spielen.

Das Theaterspielen bietet eine Gelegenheit, das Kulturwissen praktisch, konkret und kreativ anzuwenden. Es ist ein „Begreifen durch Handeln“.72 Die interkulturelle Kommunikation kann dabei erprobt werden. Ich möchte gern Goethe zitieren: „Man begreift nur, was man selbst machen kann, und man faßt nur, was man selbst hervorbringen kann“. ${ }^{73}$

\section{Das Schreiben bzw. Bearbeiten für das Theater}

Man kann den Studenten Themen, Situationen, Bilder oder ähnliche Schreibimpulse vorgeben und kurze Spielszenen schreiben lassen, wobei die Studenten sowohl den Haupt- als auch den Nebentext schreiben sollen. Man kann auch epische Kurztexte für eine Bühnenfassung bearbeiten lassen. Beim Schreiben müssen die Studenten an die Aufführung denken. Das Schreiben der Dialoge und der Regieanweisungen ermöglicht interkulturelles Lernen. Nach H. Müller-Michaels können

\footnotetext{
${ }^{70}$ Pavis, P.: Semiotik der Theaterrezeption, Tübingen 1998, S.116f., zit. nach Greiner (2004), S.142

71 vgl. Biechele, Barbara : Verbale und nonverbale kommunikative Äußerungsformen bei der Entwicklung des komplexen Verstehens, -in: Deutsch als Fremdsprache (DDR), 25.Jg., 5/1988, S.274-278

${ }^{72}$ Krumm, Hans-Jürgen: Unterrichtsprojekte - praktisches Lernen im Deutschunterricht, -in: Fremdsprache Deutsch, H.4, April 1991, S.6

${ }^{73}$ Goethe, J. W. v. zit. nach Merkelbach, Valentin (Hrsg.): Kreatives Schreiben, Braunschweig 1993, S.59
} 

in Indien

die Studenten im Schreiben von Stücken ,ihre eigene kulturelle Mündigkeit erweitern". ${ }^{74}$ Die Schreibversuche verdeutlichen einige Missverständnisse, Klischeevorstellungen bzw. Vorurteile - wie ,in Deutschland fährt jeder einen Mercedes'. Man kann dann über das Geschriebene diskutieren, um solche Vorstellungen zu korrigieren oder zu beseitigen.

\section{Übersetzen für das Theater}

Da jede Sprache in dem jeweiligen Kulturraum fest verwurzelt ist, bezeichnet Vermeer Translation als einen transkulturellen Transfer. ${ }^{75}$ Stolze sagt: „Übersetzen ist Eingliedern eines fremdkulturellen Textes in eine Zielkultur". ${ }^{76}$ In der Übersetzung ändert sich also auch das Original. Die Tatsache ist wichtig, „,dass eine Übersetzung als eigenständiger Text auch und gerade in seinen Abweichungsbereichen die dynamische Beziehung zweier unterschiedlicher, in einem Text repräsentierter Kultursysteme widerspiegelt" .77 Die kulturspezifischen Probleme und Grenzen bei der Übersetzung, die Abweichungen vom Original führen zum Bewusstsein des Eigenen und zum Verständnis des Fremden. Das Übersetzen für das Theater führt auf eine besondere Weise zum interkulturellen Lernen. In jedem Kulturraum gibt es unterschiedliche Theaterkonventionen, bühnenspezifische Sensibilität, die die Bühnenrealisationen bzw. den Konkretisierungsprozess und damit die Übersetzung beeinflussen.

Die Übersetzung für das Theater wird als keine reine Textarbeit sondern als eine Regiearbeit, eine dramaturgische Tätigkeit betrachtet. Die Tatsache wird berücksichtigt, dass eine Bühnenübersetzung zugleich eine mediale Umsetzung des Textes im Theater ist. Susan Bassnett behauptet, dass der Übersetzer der Bühnentexte die Aufführung mit einkalkulieren soll. Die Übersetzung für das Theater ist sozusagen eine stille Inszenierung. ${ }^{78}$

Bei der Übersetzung des Haupttextes bzw. der Dialoge soll man nicht nur den geschriebenen Text sondern das gesprochene Spiel übersetzen, wobei die Diktion kulturbedingt ist. Bei der Übersetzung vom Nebentext muss man die kulturellen Aspekte beachten, was das Bühnenbild, Kostüme, Gestik, Mimik, Musik u.ä. anbelangt.

Bei der Herübersetzung muss man das Fremde genau begreifen, während bei der Hinübersetzung entdeckt man das Eigene neu. Zugunsten einer Bühnenrealisation muss der Übersetzer bei der Hinübersetzung kulturspezifische Sachen genau be-

\footnotetext{
${ }^{74}$ Müller-Michaels, Harro: Drama, -in: Praxis Deutsch, 31/Sept.1978, S.13-18, S.17

${ }^{75}$ vgl. Koller, Werner: Einführung in die Übersetzungswissenschaft, Wiebelsheim 2004, S.71

${ }^{76}$ Stolze zit. nach Snell-Hornby, Mary (Hrsg.): Übersetzungswissenschaft. Eine Neworientierung. Zur Integrierung von Theorie und Praxis, Tübingen 1986, S.137

${ }^{77}$ Greiner (2004), S.135-136

${ }^{78}$ vgl. Greiner (2004), S. 136, 142; Bassnett-McGuire, S. : Translating Spatial Poetry: An Examination of Theatre Texts in Performance, -in: Holmes, J. S. etc. (ed): Literature and Translation - New Perspektives in Literary Studies, London 1978, S.171-176
} 
Manjiri Paranjape

schreiben. Dabei merkt man manchmal, wie viel Fremdes gibt es in dem Eigenen. Die Grenzen der interkulturellen Kommunikation werden auch deutlich: z. B. erwecken Musik und Geräusche in dem jeweiligen Kulturraum ganz andere Assoziationen. Bestimmte Ragas in der indischen klassischen Musik sind für bestimmte Tageszeiten geeignet und erwecken bestimmte Gefühle. Diese Assoziationen können in der Übersetzung nicht vermittelt werden.

\section{Übersetzungen auf der Bühne präsentieren}

Neulich habe ich ein Experiment gemacht. Unter meiner Betreuung haben fünf M.Phil.-Studentinnen fünf Texte aus der Marathi Literatur ins Deutsche übersetzt. Wir haben dann die übersetzten Texte auf der Bühne präsentiert. ${ }^{79}$ Die Fremdsprache wird hier zur Mitteilung, zur Darstellung des Eigenen benutzt. Für die deutschsprachigen Zuschauer bedeutet diese Inszenierung eine fremde Welt in der eigenen Sprache. Hier werden die Grenzen der Kulturen überschritten und es wird eine Art Fusion erzielt.

Dazu nur zwei Bemerkungen: die, indische' Körpersprache beeinflusste die fremdkulturelle deutsche Diktion und Intonation. Die Wirkung des übersetzten Textes auf den deutschsprachigen Zuschauer war oft anders als die auf den Muttersprachler, da jener mit seinem soziokulturellen Hintergrund, mit seinem kulturspezifischen Erwartungs- bzw. Assoziationshorizont das Spiel erlebte.

\section{Literatur}

Barthes, Roland: Literatur und Bedeutung, -in: Literatur oder Geschichte, Frankfurt/M 1969

Bassnett-McGuire, S. : Translating Spatial Poetry: An Examination of Theatre Texts in Performance, -in: Holmes, J. S. u.a. (ed): Literature and TranslationNew Perspektives in Literary Studies, London 1978, S.171-176

Biechele, Barbara : Verbale und nonverbale kommunikative Äußerungsformen bei der Entwicklung des komplexen Verstehens, -in: Deutsch als Fremdsprache (DDR), 25. Jg., 5/1988, S.274-278

Bredella, Lothar/Legutke, M. (Hrsg.): Schüleraktivierende Methoden im Fremdsprachenunterricht Englisch, Bochum 1985

Ehlert, Dietmar: Theaterpädagogik, München 1986

Fischer-Lichte, Erika: Semiotik des Theaters. Eine Einführung, Tübingen 1983

\footnotetext{
79 Projekt: Übersetฉte Welten, fünf Texte aus der Marathi-Literatur ins Deutsche übersetzt und auf der Bühne präsentiert. Aufführungen in Pune, Mumbai, Baroda (2006-07)
} 
Gandhi, M. K. zit. in:

thinkexist.com/quotation/i_do_not_want_my_house_to_be_walled_in_on_all /10833.html

Greiner, Nord von: Übersetzung und Literaturwissenschaft, Tübingen 2004

Hexelschneider, Erhard: Das Fremde und das Eigene als Grundkomponenten von Interkulturalität. Was bedeutet das für den Lehrenden? -in: Wierlacher, Alois (Hrsg.): Perspektiven und Verfahren interkultureller Germanistik, München 1987, S.259-280

Koller, Werner: Einführung in die Übersetzungswissenschaft, Wiebelsheim 2004

Krumm, Hans-Jürgen: Unterrichtsprojekte - praktisches Lernen im

Deutschunterricht, -in: Fremdsprache Deutsch, H.4, April 1991

Merkelbach, Valentin (Hrsg.): Kreatives Schreiben, Braunschweig 1993

Mounin, G.: Die Übersetzung. Geschichte, Theorie, Anwendung, München 1967

Müller-Michaels, Harro: Drama, -in: Praxis Deutsch, 31/Sept.1978

Pavis, P.: Semiotik der Theaterrezeption, Tübingen 1998

Pfister, Manfred : Das Drama. Theorie und Analyse, München 51988

Rothermund, Dieter : Fünf Mal Indien, München 1979

Snell-Hornby, Mary (Hrsg.): Übersetzungswissenschaft. Eine Neuorientierung. Zur Integrierung von Theorie und Praxis, Tübingen 1986

Wierlacher, Alois (Hrsg.): Perspektiven und Verfahren interkultureller Germanistik, München 1987

Wierlacher, Alios (Hrsg.): Fremdsprache Deutsch, Bd.1/2, München 1980

Wilpert, Gero von : Sachwörterbuch der Literatur, Stuttgart 1964 



\title{
Can Intercultural Competence be Taught? Forty Years of Mediating Literature between India and Germany: A Reconsideration
}

\author{
Gerhard Stilz.
}

\begin{abstract}
This contribution partly repeats the title of an article I published more than twenty years ago. ${ }^{1}$ Its key question is quite obviously directed at the centre of what we are trying to do in the humanities - and what I have been trying to do since I first visited India in 1968 on a two-year DAAD lectureship. The optimism of my affirmative answer is based on assumptions concerning the translatability, negotiability and processuality of cultures. It has not been exhausted through recent political setbacks in intercultural communication and understanding. Therefore I plan to expound, in theory and by referring to my own practical experience, how literature (and other media, to be sure) can help to run regular ferries and build solid bridges between cultural achievements which were felt to be alien (or even considered to be non existent to each other) only half a lifetime ago. Knowing that the process of integrating contemporary Indian literature into our Western canons of reading and teaching has not been a one-way process, I will conclude with a number of critical ob-
\end{abstract}

\footnotetext{
${ }^{1}$ Stilz, Gerhard: Commonwealth Literature at School ? or: Can Intercultural Competence Be Taught? in: Literature in English: New Territories. Anglistik und Englischunterricht, Bd.33, ed. by Albert-Reiner Glaap, Heidelberg 1987, pp.101-106, referred to in the following running text giving page nos. in round brackets.
} 
servations on how far our present-day globalisation of styles, tastes and ways of living might or should go towards levelling out cultural differences.

\section{I}

My following observations are obviously centred in Europe as much as they are necessarily centred in my own self. However, having first taught at the University of Bombay, some forty years ago, and later in Australia and in the United States of America, I could not but realize that my own cultural background and competence were limited. I had to learn wherever I went. And, quite obviously, there were ways and means to teach me - through vital and immediate sensory experience, through direct communication with people who spoke one of the languages I had access to, and through my reading. I am going to concentrate here on the latter type of lessons. They may be less impressive, certainly less risky as far as our physical wellbeing or existential integrity is concerned, but they can also, for the very same reason, be more explicit, more extreme and more radical in the consequences they can plausibly depict or demonstrate.

In order to illustrate my points, I will start with a proposal which I first offered to secondary school teachers of English more than twenty years ago, before anyone seriously prophesied German reunification or the fall of the Iron Curtain, let alone a global economy. Having been called upon to explain why students and pupils of English should extend their reading of English literature in order to include Anglophone writers from Commonwealth and other English-speaking countries on a world-wide basis, I suggested a number of arguments which turned out to be not altogether fruitless in the development of the subject in Germany. ${ }^{2}$ It may be worthwhile to re-visit some of these passages and to comment upon them [in square brackets, where feasible] from a present-day perspective.

Anticipating globalization and still unexpectant of our present concerns with "clashes of civilizations" and "wars on terrorism", I envisaged a world in which mutual cultural understanding under the auspices of modernization and enlightenment (which I took to be universal desires and practices) was believed to be possible:

"We live in a world of increasing economic integration and, hopefully, of an increasingly peaceful and civilized debate about suitable measures to eliminate poverty, starvation and discrimination. Furthermore, we live in a time of increasing wanderlust - especially of Germans who travel to the remotest corners of the world - and, perhaps even more important, in a period when part of the young intelligentsia and future ruling classes still come from all over the

\footnotetext{
${ }^{2}$ My recommendations towards the inclusion of 'Commonwealth Literature' in the regular teaching of English formulated at the 'Forum' of the Marburg Anglistentag in 1989 (the year of German reunification) was supported by colleagues and later adopted as a structural guideline for restructuring English Departments in both the new and the old German Bundesländer.
} 
world to train and study in Europe (not least in Germany). In such a world it is only to be welcomed if world studies [a term which, today, sounds innocently free from the meanwhile deeply suspect jargon of globalization] do not only dwell on the surface of exotic topography but also cultivate a deep sympathy and a fundamental readiness to understand foreign cultures with every means available. Language first and foremost is one of these means and, whether in international politics, trade or commerce, English is the lingua franca. Yet in addition to this, concrete and palpable knowledge is necessary of those geographical and historical areas that are supposed to be correlated with one another". (101)

Meanwhile, neither the targets of such polycentrically modernizing and globalizing efforts nor the conditions under which they could possibly be reached (i.e. "deep sympathy and fundamental readiness to understand foreign cultures", next to "concrete and palpable knowledge") should altogether be considered as unworthy, old-fashioned or illusory emanations of cultural imperialism, although they have become suspect in all respects.

Having initially stated that intercultural competence undoubtedly mattered in an increasingly smaller but nevertheless pluralist world, I consequently pleaded for the project of teaching "intercultural literature" in English lessons at school - a project which has meanwhile permeated syllabi and teaching materials in most German states (as it has done in many countries abroad). My argument for maintaining and appreciating cultural plurality was obviously informed by some sort of mythical eco-conservatism believing in the creative superiority of diversified cultural resources over the comparative poverty of monocultures. Perhaps my own upbringing in the fruitful and inventive dialect culture of South-West Germany had prompted me with this nonconformist credo which, I still trust, is quite amenable to peaceful and productive developments. Literature, in this context, I claimed (and continue to claim for reasons that have meanwhile been confirmed with alarming clarity) acquires a special instrumental quality in cultural explorations and negotiations:

"[W]e find that literature, as [an] essential and exceedingly sensitive indicator of intellectual culture, public awareness, and personal feeling, helps us discover those attitudes and predispositions in foreign cultures which remain hidden at first glance. This is all the more important once we have realized (and the process of realization among responsible and far-sighted politicians amounts to exactly the same thing) that it is of no sense or lasting advantage to solely ensure our economic access to foreign worlds. Instead it is ultimately worthwhile in every respect to understand, as far as possible, foreign cultures from the inside out - to get involved with them and to preserve them. We should indeed learn to question the arrogant assumption that our eurocentric view of the world [in spite of grave blunders elsewhere, there is still no need to point fingers in other directions] should be universally valid and reliable [...]. The imagination desirable in a future world and the diversification of thinking re- 
quired for every new invention and discovery presuppose a multitude of cultural resources". (102)

Intercultural competence, I held, is not a romantic luxury or a charitable sacrifice but rather a necessity profitable for both parties concerned:

"[D]ialect stimulates the standard language and keeps it alive - and not vice versa; likewise, it can also be expected that some of the one-sided developments and current failures in our [E]urocentric world may be recognized earlier and corrected in time with the aid of unconventional ways of thinking provided by exotic cultures. The English lesson can make a contribution here, by cultivating and fostering a deeper understanding of English-speaking cultures". (102)

I might have added other languages taught at school (like French) and their postcolonial potential. Yet the question of why and how literature should be able to do this and render such excellent public and political services had to be answered, too. Generally speaking, I pointed out the deep correspondence between the public need to understand the world as a cultural potential rather than fact-oriented regional knowledge, and the inventive practice of creative writing which anticipates, deepens and enlarges whatever is known, by imaginative excursions into the realms of what should and might be expected. I can still quote my enthusiasm for this liberating and empowering faculty of literature without blushing:

" $\mathrm{L}] \mathrm{et}$ us assume that literature can be regarded as a linguistic and intellectual field of experimentation in which private and political problems of everyday life are preformulated, are made tangible in everyday language and are intelligibly shaped for the common reader; let us assume that the fictional reality of literature can serve as a scenario in which difficult and complex facts may be reduced to a comprehensible form, where precarious conflicts can be settled without the necessary consequences of sanctions faced in the empirical world, and may therefore be providently discussed in the truest sense: We can then easily recognize the use and place of the literature class in our given context". (102-103)

But I also still subscribe to my warnings against the literary consumers' uncritical empathy:

"The sympathy aroused in the reader with fictitious characters, his [or her] temporary identification with heroes or victims and the role play in which he [or she] becomes involved, tempts him [or her] to an uncontrolled emotional participation in a world of appearances unless he [or she] is equipped with a proper sense of reflection and criticism. Experimental games with reality make flights from reality possible. This, however, does not basically diminish the true value of literary fiction - that of giving an enthralling and substantial insight into foreign situations, foreign ways of thinking and foreign cultures". (103) 
Corroborating my plea for literature as a major instrument of teaching intercultural competence, I then distinguished four levels on which literature (and in particular narrative writing) works towards the purpose claimed:

1. Being based on language, literature makes familiar with and at the same time trains other ways of speaking and comprehending. This goes clearly beyond the language learning process provided in basic programmes of instruction.

"We may indeed regard the foreign language and the characteristics of its phonetics, morphology, syntax and semantics as a new pair of glasses allowing a new mode of vision. However, when discussing the literature of the Commonwealth [and specifically India], it is not sufficient to state that our linguistic lenses will be English. Instead, we are rather often faced with the problem of grasping the regional linguistic variants and registers and correlating them with Standard English. We have to point out the charm and expressive potential of these variants and see them in their historical perspective. The linguistic analysis and coordination of a text taken form the canon of Commonwealth Literature [thinking for instance of Raja Rao's Kanthapura or Salman Rushdie's Midnight's Children which I had set for my students to read] thus provides us with a sample of an intercultural experience. This demands a willingness to understand and creates an ability to perceive on a level which cannot be reached by other school subjects". (103-104)

2. Narrative texts like novels or short stories (but also, to a lesser degree, poems and plays), by installing narrators and speakers representing culture-specific viewpoints and perspectives, make readers familiar with other ways of seeing, commenting and judging. Even if readers are free to approve or disapprove of the ethical, aesthetical or logical positions thus promulgated or suggested, they are still faced with cultural differences which in real life would possibly ask too much of their sense of tolerance and politeness. Potential conflicts can thus be defused before they arise, intercultural conflict management can be trained in the spaces of fiction. While as readers we are free from the constraints of entering immediate risks, I held that

"[t]he personal narrator [...] enlists our sympathy, compassion and understanding, and thus opens up a segment of the foreign world in a human light. With his authorial voice and competence, however, he [or she] can also provide information which may be as graphic and reliable as a compendium of facts. Whereas a mere documentary study can only claim its temporal truth and validity for regional studies on the basis of its given facts, fiction can reach beyond such limitations: It endeavours to portray and communicate that which is characteristic, that which is not physically comprehensible and materially distinct, that which is felt to exist over and above the transient and the ephemeral. In doing so the immaterial gains a projective reality which cannot be produced in a world of facts". (104)

3. Beyond such other ways of seeing provided by fictional narrators, literary texts, by frequently presenting characters in a more lucid and psychologically more transparent manner than advisable or tolerable in real life, can be seen as the most 
explicit instrument to dispassionately learn and become accustomed to other ways of being. This is particularly helpful in preparing ourselves for intercultural encounters. Surely no fictional character will ever step out of a text in flesh and blood, and the temptation to misjudge the real world by our reading experiences has produced an illustrious series of both real and fictional victims, starting with Don Quixote. Nevertheless, it should still be regarded as an invaluable asset that

"[f]ictional narrative permits [...] the private history to unfold before the background of public events. Only the autobiography [...] places a comparable stress on the description of consciousness, the feelings directing the plot, the hidden and suppressed emotional reactions - in short: the psychological (but no less powerfully effective) reality. No empirical method has yet provided us with a more subtle, more impressive, 'truer' picture of man than literary fiction. This is not something we can prove but we daily testify to this by being fascinated and concerned with fictional characters in our habits of reading, listening and viewing. The literary techniques of characterization, the modes of presenting psychological insights, e.g. reporting thought processes, or describing [...] mental state[s] through interior monologue[s], bring worlds within reach which only a literature-based regional studies programme can do". (104)

4. In my 1987 essay, I finally discerned a "fourth factor which makes literature a particularly suitable agent of foreign cultures". Texts, like other human artefacts, explicitly enter or are implicitly correlated with a system of conventional forms and genres. By evoking traditions, they produce experimental correlations within and between cultural systems. Such systems, including both their normative rules and their transformative openings and tolerances, have always been intimately associated with the basic inventories of what has been called 'culture'. Knowing how a literary text works, within its constitutive traditions of generating significance, can therefore be regarded as equivalent to a basic understanding of the signifying practices prevalent and accepted in a certain society. This provides an intercultural entry to study other ways of correlating. For me, this held the guiding principle for a responsible reading activity which may at the same time be called politically relevant and socially worthwhile:

" $[\mathrm{It}]$ implies that we can, for the most part, discover in our critical reading a meaningful and productive interplay with the literary tradition. The author's playing with genres and sub-genres, the variation of the formal tradition, and the conflict with more or less obligatory models betrays - often demonstratively, often unconsciously - his [or her] own cultural outlook and the cultural profile of a group or of a society. Developments towards [or away from] a national identity, efforts of cultural assertion and demonstrations of personal identity can be gauged from the implicit dialogues between individual literary works and the traditions of literary genre and form. This observation has proved to be valid in the development of the English sonnet, of the Scottish border ballad, the American short story, and it is also valid for attempts to invent and impose specific Canadian, West Indian, Nigerian or Australian, In- 
dian or New Zealand variations on traditional literary forms. [...] A literary work [thus] proves to be a sensitive indicator of cultural [...] relations, not only in the contents that it may communicate but also in the formal conflicts that it may embody". (105)

\section{II}

In view of all this, would I still write that article? Would I have to change my opinions? Or rather change my horizons? In which way?

Political issues have undoubtedly changed aspects of what I said in 1987: the most important one for our purposes is not Afghanistan, not Iraq, not Al Kaida nor President Bush's silly politics - but the Rushdie case. When I delivered a paper on Mulk Raj Anand in Pune in 1979, praising Anand's political and humanist commitment in his first novels (Untouchable, Coolie, Two Leaves and a Bud) and explaining his narrative technique as 'close to naturalism', some of my eminent listeners showed me - quite tactfully - their mild disgust. This was a little more than a matter of taste, but not much more. Had I come in 1989 in order to praise the artistic achievement of Rushdie's Satanic Verses, my listeners would probably have been very considerate to hush me down and keep the matter purely academic. Now literature had become - again - a political affair. The issue at stake seems to be: How far can and should literature (protected by the liberal assumption that, as art, it should please and educate the public but be free from public intervention) how far should literature be allowed to offend people who are ready to sacrifice their lives - and that of others - in order to serve their religious missions? There is no easy solution to this problem. As an Indian politician, I would have weighed communal bloodshed against the banning of a novel - as they did. Yet quite obviously, this political test case showed (as others did in its wake) that culturally specific assumptions differ concerning the relative harm of public annoyance versus the banning of a book (or any other medial expression that may claim to be artistic). And this is something that has to be learnt and re-learnt in intercultural communication. After all, it can be forgotten so quickly, as the case of Rushdie blatantly shows. Rushdie himself seems to have ignored that fictionality was not respected everywhere in the world and did not universally enjoy the protected status of an art immune to public sanctions. Meanwhile, we have re-learnt that art may be exceedingly political, even if artists would like to have it otherwise for one reason or the other. I cannot but support and strengthen this lesson today.

Much of my twenty-year-old text, however, has largely stood the test of time. Above all, I still take my conclusions for granted that

1. "literature lessons in foreign language teaching (and certainly not only the English class) can impart a cultural competence above that of our own empirical horizon of experience" and that 
2. "[1]iterary education and textual analysis can provide a more profound, a more direct and, at the same time, a more reflective insight into the individuality of foreign cultures that could be achieved in the fact-oriented lesson". (105)

Yet, meanwhile, a few clarifications may be needed concerning my concept of culture. I still believe, as I did twenty years ago, in the openness of cultures in a triple sense:

- Cultures are processual. They should not be understood as closed systems of norms and rules and but as vital processes and supra-personal organisms strategically supported by groups and their representatives and tactically used and frequently subverted by individuals. Cultures generate meaning through symbolic systems and yet develop incessantly by consensually handling and negotiating competitive re-definitions and re-allocations in time and space.

- Cultures are therefore negotiable. Their negotiability resides, on the one hand, in the basic ambiguity and potential polyvalency of all sign systems and, on the other hand, in the need of many different people (with different life experiences) to use the same system of a limited number of signs for an unlimited, everchanging processual reality. Negotiations of cultures are inevitably part of the daily practice of cultures among their 'subscribers' and their 'subjects'. Cultures are continually being negotiated from 'within', as much as they can be (and usually are) questioned and negotiated from 'without'. Inviting cultural criticism 'from without' does therefore not necessarily jeopardize the stability of a culture, but can, on the contrary, enrich and strengthen the vitality of cultures. Cultural change, if enforced from without, under asymmetrical power relations, may be disastrous to certain cultural practices, but is, in the long run, not likely to 'extinguish' a culture altogether, in all its performative manifestations.

- Cultures can be said to be translatable in a double sense: a) Since language is only one of the many symbolic systems on which cultures rest (think of music, dance, painting, architecture, but also of eating, dressing, meeting friends, and most other quotidian practices that go without speech), descriptions of cultural processes and events (including literary depictions) can be translated into other languages, provided a suitable vocabulary can be found. The issue of cultural property does not seem to be affected by such translations. b) Beyond that, cultures can also be 'translated' in physical terms. This has been one of the major issues of colonialism, from the Greek beginnings to the twenty-first century. The human problem in such transformations (as they might be more appropriately called) is that they are frequently backed by alien force and violence, which deforms balanced relationships in colonial contact zones. Although the many and often perverse shapes of human submission, collaborative opportunism and clever businessmaking tend to make colonial contact zones a rather motley and confusing web of human relations, their historical record, under asymmetrical power relations, is altogether a sad story of powerful suppression and the bitter adaptation of the subaltern. However, there is also historical evidence that, if the newcomers and the established try 
and communicate perceptively and seriously, they can come to terms so that they both profit from the 'other' culture.

\section{III}

After these general statements, we are left with a number of open questions that need to be addressed:

1. Are my tenets - based on the obvious fact that English literatures have proliferated all over the world - at all applicable to the intercultural relationship between India and Germany? Undoubtedly, Indians and Germans do not necessarily have to communicate through English. A remarkable number of Indological departments in German universities have produced, since the nineteenth century, a host of German mediators who could read, write and speak Sanskrit, Pali or more mundane Indian languages, from Urdu and Hindi to Tamil and Malayalam. Vice versa, many eminent Indians, since the nineteenth century, have picked up German, either from German teachers and missionaries working in India or during their travels and studies in Germany. ${ }^{3}$ Considering the linguistic clarity, logical precision and cultural sophistication of all the languages concerned, there is indeed no reason to doubt the practicability and efficiency of direct translations between German and the Indian languages (and vice versa). Having been instrumental myself in a language teaching programme which, in the late 1960s, successfully imparted German to Indians without the help of the earlier colonial language, I take it for granted that English need not necessarily serve as a lingua franca either within India or between India and Germany, although it can certainly do so. The apparent irony that my present article is nevertheless written in English, begs for an explanation. Quite obviously, English has changed its function and its reputation even within the last forty years. The British colonial language so brilliantly spoken by Nehru and so violently attacked by not a few Indian patriots in the early years of Independence, has gradually lost its disrepute as the language of imperial suppression. Through the massive, competitive agency of the United States, but also through the many, increasingly independent English voices from the British Commonwealth, along with their dominant role in international organizations, international trade, including the media of international communication, English has become, for better or for worse, the world language of our day. Germans tend to acknowledge this, in some cases grudgingly, while Indians have accommodated to the idea that English has become an Indian language officially recognized by the Constitution. English, for these reasons, has become a relevant and a useful medium of intercultural competence between India and Germany. However, both partners may be well advised to learn that the hearts of their friends are best approached through their own native languages.

\footnotetext{
${ }^{3}$ Walter Leifer: Indien und die Deutschen: 500 Jabre Begegnung und Partnerschaft, Tübingen 1969, is still an invaluable guide to such bilateral cultural and literary relations.
} 
2. A second major question in re-reading and trying to make use of a twentyyear old paper is whether the theoretical basis of what has been said is still valid. Certainly, theories concerning the basic concepts of culture and the practice of intercultural abilities have meanwhile progressed and proliferated. Although this is not the place to give a detailed report on the host of 'posts' that we have passed (or by-passed) within the last twenty years, some of them need to be briefly addressed here: What is new and how does it affect our claim?

a) Poststructuralism, a movement triggered above all by Jacques Derrida's seminal books Of Grammatology and Writing and Difference (both first published in French in 1967) has, starting from philosophy, increasingly shaken the notion of truth in the humanities and the belief in the reliability of conveying meaning in language and other symbolic systems. Under these auspices, my trust in the reliability of language as a reasonably safe conveyor of meaning and, even more, my trust in linguistic analysis based on the heuristic usefulness of structural principles becomes questionable. How can literature "give a substantial insight into foreign situations, foreign ways of thinking and foreign cultures" (as I maintained in my 1987 article (103) [cf. above]), if all human perception fails in its quest for substance and can necessarily only produce 'difference'? How could I claim the factual efficiency of fictional worlds, if the very idea of a 'fact' becomes doubtful? And ultimately: Can we discover anything at all by literature or do we only discover and rediscover ourselves when reading texts? I usually defend myself in this slightly luxurious predicament with two simplistic observations: For one, there is a bitter consolation in my experience that a factual disease is found to be clearly more serious and persistent than an imagined one. Second, there may be no doubt that language can produce misunderstandings, especially across cultural boundaries. But the very idea that we can distinguish between understandings and misunderstandings and that we can, by sensitive negotiation, turn misunderstandings into understandings, points to a truth different from difference, valid beyond holipsistic selfishness.

b) Postmodernism, starting with Jean François Lyotard's The Postmodern Condition (first published in French 1979) has entered discussions on art, architecture, industrial design and, last but not least, in the wake of David Harvey (1987) and Fredric Jameson (1991), my field of English literature. This movement, occasionally styled into a playful antidote to stern Modernism and obliging enlightenment, is based on poststructuralism in its basically anti-fundamentalist assumption that all truths are relative and that, therefore, all values are, in a way, negotiable matters subject to different perspectives and attitudes. The distinction between 'high' and 'low' culture, under postmodernism, has been disbanded as untenable, as simply reflecting the value system of a powerful elite which puts a higher price on what they wish to reserve as 'high culture'. To a certain extent, it may be claimed that the revaluation of Commonwealth writing and the inclusion of the New Literatures' in western canons of reading profited from the postmodern turn. But my argument in 1987 did not subscribe to the postmodern charter of 'anything goes' 
when I qualified literature as an "essential and exceedingly sensitive indicator of intellectual culture, public awareness and personal feeling”. (102) To fashionable postmodernists, not only my stubborn belief in something "essential" but also my discerning valuation of "intellectual culture" would have betrayed me; and my presumption that literature can help us to "understand, as far as possible, foreign cultures from the inside out" (102) would certainly have confirmed me as an inveterate essentialist. Yet I was nothing of the sort but rather believed - as I still believe - in the viability, productivity and vital necessity of a constructivist hermeneutics. I therefore still repeat and, in the light of our days, renew my verdict on "flights from reality", both philosophical and literary.

c) Postcolonialism, finally, is the last 'post' which must be discussed here. This term was virtually unknown in literary studies when I wrote my article in 1987. Edward Said whose Orientalism (1979) is said to be the seminal entry to postcolonial studies, does not use this historical and political term, which was only effectively introduced into our field, under Salman Rushdie's catchphrase The Empire Writes Back (1989), through the much-debated collaborative effort presented by Bill Ashcroft, Gareth Griffiths and Helen Tiffin. Critical voices questioning the alienating dominance of the postcolonial perseverance of English and the British educational system, like Ngugi wa Thiong'o in Decolonizing the Mind (1986) or sceptical questions concerning the power of dominant discourses like Gayatri Spivak in Can the Subaltern Speak (1988), preceded this effort. From then on, what had been regarded - not always patronizingly but certainly with the generalizing eyes of the avid comparatist - as "Commonwealth Literature", became a much more consciously differentiated field of the "New Literatures in English" - irrespective of the fact that some of the texts were not very new and that the term "Commonwealth" literature, at least implicitly, could be understood to include literature not written in the language of the colonizer.

Indian literature, starting from Sanskrit, had long before been on the agenda of Indological departments in Germany (as elsewhere), and Indian English literature has been entering lists of recommended reading in English Departments since the seventies. My introductory reader Grundlagen zur Literatur in englischer Sprache: Indien [Foundations of Literature in English: India] was compiled in 1979 and was published by Fink (Munich) in 1982.4 The Frankfurt Book Fair, devoting its special section to India in 1986, was still unable to leave a lasting impression on German publishers, bookshops and readers. German unification in 1989/1990 even withdrew some of the earlier interest in overseas developments. While recommending Indian authors to German publishers in 1990 was still a rather frustrating effort, the increased opportunities for overseas travel in the nineties, along with the pressing issues of economic globalization, gave an unprecedented boost to Indian authors who, like Salman Rushdie - and more successfully than his illustrious prede-

${ }^{4}$ Meanwhile, a second, substantially revised and updated edition is being prepared for students and secondary school teachers of English; cf. also Stilz, Gerhard/Dengel-Janic, Ellen (eds.): Postcolonial Literatures in English: Sources and Resources, Vol.1: South Asian Literatures, Trier 2010 
cessors Mulk Raj Anand, Raja Rao or R.K. Narayan - had learned to appeal to a Western audience without giving up their 'Indianness'. Authors like Amitav Ghosh, Rohinton Mistry, Kiran Nagarkar, Arundhati Roy, Vikram Seth, or Shashi Tharoor were thus supported by international publishers and even translated for German readers who were now ready to mentally invest in the 'growing industry' associated with India's liberalized market. Not surprisingly, even translations of older 'classics' such as Raja Rao's Kanthapura (Zurich: Dörlemann, 2003) seemed to be promising now. Twenty years after the first courageous step, the renewed special emphasis on Indian literature during the Frankfurt Book Fair in 2006 met with a more favourable and lasting response.

Indian writing in Germany will, of course, be felt to be an exotic product for many years to come. Under such conditions, Indian authors will be gladly pardoned for retaining some of their exotic charm which is their natural prerogative to produce. Vice versa, German authors will inevitably remain exotic to most Indian readers, even if considerately translated into Indian national languages. Such unavoidable cultural exoticism will be part of the challenge which activates readers to train their intercultural competence. Good authors, as we know and should truly appreciate, do not and should not care more about their audience than about their emerging fictional worlds and characters and, above all, the proper way of rendering these unborn realities in the language they are most familiar with. If authors of world literature can be obliged to produce any intentional exotic charm in their works, it is the charm of novelty to mankind rather than the charm of selling their countries in attractive terms to remote audiences. In other words: There is no need for Indian authors to adapt their plots, styles or characters to Western expectations. Good translators will do whatever is necessary in this respect. Good critics will explain what needs to be explained and good readers will wish to learn - not least through the elements of cultural resistance built into the literary text. Literature can thus become a major road to intercultural competence.

\section{Literature}

Ashcroft, Bill/Gareth Griffiths/Helen Tiffin: The Empire Writes Back, London 1989

Derrida, Jacques (1967): Of Grammatology, transl. by Gayatri Chakravorty Spivak, Baltimore-London 1976

Derrida, Jacques (1967): Writing and Difference, transl. by Alan Bass, London-New York 1978

Harvey, David: The Condition of Postmodernity: An Enquiry into the Origin of Cultural Change, Oxford 1989

Jameson, Fredrick: Postmodernism, or The Cultural Logic of Late Capitalism, Durham, NC 1991 
Leifer, Walter: Indien und die Deutschen: 500 Jahre Begegnung und Partnerschaft, Tübingen 1969

Lyotard, Jean-François: The Postmodern Condition: A Report on Knowledge, Manchester 1984

Ngugi wa Thiong'o: Decolonising the Mind: The Politics of Language in African Literature, London 1986

Said, Edward: Orientalism, London-New York 1978

Spivak, Gayatri Chakravorty: Can the Subaltern Speak?, -in: Nelson, Cary/ Grossberg, Lawrence (eds.): Marxism and the Interpretation of Culture, Chicago 1988, pp.271-313

Stilz, Gerhard: Grundlagen zur Literatur in englischer Sprache: Indien, München 1982

Stilz, Gerhard: Commonwealth Literature at School - or: Can Intercultural Competence Be Taught?, -in: Literature in English: New Territories, Anglistik und Englischunterricht Bd. 33, ed. by Albert-Reiner Glaap, Heidelberg 1987, pp.101-106

Stilz, Gerhard/Dengel-Janic, Ellen (eds.): Postcolonial Literatures in English: Sources and Resources, Vol.1: South Asian Literatures, Trier 2010 



\title{
Hegel in India ${ }^{1}$
}

\author{
Sharad Deshpande
}

The title of this essay stands for a sub-text of a much wider and extremely complex theme expressed by such apparently simple phrase as "India and Europe". 2 The main text, i.e. India and Europe, conceived historically and with its immense complexities narrates how Europeans and Indians have viewed each other in terms of their respective 'Life-worlds'. The main text thus deals with a two way reception of ideas and beliefs in religious, socio-cultural, and philosophical traditions of these two great civilizations. The sub-text, i.e. Hegel and India, will not be intelligible unless one is acquainted with the theme of the main text as developed in the framework of the European view of the Orient and also the specific Indian context which provides a necessary background to the sub-text. It will be useful to take note of some of the main historical facts which have determined Hegel's interests in understanding and developing his attitude towards the Orient in general and towards India, i.e. Indian philosophy and religion in particular. Alternatively, Hegel's alleged influence will be discussed in the specific context of the modern Indian philosophers' encounter with Hegel.

\footnotetext{
${ }^{1}$ Earlier versions of this essay were presented at University of Göttingen and University of Pune. Thanks to Ines Fornell (University of Gottingen) Mangesh Kulkarni and Aniket Jaaware (University of Pune), V. Sanil (I.I.T. Delhi), Kanchana Mahadevan (Mumbai University) and Rajan Gurukkal (M.G.University, Kottayam) for critical comments.

${ }^{2}$ Halbfass, Wilhelm: India and Europe, New York 1988
} 


\section{I}

Hegel's interest in India, as it becomes evident through his writings, is incidental to his life time project of understanding the existing human condition in terms of universal history. It is said that before Hegel, history was in plural; Hegel turned it into a singular history of mankind. This history was abstract and universal. The Hegelian project consisted in discovering the telos and the process of this abstract universal history. His interest in India, or for that matter, his interest in any other non-European civilization, is a part of understanding this universal history. His interest in India is also to be distinguished from that of the German Indologists and the Romantics. ${ }^{3}$ Contrary to the main focus of German Indology, Hegel was not interested in philological reading of Indian texts. He made no efforts to learn Sanskrit or any other Indian language. ${ }^{4}$ In fact, Hegel's writings on India were not received favourably by German Indologists saying that "Hegel was a 'bookman', living in the world of abstractions and speculations, unwilling and unable to adjust his conceptual schemes to the empirical evidence". 5 "Moreover, he was a "prototype of a Westerner', who saw Western thought as the measure of all things". ${ }^{6}$ On the other hand, Hegel did not share the interests of the Romantics in understanding the Orient and particularly India in terms of the alternate ways of religious experience and self-fulfilment. He opposed the Romantics in their efforts to glorify the Orient and particularly India, in terms of the doctrine of the 'origin' and 'early stages of history'. This opposition to the Romantics stems from Hegel's philosophy of history which recognizes the ontology of the 'present' and the irreversible direction of history. Hegel's engagement with India is that of a European philosopher "whose philosophy commits him to not being neutral". ${ }^{7}$ Hegel was not just a passive participant in the European philosophical tradition. He made "a conscious effort to comprehend and fulfil it in his own thought". ${ }^{8}$ Hegel was one sided, but his "one-sidedness is not a simple bias: it is a matter of intense historical and systematic reflection and a challenge to the very idea of objective intercultural understanding". ?

Hegel's acquaintance with India was based on secondary sources, mainly through the translations of some Indian texts by his contemporaries Colebrooke, Schlegel, and Humboldt, along with the translations in English by W. Jones, F. Wilford, and J. Mill. He had read and responded to Colebrooke's essays on "The Philosophy of the Hindus". These essays present two major orthodox Indian philosophical systems, namely, Sāñkhya and Nyāya-Vaiśesika. Hegel not only wel-

\footnotetext{
${ }^{3}$ Halbfass (1988), pp.84-85

4 ibid, p. 85

5 ibid, p. 84

6 ibid

7 ibid

8 ibid

9 ibid, p.84-85
} 
comes these essays "as a new basis for the western understanding of Indian thought" 10 but he also refers to them in his lectures on history of philosophy. He had also read and responded to Humboldt' essays on Bhagavadgitā. He welcomed these essays as setting the required standards for translation. His long review article of Humboldt's essays published in 1827 is, in a sense, "his testament, as far as his understanding of India is concerned". ${ }^{11}$

As per the account given by Halbfass, these are supposed to be the only direct sources of Hegel's acquaintance with Indian philosophy. It is obvious that by themselves they are not sufficient for forming an informed scholarly view on Indian philosophy. What then makes Hegel one of the important figures in the discourse on India and Europe? An answer to this question lies not in Hegel's reviews of and responses to these translations, but in his views on the nature of history and the nature of philosophy itself. Why Hegel becomes important in this discourse is the way he integrates his reading of the Indian texts with his own system of thought. His philosophy of history has determined his understanding of India and of Indian philosophy. A brief reference to his philosophical system is therefore necessary.

In Hegel's philosophy the present and the past are not only combined but integrated in a fundamental manner. The present (i.e. the system) and the past (i.e. history) are 'the two sides of the self manifestations of the Spirit'. "Historical understanding explicates and objectifies what is implicit in and presupposed by the current conditions of our existence". ${ }^{12}$ Hegel's history of philosophy presupposes this general framework of the binding relationship between the past and the present. His history of philosophy is basically a history of European philosophy which has no place for any other non-European philosophies. This is because his "conception of 'Weltgeist' (the world-spirit) and the corresponding unity of the world historical process, leave no room for the assumption of the other, independent, or parallel streams of historical development". ${ }^{13}$ In this scheme, the Orient and India in particular, has no place, because the Orient has essentially a beginning. ${ }^{14}$ The world-spirit moves from the east to the west.

Hegel's views on the historical movement, i.e. of passing of one stage into another and its application to Indian philosophy are particularly relevant in this context. For him, the principle of substantiality or the substanceness, i.e. the unity and the ultimacy of one underlying substance marks the Oriental, and specifically the Indian stage of thought. For Hegel, the religions of India are basically religions of substance, taking God to be the ultimate, pure and abstract being-in-itself, contain-

\footnotetext{
$10 \mathrm{ibid}$, p.86

11 ibid

12 ibid, p. 87

13 ibid, p.88

$14 \mathrm{ibid}$
} 
ing "all finite and particular beings as non-essential modifications, leaving them without any identity and dignity of their own". ${ }^{15}$

Hegel does not make a substantial difference between religion and philosophy as far as India is concerned. For him they are inseparable. But this is a questionable assumption since religion in the Western sense of the term does not accord with Indian understanding of dharma. One can be a Hindu without believing in God, scripture, or ritual. So Hegel's identification of Indian philosophy with Indian religion is ill-founded.

Hegel's observation that Indian philosophy is substance oriented or substance-centric is validated in the metaphysics of some Indian schools of philosophy. But some schools of Indian philosophy like Buddhism and Cārvākas deny the view that reality is substance. So the claim that Indian philosophy is substancecentric is partial. There are of course schools of Indian philosophy notably that of Vedānta which believe in the Reality as pure, undifferentiated, indeterminate substance. It is the one out of which everything arises and into which everything vanishes. In the terminology of the Vedānta philosophy, this substance is known as Brahman. Hegel is familiar with this term and its meaning. However, he criticizes it on the ground of the "lack of dialectical mediation"16. The flow and the progress of history are dialectical and therefore the relationship between the finite and the infinite must be explainable dialectically. But in the conception of the Brahman as the absolute substance, "the absolute and the infinite is not put to work in and for the finite and relative, and the relative and finite does not affect the infinite. Accordingly, there is no historical progress towards the enhancement of man and the world". 17

Despite Hegel's rejection of Indian philosophy, despite his famous Eurocentric view on India and Indian philosophy, Hegel appealed to many Indian philosophers at the beginning of the 20th Century. The point of contact between Hegel and Indian philosophers is the Hegelian notion of the Absolute. The reception of Hegel by the modern Indian philosophers is in terms of the elaboration of the notion of the Absolute (the term Hegel uses) in the so called cross-cultural perspective. Despite originality and creativity of a very high order this reception tends to be ambiguous, ambivalent, and even problematic. In order to get at the details of Hegel's reception in India it is necessary to turn to the other half of this story.

\section{II}

Historically speaking, Hegel's influence in India is visible in the concluding part of the nineteenth century and the early part of the twentieth century colonial India, particularly in the domain of the active politics of the Communist Party of India

\footnotetext{
$15 \mathrm{ibid}, \mathrm{p} .88$

16 ibid, p. 90

17 ibid.
} 
and in the domain of philosophy that flourished in the academic circles in Indian universities and research institutes. But strangely enough, the Indian historians during this period seem to be unconcerned with Hegel's interpretation and understanding of the course of World History and Hegel's views on historiography. This is perhaps due to the fact that the Indian historians during this period were primarily engaged in recovering the actual historical documents that were needed to write the first order historical narratives of the provincial Indian royalties. There are some exceptions to this silence over Hegel's views on history. In Marathi, for instance, Vishwanath Kashinath Rajwade (1864-1926), a noted historian, does take note of Hegel's philosophy of history. In an essay titled "Rāmadāsa"18 Rajwade summarizes Hegel's view that the State is the concrete manifestation of the Spirit and that it is through the State that the Spirit realizes its absolute freedom. Rajwade reads this in terms of Dāsabodha (advise to the disciple) written by Saint Rāmadāsa ${ }^{19}$ and argues that Dassabodha is a metaphysical treatise on philosophy of history since it states that the State as the moral order is the concrete manifestation of the freedom of the spirit. As historian, Rajwade rejects Hegel's Eurocentric stance as biased due to the lack of knowledge of the actual historical processes leading to the emergence of new political order led by Shivāji in $16^{\text {th }}$ Century India as means to realize freedom.

In the domain of politics, Hegel was certainly not unfamiliar to the Marxist intellectuals and the party workers and also to the socialists. However, the Marxist and the socialist engagement with Hegel during this period was to a great extent secondary, if not minimal, and mainly through Stalin's materialist reading of Marx's reformulation of Hegel's dialectical method in interpreting Indian history and the assessment of her social and economic conditions at that point of time. For the Marxists, Hegel's dialectics as a methodological tool that explains the historical process was more important than his metaphysics of the Absolute. In fact, the Marxists condemned Hegel's metaphysics of the Absolute or his notion of Geist. Hegel was considered as not necessary and to some extent even dangerous. D. K. Bedekar's book on Hegel published much later in 1966, is perhaps the most notable exception to the attitude of Indian Marxists to Hegel. ${ }^{20}$ But given his sensitivity to the acute problems of translation, and his insistence on understanding concepts like Dialectics, Spirit, Geist, and State, in the overall European context, it becomes clear that Bedekar's engagement with Hegel is more academic than that of a party worker. Outside the Marxist and socialist circles, it is interesting to note that a national leader like Bipin Chandra Pal (1858-1932) one of the three triumvirate of Indian National Congress, the famous "Lal, Bal, and Pal," is mentioned as 'a great

\footnotetext{
18 Rajwade, V.K.: Rāmadāsa, -in: Joshi, Lakshmanshastri (ed): Rajwade Lekhasañgraha, New Delhi 1958, pp. $257-260$

${ }^{19}$ Saint Rāmadāsa (1608-1682), believed to be the spiritual Guru of Shivāji

${ }^{20}$ Bedekar, D. K.: Hegel: Jìvan äni tatvajnãn, Pune 1966
} 
Hegelian'. ${ }^{21}$ However, it is a matter of speculation whether, and to what extent, Hegel's influence on the leaders like Bipin Chandra Pal was in any way reflected in their engagement in national politics during the colonial era. This can also be said about leaders of national importance like Justice M.G. Ranade, Lokmanya Bal Gangadhar Tilak, Gopal Krishna Gokhale, and others. Hegel's influence on the English educated intellectuals of the early twentieth century India is a largely neglected area as compared to his influence on modern Indian philosophers. ${ }^{22}$

On this background, the modern Indian philosophers' encounter with Hegel during the early part of the twentieth century colonial India turns out to be a significant but an equally obscure phenomenon. In order to get at some of these obscurities of this phenomenon, the first thing to be noted is that Hegel was not received in isolation, as a philosopher not belonging to this or that particular tradition. Like other western philosophers, Hegel was introduced as part of the history of Western philosophy from the ancient Greeks to the 'modern' western philosophers of the 18th century. The modern Indian philosophers have responded, implicitly or explicitly, to this 'historical' Hegel. This fact has contributed in determining the nature of Hegelian scholarship in India which has its own colonial context of presenting the indigenous philosophical world-views to the West. What was needed for this presentation was a world-view which would be rooted in the Western philosophical tradition and whose vocabulary would not only be known but would also be in practice in the West. This was a requirement that arose out of the overall colonial context in which Indian thought could be presented to the West. This wider context, coupled with the reception of Hegel in the framework of the history of western philosophy, also explains, why the Hegelian doctrine of the Absolute, or what is popularly known as the Hegelian Absolute Idealism has received critical attention from the modern Indian philosophers. Also to be emphasized is the fact that the Hegelian influence on modern Indian philosophers and the response by the Indian philosophers to Hegel are in various degrees. Hiralal Haldar, Professor of Philosophy at Calcutta University is perhaps the only modern Indian philosopher who explicitly proclaims that "the study and interpretation of Hegel and the philosophical movement which has arisen from his influence has been the chief occupation" 23 of his life. Likewise, S. K. Maitra mentions Hegel as his "first philosophical guru". ${ }^{24}$ At the same time, many others, including Haldar, Maitra, and Brajendra Nath Seal, are also frank in admitting the fact of their overcoming the Hegelian influence in the course of their philosophical career. The overcoming of Hegelian influence in the case of these and other modern Indian

\footnotetext{
${ }^{21}$ Maitra, S. K.: Outlines of an Emergent Theory of Values, -in: Radhakrishnan, S./Muirhead, J. H. (eds): Contemporary Indian Philosophy, London 1952, p.380

22 Deshpande, Sharad (ed. with Introduction): Philosophy of G.R. Malkani, New Delhi 1989, p.xvi

${ }^{23}$ Haldar, Hiralal: Neo-Hegelianism, London 1927, p.vi

${ }^{24}$ Maitra (1952), p.380
} 
philosophers is prompted by many philosophical considerations ${ }^{25}$ and at any rate should not be interpreted negatively.

In continuation with the observation made above, viz. that Hegel was studied as part of the history of western philosophy, it is to be noted that Hegel was always read, and interpreted, in tandem with another influential German philosopher Immanuel Kant. In fact, many modern Indian philosophers find in Hegel's Absolute Idealism, what they call the 'culmination' of Kant's Subjective Idealism. This reading is expressed by modern Indian philosophers in various ways and in various degrees. For P. T. Raju, and for many others, Hegel is appealing because through his dialectics he could overcome the opposition between the self and the world by interconnecting the categories (of understanding) 'left unconnected' by Kant. ${ }^{26} \mathrm{~S}$. K. Maitra even goes on to say that he "looked upon Kant an incomplete Hegel and Hegel as the completed Kant". ${ }^{27}$ Hegel's Absolute Idealism and in particular his doctrine of the Absolute is a key to determine Hegel's influence on modern Indian philosophers during the period under consideration. In fact, one finds that the term Absolute has become almost a catchword, a key concept in the writings of modern Indian philosophers. It would not be an exaggeration to say that the most singular question that has occupied modern Indian philosophers in the early part of the twentieth century is 'What is the nature of the Absolute?' and one finds that almost every modern Indian philosopher is proposing his own answer to it and in doing so clarifying his own philosophical position.

What about Hegel's philosophy of history and based on it his understanding of Indian philosophy and religion? This is an important issue in Indological discourse. But did it in any way concern modern Indian philosophers? Brajendra Nath Seal (1864-1938), who has had the reputation of being "one of the greatest Hegelians in India" 28 is perhaps the only modern Indian philosopher who was initially said to be inspired by the Hegelian philosophy of the linearity of history from East to West. But later he rejects it as being too narrow and parochial and in effect precluding the possibility of an equitable cultural dialogue. ${ }^{29}$ Brajendra Nath Seal in repudiating Hegel's Eurocentricism has participated, perhaps unknowingly, in the global debate on Hegel's philosophy of history. But, barring his exception, most of the modern Indian philosophers under reference do not seem to be primarily interested in reacting to Hegel's Eurocentric approach to Indian civilization, nor to his "specific arguments concerning Indian philosophy and religion". 30 As noted above, they have restricted themselves only to Hegel's metaphysics of the Absolute. The

\footnotetext{
25 see below

26 Raju, P. T.: The Inward Absolute and the Activism of the Finite Self, -in Radhakrishnan, S./Muirhead, J. H. (eds): Contemporary Indian Philosophy, London 1952, p.514

27 Maitra (1952), p.380

28 Maitra (1952), p.382

${ }^{29}$ Seal, Brajendra Nath: Comparative Studies in Vaishnavism and Christianity, Calcutta 1899

30 Halbfass (1988), p.99
} 
exclusive reference to the notion of the Absolute is to be interpreted both hermeneutically and historically.

We have been talking about modern Indian philosophers and the reception of Hegel's philosophy. However, the phrase 'modern Indian philosophers' needs a clarification. A modern Indian philosopher is one who, in addition to his acquaintance with the traditional systems of classical Indian philosophy, is also exposed to the major western philosophers belonging to the Greek and the European traditions. This stipulation is made to apply historically to professional Indian philosophers from 1850 to 1950 . During this period, philosophy as an academic discipline of study at the graduate and at some places at the post graduate level was established in Indian universities and colleges. In addition to, but slowly replacing the traditional class of teachers who were titled as Āchārya, Pandit, and Śāstri, a new class of college and university teachers called lecturers and professors had begun to emerge. The concerns of the two classes were entirely different. The traditional Pandits and Śāstries were not interested in presenting the Indian philosophical thought to the west; but this was a historical requirement for the English educated professional philosophers. They were required to write in English and present Indian philosophy to the western readers. Some of the best representative anthologies of the modern Indian philosophers' writings are Contemporary Indian Philosophy, ${ }^{31}$ K. C. Bhattacharyya Commemoration Volume, ${ }^{32}$ and Radhakrishnan: Comparative Studies in Philosophy Presented in Honour of His Sixtieth Birthday. ${ }^{33}$ A large number of research papers were published in The Philosophical Quarterly, ${ }^{34}$ the only philosophical journal that used to be published from India since 1925. By our stipulation, all those who have contributed to these are modern Indian philosophers. They were exposed to the writings of Socrates, Plato, Aristotle, and also to the rationalists (Descartes, Spinoza, Leibniz, Kant, and Hegel), and the empiricists (Locke, Berkeley, and Hume). However, this exposure was largely through the secondary sources in translations, commentaries and text-book expositions in English. P. T. Raju, S. K. Maitra and many other contributors to the Radhakrishnan volume acknowledge their exposure to western philosophy through the commentaries and expositions by English writers like J. H. Sterling, T. H. Green, John Caird, Edward Caird, F. H. Bradley, R. B. Halden, G. S. Morris, and others. Exposure to Hegel's philosophy was mainly through the writings of these philosophers. Baillie's translation of Hegel's Phenomenology of Mind was also available as Haldar reports. To what extent this has determined the modern Indian philosophers' reception of the original European thought (and of Hegel in particular) is an important issue not because of

\footnotetext{
${ }^{31}$ Radhakrishnan, S./Muirhead, J. H. (ed): Contemporary Indian Philosophy, London 1936 \& 1952

32 Maitra, S. K./Malkani, G. R./ Murti T. R. V. (eds): K. C. Bhattacharyya Memorial Volume, Amalner 1958

33 Inge, W. R./Jacks, L. P./Hiriyanna, M./Burtt, E. A./Raju, P.T. (eds): Radhakrishnan: Comparative Studies in Philosophy Presented in Honour of His Sixtieth Birthday, London 1951

34 Pbilosophical Quarterly, ed. by G. R. Malkani, Amalner. The first issue of this journal appeared in April 1925.
} 
the problems of translation per se but because of the translator's or the commentator's own reading of the original texts. This is crucial because appropriation of Hegel in the form of Neo-Hegelianism in England is by itself a complex phenomenon having its own history. ${ }^{35}$ Way back in 1927, Hiralal Haldar, who too is described as a Hegelian, gave a comprehensive and a fairly analytical account of Neo-Hegelianism (which he describes as a study and not a mere history). In order to make a correct assessment of Hegel's influence in India, particularly in the context of Neo-Hegelianism, it is necessary to have a proper understanding of Hegel's philosophical theory as accepted in 19th century England.

During the early part of the 19th century, Hegel was paramount in English philosophy. The reasons for this are historical. The Victorian Age was facing a great challenge of reconciliation of the two opposite world-views, the one generated by the new science and the other by Christianity. The reconciliation of these world-views had to be 'scientifically tenable' and 'religiously satisfying'. Traditional British philosophy was engaged in the epistemological problem of finding the source of knowledge either in terms of sense-experience or in terms of intuition leading to empiricism and intuitionism. What was needed was a comprehensive metaphysics of reconciliation between science and religion that will enable one 'to grasp the true nature of the universe we live in'. It was on this background that James Hutchison Sterling described by Haldar as 'the profoundest student of philosophy' found Hegel far more rewarding than any other philosopher for asserting that the mind and matter are only phenomenal appearances of the same substance, that it is the mind which synthesizes the data of experience supplied by the outside world and the categories of understanding. The Kantian scholarship all over the world is engaged in explicating the nature of this synthesis. The Hegelian intervention at that juncture of time is in terms of the dialectical moment of the synthesizing activity itself, transformed the so-called opposite principles into a synthesis of a higher order. Subjective Idealism was thus sublated into Absolute Idealism. This is how J. H. Sterling represents Hegel to the philosophical world of England. Along with other Indian philosophers cited above, Haldar too quotes from a neoHegelian Sterling: "The critical philosophy thus, in short, so Sterling thinks, finds its culmination in the philosophy of Hegel". ${ }^{36}$ It is important to note that the British idealists had appropriated Hegel within the framework of the Idealistic doctrine and not completely. For our purpose, the immediate point of concern is that Hegel was introduced to the modern Indian philosophers by the British champions of Neo-Hegelianism like Sterling, T. H. Green, Bernard Bosanquet, and F. H. Bradley.

It is true that modern Indian philosophers have responded to Hegel as part of the history of western philosophy and as introduced by the Neo-Hegelians in England. It is also true that this fact has contributed in determining the nature of the

\footnotetext{
${ }^{35}$ Haldar, Hiralal: Neo-Hegelianism, London 1927

${ }^{36}$ Haldar (1927), p.10
} 
Hegelian scholarship in India. Notwithstanding the Neo-Hegelian impact, these responses stemmed from a particular conception of philosophy held by most of the modern Indian philosophers, which in turn was a restatement of the classical Indian view that philosophy is a science of self-realization and through it a path to liberation from suffering. It is said that for Hegel philosophy is the science of the Absolute, which the modern Indian philosophers read and interpreted in terms of Śankarācārya's doctrine of Brahma-Vidyā (the science of the ultimate reality, the Absolute). The comparison between Hegel, (and also Kant, Spinoza, and Bradley) and Śankarācārya (also Rāmānūja but less frequently,) representing allegedly the same or similar philosophical theory about the ultimate nature of Reality, termed by Hegel as the Absolute and termed in the Vedantic tradition as Brahman, thus seems to provide a common focus to assess these various responses. A detailed study of these responses is yet to be undertaken. However, the issues which the modern Indian philosophers found more urgent and familiar can be mentioned in brief.

As noted earlier, the modern Indian philosophers have focused on the central issue of the nature of Hegel's Absolute from the perspective of Vedānta This discourse involved discussing such issues as the relation between the one single Absolute reality and the many which are finite. In Vedanta, this is a problem of the relationship between the Brahman (the absolute reality) and Jagat (the phenomenal world). Within this framework, the relationship between the Absolute consciousness (i.e. Brahman) and the individual consciousness (i.e. jiva) becomes pertinent. Another problem which the Vedāntic philosophers discuss is the relationship between truth and error. How is erroneous perception negated and the truth is arrived at is the central question in Vedāntic epistemology. What I wish to point out is that the Indian reception of Hegel, though it was based on secondary sources and occurred within the framework of British Neo-Hegelianism, eventually got entangled in the issues, controversies, and the idiom of the Vedāntic discourse. This was a typical adaptation of Hegel's concept of the Absolute taken in isolation from his overall perspective on the flow of history.

\section{III}

The broad features of the Indian response to Hegel's Absolute Idealism need to be viewed in more general terms. An inquiry into the nature of this response and the purpose it served generates intertwined historical and critical questions which could be located in the larger framework of comparative philosophy. In 1940, K. C. Bhattacharyya, acknowledged as the most articulate and original modern Indian philosopher, raised a critical question about comparison in the realm of 'ideas and ideals'. His critique of the blind and superficial assimilation of alien ideas and ideals into one's own mould or even a superficial comparison amongst concepts belong- 
ing to two different cultures is very forcefully expressed by using a contemporary political term swarāj (i.e. self-rule) in the realm of ideas. ${ }^{37}$ In his "India and the comparative method" 38 Halbfass traces the historical emergence of the comparative method and its application to India and Indian tradition. He looks at the comparative method in the framework of the mutual understanding of India and Europe and in terms of such issues as 'How did Indians use comparative method in understanding the west and to interpret their own tradition?', 'How do the European and Indian usages of comparison relate to one another?', 'How does mutual comparison, and in general, the openness to foreign traditions, relate to the European tradition on the one hand and to the traditional Indian thought on the other?' At a deeper level issues in comparison presuppose what J. L. Mehta calls recognition of "the dimension of historicity intrinsic to philosophical understanding". 39 He finds a lack of recognition of this dimension even in the writings of K. C. Bhattacharyya. He attributes this lack, in part, to the "ahistorical climate of philosophical thought at the time in the English speaking world in general and of its reception of Hegel in particular and in part to the ahistorical bias of the Indian tradition itself". ${ }^{40}$ A comprehensive survey of the writings of the modern Indian philosophers, which is yet to be attempted, will answer historical questions about various frameworks in which comparisons are made; whereas, a meta-order debate is required to answer critical questions about the assimilation of western ideas and ideals into the Indian scheme of concepts.

The Indian response to Hegel in particular, and to the Western philosophical tradition in general, stems from a particular mind-set. The mind-set of the modern Indian philosophers is characterized by Halbfass and many others as 'apologetic'. It is more a "device for defending the dignity of the Indian tradition against the challenges of Western thought and its claims of superiority and domination". ${ }^{41}$ The role of this motivation in the rigid form of nationalism is conspicuous. The Indian tradition is measured against and reinterpreted in terms of western concepts and teachings, and such comparisons, synopses, or reinterpretation often serve the purpose of proclaiming the superiority, or at least equality of the Indian tradition. This was an important dimension of the intellectual reception of the West in India at the beginning of the 20th century.

\footnotetext{
${ }^{37}$ Bhattacharyya, K. C.: Swaraj in Ideas, (reprint), -in: Indian Philosophical Quarterly, Vol.XI, No.4, Pune 1984

${ }^{38}$ Halbfass, W: India and comparative method, -in: Pbilosophy East and West, Vol.35, No.1, Jan.1985, pp.3-15

39 Mehta, J. L.: The Problem of Philosophical Re-conception in the Thought of K. C. Bhattacharyya, -in: Philosophy East and West, Vol.24, No.1, Jan.1974, p.59-70

40 ibid.

${ }^{41}$ Halbfass (1988), p.424
} 


\section{Literature}

Bedekar, D. K.: Hegel: jūvan àni tatvajñän, Pune 1966

Bhattacharyya, K. C.: Swaraj in Ideas, -in: Indian Philosophical Quarterly, Vol.XI, No.4, Pune 1984 (reprint)

Deshpande, Sharad: (ed. with Introduction): Philosophy of G.R. Malkani, New Delhi 1989

Halbfass, Wilhelm: India and Europe, Delhi 1990 (11988)

Haldar, Hiralal: Neo-Hegelianism, London 1927

Joshi Lakshmanshastri (ed) Rajwade Lekhasamgraha, New Delhi 1958

Maitra, S. K.: Outlines of an Emergent Theory of Values, -in: Radhakrishnan, S./Muirhead J. H. (Ed.): Contemporary Indian Pbilosophy, London 1952

Seal, Brajendra Nath: Comparative Studies in Vaishnavism and Christianity, Calcutta 1899

Radhakrishnan, S./Muirhead, J. H. (ed): Contemporary Indian Pbilosophy, London $1936 \& 1952$

Maitra, S. K./Malkani, G. R./ Murti T. R. V. (eds): K. C. Bhattacharyya Memorial Volume, Amalner (India) 1958

Inge, W. R./Jacks, L. P./Hiriyanna, M./Burtt, E. A./Raju, P. T. (eds):

Radhakrishnan: Comparative Studies in Pbilosophy Presented in Honour of His Sixtieth Birthday, London 1951

Raju, P. T.: The Inward Absolute and the Activism of the Finite Self, -in: Radhakrishnan, S./Muirhead, J. H. (eds): Contemporary Indian Philosophy, London 1952 


\title{
Touristische Begegnungen aus der Perspektive einer Psychologie interkulturellen Handelns
}

\author{
Arne Weidemann
}

\section{Einleitung}

Tourismus ist - als Errungenschaft der Moderne - aus dem Leben der meisten Menschen in den industrialisierten Ländern nicht mehr wegzudenken, und auch in den sich entwickelnden Regionen der Erde verfügen zunehmend größere Teile der Bevölkerung über ausreichende Ressourcen und Möglichkeiten, Freizeit und Urlaub touristisch zu nutzen. Entsprechend bildet die Tourismusindustrie mittlerweile als einer der größten Wirtschaftszweige ein weltumspannendes und globalisiertes Netz aus Dienstleistern und Dienstleistungen, Kunden und Bedürfnissen. Nicht nur einzelne Dienstleister, Ortschaften und Regionen sind heute vom Tourismus wirtschaftlich abhängig, sondern ganze Staaten beziehen - wie etwa Nepal oder Thailand - den größten Anteil ihrer Einkünfte aus dem Tourismus. ${ }^{1}$

Tourismus ist jedoch nicht nur als Wirtschaftszweig bedeutsam, sondern zählt neben dem Leben in multikulturellen Gesellschaften und globalem Handel zu den relevantesten Kontexten, in denen Menschen Kontakt mit Personen aus anderen Kulturen haben. ${ }^{2}$ Tourismus kann daher zu Recht als einer der ,wichtigsten ,Motor[en]' weltumspannender interkultureller Kommunikation“"3 bezeichnet werden.

1 vgl. Vorlaufer, Karl: Tourismus in Entwicklungsländern. Möglichkeiten und Grenzen einer nachbaltigen Entwicklung durch Fremdenverkebr, Darmstadt 1996

2 Luger, Kurt: Kulturen im Veränderungsstreß. Kulturtheoretische Überlegungen zur Tourismusdebatte, -in: Luger, Kurt/Inmann, Karin (Hrsg.): Verreiste Berge. Kultur und Tourismus im Hochgebirge, 
Interessiert man sich für interkulturelle Verständigung, erscheint die Beschäftigung mit Tourismus nicht nur aus Gründen der Vollständigkeit geboten. Vielmehr sind mit dem Handlungsfeld ,Tourismus' spezifische Phänomene verknüpft, deren Betrachtung das Spektrum der bisher stark auf Wirtschaftskontakte ausgerichteten interkulturellen Forschung in sinnvoller Weise erweitern kann. So erscheint bedeutsam, dass im touristischen Kontext - zumindest auf Seiten der Reisenden die Begegnung mit Fremden und Fremdem häufig mit „positiven Erwartungen“ und „Neugier"“4 verknüpft ist. Zudem sind Reisen in spezifischer Weise mit gedanklichen Antizipationen, „Sehnsüchten“ und „Imaginationen“ sowie „körperlichem Erleben“ verknüpft. ${ }^{5}$ Die Beschäftigung mit Tourismus rückt so etwa andere Formen, Motive, Bedingungen und Moderatoren interkulturellen Kontakts in den Blick als die Analyse interkultureller Wirtschaftsbeziehungen oder die von Konflikten in multikulturellen Gesellschaften. Schließlich legt die Beschäftigung mit Tourismus in besonderer Weise die große Komplexität konkreter interkultureller Handlungszusammenhänge offen, treffen doch im Tourismus globalisierte, glokale und lokale Praxis in je unterschiedlicher Art und Weise aufeinander, bringen touristische Kontexte Menschen ganz unterschiedlicher Länder, Schichten, Motive, Ziele und Tätigkeiten am selben Ort in Kontakt. ${ }^{6}$ Vor diesem Hintergrund sollen deshalb interkulturelle Begegnungen von Einheimischen und Touristen (HostGuest-Interaktionen) aus handlungstheoretischer Perspektive (insbesondere der Symbolic Action Theory von Ernst E. Boesch) ${ }^{7}$ erörtert und an einem empirischen Beispiel dargestellt werden.

Ich beziehe mich dabei auf meine Forschungen in Leh/Ladakh (Nordindien), das als religiöses und Handelszentrum eine lange Tradition regen wirtschaftlichen und kulturellen Austauschs kennt und sich seit der (Wieder-)Öffnung für ausländische Besucher im Jahr 1974 zu einem wichtigen Reiseziel für Touristen aus dem In- und Ausland entwickelt hat.

Neben der spektakulären Hochgebirgslandschaft und den religiösen und kulturellen Sehenswürdigkeiten spielen als Reisemotive insbesondere auch Sehnsüchte und Imaginationen (westlicher) Reisender eine große Rolle in der Darstellung und Wahrnehmung Ladakhs und seiner Bewohner. ${ }^{8}$

Innsbruck 1995, S.19-42; Lüsebrink, Hans-Jürgen: Interkulturelle Kommunikation, Stuttgart 2005; Mörth, Ingo: Fremdheit, wohldosiert. Tourismus als Kultur der kontrollierten Begegnung mit dem Fremden, Trans, 15, 2004, (http://www.inst.at/trans/15Nr/09_1/moerth15.htm); Ward, Colleen/Bochner, Stephen/Furnham, Adrian: The Psychology of Culture Shock, London 2001

${ }^{3}$ Lüsebrink (2005), S.3

${ }^{4}$ Stagl, Justin: Eine Geschicbte der Nengier - die Kunst des Reisens 1550 - 1800, Wien [u.a.] 2002

${ }^{5}$ vgl. Hennig, Christoph: Reiselust. Touristen, Tourismus und Urlaubskultur, Frankfurt/M 1999

6 vgl. Weidemann, Arne: Tourismus, -in: Straub, Jürgen/Weidemann, Arne/Weidemann, Doris (Hrsg.): Handbuch Interkulturelle Kommunikation und Kompetenz, Stuttgart-Weimar 2007, S.613-627

${ }^{7}$ Boesch, Ernst E.: Symbolic action theory and cultural psychology, Berlin-New York 1991

8 vgl. Gillespie, Alex (2004a): Returning Surplus: Constructing the architecture of intersubjectivity, Cambridge: University of Cambridge, (Dissertation) 2004; Gillespie, Alex (2006a). The future and the other: Striving tourists in Ladakh, 4th International Conference on the Dialogical Self, 2006 
Im Folgenden versuche ich aufzuzeigen, in welcher Weise diese Erwartungen und stereotypen Vorstellungen Handlungswirksamkeit in touristischen Interaktionen vor Ort erlangen und welche Schlüsse sich daraus für die Erforschung interkultureller Kommunikation und Kompetenz ziehen lassen.

\section{Kultur- und Handlungstheoretische Grundlagen}

Die Untersuchung interkultureller Kommunikationsprozesse oder interkulturellen Lernens kann auf Basis unterschiedlicher disziplinärer, theoretischer, methodologischer und methodischer Vorannahmen und Überlegungen erfolgen. In meinen folgenden Ausführungen beziehe ich mich auf kulturpsychologische und handlungstheoretische Prämissen insbesondere der Saarbrücker Schule um Ernst Eduard Boesch und auch Lutz Eckensberger sowie die Erlanger Schule um Hans Werbik und insbesondere Jürgen Straub.

Meinen Überlegungen zugrunde liegt zum einen ein relationaler und dynamischer Kulturbegriff, zum anderen stütze ich mich methodologisch und methodisch auf Jürgen Straubs und Shingo Shimadas Konzept einer Relationalen Hermeneutik, ${ }^{9}$ den Grounded Theory-Ansatz nach Glaser und Strauss ${ }^{10}$ und Strauss und Corbin, ${ }^{11}$ sowie auf insbesondere auch ethnografische Verfahren in Kombination mit diskurs- und artefaktanalytischen Methoden. Mit Doris Weidemann und Jürgen Straub ${ }^{12}$ definiere ich Kultur wie folgt:

„Eine Kultur ist die Gesamtheit von Diskursen, Praktiken und Handlungsobjektivationen, denen ein kollektiv verbindliches, historisch jedoch veränderliches, aus Zielen, Regeln, Geschichten und Symbolen bestehendes Sinn- und Bedeutungssystem zugrunde liegt, das sich durch eine gewisse Kohärenz (Stimmigkeit) und Kontinuität (Dauer) auszeichnet. Dieses Sinn- und Bedeutungssystem ermöglicht Menschen orientiertes Handeln und Verstehen. Es ist die Grundlage all dessen, was die Angehörigen einer Kultur erfahren und erwarten (können). Kultur ist in diesem Sinne der Rahmen allen Handelns (Den-

\footnotetext{
9 Straub, Jürgen/Shimada, Shingo: Relationale Hermeneutik im Kontext interkulturellen Verstehens. Probleme universalistischer Begriffsbildung in den Sozial- und Kulturwissenschaften erörtert am Beispiel ,Religion', -in: DZPbil, 47, 3, Berlin 1999, S.1-29; Straub, Jürgen: Understanding Cultural Differences: Relational Hermeneutics and Comparative Analysis in Cultural Psychology, -in: Straub, Jürgen/Weidemann, Doris/Kölbl, Carlos/Zielke, Barbara (Hrsg.): Pursuit of Meaning. Advances in Cultural and Cross-Cultural Psychology, Bielefeld 2006, S.163-213

${ }^{10}$ Glaser, Barney G./Strauss, Anselm L.: The discovery of grounded theory: strategies for qualitative research, Chicago 1967; Glaser, Barney G./Strauss, Anselm L.: Grounded Theory. Strategien qualitativer Forschung, Bern [u.a.] 1998

11 Strauss, Anselm L./Corbin, Juliet: Basics of qualitative research. Grounded theory procedures and techniques, Newbury Park 1990

12 Weidemann, Doris/Straub, Jürgen: Psychologie interkulturellen Handelns, -in: Straub, Jürgen/Kochinka, Alexander/Werbik, Hans (Hrsg.): Psychologie in der Praxis. Anwendungs- und Berufsfelder einer modernen Wissenschaft, München 2000, S.830-855, S.835
} 
kens, Fühlens etc.). Sie ist umgekehrt aber auch das Produkt der menschlichen Praxis."

Entscheidend ist mithin nicht, welcher Nationalität die Akteure sind oder welche Sprache sie sprechen, sondern ob und in welcher Hinsicht Kulturteilhabe bzw. -differenz in der Interaktion relevant werden. Theoretische Grundlage ist dabei ein Kulturbegriff, der ,Kultur ${ }^{6}$ als kollektiv geteiltes Sinn- und Bedeutungssystem versteht, das Denken und Handeln ihrer Mitglieder in seinen Möglichkeiten vorstrukturiert. ${ }^{13}$

Aus dieser Definition ergibt sich, dass Bedeutung immer sozial (ko)konstruiert, mithin immer ,kulturell' ist, womit auch Handlung als immer kulturell zu bezeichnen ist und - wie Gertrude Anscombe es ausgedrückt hat ${ }^{14}$ - immer schon unter einer Beschreibung steht.

Unter Handlung verstehe ich dabei mit Gabriel Layes Formen des SichVerhaltens, die nicht rein reaktiv, reflexhaft oder unwillkürlich ablaufen, sondern in denen sich ein zumindest potentiell bewusstseinsfähiges, willkürlich beeinflussbares und diskursivierbares Selbst-, Fremd- und Weltverhältnis ausdrückt. ${ }^{15}$ Somit ist „[i] edes Handeln ein Sich-Verhalten, keineswegs aber kann jedes Sich-Verhalten als Handeln bezeichnet werden“.16 Wesentliches Movens menschlichen Handelns ist dabei die Regulation des von Boesch so bezeichneten „Handlungspotentials“. ${ }^{17}$ Das subjektiv empfundene Gefühl, handeln zu können, beeinflusst sowohl Handlungsziele als auch Handlungsorientierung und -steuerung. Aufgrund der Polyvalenz von Handlungszielen sowie der Überdeterminiertheit von Handlungen kann man Handlungen somit in Hans Joas' Worten als immer nur „diffus teleologisch“ bezeichnen, ${ }^{18}$ d.h. im Vollzug einer Handlung verändern sich notwendigerweise (und empirisch nachweisbar) sowohl Bewertung der Handlungssituation als auch in der Folge das Handlungsziel. ${ }^{19}$

Eine Handlung (und ihre Bedeutung/en) ist also nicht ohne soziale und damit kulturelle Einbindung denkbar, wobei diese nur zum Teil durch direkte Interaktion

\footnotetext{
13 Weidemann, Doris: Interkulturelles Lernen. Erfabrungen mit dem chinesischen ,Gesicht': Deutsche in Taiwan. Bielefeld 2004

14 Anscombe, Gertrude E.M.: Intention, Oxford 1985, S.11

15 Layes, Gabriel: Grundformen des Fremderlebens: Eine Analyse von Handlungsorientierungen in der interkulturellen Interaktion, Münster 2000, S.70

16 Straub, Jürgen: Handlung, Interpretation, Kritik - Grundqüge einer textwissenschaftlichen Handlungs- und Kulturpsychologie, Berlin-N.York 1999, S.12

17 Boesch, Ernst E.: Kultur und Handlung. Einfübrung in die Kulturpsychologie, Bern 1980; Boesch (1991)

18 Joas, Hans: Symbolischer Interaktionismus. Von der Philosophie des Pragmatismus zu einer soziologischen Forschungstradition, -in: Kölner Zeitschrift für Soziologie und Sozialpsychologie, 40, 1988, S.417446, S.423, zit. nach Alheit, Alheit, Peter: Neugier, Beobachtung, Praxis - Forschendes Lernen als Methode erziehungswissenschaftlichen Studierens, -in: Thon, Christine/Rothe, Daniela/Mecheril, Paul/Dausien, Bettina: Qualitative Forschungsmethoden im erziehungswissenschaftlichen Studium, Universität Bielefeld 2005, S.8, (http://bieson.ub.uni-bielefeld.de/volltexte/2006/810/html/Alheit.pdf)

${ }^{19}$ vgl. Boesch (1980), S.141ff.
} 
zwischen Menschen bestimmt wird. Grundsätzlich ist sie in symbolische Zusammenhänge eingebettet.

Dennoch sind soziale Interaktionen gewissermaßen die kleinsten Einheiten, aus denen Kultur entsteht und in denen kulturelle Differenz aufscheint, weshalb sie für die Untersuchung interkultureller Kommunikation von besonderem Interesse sind. Interkulturelle Interaktionen fasse ich dabei als spezifische Form sozialer Interaktionen, und zwar als solche, bei der kulturelle Differenz entweder von den Interaktionspartnern in der Interaktion oder von einem Beobachter hinsichtlich der Interaktion im Hinblick auf bestimmte Interessen relevant gesetzt wird. ${ }^{20}$

Interessiert man sich also für solche interkulturellen Interaktionen und spezifischer dafür, was dabei auf Seiten der Akteure geschieht, kann man den Fokus entweder auf die Interaktion selbst legen oder das Interaktionssetting bzw. - weiter gefasst - das pragma-semantische Netz als Möglichkeitsraum, in dem eine konkrete Interaktion einen Knoten darstellt, untersuchen. ${ }^{21}$

Ein Beispiel für ersteres Vorgehen sind die Arbeiten von Alex Gillespie, ${ }^{22}$ der touristische Interaktionen in Ladakh erforscht hat, wobei er sich auf die Mead'sche Unterscheidung von ,I' und ,Me' stützt. ${ }^{23}$ Anhand aufgezeichneter Gruppengespräche mit Touristen bzw. Ladakhis über im touristischen bzw. ladakhischen Kontext relevante Aspekte wie Modernisierung/Entwicklung versus Tradition, Wahrnehmung von Touristen bzw. Ladakhis etc. zeichnet Gillespie nach, an welchen Stellen in den Narrationen und Argumentationen aufgrund von Perspektivenwechsel eine Veränderung im Selbstkonzept der Interviewpartner stattfindet. Da es sich bei den betrachteten Aussagen oft um Aussagen über Interaktionen handelt, interpretiert Gillespie den Perspektivenwechsel als ,returning surplus' der Interaktion selbst.

Gillespie untersucht also konkrete Interaktionen auf den durch die Interaktion hervorgerufenen Bedeutungsüberschuss hin, der das Selbstkonzept der Erzähler

\footnotetext{
${ }^{20}$ vgl. Weidemann, D. (2004), S. 34; Weidemann, Arne. Pragma-semantische Analysen zur Erforschung interkultureller Kommunikation, -in: FQS, (Themenschwerpunkt „Qualitative Forschung zur interkulturellen Kommunikation"), 01/2009

${ }^{21}$ Zur pragma-semantischen Analyse und der damit verbundenen Terminologie siehe ausführlicher Weidemann (2009).

22 Gillespie (2004a); Gillespie, Alex (2004b): Symbolic adaptation to uncertainty: tourists buying souvenirs in Ladakh, North India, Paper presented at ISSBD 18th biennial conference, Gent Belgium, 15th July 2004; Gillespie (2006a); Gillespie, Alex (2006b): The Striving Tourist In Ladakh, North India, -in: Simão, Livia Mathias/ Valsiner, Jaan: Otherness in Question: Labyrinths of the Self, Charlotte, N.C. 2006, S.163-186; Gillespie, Alex (2006c). Tourist Photography and the Reverse Gaze, -in: Ethos, 34, 3, 2006, S.343-366; Gillespie, Alex: Collapsing Self/Other positions: Identification through differentiation, -in: British Journal of Social Psychology, 2007, S.1-7

${ }^{23}, \mathrm{Me}^{6}$ und ,I' bilden in der Mead'schen Identitätstheorie das Selbst. Vereinfacht ausgedrückt bezeichnet ,Me' das ,reflektierte Ich', insofern, als man sich hier aus der Perspektive des generalisierten Anderen sieht; es handelt sich um die ,sozialisierte' Instanz des Selbst. Als ,I‘ bzw. ,impulsives Ich bezeichnet Mead die vorsoziale, subjektive Instanz des Selbst. Im Handeln kommen beide Instanzen zusammen.
} 
verändert, wobei er sieben touristisch bedeutsame Haupthandlungen bzw. -interaktionen ausmacht. ${ }^{24}$

Da konkrete Handlungen und damit auch Interaktionen jedoch nie losgelöst von ihrem Kontext existieren, sondern immer in komplexe Handlungszusammenhänge eingebettet sind, die in vielfältiger Weise über die konkrete Situation hinausweisen, ist es für das Verstehen von Handlungen nötig, möglichst viel über eben diese Zusammenhänge zu wissen.

Konzeptualisieren lässt sich das als Netzwerk, in dem einzelne Handlungen immer nur Teil von Handlungsketten sind bzw. mit anderen Handlungen insofern vernetzt sind, als sie Anlass, Ziel oder irgendwie beeinflussender Faktor anderer Handlung sind oder sein können. Dieses pragma-semantische Netzwerk stellt dann gewissermaßen den ,hermeneutischen Möglichkeitsraum‘ dar, in dem Handlungen stattfinden. Die Untersuchung dieses Möglichkeitsraumes ist dann bedeutsam, wenn man sich dafür interessiert, was Akteure verstehen und wie sie handeln könnten. Im hier interessierenden Kontext also auch, welche Möglichkeiten es z.B. für interkulturelles Lernen geben könnte.

Wie sich aus dem Gesagten schon ergibt, ist das pragma-semantische Netzwerk aus einer Metaperspektive betrachtet prinzipiell unabschließbar und potentiell endlos, und jede individuelle Sicht (auch die des Beobachters) stellt notwendigerweise nur eine perspektivisch gebundene Sichtweise auf einen von vielen möglichen Ausschnitten unter Berücksichtigung nur einiger von potentiell unendlich vielen Knoten und Vektoren dar. Wichtig ist, dass es hier nicht um kausalistische Handlungserklärungen geht, sondern darum, explizierte bzw. potentielle Bedeutungszusammenhänge zu erschließen, in denen Menschen handeln, d.h. zu ergründen, aus welchen Quellen bzw. Symbolbeständen individuell wie kollektiv verfügbare oder potentiell verfügbare denotative wie konnotative Aspekte von Handlungen stammen und wie dies in interkulturellen Interaktionen zum Tragen kommt. ${ }^{25}$

\section{Sehnsucht und Imagination}

Zur Vorbereitung des empirischen Beispiel meines Textes möchte ich den Zusammenhang zwischen Reisen mit Sehnsucht und Imagination skizzieren.

Wie Christoph Hennig in seinem Buch Reiselust schreibt, ist der ,touristische Blick [...] seit jeher ,unrealistisch“",26 durchzieht die „Suche nach Traumwelten [...] alle Formen und Epochen der modernen Urlaubsreise“, ${ }^{27}$ war die ,selektive, fiktionale Wahrnehmung [...] von Anbeginn ein struktureller Bestandteil des Tou-

\footnotetext{
${ }^{24}$ Im Einzelnen handelt es sich um den ,sightseeing act“, den „being-toured act“, den ,guiding act“, den „eliciting-photographs act“, den „photographing act“, den „,serving act“ und den „,buying act“, Gillespie (2004a), S.59ff.

25 s.a. Weidemann, A. (2009)

${ }^{26}$ Hennig (1999), S.57

27 ebd, S. 58
} 
rismus, unabhängig vom Bildungsstand und der sozialen Position der Reisenden". 28

Im Zusammenhang mit Tourismus sind es vor allem positive individuelle wie kollektive Fantasien und Wunschvorstellungen, in denen Sehnsüchte zum Ausdruck kommen und die - wie Hennig ausführt ${ }^{29}$ - touristisches Reisen schon immer stärker geprägt haben als der Wunsch, Fremdes tatsächlich zu erkennen. Vielmehr suchten Touristen ,die sinnliche Erfahrung imaginärer Welten, die Realität der Fiktion“, 30 seien sie bestrebt ,aus Literatur, Kunst, kollektiver Phantasie bekannte Bilder in der materiellen Realität wiederzufinden. "31 Insofern diesen Bildern kollektiv geteilte wie individuelle Wünsche und Sehnsüchte zugrunde liegen, ist es kaum verwunderlich, dass Reisende diesen dann folgen und physische wie kognitive Anstrengungen unternehmen, damit sie das finden, wonach sie sich sehnen. ${ }^{32}$ Die psychische Notwendigkeit, das Urlaubsziel so zu erleben, wie man es sich vorgestellt hat, ist dabei - wie etliche Studien ausweisen - nicht selten so stark, dass die Fantasien aufrechterhalten werden, selbst wenn die Realität des besuchten Landes deutlich davon abweicht. ${ }^{33}$ Dies gelingt einerseits durch die Gestaltung des „tourist space“"34 mit seiner konstruierten Authentizität (die sich an den Fantasien der Besucher oft mehr als an der Realität der Besuchten orientiert und Aspekte letzterer nur als Versatzstücke benötigt). ${ }^{35}$ Andererseits werden ,unpassende ${ }^{6}$ Aspekte oft gar nicht erst wahrgenommen bzw. in ihrer Bedeutung unterschätzt. Eine spezifische Bedeutung erlangt dabei die Produktion passender ,Eindrücke' durch die Touristen selbst, die durch ihre Berichte und Bilder die „Realität der Fiktion“36 dokumentieren und damit nicht nur ihre individuellen Fantasien, sondern eben auch kollektive Fiktionen perpetuieren.

Sieht man die fiktionale Seite des Tourismus (und seine unrealistische Darstellung des Anderen) mit Hennig nicht als Defekt, der den Touristen - wie dies üblicherweise geschieht - als moralischer Makel angelastet werden muss, eröffnen sich für die Erforschung interkultureller Kommunikation weit reichende und die Theoriebildung erweiternde Perspektiven.

Das Verhältnis von Touristen zu kultureller Differenz ist in spezifischer Weise durch stereotype Wunschvorstellungen und kollektive Fantasien (mit)geprägt in

\footnotetext{
28 ebd.; vgl. auch Löfgren, Orvar: On Holiday. A history of vacationing, Berkeley-Los Angeles- London 1999

${ }^{29}$ Hennig (1999), S.55ff.

30 ebd., S.55

31 ebd., S.58, Hervorh. im Orig.

32 vgl. Boesch, Ernst E.: Sehnsucht: von der Suche nach Glück und Sinn, Bern 1998

33 siehe z.B. Fischer, Hans: Warum Samoa? Touristen und Tourismus in der Südsee, Berlin 1984; Weiß, Martin: Studienreisen nach Marokko. Angebote, Teilnehmerkreis, Reisemotive, Images, Passau 1998; Popp, Herbert: Reisen bildet - Klischees bleiben, -in: Forschung Spezial, 2004, S.56-59

${ }^{34}$ MacCannell, Dean: The Tourist. A New Theory of the Leisure Class. New York 1976

35 siehe z.B. Schmidt, Bernd Oliver: Der Orient - Fantasia 1001 Nacht. Wie Touristen Fremdes sehen und verstehen, Starnberg 2001

${ }^{36}$ Hennig (1999), S.55
} 
einer Art und Weise, die geeignet erscheint, tatsächliche kulturelle Differenz zu ,überformen'. Anders gesagt: für einen Touristen ist es weniger wichtig zu erfahren, wie der Andere tatsächlich ist (als Individuum), als dass er dem mitgebrachten Bild (von dem ,Marokkaner', dem ,Ladakhi' etc.) entspricht. Anders etwa als in der Geschäftskommunikation, wo kulturelle Differenz in der Regel eine ,Problemzone darstellt, ist kulturelle Differenz im Tourismus nötig, damit die Sehnsucht eine Projektionsfläche hat und der Urlaub (als gesellschaftlich sanktionierte Möglichkeit, Sehnsüchten nachzugeben) gelingen kann. Das bedeutet aber auch, dass die kulturelle Differenz bestimmte - bekannte und positive - Formen anzunehmen hat. Dasselbe gilt auch für die Vorstellung und Wahrnehmung von interkulturellen Interaktionen.

Neben der Beobachtung von Interaktionen ist die Analyse symbolischer Repräsentationen touristischer Praxis somit von erheblicher Bedeutung, auch deshalb, weil die Akteure selbst allenthalben mit Objektivationen und Objektivierungen dieser Praxis konfrontiert sind. Hierzu zählen wie schon angedeutet sowohl schriftliche (z.B. Reiseberichte, Reiseführer) und bildliche (z.B. Fotos, Film, Zeichnungen) als auch auditive (z.B. Erzählen, Musik) und objektale (z.B. Souvenirs) Formen. Als touristische Medien kann man insbesondere Reiseführer, Reiseberichte, TVDokumentationen, Tourismuswerbung, Reiseprospekte und Kataloge der Touristikunternehmen bezeichnen, ${ }^{37}$ die in hohem Maße dazu dienen, das Reiseverhalten (potentieller) Touristen zu beeinflussen, darüber hinaus aber auch Auskunft über kollektiv geteilte Sehnsüchte und soziokulturelle Hintergründe einer Gesellschaft geben. ${ }^{38}$ Auffallend ist dabei die hohe Stereotypizität der Darstellungen einerseits und ihre inhaltliche Engführung auf Exotik andererseits. ${ }^{39}$

Darüber hinaus wird im mündlichen wie schriftlich fixierten Erzählen (kulturelle) Differenz sowohl konstituiert und konstruiert, als auch überbrückt, ${ }^{40}$ sodass bei der (Re)Konstruktion des pragma-semantischen Netzes insbesondere konnotative Verknüpfungen zwischen einzelnen Objektivationen als faktisch vorhanden nachgezeichnet bzw. als möglich hergestellt werden.

\footnotetext{
${ }^{37}$ vgl. Kagelmann, H. Jürgen: Touristische Medien, -in: Hahn, Heinz/Kagelmann, H. Jürgen (Hrsg.): Tourismuspsychologie und Tourismussoziologie: ein Handbuch zur Tourismuswissenschaft, München 1993, S.469479

38 siehe z.B. Selwyn, Tom (ed.): The Tourist Image. Myths and Myth-making in Tourism, Chichester [u.a.] 1996; Kortländer, Kristina: Das Land des Lächelns. Thailand als Mythos in Reisekatalogen, MünsterHamburg-London 2000; Schellhorn, Matthias/Perkins, Harvey C.: The stuff of which dreams are made: Representations of the south sea in german-language tourist brochures, -in: Current issues in tourism, 7 (2), 2004; S.95-133; vgl. auch Loenhoff, Jens: Medien, -in: Straub/Weidemann/Weidemann (2007), S.534-543

${ }^{39}$ vgl. Opaschowski, Horst W.: Das gekaufte Paradies. Tourismus im 21. Jabrhundert, Hamburg 2001; siehe auch. die Studien von Bertram, Jutta: „Arm, aber glücklich ... ": Wahrnehmungsmuster im Ferntourismus und ibr Beitrag zum (Miss-)Verstehen der Fremde(n), Münster [u.a.] 1995; Kortländer (2000); Schmidt (2001); Weiß (1998)

40 Boesch, Ernst E.: Von Kunst bis Terror. Über den Zwiespalt der Kultur, Göttingen 2005, S.169ff.
} 


\section{Fremdbild und Eigensinn: Touristische Fremdkonstruktionen am Beispiel ,Ladakh'}

Aus Platzgründen kann ich das folgende empirische Beispiel leider nur in Ansätzen entfalten. Statt die einzelnen Quellen in der eigentlich gebotenen Ausführlichkeit für sich selbst sprechen zu lassen und lediglich konnotative Verknüpfungen zwischen ihnen herzustellen, werde ich mich etwas knapper fassen und wesentliche Aspekte als ,Knoten“ des (re-)konstruierten pragma-semantischen Netzes teilweise nur benennen.

Den Fokus meiner Betrachtungen möchte ich auf die touristische ,Verwertung zweier religiöser Veranstaltungen legen, die ich im Februar 2005 im Rahmen meiner Feldforschungen ${ }^{41}$ in Ladakh beobachtet habe: das buddhistische Klosterfest Matho Nagrang sowie die shiitische Zuljehnah-Prozession im Rahmen von Aschura.

Für das Verständnis der folgenden Ausführungen ist es dennoch wichtig, einige Worte zu Ladakh als Reiseziel zu verlieren ${ }^{42}$, wobei ich aus dem Katalog von Studiosus Reisen (2005) ${ }^{43}$ zitiere, wo es über die Reise Ladakh - Land der Klöster heißt:

„Isoliert durch die Hauptkette des Himalayas, hat sich am Oberlauf des Indus eine tibetische Mönchskultur erhalten. Vor der Kulisse schneebedeckter Gipfel liegen zahlreiche Klöster, die nicht nur Zeichen einer tiefen Frömmigkeit, sondern auch Zentren des sozialen und wirtschaftlichen Lebens sind. Im Dämmerlicht der Tempel stehen goldene, von Butterlampen erleuchtete Sakralfiguren, an den Wänden hängen kunstvolle buddhistische Rollbilder, und über allem klingt der gleichmäßige Gesang tief in Meditation versunkener Mönche“.

\footnotetext{
${ }^{41}$ Meiner wissenschaftlichen Beschäftigung mit Ladakh gingen mehrere längere Reisen nach Ladakh voraus (zwischen 1988-1991 und 1993, vornehmlich im Winter). Ab 2004 habe ich drei Feldforschungsreisen nach Ladakh unternommen (2004, 2005, 2007), während denen ich teilnehmend beobachtet und zahllose Gespräche mit Ladakhreisenden wie anderen Akteuren im Feld geführt habe. Im Rahmen meiner Arbeit führe ich zudem umfangreiche Medienanalysen (Reiseführer, Reiseveranstalterkataloge, Reiseberichte, Weblogs, Zeitschriften- und Zeitungsberichte, wissenschaftliche Publikationen sowie Dokumentar- und Spielfilme) durch.

42 Die Ausführungen ließen sich trefflich durch Fotos illustrieren, die den stereotypen Charakter der Texte auch visuell untermauern würden. Die Recherche in Reiseführern und Bildbänden aber auch Weblogs und öffentlich gehaltenen Diavorträge etc. offenbart, dass gleiche oder ähnliche Motive und Blickwinkel bis hin zu bestimmten Lichtverhältnissen und Bildstimmungen immer wieder vorkommen, es also gerechtfertigt ist, von visuellen Stereotypen zu Ladakh zu sprechen. Die Funktion dieser visuellen Stereotype im touristischen Kontext wird weiter unten kurz beleuchtet; siehe auch z.B. die Studie von Schmidt (2001).

${ }^{43}$ Studiosus Reisen München GmbH: Expeditionsstudienreise: Ladakh - Land der Klöster, München 2005 (S. 76f.)
} 
Sigl Erlebnisreisen (2005) beschreibt seine Gruppenreise „Ladakh \& Zanskar“ wie folgt: 44

„Diese beeindruckende Trekkingtour vereint Natureindrücke aus den wilden Himalayaregionen Zanskars mit den schönsten Klosterbesichtigungen. Hinter den hohen Pässen liegen die majestätischen Klöster mit ihrer unverändert erhaltenen tibetischen Kultur und den so ausgeglichenen, freundlichen Menschen. In Ladakh erleben Sie hautnah den Kontrast zwischen bizarren, wilden Schluchten, rauschenden Flüssen, atemberaubenden Brücken und eisigen Gipfeln. Hier ist der buddhistische Glaube allgegenwärtig und die Klöster sind voller Leben“.

Und Ikarus Tours bewirbt die „Klassische Ladakhrundreise“ folgendermaßen: „Ladakh, seit 1974 für Auslandsbesucher geöffnet und damals eine BesucherSensation, ist ein integraler Teil Tibets. Eine grandiose Hochgebirgslandschaft, die ladakhischen Klöster, die Gompas, oft auf bizarren Bergflanken errichtet, vor allem hier eine lebendige lamaistische Religion. Ladakh, ein idealtypisches Tibet, weil hier - im Gegensatz zum eigentlichen Tibet - keine Usurpation durch eine wesensfremde Kultur und Macht statfand". (2005, Hervorhebungen im Original) ${ }^{45}$

Ergänzen möchte ich diese Eindrücke durch einige Fakten ${ }^{46}$, die einer architekturethnografischen Präsentation über Ladakh entnommen sind, wobei sich die gleichen Informationen auch wieder in vielen verschiedenen anderen Medien zu Ladakh finden:

„Ladakh ist eine Region im östlichen Teil des nord-indischen Bundesstaates Jammu \& Kashmir und liegt eingebettet zwischen dem Himalaja- und dem Karakorum-Gebirge. Ladakh ist ein Teil der tibetischen Hochebene und damit eines der höchst gelegenen bewohnten Gebiete der Erde. Bereits die Hauptstadt Leh liegt auf $3.500 \mathrm{~m}$ Höhe, die Dörfer befinden sich zwischen 3.500 und 4.500 $\mathrm{m}$, die höchsten Erhebungen ragen weit über $7.000 \mathrm{~m}$ hinauf. Ladakh hat eine Größe von $59.000 \mathrm{~km}^{2}$ (exkl. der von Pakistan und China besetzten Territorien) und ca. 205.000 Einwohner (Einwohnerdichte: 2,6 EW $/ \mathrm{km}^{2}$ ), wovon ca. 23.000 in der Hauptstadt Leh leben. Ladakh lässt sich in folgende Territorien gliedern:

\footnotetext{
44 Aus dem Reiseinformationsblatt (Indien, Reise Nr.: 200180) des Reiseveranstalters Sigl Erlebnisreisen (2005). Unter derselben Reise-Nr. wird derzeit eine ähnliche Reise, allerdings mit etwas geändertem Text angeboten (http://www.erlebnisreisen-weltweit.de/reisetipp-200180.html, Zugriff 22.09.2010)

45 Ikarus Tours wirbt damit, dass diese Reise seit 1975 („mit Modifikationen“) im Programm sei. Online unter http://www.ikarus.com/web/index.cfm/pm/detail/idobjekt/43017/idreiseart/38 /web/Klassische-Ladakh-Rundreise-mit-Kaschmir.htm (Zugriff 22.09.2010).

${ }^{46}$ Es sei hier auf die etymologischen Wurzeln des Wortes ,Fakten' (von Lat. , facere ${ }^{6}=$,machen') hingewiesen, um zu verdeutlichen, dass man es auch da, wo es um die vermeintlich objektive Beschreibung, natürlicher' Gegebenheiten handelt, mit etwas ,Gemachtem‘ im Sinne des Bruner'schen ,meaning making' (1990) zu tun hat. Siehe zum Verhältnis von ,Daten` und ,Fakten` in der empirischen Sozialforschung Appelsmeyer, Heide/Kochinka, Alexander/Straub, Jürgen: Qualitative Methoden, -in: Straub, Jürgen/Kempf, Wilhelm/Werbik, Hans (Hrsg.): Psychologie - Eine Einführung. Grundlagen, Methoden, Perspektiven, München 1997, S.709-742, S.715.
} 
das Industal, das Zanskar Tal, das Suru Tal, Nubra, das Do-Hannu Gebiet, das Chang Than Plateau und die dazwischenliegenden Bergketten. 1979 wurde Ladakh in zwei administrative Distrikte geteilt: Distrikt Leh und Distrikt Kargil. Das trockene Hochwüstenklima mit einer Niederschlagsmenge von nur 10 $\mathrm{cm} / \mathrm{Jahr}$ beschert der Region heiße Sommer mit bis zu $35^{\circ} \mathrm{C}$ und kalte Winter mit bis zu $-25^{\circ} \mathrm{C}$. Nur 0,4 \% der Fläche ist kultivierbar" ${ }^{\text {" }}{ }^{7}$

Auf einem Gebiet, das etwa dreimal so groß ist wie das Bundesland Sachsen, leben also heute über 205.000 Menschen, und nur 0,4\% der Gesamtfläche sind kultivierbar, nämlich da, wo Gletscherbäche für ausreichende Feuchtigkeit sorgen. In der kalten Hochwüste Ladakhs beträgt die Niederschlagsmenge durchschnittlich $10 \mathrm{~cm}$ im Jahr - soviel regnet es an vielen Orten in Deutschland in manchen Jahren allein im März.

Die topografischen und klimatischen Gegebenheiten sorgen dafür, dass die zum Teil deutlich über 5000 Meter hoch gelegenen Passstrassen nur während der Sommermonate für Fahrzeuge passierbar sind. Die übrigen 7 bis 8 Monate im Jahr ist Ladakh lediglich zu Fuß oder per Flugzeug erreichbar.

Die abgeschiedene Lage, die besonderen Lebensbedingungen, die buddhistische und Bön-Tradition machen Ladakh für Ethnologen und Buddhismusforscher überaus attraktiv, nicht zuletzt weil Tibet viele Jahre für westliche Besucher gar nicht zugänglich war und viele der Klöster dort im Zuge der chinesischen Kulturrevolution zerstört und religiöse Praktiken z.T. bis heute verboten sind. Aber auch Zoologen, Pharmazeuten, Chemiker, Geologen usw., interessieren sich für die Region. So ist Ladakh aber vor allem auch für Touristen ein attraktives Reiseziel.

\section{Tab. 1: Touristenzahlen}

\begin{tabular}{|l|l|}
\hline 1976 & insgesamt 2.051 Touristen \\
\hline 1988 & 24.864 Touristen, darunter 16.256 Ausländer \\
\hline 1998 & 22.030 Touristen, darunter 15.238 Ausländer \\
\hline 2003 & 27.920 Besucher (bis Mitte Juli) \\
\hline 2004 & über 30.000 Besucher, zur Hälfte Ausländer \\
\hline 2007 & 50.185 Besucher, darunter 22.007 einheimische Touristen \\
\hline 2008 & 71.173 Besucher, darunter ca. 30.000 Ausländer \\
\hline 2009 & 77.898 Besucher, darunter 30.220 Ausländer \\
\hline \multicolumn{2}{|c|}{ Quellen: Dixit (1995); J®K Tourism Department, Leb (2008), Parvaiz (2009)48 }
\end{tabular}

${ }^{47}$ Lehner, Erich/Riegel-Jandl, Andrea: Himalayan Future. Land - Mensch - Architektur, Ausstellungsdokumentation, Wien: 2003, http://baugeschichte.tuwien.ac.at/ladakh/index.html (Zugriff 22.09.2010)

48 Dixit, Kanak Mani: Tourism trends and issues across the Himalaya, -in: Luger/Inmann (1995), S.203-222; siehe auch http://ladakhstudies.org/News_files/1f2bdf010bc45106d5daee03fa41d25e- 
Die Entwicklung des Tourismus ist nach der (Wieder)Öffnung Ladakhs für ausländische Besucher 1974 rasant gewesen, und mittlerweile besuchen jährlich über 70.000 indische und internationale Touristen die Region (s. Tab. 1).

Wie Sie unschwer erkannt haben, handelt es sich bei dieser kleinen Kollage weder um eine neutrale oder gar objektive Darstellung Ladakhs, noch um das Ergebnis einer datengesättigten Analyse verschiedenen empirischen Datenmaterials. Es handelt sich schlicht um eine weitere Repräsentation Ladakhs. Eine Repräsentation allerdings, mit der ich nicht nur auf Ladakh, sondern gleichzeitig auch auf die Selbst- und Fremdreferentialität solcher Repräsentationen verweisen möchte sowie auf deren in hohem Maße stereotype Verwendung bestimmter Bilder und Metaphern.

\section{Tab. 2: Bevölkerung (\%) nach Religion (1981) ${ }^{49}$}

\begin{tabular}{l|ll}
\hline Religion & Leh & Kargil \\
\hline Hindu & 2.99 & 2.26 \\
Sikhs & 0.27 & 0.23 \\
Muslims & 15.32 & 77.90 \\
Christians & 0.23 & 0.12 \\
Buddhist & 88.18 & 19.49 \\
Others & 0.01 & - \\
\hline Total & 100.00 & 100.00 \\
\hline
\end{tabular}

Auffällig ist, dass Ladakh in den medialen Darstellungen buddhistisch repräsentiert ist. Dass dies nicht den relativ zufällig ausgewählten Beschreibungen geschuldet ist, zeigen ausführlichere Medienanalysen, die allesamt das Bild eines überwiegend buddhistischen Ladakhs entwerfen. Erstaunlich ist dies angesichts der prozentualen Religionszugehörigkeit der Bevölkerung (Tab. 2), denn fast die Hälfte aller Ladakhis ist muslimisch (s. Tab. 2)..$^{50}$ Weniger erstaunlich ist dies, wenn man sich

13.html (Zugriff 27.10.2008); Parvaiz, Athar: A Famed Region's Triple Whammy of Environmental Bane, -in: IPS News, 18.11.2009, http://ipsnews.net/news.asp?idnews=49316 (Zugriff 21.09.2010).

49 Quelle: Digest of Statistics, Government of Jammu and Kashmir, 1997-98, S.22, zitiert nach Bora, Nirmala: Ladakh. Society and economy, New Delhi 2004, S.59

50 Interessanterweise ist die einseitige Repräsentation Ladakhs als buddhistisch nicht auf touristische Medien beschränkt. In etlichen wissenschaftlichen Darstellungen (insbesondere auch indischer Autoren) wird nämlich im Zusammenhang mit der Zusammensetzung der Bevölkerung der Region auf die Prävalenz muslimischer Haushalte im Kargil-Distrikt und die mit $15 \%$ große Minderheit der Muslime im Leh-Distrikt verwiesen, um diese jedoch dann geflissentlich zu ignorieren. So wird in der Regel als ,ladakhisch' ausschließlich ,buddhistische ${ }^{6}$ Praxis beschrieben, wobei die Muslime den ,buddhistischen' Ladakhis stillschweigend eingemeindet werden wie z.B. bei Kaul, Shridhar/Kaul, H. N.: Ladakh Through the Ages. Towards a New Identity, New Delhi 1995; oder Jina, Prem Singh: Ladakh. The Land of the People, New Delhi (1996); und Jina, Prem Singh (ed.): Ladakh. Past \& Present, New Delhi (2000); oder die muslimische Minderheit wird - wie zum Beispiel bei Bora (2004) - durch Gleichsetzung mit der christlichen Minderheit (weniger als $0,3 \%$ ) weiter marginalisiert. Diese relative Unbedeutsamkeit des Islam in Ladakh in medialen Repräsentationen der Region lässt sich also weder aus den Zahlen ableiten, noch aus der Geschichte Ladakhs, in der Muslime seit dem 14. Jh. eine Rolle 
die Repräsentationen genauer ansieht und die Kernthemen herausarbeitet. Es handelt sich dabei um die Themen Authentizität und Tradition, Exotik, unberührte, spektakuläre Landschaft, Abenteuer, Besonderheit und Mysterien etc. (s. Tab. 3).

\section{Tab. 3: Kernthemen ,Ladakh`}

\begin{tabular}{|ll|}
\hline Authentizität & (lebendige) Tradition \\
\hline Exotik & Religiosität/Spiritualität \\
\hline Mystik & Geheimnis/Wunder \\
\hline Besonderheit & Abenteuer \\
\hline Ursprünglichkeit & Natur/Bergwelt \\
\hline
\end{tabular}

Diese Kernthemen lassen sich als wichtige Bestandteile verschiedener ineinander verschachtelter Diskurse ausmachen, in die die Texte, aber auch die Besucher eingebunden sind, und die wiederum weitere Kernthemen bereitstellen, anhand derer sich die Repräsentation Ladakhs als buddhistisch besser verstehen lässt.

Die beiden in diesem Kontext wichtigsten Diskurse möchte ich versuchsweise und vorläufig bezeichnen als den Diskurs der Romantik und den Diskurs der Nachhaltigkeit, wobei sich sogleich zeigen wird, dass beide nicht unabhängig voneinander stehen, sondern sich über den Begriff der Sehnsucht miteinander verknüpfen lassen, und zwar der Sehnsucht nach einer besseren Welt, nach ShangriLa.

Der Begriff Shangri-La von James Hilton in seinem 1933 veröffentlichten und enorm erfolgreichen Roman Lost Horizon als Name für ein imaginatives paradiesisches Land im Himalaya erfunden, steht seither als Bezeichnung für - ich zitiere aus dem American Heritage Dictionary (1994): „1. An imaginary, remote paradise on earth; utopia. 2. A distant and secluded hideaway, usually of great beauty and peacefulness“" 51

Der Mythos von Shangri-La ist, wie Bishop ${ }^{52}$ in seinem gleichnamigen Buch ausführlich und lesenswert darstellt, eng mit Ideen verbunden, die in der Romantik v.a. auch in Deutschland entstanden sind. Einige dieser Ideen waren wesentlicher

den Zahlen ableiten, noch aus der Geschichte Ladakhs, in der Muslime seit dem 14. Jh. eine Rolle spielen, sondern nur als heutige interessengebundene diskursive Praxis und relationale Konstruktion begreifen (vgl. Bertelsen, Kristoffer Brix: Our Communalised Future. Sustainable Development, Social Identification and Politics of Representation in Ladakh, Aarhus University Diss., Aarhus1996; Van Beek, Martijn: The art of representation. Domesticating Ladakhi 'identity', -in: Lecomte-Tilouine, Marie/Dollfus, Pascale (Hrsg.): Ethnic revival and religious turmoil. Identities and representations in the Himalayas, New Delhi 2003

51 The American Heritage Dictionary, ${ }^{3} 1994$

52 Bishop, Peter: The myth of Shangri-La: Tibet, travel writing, and the western creation of sacred landscape, Berkeley 1989 
Bestandteil dessen, was Lütt ${ }^{53}$ das romantische Indienbild nennt und das er dem v.a. in England vertretenen utilitaristischen Indienbild gegenüberstellt. Verbindende Elemente des romantischen Indienbildes und des Shangri-La-Mythos sind buddhistische Philosophie und Religion, aber auch die inhärente Kritik am Eigenen, die sich in der Bewunderung des Fremden und der Sehnsucht danach ausdrückte. Während sich die Sehnsucht im Rahmen des romantischen Indienbildes vor allem in Form intellektueller und esoterischer Beschäftigung Erfüllung zu schaffen versuchte, erfordert der Mythos Shangri-La zur Erfüllung der Sehnsucht die Suche nach und die Reise an diesen Sehnsuchtsort ${ }^{54}$.

Wird Ladakh als Shangri-La bezeichnet - was tatsächlich sehr oft der Fall ist -, so schwingen hier verschiedene Elemente mit, nicht zuletzt die Idee Shangri-Las als "store house of world culture" wie Hutt es beschreibt" ${ }^{55}$. Zwar geht es im Zusammenhang mit der Repräsentation Ladakhs lediglich um die Bewahrung buddhistischer Kultur, doch wird selten vergessen, auf die Bedeutung der ,lamaistischen Traditionen als bedeutsame Exponenten der Weltkultur zu verweisen. Nach der umfassenden Zerstörung vieler tibetischer Klöster und ritueller Objekte, sowie dem weit gehenden Verbot ritueller Praktiken ist dies ein wichtiges Motiv für den Besuch Ladakhs. Denn dort ist die buddhistische Kultur - wie sich in vielen heutigen Ladakhdarstellungen finden lässt - noch lebendig und kann in authentischer Form im Alltag erlebt werden.

„Das Ausmaß, in dem eine Himalayaregion als Shangri-La empfunden wird [...] hängt davon $\mathrm{ab}$, in welchem Ausmaß sie unveränderte Elemente der verloren gegangenen tibetischen Authentizität bewahrt", schreibt Hutt ${ }^{56}$. Und in genau dem Maße, wie Shangri-La von ihm als bedroht wahrgenommen wird, muss der Tourist dann tätig werden: entweder, indem er sich bemüht, die vor Ort als authentisch empfundene Praxis zu retten, zu fördern oder aber zumindest nicht weiter zu zerstören - und/oder, indem er ein Bild von Ladakh produziert, in dem die Elemente authentischer Kultur intakt erscheinen können und bewahrt bleiben.

Wie sich schon im romantischen Indienbild, aber noch viel mehr im Mythos von Shangri-La ausdrückt, sind Buddhisten, noch dazu, wenn es sich um „mystische Lamas" handelt, die besseren Menschen, friedlich, freundlich und fröhlich im Umgang mit anderen Menschen, um Nachhaltigkeit bedacht im Umgang mit Umwelt und Universum.

Exotik, Authentizität, Unberührtheit, Nachhaltigkeit, spektakuläre Landschaft, Spiritualität, relative Unzugänglichkeit, Abenteuer etc. stellen zentrale Elemente

\footnotetext{
${ }^{53}$ Lütt, Jürgen: Deutschland, Indien und das deutsche Indienbild. Das romantische und das utilitaristische Indienbild Europas, -in: Der Bürger im Staat. Indien, (Landeszentrale für politische Bildung, Baden Württemberg), 48.Jg., H.1, S.60-64, Stuttgart 1998

${ }^{54} \mathrm{Zu}$ Sehnsuchtsorten siehe auch die Typologie von Wemhöner auf die hier aus Platzgründen nicht näher eingegangen werden kann; Wemhöner, Karin: Paradiese und Sebnsuchtsorte. Studien zur Reiseliteratur des 20. Jahrbunderts, Marburg 2004

${ }^{55}$ Hutt, Michael: Looking for Shangri-la: from Hilton to Lamichhane, -in: Tom Selwyn: The Tourist Image. Myths and Myth-making in Tourism, Chichester 1996, S.49-60, S.50 u.a.

56 ebd., S.53, eigene Übersetzung
} 
der westlichen Wahrnehmung und Faszination von Ladakh dar. In der Hoffnung, diese Elemente dort vorzufinden und damit die Sehnsucht nach dem Shangri-La, nach einer besseren, spirituelleren, weniger materialistischen Welt zu stillen, nehmen westliche Touristen große Strapazen auf sich, um die Region zu bereisen.

Man findet diese Elemente in (touristischen) Nutztexten wie Reiseprospekten, Reiseführern, aber auch in Dokumentar- und Spielfilmen sowie den Reiseberichten und Erzählungen von Touristen wieder, und sie sind sicherlich nicht rein zufällig mit Buddhismus und buddhistischer statt islamischer Praxis verknüpft ${ }^{57}$, decken sie sich doch in den Erwartungen westlicher Ladakhbesucher perfekt mit dem, was sie mit Buddhismus verbinden: Zum einen bedient der (tibetische) Buddhismus durch Accessoires wie Gebetsmühlen, Kataks, Masken, Chörten, Stupas, Buddhafiguren, Mandalas und Gebetsfahnen sowie durch Rituale wie das Singen von Mantras und Maskentänze das Motiv der Exotik und Esoterik, zum anderen symbolisiert er innere und äußere Ruhe, Spiritualität, Weisheit und Nachhaltigkeit im Umgang mit der Umwelt. Selbst die Landschaft wird - in bildlichen aber auch textlichen Darstellungen durch Chörten, Manimauern, Klöster und Gebetsfahnen etc. akzentuiert und noch spektakulärer gemacht - zu einer buddhistischen Landschaft. Sie wird nachgerade spiritualisiert und erfüllt damit wiederum die Sehnsucht nach einem transzendenten Zustand mystischer Verbundenheit mit einem erweiterten Selbst einerseits und einer endlosen Weite andererseits. An dieser durch die große Höhe und die Kargheit lebensfeindlichen Grenze der menschlichen Lebenswelt mit dem Universum wird ein transzendentaler Zustand gesucht und gefunden, symbolisiert z.B. durch meditierende Eremiten in einsamen Höhlen oder wehende Gebetsfahnen auf $5000 \mathrm{~m}$ hohen Pässen. Und dort ist man dann - wie es in einem kürzlich ausgestrahlten Dokumentarfilm zu Ladakh ${ }^{58}$ heißt - „der Heimat und dem Himmel ganz nah".

Mehr als die Tatsache, dass der Buddhismus vor dem Islam nach Ladakh kam, ist es diese Passung, die den Buddhismus in Ladakh in den Augen westlicher Besucher authentisch erscheinen, ja ,Ladakh' und ,Buddhismus' geradezu deckungsgleich werden lässt. Dies wiederum führt zu durchaus erstaunlichen Phänomenen. So finden zum Beispiel jedes Jahr mit dem Matho Nagrang ein buddhistisches Klosterfest als auch mit der Zuljenah-Prozession ein schiitisches Fest im öffentlichen Raum statt ${ }^{59}$. Während Matho Nagrang jedoch in touristisch relevanten Me-

\footnotetext{
${ }^{57}$ vgl. jedoch Frembgen, der sich mit der Darstellung des in Pakistan gelegenen Hunza in der Touristenwerbung beschäftigt. Auch Hunza wird (bzw. wurde) als Shangri-La (an)gepriesen, wobei hier neben anderen Faktoren, die auch für das benachbarte Ladakh gelten, die hohe Lebenserwartung der Bevölkerung eine Rolle spielt, Frembgen, Jürgen W.: Hunza und Shangri-la. Ein Bergvolk in der Touristenwerbung, -in: Münchner Beiträge zur Völkerkunde 2, 1989, S.51-68

${ }^{58}$ Ladakh, dem Himmel so nab-Leben im Himalaya, ein Film von Alexander Flucht, 2004 in der ARDReihe „Länder-Menschen-Abenteuer“ gesendet, auf 3SAT im März 2007 wiederholt.

59 Siehe zu letzterem die ausführliche und sehr kenntnisreiche Studie von Pinault, der sich intensiv mit den religiösen, soziokulturellen und politischen Aspekten der Zuljenah-Prozession in Ladakh auseinandergesetzt hat; Pinault, David: Horse of Karbala. Muslim devotional life in India, New York: 2001. Interessant sind in diesem Zusammenhang auch die Untersuchungen von Grist zum Verhältnis
} 
dien recht umfassend repräsentiert ist und von etlichen Reiseveranstaltern explizit beworben wird, sucht man Referenzen auf das schiitische Fest weitgehend vergeblich.

Das jährlich stattfindende zweitägige Matho Nagrang im Kloster Matho, das etwa $30 \mathrm{~km}$ von Leh entfernt liegt, ist berühmt durch die beiden in Trance versetzten Mönche, die als Orakel fungieren. Darüber hinaus finden dort Cham-Tänze statt, bei denen Mönche in z.T. sehr alten Masken und Gewändern rituelle Tänze aufführen (s. Abb. 1). In Reiseführern beschrieben wird es z.B. wie in folgendem Ausschnitt aus dem im Jahr 2000 überarbeitet neu aufgelegten Reiseführer Ladakh und Zanskar aus dem Reise Know-how Verlag. ${ }^{60}$ Dort heißt es im Abschnitt zu Matho unter der Überschrift „Orakelfest“":

„Besonders interessant ist das Dorfkloster nicht, es ist aber in ganz Ladakh berühmt wegen seines im Februar stattfindenden Orakelfestes. Tausende von Ladakhis nehmen oft lange Wege in Kauf, damit sie dabei sind, wenn zwei Mönche des Klosters sich in die zornvollen Schutzgottheiten Rongtsan verwandeln. An diesem Tag sagen sie die Zukunft voraus und beschwören die bösen Geister.

Auf dem Höhepunkt des Festes tanzen die beiden Mönche in Trance mit verbundenen Augen auf dem Klosterdach. Schließlich behängen sie sich mit Schwertern und Messern und schneiden sich damit tiefe Wunden in die Zunge - die Wunden sind nach einer Stunde völlig verheilt! Die Schutzgottheit Rongtsan gilt in Ladakh als besonders energievoll und wurde zur Zeit der Monarchie bereits als Staatsorakel verehrt.

Man mag an die Existenz solcher Götter glauben oder nicht. Aber es ist doch beeindruckend, welche immensen Fähigkeiten durch intensive Meditation entwickelt werden können. Die beiden Männer leben nämlich zwei Monate lang vor ihrem großen Auftritt in völliger Zurückgezogenheit und geistiger Versenkung“.61 


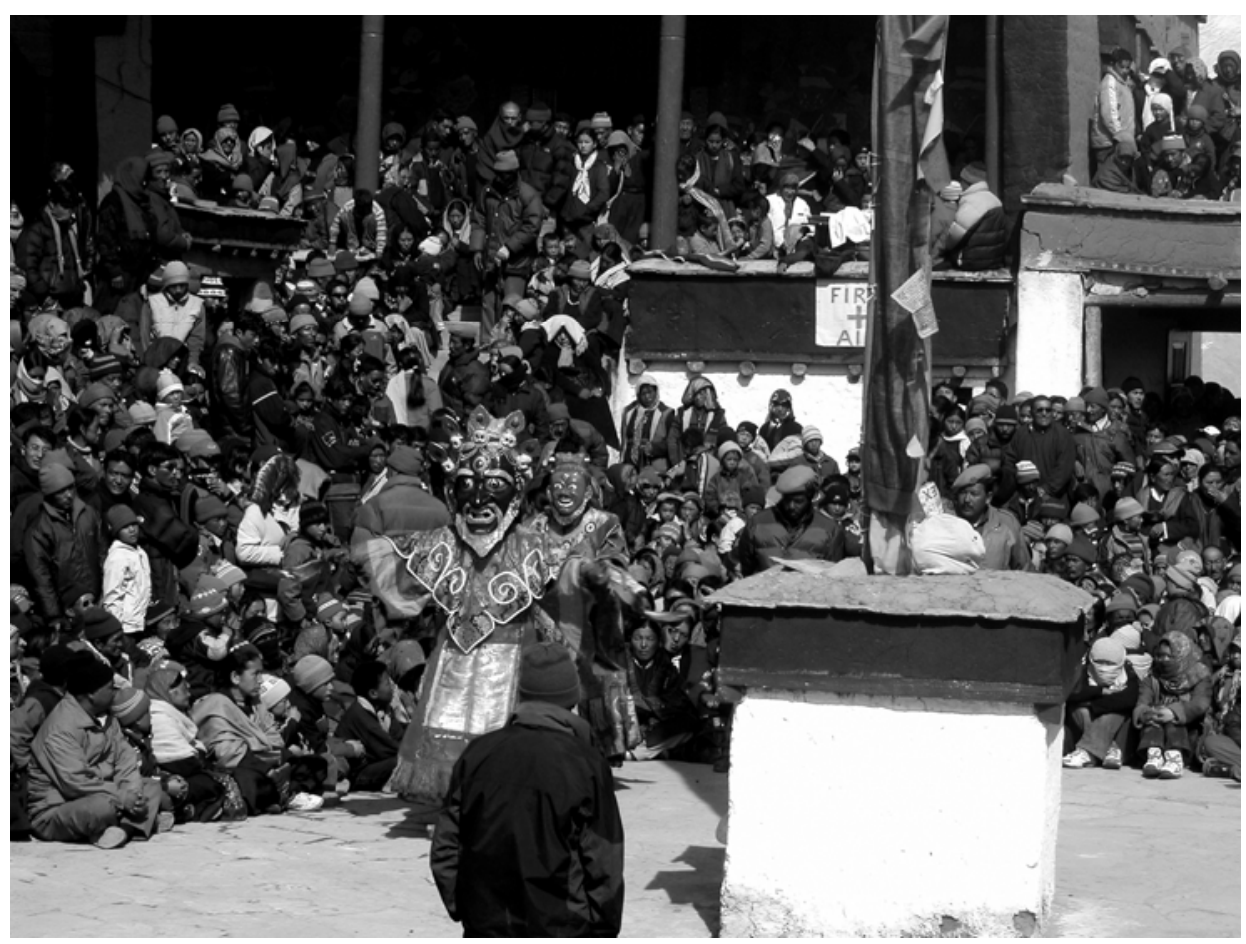

Abb. 1: Cham-Tan₹ im Innenhof der Matho-Gompa während Matho Nagrang. (Foto AW, 23.02.2005) 


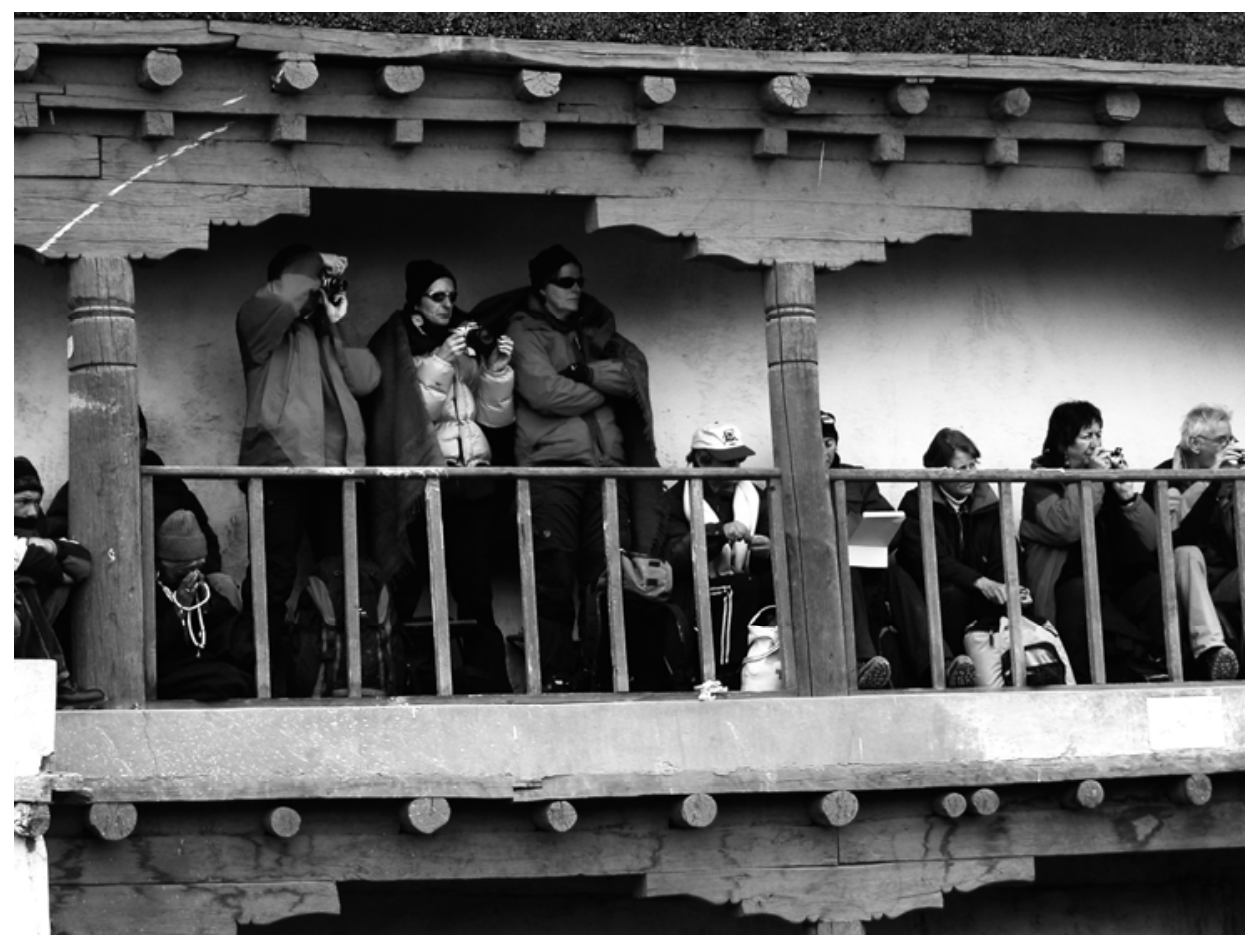

Abb. 2: Matho Nagrang. Während sich die Ladakhis im Klosterhof drängen (s. Abb.1), sitzen die westlichen Touristen überwiegend auf den Balkons auf Stüblen oder auf dem Klosterdach. (Foto $A W$, 23.02.2005)

Während man, um das Matho-Fest zu sehen, eine einstündige Busfahrt auf sich nehmen muss, kann man die Zuljehnah-Prozession zu Aschura nicht übersehen, wenn man sich an dem entsprechenden Tag in Leh auf die Straße begibt (s. Abb. 3). Die Prozession unterbricht nicht nur den normalen Alltag auch von Touristen, sondern stellt auf unvorhergesehene Weise auch ihr Selbst- und Fremdverhältnis in Frage. 


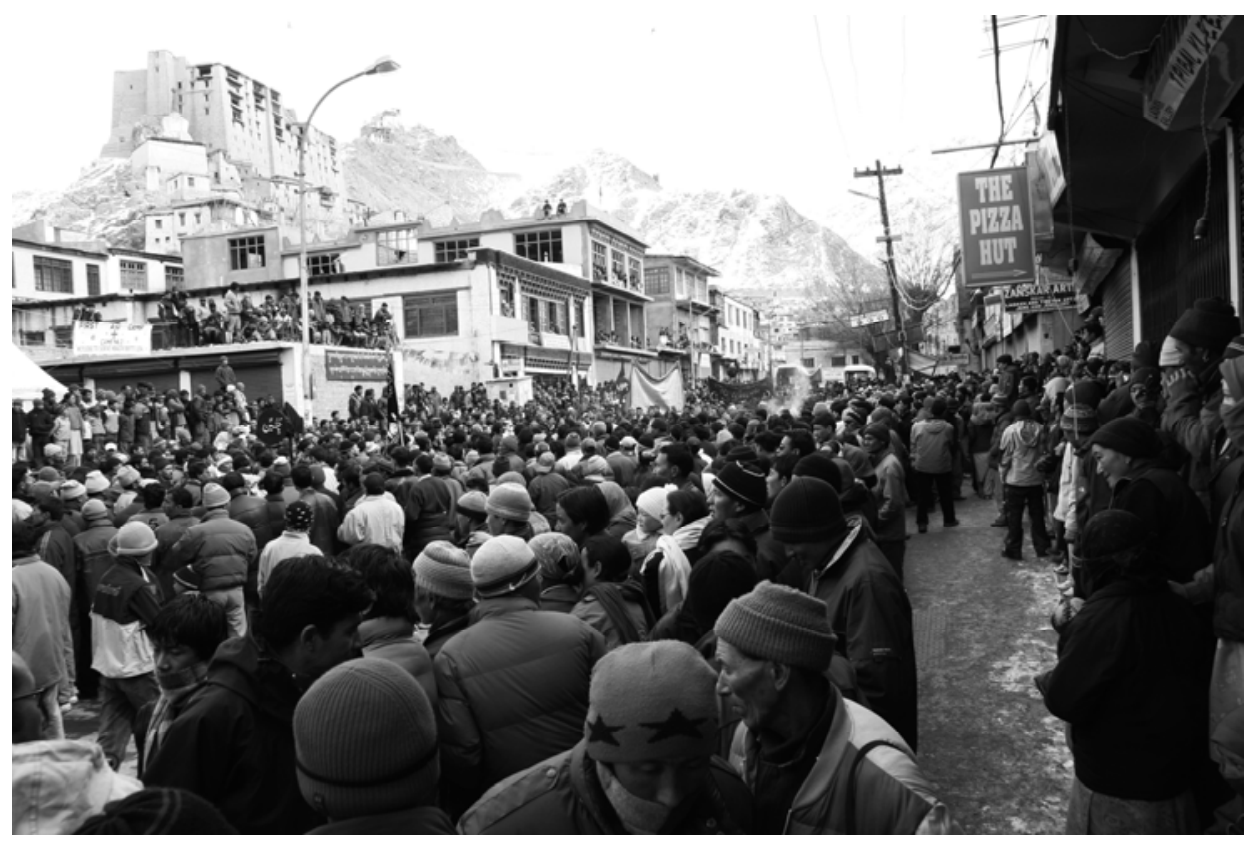

Abb. 3: Main Bazaar in Leh während der Zuljenab-Prozession. Wäbrend sich muslimische Ladakhis auf der Straße drängen, halten sich buddhistische Zuschauer im Hintergrund oder sehen von den Hausdächern aus zu. (Foto $A W, 20.02 .2005)$

Aschura (von arab.: , aschara ${ }^{6}=$,zehn') nennt man das jährliche, zehn Tage dauernde, schiitische Trauer- und Bußritual um Hussain, den Sohn Alis und Fatimas, der Tochter des Propheten Mohammeds. Die Aschura-Riten bilden den Höhepunkt des islamischen Monats Muharram. Während Aschura gedenken die Schiiten öffentlich der Schlacht von Kerbela im heutigen Irak. In dieser Schlacht wurden am 10. Tag des Monats Muharram Hussain, der dritte Imam der Schiiten, sowie fast alle männlichen Verwandten im Krieg getötet. Die Rituale des Aschura enthalten Erzählungen, Trauerprozessionen in Trauerkleidung und mit Selbstgeißelung oder auch die kultische Inszenierung des Martyriums Hussains. Die öffentliche Trauer ermöglicht es den Gläubigen am Leiden Hussains teilzuhaben und somit einen Teil ihrer individuellen Sünden abzubüßen.

Bereits vor dem Tag der Prozession waren in der Hauptstraße von Leh Banner gespannt und der Shi'a Matam Serai geschmückt, konnte man Gruppen von Muslimen die Fahrbahn sorgfältig von Müll befreien, das letzte Eis wegkratzen und mit Wasser abwaschen sehen. Am Abend vorher wurden dann in regelmäßigen Abständen im Bazaar Erste-Hilfe-Stationen aufgebaut. Am Morgen des 10. Tages hörte man in der Stadt überall die über Lautsprecher übertragenen Gebete, während sich bis gegen Mittag immer mehr Menschen im Bazaar einfanden und auf den Beginn der Prozession warteten. Unter den wartenden Zuschauern befanden 
sich auch einige wenige Touristen. Die Prozession zog sich von einem Sammelplatz am nördlichen Stadtrand Lehs langsam bis zum Shi'a Matam Serai in der Mitte des Main Bazaar.

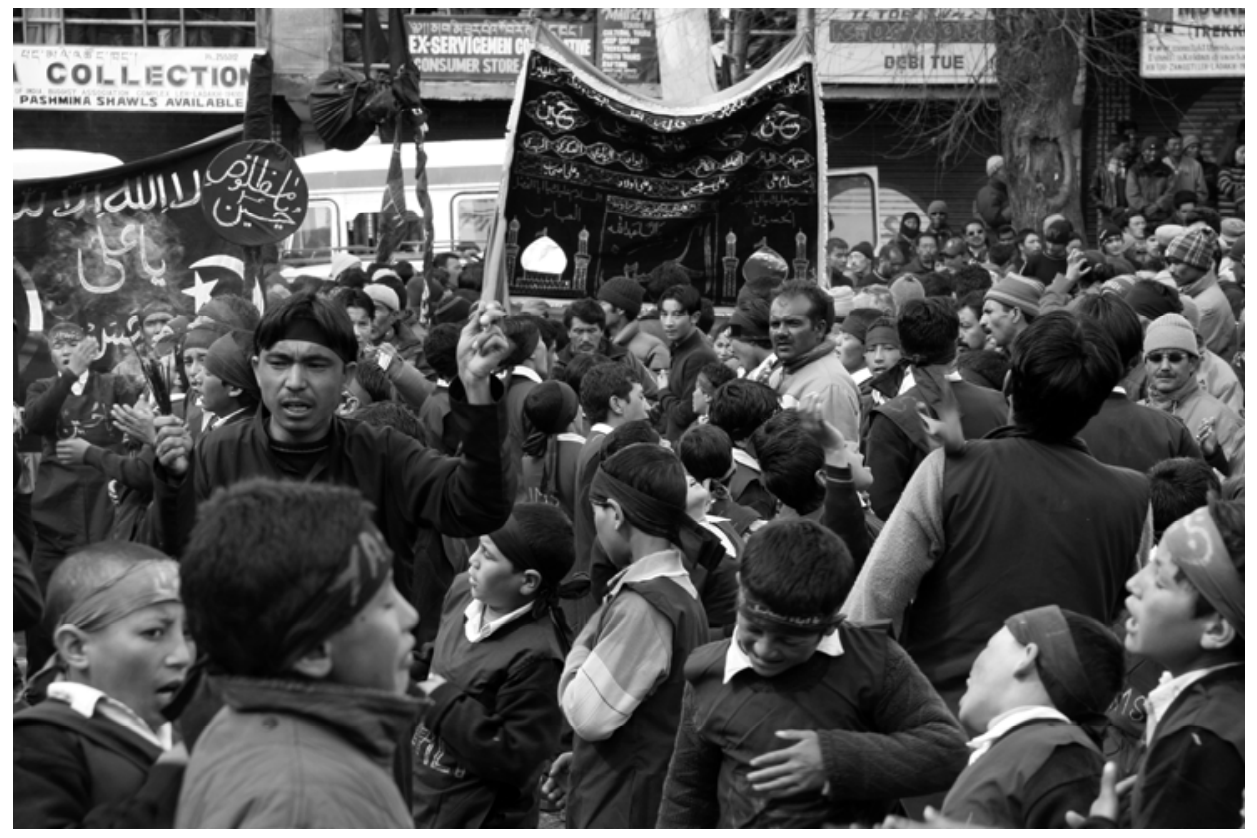

Abb. 4: Schüler der Imamia Mission School während der Zuljenab-Prozession im Main Bazaar von Leh. Angeleitet von ibren Lehrern schlagen sich die Jungen im Rhythmus der Korangesänge mit der flachen Hand auf die Brust. (Foto AW, 20.02.2005)

Die Teilnehmer der Prozession waren nach ihrer Zugehörigkeit zu verschiedenen Islamschulen und Gemeinden in Gruppen unterteilt, angeführt von den Jungen der Imamia Mission School (s. Abb. 4). Den Kern der einzelnen Gruppen bildeten die sich selbst geißelnden jungen Männer (s. Abb. 5), die umringt waren von anderen Teilnehmern, die sich auf das Schlagen mit der Faust beschränkten. Die Aktivitäten der Teilnehmer wurden geleitet durch rhythmische, über Lautsprecher verstärkte Korangesänge, die sich in regelmäßigen Abständen in Geschwindigkeit und Heftigkeit steigerten. Einer der Höhepunkte war, als der Imam das Martyrium Hussains schilderte, wobei alle Teilnehmer in die Hocke gingen und mit gesenktem Kopf verhartten, wobei das Blut auf den Boden tropfte. 


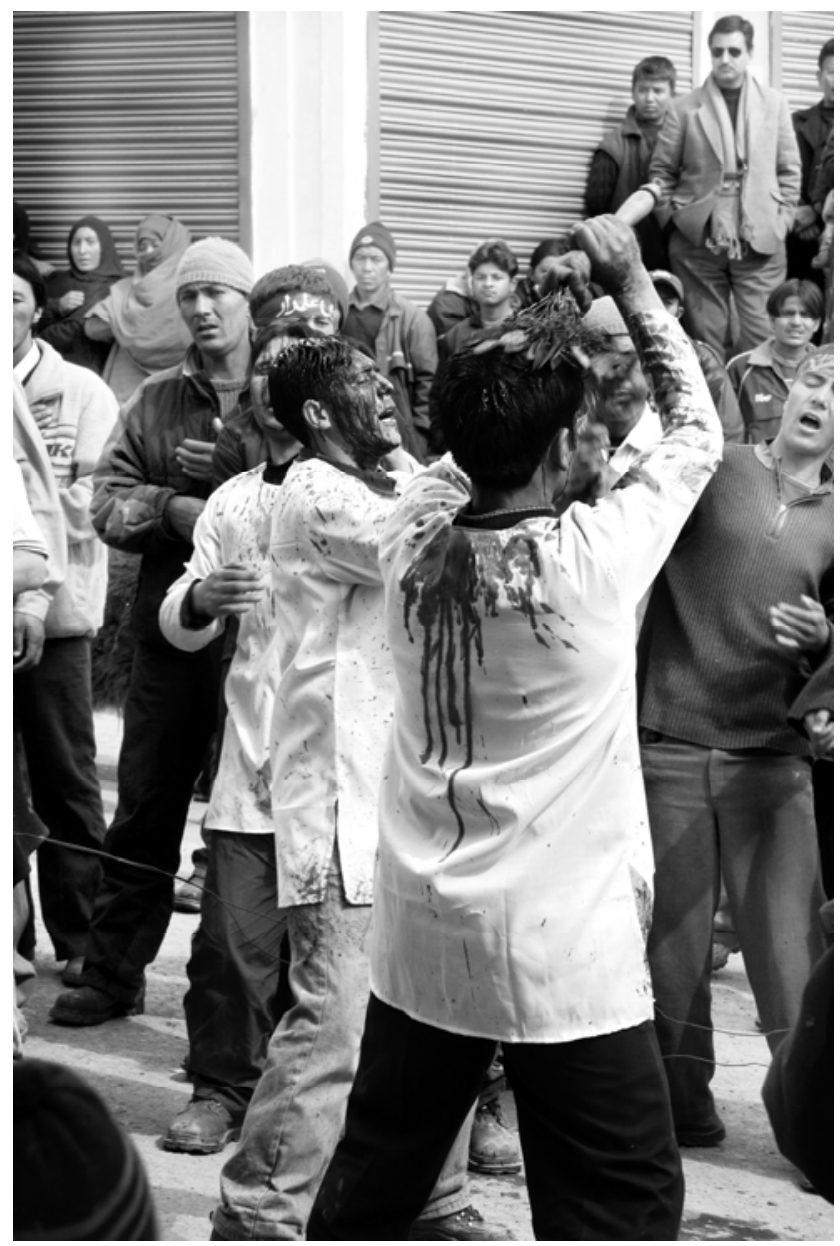

Abb. 5: Junge Shiiten geißeln sich, während der Imam die Geschichte der Schlacht von Kerbala erzählt. Die scharfkantigen Eisenklingen zerschneiden die Kopfhaut, das Blut tropft auf die weißen Überhemden. Ihre Freunde stehen zur Hilfe bereit, falls einer von ibnen zusammenbricht oder sich in Trance eine ernstbafte Verletzung zufügt. (Foto AW, 20.02.2005)

Ein ladakhischer Journalist beschrieb diese Feierlichkeiten im Daily Excelsior. Jammu (Jammu \& Kashmir), einer regionalen Tageszeitung, vor einigen Jahren so:

"The market place in Leh city today resounded with the beatings of chests and jangles of sharp-edged iron chains to mark the expression of grief over the death of Imam Hussain in the hands of Yazeed (a Muslim tyrant) at Karbala 
dessert long ago. 'Ashura' the 10th day of Muhharam procession to commemorate that incident is a significant event in both Kargil and Leh districts". ${ }^{62}$

Deutlich anders haben westliche Ladakhbesucher das Geschehen wahrgenommen, auch gehen sie ganz anders mit dem Erlebten um. Als Beispiel möchte ich einen kleinen Ausschnitt aus einem Gespräch heranziehen. Dieses Gespräch zwischen zwei Touristinnen und dem Guesthouse-Betreiber fand in der Küche des Guesthouses während der Essenzubereitung statt, und zwar unmittelbar nachdem die Beteiligten unabhängig voneinander vom Bazaar zurückgekommen waren. Die (übrigens schwangere) Sprecherin ist noch ganz im Gesehenen gefangen und in dem Wunsch ihre Erlebnisse im Erzählen zu bearbeiten:

„ich bin dran gewöhnt viel Blut zu sehen (.) ich arbeite im Krankenhaus also [unverständlich] aber kleine Kinder (.) so klein (.) die machen so und so (.) und ihre Gesichter als (.) sie wissen nicht, was sie tun (.) ich finde das erschreckend (.) deshalb (.) das finde ich am Schlimmsten (.) und dann der Lärm [...]

uah (.) sie haben dieses kleine Ding in der Hand und machen so und dann $[\ldots]$ ah (.) und da war wie so ein Loch ziemlich tief [...] und man muss sie stoppen (.) man muss wirklich (.) uah (.) das Schlimmste war auf dem Heimweg und dann riechst du das Blut wie (.) uah sie sie äh sprengen Wasser, um das Blut (.) und du gehst zurück und du denkst uah so (.) und es riecht wie im Operationssaal ((lacht)) [...]

mein Mann hat gesagt, lass uns gehen [...] nicht gut für das Baby (.) bad karma ((lacht)) ihr seht ihn nachher er ist noch dort ((lacht)) (10s)

ich bin (.) irgendwie ist es eine Enttäuschung (.) du kommst nach Ladakh und denkst (..) du hast dieses Bild von Ladakh als buddhistisch (.) äh äh alles schön (.) ganz ruhig und dann siehst du so was (.) und dann siehst du so was (lacht)) (---) wir gehen nachher zur Stupa rauf (.) um ein wenig Frieden zu finden $((\text { lacht }))^{\text {c }}$

Ich möchte anhand dieses kleinen Gesprächsausschnitts versuchen zu zeigen, wie stark das Erleben mit den erwähnten Kernthemen verwoben ist und wie die Konstruktion Ladakhs als buddhistisch durch dieses als emotional stark belastend erlebte Ereignis einerseits gefährdet ist, andererseits auf - wie mir scheint - spezifische Weise das Konstrukt auch stützt.

Zwar werden durch den Vergleich mit der eigenen bekannten Alltagspraxis (der Tätigkeit im Krankenhaus) bestimmte zuvor als widerlich (uah) geschilderte Aspekte (nämlich Blut und Geruch) entschärft, doch das erlebte Ritual nimmt - in doppeltem Sinne - mit durch den Lärm und erschreckt sowohl durch die Verletzungen selbst, die sich die Teilnehmer zufügen als auch dadurch, dass sie nicht von alleine aufhören (können).

${ }^{62}$ Morup, Tashi: Muharram procession in Leh, in: Daily Excelsior, Jammu (Jammu \& Kashmir) India, Saturday, April 7, 2001, http://www.dailyexcelsior.com/01 apr07/state.htm\#9 (Zugriff: 21.09.2010) 
Erschreckend ist hier neben der Emotionalität des Geschehens der Kontrollverlust, insbesondere aber auch die Tatsache, dass „,kleine Kinder“ in das Geschehen eingebunden sind, die „nicht wissen, was sie tun“.

Im Anblick der Zuljenah-Prozession verbindet sich so die westlichrationalistische Kritik an der unsteuerbaren Emotionalität und dem Kontrollverlust mit der unmittelbaren Angst vor Ausschreitungen und Gefährdung der eigenen Person. Angesichts zunehmenden islamistischen Terrors in der Welt und der (vermeintlichen) Indoktrination und Aufwiegelung kleiner Kinder scheint der Schritt von blutigen Selbstgeißelungen im Rahmen der Zuljenah-Prozession bis zu Selbstmordanschlägen nur klein zu sein.

Auf die eigene Schwangerschaft verweisend, sagt die Sprecherin, noch mal zu der Prozession zurückzugehen sei nicht gut für das (ungeborene) Baby. In der Sequenz verbinden sich so über die unwissenden kleinen Kinder, die nicht zu stoppenden jungen Männer und das ungeborene eigene Baby, die als schrecklich erlebte Gegenwart und die gefährdete Zukunft. Aber während sie mit den blutüberströmten jungen Männern die Zukunft der „kleinen Kinder“ bereits vor Augen hat, lässt sich der negative Einfluss des Erlebten, das „schlechte Karma“ noch ausgleichen - durch Vermeiden weiterer ähnlicher Erlebnisse einerseits, ausgleichende Handlungen wie den Gang zur Stupa andererseits. Aber neben dem Verweis auf die hinduistisch-buddhistische Vokabel „bad karma“ und den geplanten Gang zur Stupa, ist auch allein schon die Tatsache bedeutsam, dass dieses Gespräch im vertrauten, buddhistischen (also „schönen“ und „ruhigen“) Guesthouse stattfindet.

Während die beiden Äußerungen (bad karma und Gang zur Stupa) einerseits durch ihren Zitatcharakter dem nötigen Abbau emotionaler Spannung dienen und in Lachen kulminieren, verweisen sie andererseits auf eine als ,buddhistisch ${ }^{6}$ verstandene und als solche für erstrebenswert erachtete Praxis, derentwegen man nach Ladakh gekommen ist. Mit einer unerwarteten, als nicht passend, als erschreckend und schrecklich empfundenen Praxis konfrontiert zu werden, führt also nicht nur zu emotionalem Ungleichgewicht, sondern auch zur Enttäuschung des mitgebrachten Bildes von Ladakh, der durch ausgleichende Handlung begegnet wird: dem Rückzug ins buddhistische Guesthouse und dem Gang zur (schönen, friedlichen) Stupa.

Soweit zum skizzierten Beispiel. Da der Aspekt der Emotionalität im Weiteren eine Rolle spielt, möchte ich dessen Bedeutung im Zusammenhang mit der Zuljenah-Prozession jedoch durch zwei Hinweise untermauern.

Mit Pinault (2001) sei auf die Debatte verwiesen, die innerhalb der shiitischen Gemeinden um die blutigen Selbstgeißelungen geführt werden. Einerseits werden diese auch von shiitischen Kritikern aufgrund der ungezügelten Emotionalität als eigentlich unislamisch kritisiert. Andererseits wird aber explizit auf den Eindruck verwiesen, den dieses Ritual bei anderen, v.a. auch im Westen, hervorruft. Diese Debatte wird auch im Iran geführt, wobei Kritiker der Selbstgeißelung dort durch diese Argumentation explizit auf westliche Befürchtungen hinsichtlich islamisti- 
schen Terrors verweisen, während es in Ladakh eher um die Selbstrepräsentation gegenüber Sunniten und Buddhisten geht.

Für Personen mit christlichem Glauben hingegen stellt sich die ZuljenahProzession womöglich als „satanische“ Praxis dar, wobei der Amerikaner Keith Koepsel (2003) sich mit diesem Ausdruck in seinem Weblog63 auf den „beunruhigenden“ Charakter und die „exzessive Gewalt" der Selbstgeißelung bezieht, die er 2001 in Leh beobachtet hat.

An Koepsels Beschreibung interessiert mich insbesondere, dass er sein Erleben der Zuljenah-Prozession mit dem Erleben des Matho-Festivals vergleicht, wobei er beide Rituale als „satanic“, und letzteres als „basically fake“ bezeichnet. Die vermeintlich übermenschlichen Fähigkeiten der Orakel seien nur fingiert gewesen, denn - ich zitiere aus einer E-Mail, mit der er 2005 auf eine Nachfrage meinerseits antwortete -

„sie gaben den zwei Orakeln ein Halluzinogen, und dann taten diese all die Sachen, die du kennst. Aber das Schwert, mit dem sie sich schnitten, war sehr stumpf. Und sie wurden von anderen Mönchen geführt und nicht von den Dämonen, von denen sie angeblich besessen waren." (Koepsel 2005, eigene Übersetzung) ${ }^{64}$

Ähnlich kritische Aussagen hört man auch von anderen Besuchern des MathoFestes. Und da sie sich nicht mit den vorhin herausgearbeiteten Repräsentationen des Festes - exotisch, berühmt, besonders, authentisch - decken, möchte ich sie zum Anlass nehmen, etwas ausführlicher darauf einzugehen, wie das Matho-Fest und auch andere Klosterfeste vor Ort erlebt werden.

Die in den genannten Kernthemen zum Ausdruck gebrachten Erwartungen werden im Alltag von Ladakhtouristen nämlich nicht nur durch allenthalben sichtund hörbare Aspekte der Modernisierung und die Existenz des Islam und islamischer Alltagspraxis enttäuscht. Auch im Zusammenhang mit gerade als authentisch empfundenen bzw. erwarteten buddhistischen Praktiken lauert die Enttäuschung.

Die Attraktion des Klosterfestes Matho Nagrang leitet sich aus den Kernthemen ab, mit denen Ladakh insgesamt repräsentiert ist, ergänzt allerdings durch das Mysterium der Orakel (übermenschliche Fähigkeiten, Weissagungen) und die Exklusivität des Ereignisses. Matho Nagrang ist berühmt und wird von vielen Ladakhis besucht, die lange Wege auf sich nehmen. Da es im Winter stattfindet, wird es jedoch von nur wenigen ausländischen Besuchern gesehen. Beide Aspekte unterstützen das Kernthema ,Authentizität', befeuern aber auch das damit verbundene Kernthema Exotik und versprechen, den Wunsch nach Abenteuer und Exklusivität zu befriedigen.

\footnotetext{
63 Der Eintrag vom 15. März 2003 (Titel: A Disturbing Procession) ist Teil des Berichts über Keith Koepsels 6-monatigen Aufenthalt in Ladakh, wo er sein Sabbatical als Musiklehrer verbracht hat. Online verfügbar unter: http://www.oktrails.com/India/disturbing.htm (Zugriff: 22.10.2008).

${ }^{64}$ In dieser E-Mail bekräftigt er auch noch einmal das „Satanische“ der beschriebenen schiitischen allerdings auch der buddhistischen Praxis und verweist auf die „Unmöglichkeit“, auf diese Weise „das Paradies zu erlangen."
} 
Was die Orakel angeht, so haben wir bereits gesehen, dass diese keineswegs mit übermenschlichen Kräften begabt erschienen. Und selbst die Trance war in Keith Koepsels Augen durch ein Halluzinogen statt durch einen Dämon verursacht, was beides die wahrgenommene Authentizität des Spektakels deutlich einschränkt. Doch wie sieht es mit den anderen Teilen des Festes, zum Beispiel den ChamTänzen aus? Ganz ohne Frage erfüllen diese die Sehnsucht nach exotischen Gewändern und Masken, wobei die Masken genau wie die komplizierte Choreographie der Cham-Tänze geheimnisvoll und unverständlich bleiben, wenn man sich nicht bereits intensiv mit buddhistischer Lehre, vajrayanischer Symbolik und tantrischen Meditationstechniken auseinandergesetzt hat. Die meisten Touristen haben dies nicht getan und finden sich relativ hilflos einer Praxis gegenüber, deren Sinnhaftigkeit sich ihnen schlicht nicht erschließt und die ihnen noch dazu vor Ort niemand so recht erklären kann. Was man jedoch auch als relativ unbedarfter Zuschauer erkennen kann, ist, dass es sich bei den Tänzen um eine Aufführung speziell ausgebildeter Spezialisten handelt, nämlich Lamas, die lange geübt haben, und dass diese Aufführungen in einem abgegrenzten Raum stattfinden, nämlich im Klosterhof. Dieser Hof ist für die Cham-Tänzer reserviert und wird von Aufpassern mit Stock von Zuschauern freigehalten, wenn er nicht wie z.B. bei den Festen in Hemis und Phyang mit einem Seil abgesperrt ist. Aufgrund der großen Besucherzahlen kommt es zwischen den Zuschauern zu Konkurrenz und Gedränge um den besten Platz. Die Tänze selbst sind durchchoreographiert, es gibt - außer bei den ,Clowns ${ }^{6}$ - keine Improvisation, jede Bewegung ist bedeutsam, keine zufällig. Der Inhalt der Tänze verweist auf abstrakte Sinnzusammenhänge, emotionale Zustände werden abstrahiert und als Projektionen dargestellt. Die Musik (insbesondere die Hörner) sowie das sonore Singen der Mantras wirken zwar meditativ und tendenziell trance-induzierend - durch die als unharmonisch und z.T. kakophonisch empfundenen Surnas, vor allem aber durch die anderen äußeren Umstände (es herrscht Gedränge, es ist eng, kalt/heiß, staubig, langsam) wird die Situation insgesamt jedoch von den meisten auch als anstrengend und langweilig empfunden.

Da der inhaltliche Bezug fehlt, kommt es schnell zur Beschäftigung mit dem Ritualgeschehen eigentlich völlig äußeren Dingen, wie

1. der Begutachtung der Güte der Darbietung (fake, schlecht getanzt, unordentlich, unkonzentriert),

2. dem Ärger über Tourgruppen, die VIP-Plätze bekommen, weil sie Geld an das Kloster zahlen,

3. dem Ärger über Touristen, die drängeln, weil sie fotografieren wollen, und dabei keine Rücksicht auf andere Touristen und Einheimische nehmen,

4. dem Ärger über die Einheimischen, die einem die Sicht versperren oder drängeln - schließlich hat man selbst „,viel Geld für den Besuch bezahlt und die können ja jedes Jahr kommen", 
5. aus demselben Grund dem Ärger über den Reiseveranstalter oder das Kloster, weil das Geschehen nicht ausreichend erläutert wird und die Infrastruktur schlecht ist (keine Toiletten, zu wenig Stühle, zu viel Staub etc.),

6. der Frage, ob man die, richtigen' Fotos hinbekommen hat,

7. dem Austausch von Reiseerlebnissen etc.

So müssen die Besucher feststellen, dass das Klosterfest, dessentwegen sie vielleicht extra nach Ladakh gereist sind, sie emotional kalt lässt und ihnen unverständlich bleibt, während es gleichzeitig auch andere Bedürfnisse nur zum Teil erfüllt und Enttäuschung produziert.

Hier kommen wieder die Schlüsselkategorien Authentizität, Besonderheit, bessere Welt ins Spiel. Erwartet, aber enttäuscht durch die „Kommerzialisierung“ der Klosterfeste, die doch recht vielen anderen Touristen, die Ungleichbehandlung der Zuschauer (auch durch die Lamas) und die Modernisierung (Lautsprecher, Videoproduktion durch Einheimische), entsteht eine starke Spannung zwischen dem mitgebrachten Bild von Ladakh und dem tatsächlich Erlebten. Auch in diesem Fall führt die Dissonanz zwischen Erwartung und Erfahrung wieder zu spezifischen Strategien. Einerseits entlädt sie sich bereits vor Ort in z.T. lautstarkem Ärger. Sie produziert aber auch den Effekt, dass vor Ort nicht - wie man eigentlich vielleicht erwarten würde - das fremd bleibende Ritualgeschehen narrativ verarbeitet wird, sondern die diesem eigentlich äußerlichen Geschehnisse, die eben nicht kalt lassen, sondern die Gemüter erhitzen. Fokus der Erzählungen vor Ort sind dann die anderen Touristen, die sich in irgendeiner Weise falsch benommen haben, oder wie der eine Mönch immer fast gestolpert ist. Und fast immer endet das Gespräch im Lamentieren darüber, dass Ladakh durch die Modernisierung und den Tourismus zerstört werde und seine traditionelle authentische Kultur verliere. ,Hörensagen'Geschichten füllen das als erwartungskonträr unspektakulär empfundene Ereignis auf. Ein Beispiel wäre der folgende Satz aus dem Prospekt von Exodus-Travels $(2010)^{65}$ :

„They have been known to sprint along the thin outer walls of the gompa and over roofs without falling, and have been seen to cut their mouths and tongues with knives and swords; the next morning there are no scars to be found..."

Mit diesem Narrativ, das ähnlich auch in vielen Reiseführern und in den Berichten von Touristen zu finden ist, wird gleichzeitig das erwartete (und zu erwartende) Mystische dargestellt wie auch darauf verwiesen, dass es sich um etwas Wunderbares, nicht rational zu Erklärendes handelt, das nicht jeder zu Gesicht bekommt. Dieses zuletzt genannte Element verstärkt sich noch durch andere ,Hörensagen'-Geschichten, denen zufolge die Orakel gar nicht fotografiert werden könnten. Entweder habe es bei dem Versuch, dies doch zu tun, hinterher leere Filme gegeben, oder die Orakel hätten die Fotografen über die hohen Mauern und Dächer gejagt, wobei mindestens einmal ein Tourist abgestürzt sei.

65 Trip Notes: AIF "Leh to Amritsar" 2010. Online unter: www.exodus.co.uk/assets/pdf/ tripnotes/2010/aif.pdf (Zugriff: 21.09.2010) 
Damit verweisen diese Narrative sowohl auf Abenteuer und Gefahr, Geheimnis und Unerklärlichkeit, als auch auf die Notwendigkeit, dieses Ereignis selbst erleben zu müssen. Sie unterstreichen den spektakulären und exzeptionellen Charakter der eigenen Erlebnisse, die vor Ort eher als enttäuschend empfunden worden waren und retten den Ladakhbesucher vor der bitteren Erkenntnis, falschen Erwartungen aufgesessen zu sein. So erfüllen diese Narrationen dieselbe Funktion wie auch viele der von Touristen gemachten Fotos. Denn durch die implizite Gleichsetzung von Ladakh mit Buddhismus, Authentizität, Abgeschiedenheit und Exklusivität usw. scheinen die enttäuschten Besucher geradezu dazu gezwungen, durch stereotype Fotos (wie im Reiseführer oder Bildband) die nicht erlebte Authentizität und Unberührtheit des ,wahren' Ladakh wieder herzustellen - nicht nur für andere, als Beweis, selbst da gewesen, Entdecker zu sein, sondern vor allem auch für sich selbst, zur Befriedigung der Sehnsucht nach dem Shangri-La.

So lässt sich der beträchtliche Eigensinn im Festhalten an Erwartungen und Ansprüchen erklären, der zur Bewältigung der Erwartungs-Erfahrungs-Lücke und daraus resultierenden kognitiven Dissonanz jedoch in zunehmend größerem Ausmaß bestimmter narrativer und imago-generierender Strategien bedarf, die gleichsam versöhnende Semioseprozesse hervorbringen und den Diskurs zumindest in der Schwebe halten.

\section{Postskriptum}

Auf Basis des Gesagten möchte ich abschließend eine Überlegung äußern, die im Zusammenhang mit der Erforschung interkultureller Kommunikation und Kompetenz Ansatz für weiter reichende Schlüsse sein könnte.

Ohne hier auf die Einzelheiten noch einmal einzugehen, möchte ich das Erleben der beiden geschilderten Ereignisse als ,heiß ${ }^{\star}$ bzw. ,kalt ${ }^{\star}$ einander gegenüber stellen. Das Erleben der shiitischen Aschura-Prozession möchte ich als ,heiß` bezeichnen. Sie übt auf die westlichen Touristen keine positive Attraktion aus, involviert sie jedoch emotional und ist dadurch nicht langweilig. Sie wird als archaisch, gefährlich und abstoßend erlebt und als unzivilisiert oder gar anti-zivilisatorisch empfunden. In dem Maße wie sie emotional gerade nicht unverständlich ist, sondern eigene archaische Impulse anrührt, und gleichzeitig als die eigene Person oder Weltanschauung bedrohende Praxis wahrgenommen wird, führt sie $\mathrm{zu}$ heftigen Reaktionen und Ablehnung. ${ }^{66}$ Das Erleben der buddhistischen Klosterfeste hingegen möchte ich als ,kalt bezeichnen. Sie üben zwar in der Erwartung eine große Attraktion aus, lassen die Zuschauer dann aber emotional unbeteiligt und werden als abstrakt, hermetisch und langweilig erlebt. Sie bleiben tatsächlich fremd.

\footnotetext{
${ }^{66}$ Dass die Zuljenah-Prozession von westlichen Touristen als ,unverständlich` und ,fremd` bezeichnet wird, würde man in psychoanalytischer Terminologie als Abwehrmechanismus bezeichnen. Die wahrgenommene Bedrohung stammt gerade nicht nur von ,außen', sondern rührt auch aus den eigenen archaischen aggressiven Impulsen und anderen starken Emotionen her, die im Zivilisationsprozess zu zähmen und im Zaum zu halten sind.
} 
Die hier aus dem Widerspruch zwischen Erwartung und Erfahrung entstehende kognitive Dissonanz führt dazu, dass das als erwartungskonträr unspektakulär empfundene Ereignis durch Hörensagen-Geschichten aufgefüllt wird. Hierbei handelt es sich um Narrationen, die in Form kolportierter Fremderlebnisse in erster Linie bekannte Stereotype wiederholen, die erwartungskonform sind. Insofern verweisen diese Narrative in der Regel auf Abenteuer und Gefahr, Geheimnis und Unerklärlichkeit. Dadurch, dass es sich um Fremderlebnisse handelt, lassen sie sich einerseits nicht direkt überprüfen, andererseits ermöglichen sie dem Erzähler aber, sich selbst noch in der Distanzierung vom Inhalt der Anekdote auf andere Erzähler zu berufen, und so von ihrer vermeintlichen Gültigkeit zu profitieren. Sie stellen damit den erwarteten spektakulären und exzeptionellen Charakter der eigenen Erlebnisse erst her, der vor Ort gar nicht gegeben war.

Gerade im Zusammenhang mit ,kalten' Ereignissen scheint es durch Berufung auf Stereotype somit nicht nur möglich zu sein, kognitive Dissonanz abzuschwächen, sondern gleichzeitig auch nach außen ein kohärentes Bild von sich selbst wie auch den, eigenen' Erlebnissen zu produzieren, statt aufgrund dissonanter Erlebnisse eigene Erwartungen zu hinterfragen, also durch Differenzerfahrung zu lernen. Anders sieht dies bei ,heißen', emotional involvierenden Ereignissen aus. Wie schon gesagt, führen diese unter Umständen zu heftiger Ablehnung, wobei jedoch zu beachten ist, dass es sich nicht notwendigerweise tatsächlich um äußere Gefahren handeln muss, die zu der Abwehr führen. Es kann sich z.B. auch um Verdrängungsprozesse, Projektionen oder andere psychische Abwehrmechanismen handeln. Im Zusammenhang mit der Fähigkeit zur Selbstreflexion sensu Devereux (1992) und der Bereitschaft zur Selbstveränderung könnte so gerade die emotionale Involviertheit zu Fremdverstehen führen und damit interkulturelles Lernen ermöglichen. Dies dürfte insbesondere dann der Fall sein, wenn die Situation im Weiteren keinen einfachen Ausweg erlaubt und (Selbst-)Veränderung gleichsam erzwingt, sodass aus einer Situation mit Lernangebot hinsichtlich kultureller Differenz ein Lernproblem im Sinne Holzkamps (1995) entsteht.

\section{Literatur}

Alheit, Peter (2005): Neugier, Beobachtung, Praxis - Forschendes Lernen als Methode erziehungswissenschaftlichen Studierens, -in: Thon, Christine/Rothe, Daniela/Mecheril, Paul/Dausien, Bettina: Qualitative Forschungsmethoden im erziehungswissenschaftlichen Studium, Universität Bielefeld, http://bieson.ub.unibielefeld.de/volltexte/2006/810/html/Alheit.pdf. Letzter Zugriff: 22.10.2008.

Anscombe, Gertrude E. M.: Intention, Oxford: Basil Blackwell 1985

Appelsmeyer, Heide/Kochinka, Alexander/Straub, Jürgen: Qualitative Methoden, -in: Straub, Jürgen/Kempf, Wilhelm/Werbik, Hans (Hrsg.): Psychologie - Eine 
Einführung. Grundlagen, Methoden, Perspektiven, München: Deutscher Taschenbuch Verlag 1997, S.709-742

Bertelsen, Kristoffer Brix: Our Communalised Future. Sustainable Development, Social Identification and Politics of Representation in Ladakh, Aarhus: Aarhus University (Dissertation), 1996

Bertram, Jutta: "Arm, aber glücklich ...": Wahrnehmungsmuster im Ferntourismus und ibr Beitrag zum (Miss-)Verstehen der Fremde(n), Münster [u.a.]: Lit 1995 (Reihe Fremde Nähe. Beiträge zur interkulturellen Diskussion, Bd. 6)

Bishop, Peter: The myth of Shangri-La: Tibet, travel writing, and the western creation of sacred landscape, Berkeley: University of California Press 1989

Boesch, Ernst E.: Kultur und Handlung. Einführung in die Kulturpsychologie, Bern: Huber 1980

Boesch, Ernst E.: Sehnsucht: von der Suche nach Glück und Sinn, Bern: Hans Huber 1998

Boesch, Ernst E.: Symbolic action theory and cultural psychology, Berlin-New York: Springer 1991

Boesch, Ernst E.: Von Kunst bis Terror. Über den Zwiespalt der Kultur, Göttingen: Vandenhoeck \& Ruprecht 2005

Bora, Nirmala: Ladakh. Society and economy, New Delhi: Anamika 2004

Bruner, Jerome: Acts of Meaning. Cambridge/Mass.-London: Harvard University Press 1990

Devereux, Georges: Angst und Methode in den Verhaltenswissenschaften, Frankfurt/M: Suhrkamp 1992

Dixit, Kanak Mani: Tourism trends and issues across the Himalaya, -in: Luger, Kurt/Inmann, Karin (Hrsg.): Verreiste Berge. Kultur und Tourismus im Hochgebirge, Innsbruck: Studienverlag 1995, S.203-222

Exodus-Travels (2005): Trip Notes: AIZ “Winter in Ladakb”, issued: Apr. 2005, http:/ / www.4real.co.uk/trips/print_template.asp?TripRef=EX-AIZ (Zugriff: 27.05.2005)

Fischer, Hans: Warum Samoa? Touristen und Tourismus in der Südsee, Berlin: Dietrich Reimer 1984

Frembgen, Jürgen W.: Hunza und Shangri-la. Ein Bergvolk in der Touristenwerbung, -in: Münchner Beiträge zur Völkerkunde 2, 1989, S.51-68

Gillespie, Alex (2004a): Returning Surplus: Constructing the architecture of intersubjectivity, Cambridge: University of Cambridge Dissertation 2004 
Gillespie, Alex (2004b): Symbolic adaptation to uncertainty: tourists buying souvenirs in Ladakh, North India, Paper presented at ISSBD 18th biennial conference, Gent/Belgium, 15th July 2004

Gillespie, Alex (2006a): The future and the other: Striving tourists in Ladakh, 4th International Conference on the Dialogical Self, 2006

Gillespie, Alex (2006b): The Striving Tourist In Ladakh, North India, -in: Simão, Livia Mathias/Valsiner, Jaan: Otherness in Question: Labyrinths of the Self, Charlotte/N.C.: Information Age Publishing 2006, S.163-186

Gillespie, Alex (2006c): Tourist Photography and the Reverse Gaze, -in: Ethos, 34, (3), 2006, S.343-366

Gillespie, Alex (2007): Collapsing Self/Other positions: Identification through differentiation, -in: British Journal of Social Psychology, 2007, S.1-7

Glaser, Barney G. \& Strauss, Anselm L.: The discovery of grounded theory: strategies for qualitative research. Chicago: Aldine 1967

Glaser, Barney G. \& Strauss, Anselm L.: Grounded Theory. Strategien qualitativer Forschung, Bern [u.a.]: Hans Huber 1998

Grist, Nicola: Muslims in Western Ladakh, -in: The Tibet Journal, Vol. 20-3, 1995, S.59-70

Hennig, Christoph: Reiselust. Touristen, Tourismus und Urlaubskultur, Frankfurt/M: Suhrkamp 1999

Hilton, James (1933): Lost Horizon, Delhi: Book Faith India 1998

Holzkamp, Klaus: Lernen. Subjektwissenschaftliche Grundlegung, Frankfurt/M: Campus 1995

Hutt, Michael: Looking for Shangri-la: from Hilton to Lamichhane, -in: Tom Selwyn: The Tourist Image. Myths and Myth-making in Tourism, Chichester [u.a.]: John Wiley \& Sons 1996, S.49-60

Jina, Prem Singh: Ladakh. The Land \& the People, New Delhi: Indus Publishing Company 1996

Jina, Prem Singh (Ed.): Ladakh. Past \& Present, New Delhi: Gyan Publishing House 2000

Joas, Hans: Symbolischer Interaktionismus. Von der Philosophie des Pragmatismus zu einer soziologischen Forschungstradition, -in: Kölner Zeitschrift für Soziologie und Sozialpsychologie, 40, 1988, S.417-446

Kagelmann, H. Jürgen: Touristische Medien, -in: Hahn, Heinz/Kagelmann, H. Jürgen (Hrsg.): Tourismuspsychologie und Tourismussoziologie: ein Handbuch zur Tourismuswissenschaft, München: Quintessenz 1993, S.469-479 
Kaul, Shridhar/Kaul, H. N.: Ladakh through the Ages. Towards a New Identity, New Delhi: Indus Publishing Company 1995

Koepsel, Keith (2003): A Disturbing Procession, Oklahoma Outdoor Info. Keith in India, Posted: March 15, 2003 5:43 AM, http://www.oktrails.com/India/disturbing.htm (Zugriff: 22.10.2008)

Kortländer, Kristina: Das Land des Lächelns. Thailand als Mythos in Reisekatalogen, Münster-Hamburg-London: Lit 2000

Layes, Gabriel: Grundformen des Fremderlebens: Eine Analyse von Handlungsorientierungen in der interkulturellen Interaktion, Münster: Waxmann 2000

Lehner, Erich/Riegel-Jandl, Andrea: Himalayan Future. Land - Mensch - Architektur, Wien: Institut für Baukunst, Bauaufnahmen und Architekturtheorie 2003, http:/ / baugeschichte.tuwien.ac.at/ladakh/index.html (Zugriff 22.10.2008).

Löfgren, Orvar: On Holiday. A bistory of vacationing, Berkeley-Los Angeles-London: University of California Press 1999

Loenhoff, Jens: Medien, -in: Straub, Jürgen/Weidemann, Arne/Weidemann, Doris (Hrsg.): Handbuch Interkulturelle Kommunikation und Kompetenz, Stuttgart-Weimar: Metzler 2007, S.534-543

Luger, Kurt: Kulturen im Veränderungsstreß. Kulturtheoretische Überlegungen zur Tourismusdebatte, -in: Luger, Kurt/Inmann, Karin (Hrsg.): Verreiste Berge. Kultur und Tourismus im Hochgebirge, Innsbruck: Studienverlag 1995, S.19-42

Lüsebrink, Hans-Jürgen: Interkulturelle Kommunikation, Stuttgart: Metzler 2005

Lütt, Jürgen: Deutschland, Indien und das deutsche Indienbild. Das romantische und das utilitaristische Indienbild Europas, -in: Landeszentrale für politische Bildung, Baden Württemberg, Der Bürger im Staat. Indien, 48.Jg., H.1, Stuttgart: Landeszentrale für politische Bildung, Baden Württemberg 1998, S. 60-64

MacCannell, Dean: The Tourist. A New Theory of the Leisure Class, New York: Schocken 1976

Mattausch, Jutta: Ladakh und Zanskar, Bielefeld: Reise Know How Verlag Peter Rump 2000

Mörth, Ingo: Fremdheit, wohldosiert. Tourismus als Kultur der kontrollierten Begegnung mit dem Fremden, -in: Trans, 15, 2004, http://www.inst.at/trans/15Nr/09_1/moerth15.htm (Zugriff: 22.10.2008).

Morup, Tashi (2001): Muharram procession in Leh, -in: Daily Excelsior, Jammu (Jammu \& Kashmir) India, Saturday, April 7, 2001, http://www.dailyexcelsior.com/01apr07/state.htm\#9 (Zugriff: 24.05.2005). 
Opaschowski, Horst W.: Das gekaufte Paradies. Tourismus im 21. Jahrhundert, Hamburg: B.A.T. Freizeit-Forschungsinstitut 2001

Parvaiz, Athar: A Famed Region's Triple Whammy of Environmental Bane, -in: IPS News, 18.11.2009, http://ipsnews.net/news.asp?idnews=49316 (Zugriff 21.09.2010)

Pinault, David: Horse of Karbala. Muslim devotional life in India, New York: Palgrave 2001

Popp, Herbert: Reisen bildet - Klischees bleiben, -in: Forschung Spezial, 2004, S.5659

Schellhorn, Matthias/Perkins, Harvey C.: The stuff of which dreams are made: Representations of the south sea in german-language tourist brochures, -in: Current issues in tourism, 7, (2), 2004, S.95-133

Schmidt, Bernd Oliver: Der Orient - Fantasia 1001 Nacht. Wie Touristen Fremdes sehen und verstehen, Starnberg: Studienkreis für Tourismus und Entwicklung e.V. 2001

Selwyn, Tom (ed.): The Tourist Image. Myths and Myth-making in Tourism, Chichester [u.a.]: John Wiley \& Sons 1996

Stagl, Justin: Eine Geschichte der Neugier - die Kunst des Reisens 1550 -1800, Wien [u.a.]: Böhlau 2002

Straub, Jürgen: Handlung, Interpretation, Kritik - Grundzüge einer textwissenschaftlichen Handlungs- und Kulturpsychologie, Berlin-New York: de Gruyter 1999

Straub, Jürgen: Understanding Cultural Differences: Relational Hermeneutics and Comparative Analysis in Cultural Psychology, -in: Straub, Jürgen/Weidemann, Doris/Kölbl, Carlos/Zielke, Barbara (Hrsg.): Pursuit of Meaning. Advances in Cultural and Cross-Cultural Psychology, Bielefeld: Transcript 2006, S.163-213

Straub, Jürgen/Weidemann, Arne/Weidemann, Doris (Hrsg.): Handbuch Interkulturelle Kommunikation und Kompetenz, Stuttgart-Weimar: Metzler 2007

Straub, Jürgen: Understanding Cultural Differences: Relational Hermeneutics and Comparative Analysis in Cultural Psychology, -in: Straub, Jürgen/Weidemann, Doris/Kölbl, Carlos/Zielke, Barbara (Hrsg.), Pursuit of Meaning. Advances in Cultural and Cross-Cultural Psychology, Bielefeld: Transcript 2006, S.163-213

Straub, Jürgen/Shimada, Shingo: Relationale Hermeneutik im Kontext interkulturellen Verstehens. Probleme universalistischer Begriffsbildung in den Sozial- und Kulturwissenschaften erörtert am Beispiel „Religion“, -in: DZPhil, 47, 3, 1999, Berlin, S.1-29

Strauss, Anselm L./Corbin, Juliet: Basics of qualitative research. Grounded theory procedures and techniques, Newbury Park: Sage 1990 
The American Heritage Dictionary, Third Edition, Version 3.6a., SoftKey International 1994

Van Beek, Martijn: The art of representation. Domesticating Ladakhi 'identity', -in: Marie Lecomte-Tilouine \& Pascale Dollfus (ed.): Ethnic revival and religious turmoil. Identities and representations in the Himalayas, New Delhi: Oxford University Press 2003

Vorlaufer, Karl: Tourismus in Entwicklungsländern. Möglichkeiten und Grenzen einer nachhaltigen Entwicklung durch Fremdenverkehr, Darmstadt: Wissenschaftliche Buchgesellschaft 1996

Ward, Colleen/Bochner, Stephen/Furnham, Adrian: The Psychology of Culture Shock, London: Routledge 2001

Weidemann, Arne: Tourismus, -in: Straub, Jürgen/Weidemann, Arne/Weidemann, Doris (Hrsg.): Handbuch Interkulturelle Kommunikation und Kompeten₹, StuttgartWeimar: Metzler 2007, S.613- 627

Weidemann, Arne: Pragma-semantische Analysen zur Erforschung interkultureller Kommunikation, -in: FQS, Themenschwerpunkt 01/2009: „Qualitative Forschung zur interkulturellen Kommunikation".

Weidemann, Doris: Interkulturelles Lernen. Erfahrungen mit dem chinesischen, Gesicht': Deutsche in Taiwan, Bielefeld: transcript 2004

Weidemann, Doris/Straub, Jürgen: Psychologie interkulturellen Handelns, -in: Straub, Jürgen/Kochinka. Alexander/Werbik, Hans (Hrsg.): Psychologie in der Praxis. Anwendungs- und Berufsfelder einer modernen Wissenschaft, München: Deutscher Taschenbuch Verlag 2000, S.830-855

Weiß, Martin: Studienreisen nach Marokko. Angebote, Teilnehmerkreis, Reisemotive, Images, Passau: L.I.S Verlag 1998 (Maghreb-Studien 9)

Wemhöner, Karin: Paradiese und Sehnsuchtsorte. Studien zur Reiseliteratur des 20. Jahrbunderts, Marburg: Tectum 2004 

Das Kapitel „Zwischen Fremdwahrnehmung und Selbstverortung“ von Maria E. Brunner wurde auf Wunsch der Autorin aus der freien

Online-Version entfernt und steht nur noch in der Print-Ausgabe zur Verfügung.

Universitätsverlag Göttingen

im September 2011 



\title{
Indischer Arbeitsplatz aus deutscher Sicht
}

\author{
Niteen Gupte / Anke Müller-Gupte \\ I
}

Niteen Gupte

Pune, die zweitgrößte Metropole neben Mumbai im indischen Bundestaat Maharashtra, gilt, laut der Zeitschrift WirtschaftsWoche, als die „Hauptstadt der deutschen Unternehmen " in Indien. ${ }^{1}$ In dieser Region sind über 250 Unternehmen mit deutscher Beteiligung angesiedelt, vorwiegend aus der Automobil- und IT- Branche. Es handelt sich hier sowohl um große Produktionsstätten als auch um mittelständische Firmen. 2007 wurde am Department of Foreign Languages an der Universität Pune eine Studie durchgeführt, ${ }^{2}$ um zu sehen, wie die in der Pune-Region angestellten deutschsprachigen Arbeitnehmer ${ }^{3}$ ihren indischen Arbeitsplatz wahrnehmen. Im Folgenden wird diese Studie präsentiert und einige ihrer Aspekte hervorgehoben. Der Schwerpunkt der Recherche lag auf der zwischenmenschlichen Kommunikation und der Wahrnehmung der indischen Arbeitskultur. Was vorwie-

1 WirtschaftsWoche Global, Nr.2, 17.11.2008, [Umschlagseite]

2 Das erste Ergebnis der durch Centre for Social Sciences (CSS) der Universität Pune unterstützten Studie liegt vor unter Gupte, Niteen/Müller-Gupte, Anke: Indischer Arbeitsplatz aus dentscher Sicht. Eine Studie in interkultureller Kommunikation, Pune 2008 (CSS Occasional Papers Series 2007-2008, Univ. of Pune)

${ }^{3}$ Es wird im Folgenden die männliche Bezeichnung benutzt - des Leseflusses wegen und auch weil die Mehrzahl der interviewten Personen männlich ist. 
gend zur Sprache kam, waren die Kommunikationsschwierigkeiten und weitere Spannungsfelder, die den Arbeitsalltag bestimmen. Deutlich wurden dadurch bestimmte Stereotypen, welche die Deutschen ${ }^{4}$ als typisch indisch wahrnehmen, die ihnen in ihrem Arbeitsalltag fremd sind und sie irritieren.

Im Rahmen der Studie wurden zwanzig Intensiv-Interviews mit deutschsprachigen arbeitstätigen Expats durchgeführt; auf eine quantitative Erhebung anhand von Fragebögen wurde verzichtet. Die Interviews wurden aufgezeichnet, transkribiert und die Transkriptionen von 1 bis 20 durchnummeriert; die in den [eckigen] Klammern angegebenen Zahlen im folgenden Text weisen auf diese Transkriptionen hin. ${ }^{5}$ Die Interviews, in der Regel zwei bis vier Stunden lang, orientierten sich zwar an einem Interviewleitfaden; ${ }^{6}$ es wurde jedoch Wert darauf gelegt, die Interviewpartner frei sprechen zu lassen, so dass sie selbst die Gesprächschwerpunkte bestimmten. Ein Datenbogen ${ }^{7}$ erfasste die harten Fakten der interviewten Person und deren Arbeitsplatz; wenn möglich (siehe unten) fand auch eine Besichtung des Arbeitsplatzes statt. Teil III der folgenden Arbeit gibt eine zusammenfassende Beschreibung aller 20 Interviews wieder.

Bis auf wenige Ausnahmen handelt es sich bei den Interviewpartnern um Angestellte bei der Großindustrie. Es darf nicht verschwiegen werden, dass es bei den mittelständischen und kleineren Betrieben ausdrücklich an einer Bereitschaft zur Kooperation mit der Recherche mangelte. Alle in der Region Pune ansässigen Betriebe mit deutscher Beteiligung, deren Adressen uns die Deutsch-indische Wirtschaftskammer (The Indo-German Chamber of Commerce), Mumbai, freundlicherweise zur Verfügung stellte, wurden angeschrieben; keines der mittelständischen Betriebe meldete sich zurück; persönliche Anfragen wurden abgewiesen. So konnte nur ein Interviewter gefunden werden und nur mit dem Versprechen der äußerster Diskretion [3], so dass ein Besuch zu dem Arbeitsplatz unterlassen werden musste. Ein anderer Interviewpartner bildete eine weitere Ausnahme, insofern dass er in einer indischen Firma ohne europäische Kapitalbeteiligung als einziger Europäer tätig ist, was er als ein „,hard core Programm“ ${ }^{\text {* }}$ bezeichnete. Die Vermutung liegt nahe, dass es bei den Firmen nicht erwünscht wäre, dass die gespannten Verhältnisse im Personalwesen gerade im Bezug auf die interkulturelle Kommunikation, die im Interview augenscheinlich würden, öffentlich bekannt werden. Alle Interviewpartner nahmen an dem Projekt engagiert teil und zeigten ein deutliches Interesse an dessen Ergebnis. Zwei Interviewpartner leben freiberuflich und haben sich ihren Arbeitsort aus privaten Gründen gewählt [14, 20]; in manchen Aspekten bilden diese eine Ausnahme, was ihre Beziehung zum indischen Arbeitsleben be-

\footnotetext{
4 Wenn im Weiteren, der besseren Lesbarkeit wegen, von Deutschen und Indern gesprochen wird, so beziehen wir uns damit auf die deutschen InterviewpartnerInnen und die von ihnen so wahrgenommenen indischen MitarbeiterInnen.

53 Transkriptionen in: Gupte/Müller-Gupte (2008), S.204-347

${ }^{6}$ ebd., S.348-362

${ }^{7}$ ebd., S.365-366

8 ebd., S. 207.
} 
trifft. 17 unter den 20 Interviewpartnern sind männlich; 28 bis 65 Jahre alt und haben hier von 6 Monaten bis 18 Jahren gearbeitet.

Ausnahmslos alle Expats sind hoch motiviert, zumindest am Anfang ihres Indienaufenthaltes. Indien und die Arbeit werden angesehen als Herausforderung, eine professionelle sowie persönliche. Die Versetzung nach Indien ist ein Aufstieg auf der Karriereleiter, in einigen Fällen sogar die Beförderung an die höchste Spitze - verbunden mit finanziellen Vorteilen gegenüber der früheren Stelle. In Indien steht den Interviewpartnern in professioneller Hinsicht ein größerer Freiraum zur Verfügung, um eigenständig Ziele verfolgen, Strategien entwickeln und diese verwirklichen zu können. Für einige ist dieser nicht ihr erster Auslandseinsatz, sie bringen Erfahrung mit anderen Kulturen mit und/oder haben vor ihrer Ankunft ein auf Indien bezogenes Interkulturelles Training absolviert. Ob sich dieses als hilfreich erwiesen hat beim Umgang und der Bewältigung des indischen Alltags, bleibt fragwürdig [7, 16]. Ausnahmslos alle haben einen Studienabschluss und sich Wissen über Indien angeeignet. Im Laufe ihres Indienaufenthaltes bemühen sie sich um eine aktive Auseinandersetzung mit dem Land und der Kultur - neben der alltäglichen Alltagserfahrung mittels Büchern, Zeitungen, TV und Reisen, insofern dies ihr hektisches Berufsleben zulässt.

In Indien sehen sie ungeahnte und uneingeschränkte, denn unausgebeutete Möglichkeiten, ihre professionellen und wirtschaftlichen Ziele zu verwirklichen. Die nicht verfestigten und nicht erstarrten Strukturen des Marktes sowie die in Bewegung geratenen Gesellschaftsstrukturen zeugen von einer Vitalität und Flexibilität, die in Deutschland nicht gegeben sind. Ein neuer, ungesättigter Markt öffnet sich ihnen; in bestimmten Branchen ist von paradiesischen Zuständen die Rede: „Dieser große, unerschöpfte Markt, äh, in dem es ja praktisch nichts gab... und was mir unter den Nägeln brennt ist, dass Indien der einfachste Markt für mich ist, in dem ich je gearbeitet habe“, sagt einer aus dem Finanzdienstleistungswesen, ein Anwalt, der seit 20 Jahren in „exotischen Ländern“ gearbeitet hat: „im Fernen Osten, zuerst...dann in Afrika für viele Jahre und...jetzt sieben Jahre in Indien“ [5]. Der Anreiz des Marktes ist so groß, dass seine Firma Bedingungen akzeptiert hat, wie „nirgendwo auf der Welt...äh... [Unsere Firma ist] der größte oder zweitgrößte Anbieter der Welt, die akzeptiert nirgendwo eine Minoritätenbeteiligung“ von $27 \%$ in einem Joint-Venture [ebd]. Und

„das Geschäft boomt hier wie verrückt. So habe ich das noch nie erlebt, in keinem anderen Land der Welt. Nicht mal in China, ähm, kommen wir nicht einmal annähernd an Wachstumsgrößen, die wir hier äh in Indien erreichen... Wir sind jetzt hier seit sechs Jahren tätig, äh, dieses Geschäft, ja, wenn sich das so weiterentwickelt, wie sich das jetzt abzeichnet, äh, dann haben wir...[bis zum] Ende unseres Geschäftsjahres in Indien - einen Umsatz von 2 Milliarden U.S.-Dollar, wir sind profitabel, wir beschäftigen dann 25.000 Mitarbeiter, wir haben dann wahrscheinlich 1500 Büros im ganzen Land und haben 200.000 Vertreter. Geben Sie mir irgendein Land auf der Welt, wo Sie das machen können!“ [5] 
Die Deutschen haben mit dem Standort Pune, was die Stadt als solche betrifft, ein ambivalentes Verhältnis, wenn nicht gar ein negatives: „Ja. Für mich ist es und für die meisten Ausländer ist Pune ein grausiges Nest" [5]. Aber:

„Die Inder finden Pune ja toll [...] Und, da die Inder Pune ganz schick finden, kommt Pune uns sogar entgegen, weil, äh, wenn wir eine head office-Position zu vergeben haben, äh, und es wird gesagt: ,Da musst du aber nach Pune ziehen', dann ist das für Inder kein Angang...für Inder sind hier die Lebensverhältnisse besser als in vielen anderen Metropolen...[Die] Infrastruktur immer noch besser als zum Beispiel in Bombay, ähm, die Verhältnisse nicht so teuer...sie kriegen hier relativ einfach Büro und Wohnraum. Sie kriegen relativ einfach Ausbildungsplätze für ihre Kinder und äh, Inder finden, dass Pune ein guter Standort ist; insofern ist das auch gar nicht, ist das gar nicht so schlecht" $[5]$.

Dass die indischen Mitarbeiter die Stadt Pune bevorzugen, spielt eine wichtige Rolle in Bezug auf den Arbeitsmarkt, wo die Attrition, der Jobwechsel, eines der größten Probleme darstellt (siehe unten).

Die Expats werden gestützt durch genügend Kapital und professionelles Wissen und Können. Ihre berufliche Leistung und ihre fachlichen Kenntnisse werden hier hoch geschätzt, und der deutsche Partner gar als lieber Gott gesehen:

„Alles was von Deutschland kommt, wird hier für bare Münze genommen. Deutschland ist da oben - technologiemäßig - in deren Meinung. Und die haben...den deutschen Partner als lieben Gott; und alles, was von denen kommt, wird befolgt" [9].

Nicht selten werden die deutschen Manager in die Rolle des Ausbilders gedrängt und die deutschen Unternehmen als beliebte Ausbildungsplätze angesehen - ein Sprungbrett für die weitere Karriere anderswo [5].

Die Schwierigkeiten in der Kommunikation mit den indischen Mitarbeitern, die die Sprache als solche betreffen, sind nicht gravierend. Firmen mit Kundschaft im deutschen Sprachraum haben einige deutschsprachige indische Angestellte, aber in der Regel: „Englisch wird im Business gesprochen und in der zivilisierten Welt“ [2]. Dass Inder Englisch beherrschen, wird als eine der wichtigsten vorteilhaften Voraussetzungen angesehen, eine Voraussetzung, die in Korea oder China fehle [9]. Fast keiner hat sich bemüht, eine regionale indische Sprache anzueignen bzw. wurde der Versuch bald aufgegeben. Nur wenige sind mit den lokalen indischen Sprachen überhaupt konfrontiert, insbesondere die Angestellten bei der Großindustrie, denn die haben fast ausschließlich mit den Kollegen aus der ,zivilisierten Welt" zu tun, abgesehen von etwa einem Kellner im Hotel [9] oder dem Chauffeur, der sie führt durch die Städte $[16,18]$. Dies ist möglich auch wegen des strengen hierarchischen Aufbaus der Firma. Je niedriger angesiedelt in der Hierarchie, desto weniger Englisch, aber es gibt genügend Zwischenstufen [2]. Akustisch verstehe man sich zumeist. „Ob man versteht, was man sagt und meint, das ist eine andere Sache“ [2]. 
Indien bedeutet allerdings eine Zumutung. Nach Indien komme man, sagte ein Interviewpartner, ,auf das Schlimmste vorbereitet“.? Auch wenn die Interviews nicht angelegt waren, um negative Aspekte zu unterstreichen, sondern eher den Modus der Zusammenarbeit hervorzuheben, kamen vor allem Themen zu Wort, in denen die Spannung zwischen den unterschiedlichen Arbeitswelten und Kommunikationsstrukturen deutlich zu spüren ist. Im Folgenden sind einige dieser Spannungsfelder zu nennen, weitere Spannungsfelder werden deutlich in der angehängten zusammenfassenden Kurzbeschreibung der 20 interviews (Teil III).

Indische Flexibilität ist in aller Munde. Der indische Markt ist flexibel, so auch die Mitarbeiter. Sie sind flexibel, was den Arbeitsstil und die Arbeitskultur betrifft, ebenso was den Arbeitsplatz selbst anbelangt. Attrition, Jobwechsel, ist ein generelles Problem [2, 8, 13]. Über häufigen Personalwechsel sogar auf der Führungsebene ohne „ordentliche Übergabe an Nachfolger“ beklagt sich auch Rudolf Jöbstl, Einkaufschef der Porzellanfabrik Frauenthal Holding AG, wie Zotz 2006 notiert. $^{10}$ Man muss damit rechnen, sagt ein Interviewpartner, ,dass Sie 15\% - typischerweise - von Leuten verlieren“ [8], ein anderer sagt: ,uns laufen 28 Prozent der Leute weg“ [5]. „Man kann eigentlich davon ausgehen“, sagt ein anderer: ,,jeder Mitarbeiter hat 3-4 Angebote in der Schublade liegen. Und wenn ihm etwas nicht passt, oder wenn er der Meinung ist, er braucht 30\% Gehaltserhöhung, und der Chef sagt, ...bleib erst mal ein Jahr bei uns, ... [dann] kann halt passieren, dass einige Leute direkt wieder gehen“" [13]. ${ }^{11}$ Man ist nie sicher, wer wann geht.

Dies bedeutet Verlust einer gerade angelernten Arbeitskraft sowie Informationsverlust. Eine Strategie gegen den Informationsverlust durch den plötzlichen Abgang eines Zuständigen ist: alles, jeden Arbeitsschritt, aufzuschreiben, was ein zusätzlicher Arbeits- und Zeitaufwand bedeutet. Das schriftliche Festhalten der getanen Arbeit kann aber auf Widerstand stoßen aufgrund einer besonderen Beziehung der indischen Mitarbeiter zu Schrift und Dokumentation (siehe unten). Ein Interviewpartner weiß allerdings den steten Abgang seiner bei ihm angelernten Angestellten positiv zu bewerten und sein Unternehmen als eine Ausbildungstätte zu schätzen: die Leute laufen weg, sie können weglaufen,

„weil wir so gut ausbilden, ja? Das heißt also ... für das nächste Jahr, für die nächsten zwölf Monate, müssen wir 27.000 Mitarbeiter ausbilden, und, 270 Vertreter, das heißt, wir sind im Grunde äh auf Hochtourenarbeit in der Ausbildungsorganisation für das indische [Finanzgewerbe]. Ja, das ist unsere wichtigste Aufgabe: Die Leute auszubilden!“ [5]

Die Tendenz zum Arbeitsplatzwechsel in diesem Maß $[5,8,12]$ deutet zwar auf die enorm gestiegene Nachfrage nach qualifiziertem Personal hin, aber auch auf die Unverbindlichkeit des Personals dem Arbeitgeber gegenüber, darauf, dass die Ar-

\footnotetext{
${ }^{9}$ Gupte/Müller-Gupte (2008), S.13

10 Zotz, Volker: Die neue Wirtschaftsmacht am Ganges. Strategien für langfristigen Erfolg in Indien, Heidelberg 2006, S.80

${ }^{11}$ Gupte/Müller-Gupte (2008), S.300-301
} 
beitnehmer sich mit der Firma nicht identifizieren. Allem Gerede von einer Corporate Identity zum Trotz ist der Arbeitgeber anonym und letztendlich egal, er ist allein der Geldgeber. Was einerseits fragen lässt, ob die Firmen sich mit ihrer eigenständigen Identität und Ideologie in der indischen Öffentlichkeit genügend profiliert haben. Andererseits beleuchtet dies aber auch das Ausmaß des Verantwortungsbewusstseins der indischen Mitarbeiter. Sie fühlen sich der Firma gegenüber nicht verantwortlich, wenn überhaupt, dann dem Chef gegenüber, ihm persönlich, als ihrem (Firmen-/Familien-)Oberhaupt.

Flexibilität in Bezug auf den Arbeitsstil ist eine gefragte Tugend, besonders in Indien, wo wegen Sachzwängen Pläne ständig umgeändert werden müssen. Aus gesicherten Strukturen kommend, sind die Deutschen damit konfrontiert, dass in Indien permanent mit Überraschendem gerechnet werden muss. Es passiert immer etwas Unvorhergesehenes. „Täglich gibt es zumindest eine Information, mit der man nicht gerechnet hat" ${ }^{12}$ Es ist so wenig vorhersehbar, berechenbar oder kalkulierbar, was passiert und passieren könnte, dass sich ein Gefühl steter Ungewissheit und Unsicherheit einschleicht; allzu oft werden Pläne durchkreuzt, man muss auf alles gefasst sein, im glücklichen Fall auch auf unerwartete Lösungen, nie bedachte Alternativen. Sollten sich die Produktionsbedingungen kurzfristig ändern, was oft geschieht, und die Arbeitsaufgaben modifiziert werden müssen, können sich die indischen Mitarbeiter sofort daran anpassen. Äußerste Flexibilität sowie multitasking gehören zu den indischen Arbeitstugenden.

Flexibilität bedeutet auch Unsicherheit, Unverbindlichkeit, und Unzuverlässlichkeit. Flexibilität und Unberechenbarkeit bestimmen das Verhaltens- und Kommunikationsmuster. Inder sind flexibel, was Zeit und Pünktlichkeit wie auch vertragliche Verbindlichkeit betrifft. Es kann sich bei offiziellen Treffen nicht um eine Verspätung von Minuten oder einer Viertelstunde handeln, sondern durchaus um eine von einer bis zwei Stunden. Es ist ratsam, wenn man zum Abendessen eingeladen wird, etwa 2 Stunden später zu erscheinen. Eine zeitliche Abmachung hat bloßen Orientierungswert. Um ein extremes aber typisches Beispiel zu geben: aus 5 verbindlich bestellten Containern wurden nur 2 verschifft. Nach vielen Beschwerden, Telefonaten und E-mails und nach ein paar Monaten waren die anderen Container endlich soweit und standen im Hafen; inzwischen hatten sich jedoch die Preise erhöht, und der indische Lieferant konnte nicht einsehen, wieso er sich noch an die alten, obwohl vertraglich festgehaltenen, Preise halten solle [2]. ${ }^{13}$ Das Argument, dass man dadurch, also durch die Kränkung eines wichtigen marktbeherrschenden Kunden in Deutschland einen schlechten Ruf bekäme, half nicht: "...ja. O.k. then we find another customer!". ${ }^{14}$

\footnotetext{
12 ebd., S.15

13 ebd., S.227

14 ebd., S.221, auch S.227
} 
Bemängelt wird das Fehlen einer langfristigen Planung. Das Neueste ist das wichtigste und alles andere kann unter den Tisch fallen. ${ }^{15}$ Dies mag als eine Strategie angesehen werden, den unvorhergesehenen Verzögerungen gerecht zu werden. Vereinbarungen werden richtungweisend, weniger verbindlich aufgefasst und müssen nicht unbedingt wortgetreu eingehalten werden. Alles wird ständig neu verhandelt. Man arbeitet gleichzeitig und parallel an verschiedenen Projekten und Aufgaben, funktioniert dieses nicht, dann aber eben jenes. Man macht, zugespitzt gesagt, gleichzeitig drei Termine mit drei Menschen in drei verschiedenen Stadtteilen aus, je nach dem in welchem Viertel man zur gegebenen Zeit im Verkehrsstau steckt, nimmt man dort den Termin wahr. So entstehen unvorhergesehene Probleme genauso überraschend wie nie geahnte Lösungen. ${ }^{16}$

Das Zurückliegende abschotten, entspricht auch der Beobachtung, dass Inder nicht nachtragend seien [2, 3, 9], ${ }^{17}$ heute streiten sie bis auf die Knochen, morgen haben sie es vergessen und gehen miteinander um, als sei nichts gewesen - zumindest auf der Oberfläche.

Abmachungen oder Versprechungen sind keine festen und verbindlichen Zusagen. ${ }^{18}$ Bekanntlich sagen Inder nicht „,nein“ [6] und mit einem "Ja“ sagen sie auch nicht unbedingt ,Ja“. Das indische „Ja“" ist genauso vieldeutig wie die dazugehörige Geste: das Wiegen des Kopfes anstatt des Schüttelns. Dies erfährt ein jeder Manager in dem interkulturellen Training vor seiner Ankunft in Indien. Wie kompliziert diese Ambivalenz seinen Berufsalltag tatsächlich gestaltet, erlebt er erst vor Ort. Das „bedingte“ Affirmative bzw. das Vermeiden des Negativen schafft 1. ein positives Arbeitsklima, zumindest an der Oberfläche; 2. unterstützt es den Hang zu Superlativen; 3. schaltet es offene Kritik aus - auch eine konstruktive Kritik innerhalb einer Verhandlung beispielsweise; und 4. verwischt es die Grenze zwischen der Realität und der Wunschvorstellung (siehe Teil II).

Es geht nicht nur um ja oder nein oder etwas dazwischen; im Allgemeinen drücken sich die Inder ungenau aus [6] und reden um die Sache herum. Es kann passieren, dass man einen Termin für eine wichtige Besprechung unter vier Augen ausmacht, in privater Atmosphäre. Man trifft sich, redet stundenlang, und erst bei der Verabschiedung, so zu sagen auf der Türschwelle, in der letzten Minute, kommt es zum eigentlichen Thema, das dann u. U. nicht ausreichend diskutiert werden kann [16].

Es wird um die Sache herumgeredet, Stunden lang diskutiert, ohne zu einem Ziel zu gelangen, ja ohne zu einem Ziel kommen zu wollen. Reden um Redens willen. Reden, auch nur um sich zu profilieren. Um eine Sache herum zu reden, entspricht der Neigung, sich nicht festlegen zu wollen. Nicht auf den Punkt zu kommen und vieles unbestimmt zu lassen, erlaubt Flexibilität, Pläne ständig zu

\footnotetext{
15 ebd., S.239

16 ebd., S.63, 238

17 ebd., S.23, 225

18 ebd., S.223
} 
ändern, Abgesprochenes erneut zu besprechen, und erst dann zu entscheiden, wenn es unter den Nägeln brennt, was wiederum nur zu kurzfristigen Lösungen führen kann. Das sorgt für erhebliche Irritationen bei den Deutschen, die langfristig planen. Auch die schriftliche Festlegung von Arbeitsaufgaben, im deutschen Verständnis ein selbstverständlicher wenn nicht gar notwendiger Schritt bei der Arbeitsorganisation, ist in einer typisch indischen Situation suspekt. Einerseits entspricht dies der indischen Tradition, die vorwiegend mündlich veranlagt ist, vielleicht auch, weil bis in die jüngste Vergangenheit die Schrift nicht allgemein zugänglich war, sondern Privileg einiger Weniger. Die schriftliche Festlegung, andererseits, erleichtert die Verantwortlichkeiten zu bestimmen, wovor die Inder sich scheuen. Bestenfalls wünscht man sich, mit einem Ja eine positive Antwort geben zu können.

„Typisches Beispiel: gestern kommt eine Zeichnung an - da habe ich gesagt: so nicht. Hier müssen wir dem Kunden sagen, dass wir diesen Wert nicht erreichen können. Das war die Ausziehkraft von unserem Bolzen. Und da hat er dann geschrieben: should be reviewed. Ja, ne, habe ich gesagt, das wird gestrichen: can not be made" [9].

Die eigenen Fähigkeiten werden falsch eingeschätzt: „Die denken: wir sind Inder. Ja: India is great; wir können's sowieso... Ja, weil meiner Ansicht das größte Problem des Landes ist, das auch die Entwicklung hemmt, dass ein bisschen zu viel Selbstbewusstsein vorhanden ist, oder ein bisschen zu viel Chauvinismus“ [6]. In keinem Land habe er Leute gefunden, die so perfekt von der Katastrophe als Erfolg berichten können, sagt ein Interviewpartner [6]. Bemerkenswert ist ein Hang zu Superlativen und zur Übertreibung - auch auf Kosten der fachlichen Mitteilung. Ein jeder ist der größte Experte, es wird in den höchsten Tönen gelobt und manches blumig dargestellt oder sich auch tatsächlich so vorgestellt, so dass Inder als „Phantasten“ vorkommen. Wo die Grenze zwischen Schein und Sein liegt, zwischen Wunsch-Vorstellung und Wirklichkeit, lässt sich für einen Deutschen, wohl strukturiert und handfest, schwer feststellen $[1,2,6]$.

Das Verneinen des Negativen sorgt für ein positives Klima, zumindest an der Oberfläche. Aus dem gleichen Grund wird offene Kritik vermieden, zumal die Kritik, auch wenn sachbedingt, als eine persönliche Beleidigung verstanden wird, die sogar in den Selbstmord treiben kann [18]. Trete ein Problem auf, wird dies auf einen persönlichen Fehler oder ein persönliches Versagen reduziert, und der Schuldige wird gesucht, dabei ist die Beseitigung des Problems zweitrangig. Daher kommt die Scheu, Arbeitsaufgaben klar delegiert zu bekommen und Verantwortlichkeit zu teilen. Am besten übernehme man gar keine Verantwortung oder, im schlimmsten Fall, um sich der Verantwortung zu entziehen, lüge man einfach. „Dass so viele Lügen passieren“[3], ${ }^{19}$ moniert eine Interviewpartnerin, Inder hätten ein ganz anderes Verhältnis von Lügen. Sie setzen sie ein, um andere und sich zu schützen und nicht konfrontativ Stellung beziehen zu müssen. Wie bei der Ver-

19 ebd., S.20, 73 u.a. 
bindlichkeit, ist man nämlich nicht der Firma sondern dem Chef gegenüber verantwortlich, verhält es sich auch hier. Fachspezifische Angelegenheiten werden stark personalisiert. Dies erklärt wiederum den übermäßigen Profilierungszwang, unter dem die indischen Mitarbeiter zu leiden scheinen, was die Teamarbeit erschwert $[16,17]$. Die Unfähigkeit der Inder im Team zu arbeiten, wird u. a. auf ihre Schulbildung zurückgeführt, die in der Regel aus Frontalunterricht besteht [6]. Inder sind gewohnt an einen streng hierarchischen Führungsstil. So bemerkt ein Interviewpartner entrüstet: ,ich bin überhaupt kein Anhänger eines autoritären Stils. Aber mit dem partizipativen Führungsstil hier in Indien - da geht's nur bergab mit der Firma. Ich musste eigentlich gegen meinen inneren Willen meinen Stil ändern und lernen, auch autoritär zu sein"“[6].

Die unterdrückten Konflikte durchbrechen mitunter die glatte Oberfläche; es wird laut geschrieen. Das Bild eines ruhigen, über allen Leidenschaften und irdischen Wünschen erhabenen Inders haben die deutschen Schriftsteller und Denker des 19. Jahrhunderts in die Welt gesetzt, die wohl in Indien nie gearbeitet haben. Wutanfälle gehören zum Alltag. Dass auch sie dazu fähig sind, haben manche Deutsche erst in Indien erfahren [9]. Die Ausbrüche haben allerdings einen anderen Stellenwert; es wird eine akute Spannung ausgedrückt, die sich aber nicht nachtragend auswirkt.

\section{II}

Anke Müller-Gupte

Aus den Schilderungen der Interviewten offenbart sich das Leben in Indien in großer Vielschichtigkeit, ungeheuerer Vielfalt und tausend Überraschungen, was in etwa so auch für das Arbeitsleben in Indien zutrifft.

Neben Beschreibungen beglückender und fruchtbarer Zusammenarbeit wird in nahezu allen Interviews von überraschenden Reaktionen, unerklärlichem Verhalten wie auch krisenhaften Begegnungen und Ereignissen berichtet. Diese sollen nicht auf kritische Eigenarten der jeweiligen Kultur hin analysiert werden, als vielmehr helfen, den Bereich der gemeinsamen Welt der Arbeit möglichst genau in den Blick zu nehmen. Es wird davon ausgegangen, dass sich im gemeinsamen Arbeitsalltag eine Kultur des Miteinander ausbildet, deren Eigenheit sich zwar auch aus den jeweils kulturellen Spezifika ableitet, nach Thomas im Begriff des Kulturstandards zusammengefasste typische Verhaltensweisen der jeweiligen Kultur, dass diese in der gemeinsamen Arbeitswelt, in der die jeweiligen Menschen aufeinander reagieren, jedoch nuanciert und variiert werden, so dass es zum Entwickeln einer von Müller-Jacquier so genannten „Inter-Kultur“ kommt, in der die angelegten Unterschiede nicht selten gar verschärft werden. Neben individuellen und kulturellen 
beeinflussen desweiteren sehr viel mehr, u. a. situative und strukturelle Variablen, wie z.B. der jeweilige Status und die soziale Situation, das Verhalten der Beteiligten. Es soll spezifiziert werden, an welchen Stellen es - aus Sicht der Interviewten - zu kritischen und problematischen Situationen kommt, das Zusammentreffen, die Schnittstelle genauer zu untersuchen, um das psychologische Grundproblem, mit dem sich die Interviewten auseinanderzusetzen haben, herausarbeiten zu können.

Aus den Beschreibungen der Interviewten lässt sich erkennen, dass es zu Problemen kommt, wenn von ihnen erwartetes und als selbstverständlich angenommenes Verhalten nicht eintritt.

Die Reaktionen indischer Kollegen, Mitarbeiter, Kunden und Vertragspartner verblüffen die Interviewten, da sie außerhalb ihres Verständnisrahmens liegen und oft gar nicht für möglich gehalten werden. Sie folgen nicht dem eigenen, sehr rationalen Verständnis und erscheinen ihnen nicht angemessen an das, was Arbeitssituation, Arbeitsinhalt und Arbeitsaufgabe, Arbeitsvertrag fordern. Sie entspringen offensichtlich einem anderen Verständnis mit anderen Prioritäten, als es die Arbeitswelt zu dirigieren scheint.

Aus Sicht der Deutschen werden die Anforderungen der Arbeitswelt von indischer Seite mitunter einfach ignoriert. Normen, die im deutschen Arbeitsalltag selbstverständlich sind, werden ausgehebelt. Dazu gehört Unpünktlichkeit, bei der es sich nicht um 5-10 Minuten handelt, was aus deutscher Sicht auch schon zu viel ist, sondern um eine oder auch mal zwei Stunden, die Teilnehmer einer Besprechung zu spät kommen. Es wird ergänzt von unterschiedlichem inhaltlichem Verständnis, wenn Arbeitsaufgaben zur vereinbarten Zeit nicht erfüllt bzw. unvollständig und ungenau erledigt werden. ${ }^{20}$ Es zählen dazu vage und mehrdeutige Stellungnahmen wie auch Geschichten, deren Inhalte mehr der Phantasie als der Realität entspringen. Es werden zu jeglichen Ereignissen Begründungen vorgetragen, was die Interviewten als Ausreden und Lügen wahrnehmen. Die, aus deutscher Sicht, so grundlegende und wichtige Planung braucht Verlässlichkeit, um kalkulieren zu können, die nicht gegeben ist. Nicht nur eine Folge dessen ist, dass Pläne immer wieder korrigiert und verändert werden und selbst bei großzügiger Zeitplanung beweglich gehalten werden müssen. Alles ist immer wieder neu verhandelbar. Das Denken der Inder wird als ein anderes empfunden, das weniger auf einen Überblick, ein System und ein Ziel bezogen ist, als auf den Moment, auf die augenblickliche Atmosphäre, das eigene Befinden im Augenblick, dem Verhalten und Äußerungen untergeordnet werden. Es wirkt daher spontan und erscheint egoistisch und selbstbezogen - ganz besonders, wenn es mit Superlativen und unwahren Übertreibungen bis hin zu - Fälschungen von Zeugnissen gespickt wird.

Aus deutscher Sicht erscheint diese Art von Verhalten emotional, unberechenbar und dem eigenen Befinden mehr verpflichtet als den Anforderungen des Ar-

\footnotetext{
${ }^{20}$ Es handelt sich diesbzgl. nicht um sprachliche Kommunikationsprobleme. Die Interviewten betonen, dass es auf der Ebene der Entscheidungen mit der Geschäftssprache Englisch keine Probleme gäbe (siehe auch Teil I).
} 
beitslebens. Das verweist auf den Kontrast zwischen den Forderungen des Arbeitslebens und dem Wunsch, sich nach eigenen Prioritäten verhalten zu wollen. Es offenbart sich als ein Gegensatz zwischen den Pflichten, Aufgaben und moralischen Ansprüchen der Arbeitswelt und dem Wunsch, auf das eigene Befinden Rücksicht nehmen, der eigenen Lust und Phantasie, den eigenen Bedürfnissen nachgehen, und die Unlust, die womöglich mit eben diesen Anforderungen der Arbeitswelt verbunden ist, vermeiden zu wollen.

In diesem Gegensatz lässt sich auf die Spannung verweisen, die Sigmund Freud ursprünglich veranlasste, das Realitäts- vom Lustprinzip zu unterscheiden. Ohne der Theorie Freud's stringent folgen zu wollen, sollen die beiden Prinzipien hier helfen, zwei grundverschiedene Umgangsweisen mit der Wirklichkeit darzulegen.

Bezogen auf die vorliegende Studie umfasst das so genannte Realitätsprinzip das, was im Allgemeinen unter deutscher Arbeitsethik verstanden wird, wie das angemessene, verantwortungsbewusste Eingehen auf die Anforderungen der realen Arbeitswelt, das Erfüllen von Arbeitsaufgaben, das Einhalten von Terminen, die Verbindlichkeit von Absprachen, Höflichkeit, Pünktlichkeit, Gewissenhaftigkeit, Verlässlichkeit usw. Dazu bedient es sich einer rationalen Herangehensweise. Mit Fleiß, Ausdauer, Genauigkeit wird letztlich Erfolg möglich, kommt es zu besonderer Leistung, damit auch zu Belohnung, Geld, Reichtum, zu einer erfolgreichen Entwicklung. Es besagt, dass eine Handlung ebenso wie eine Nicht-Handlung Konsequenzen nach sich zieht. Nach allgemeinem - nicht allein deutschem - Verständnis funktioniert die Arbeitswelt nach diesen Regeln. Wirtschafts- und Marktentwicklung scheinen die Notwendigkeit solcher Verhaltensnormen für eine erfolgreiche Entwicklung zu bestätigen.

Während das Real-Ich nach Nutzen strebt und sich gegen Schaden sichert, verfolgt das Lust-Ich die Wünsche nach Lustgewinn. Der Begriff Lustprinzip meint die universelle Tendenz, Schmerz und Unlust vermeiden und sich Lust, i. S. von Wohlgefühl, verschaffen zu wollen. Das Lustprinzip funktioniert nach einer eigenen Logik, die der des Traumes ähnlich ist, wo - abgekoppelt von der faktischen Realität - alles denkbar und möglich ist und praktische Konsequenzen zunächst ausbleiben, in der die Phantasie lenken und leiten, vieles parallel geschehen kann, und wo es um das unmittelbare Jetzt geht - gesehen aus dem Blickwinkel des jeweiligen, ohne Beachtung und besondere Rücksichtnahme auf die soziale Situation, andere Menschen oder andere zeitliche Perspektiven.

Das Verhalten der indischen Kollegen, Gesprächspartner oder Kunden, das die Interviewten verblüfft, scheint einem derartigen Umgang zu ähneln. Es verweist auf einen unmittelbareren Umgang mit Geschehnissen unabhängig von inhaltlichen und zeitlichen Perspektiven, von Vereinbarungen, unabhängig von ,den anderen', zunächst auf die eigene Position bezogen.

Häufig und gern verwendete Superlative und Übertreibungen deuten auf das Bedürfnis, sich selbst als den/die Beste zu phantasieren, und entspricht dem Wunsch nach eigener Erhöhung, wie es das Lustprinzip fordert. Dem sind auch 
das Erfinden von Geschichten und Lügen zuzuordnen, die die eigene Person zu schützen oder zu erhöhen haben - neben der Phantasie, die sich da durchzusetzen vermag.

Mit diesem Verständnis von Prioritäten kommt der Unmittelbarkeit große Bedeutung zu. Herzlichkeit, Offenheit wie auch Verletzlichkeit werden erlebbar. Das Verheimlichen von Tatsachen zum Schutz der eigenen Person oder zum Erhalt der momentan guten Atmosphäre gehört dazu. Phantasie, große Improvisationsfähigkeit und unbegrenzte Flexibilität können sich entfalten. Immer ist - scheinbar alles möglich, zumindest denkbar, daher werden Konsequenzen und Folgen des eigenen Tuns nicht wahrgenommen, wie z.B. der Zusammenhang von unterlassener Leistung und weniger Geld nicht gesehen wird. Es wird gern viel geredet und debattiert - nicht zielorientiert, viel mehr um weitere Möglichkeiten zu finden. Utopische Ziele reizen und müssen vom Chef auf machbare chunks herunter gebrochen werden, wie es ein Interviewter formulierte. Vergebene Aufträge müssen überwacht und kontrolliert werden, ähnlich wie Eltern ein Kind immer wieder zu ermahnen haben, bei großen (z.B. Berufs-) Zielen doch die alltäglichen Aufgaben wie für die Schule zu erfüllen. Mit dem Primat des Lustprinzips wird es möglich, parallel an mehreren Sachen zu arbeiten/zu spielen, je nachdem wohin die Phantasie gerade trägt. Prioritäten werden gesetzt von der eigenen Lust und den Erfordernissen des Hier und Jetzt. In der Planlosigkeit ist stets alles möglich; immer kann eine Idee entwickelt, ergänzt und verfolgt werden, immer können Phantasien gesponnen werden, ohne schon im Keim an realen Begebenheiten zerbrechen zu müssen. So gibt es unendlich viele Initiativen und Aktionen, die einfach mal gemacht werden, ohne den nächsten Schritt zu bedenken, und die dann möglicherweise auch an der weiteren Verwirklichung scheitern, aber doch erst mal begonnen werden. Genauigkeit, Exaktheit, Präzision spielen keine so große Rolle, es geht ums ,Überhaupt'. So kommt es zur Wahrnehmung der Inder als Traumtänzer wie auch zu der von Interviewten beklagten mangelnden, so benannten Professionalität, die einen den Deutschen gewohnten Arbeitsablauf blockiert. Die Beharrlichkeit, mit der etwas - wissenschaftlich Unhaltbares - behauptet werde; die Sturheit, mit der daran festgehalten werde, zeugen mehr von dem Wunsch der eigenen Unfehlbarkeit als von der Realität und sind somit dem Lustprinzip verpflichtet. „Ich habe in keinem Land Leute gefunden, die so perfekt von der Katastrophe als Erfolg berichten können", sagt ein Interviewter - auch dies eine Reaktion, die den Wunsch als Vater des Gedanken hat. Die Fähigkeit, nach Auseinandersetzungen und heftigem Streit relativ schnell wieder etwas miteinander anfangen zu können, nicht nachtragend zu sein, verweist auf die Bedeutung der Unmittelbarkeit des Geschehens.

Mit diesem Verständnis ist vieles denkbar, machbar, kombinierbar, was ansonsten absurd erschiene, zu umständlich, zu chaotisch oder eben der Realität nicht angemessen. In der Welt der Phantasie, Magie und Vorstellung aber ist es durchaus sinnvoll und hat seinen Stellenwert, ebenso wie die Bedeutung des Ein- 
fühlens, des Erspürens von Gegebenheiten - unabhängig von faktischen Tatsachen.

Nach Freud sind vor allem Kinder in der Lage, nach dem Lustprinzip zu leben. Sie geben ihren Wünschen und Bedürfnissen unmittelbar Ausdruck, um sie sofort und vollständig zu befriedigen und ungute Gefühle zu vermeiden. Ihr Umfeld sehen sie bestehend aus Personen, die zur eigenen Bedürfnisbefriedigung herangezogen werden und nicht auch eigene Bedürfnisse haben.

Dem entwicklungspsychologischen Gedanken, wonach Reife mit Erwachsenwerden zu tun hat, wird hier keine Beachtung geschenkt, ebenso wenig der Ansicht, wonach Kindsein einer früheren „primitiveren“ Stufe des Erwachsenseins entspricht. Vielmehr soll mit der Darstellung der Unterschiede in den Wahrnehmungen der Interviewten und deren Analyse eine Würdigung der Andersartigkeit und durch die Betrachtung dieser spezifischen Fähigkeiten und Eigenschaften, dem eindimensionalen Verständnis von Entwicklung entgegengewirkt werden. Die Besonderheiten der Betrachtung von Phänomenen, wie sie Kindern eigen sind, verweisen auf andere Prioritäten und somit Perspektiven und Lösungsansätze, als sie rational denkenden Erwachsenen zunächst einfallen würden. Sie eröffnen andere Dimensionen und Alternativen, die das Verhaltensrepertoire und das Gemütsleben bereichern können. Insofern wird kolonialen Denkweisen, die Inder mit Kindern verglichen und damit auf eine primitivere Stufe zu stellen beabsichtigten, hier eine andere Sicht entgegen gestellt.

Die kindliche Logik funktioniert - nach Freud - weitgehend nach dem Lustprinzip. Wobei auch Kinder frühzeitig merken und lernen, welchen Regeln und Normen der Gesellschaft sie zu folgen haben, die die Herrschaft des Lustprinzips einschränken.

Im Verlauf der Erziehung, des Erwachsenwerdens soll nach westlichem/deutschem Verständnis das Kind lernen, sich den Anforderungen des Lebens zu stellen, Pflichten und Aufgaben zu übernehmen - selbständig und eigenverantwortlich. Der Wunsch nach unmittelbarer Befriedigung soll zurückgedrängt, aufgeschoben, sublimiert, verändert oder endgültig ins Reich der Träume und Künste verbannt werden; d.h. zu verzichten auf viele Möglichkeiten direkter Bedürfnisbefriedung und in Kauf nehmen von vorübergehender Unlust, die mit diesen Pflichten verbunden ist, bis durch die Ergebnisse und Resultate letztlich auch wieder Befriedigung erlangt werden kann. Damit ist das Realitätsprinzip beschrieben, dem sich das Lustprinzip unterzuordnen hat. Das ist, was unter Erziehung verstanden wird: Einsicht in Notwendigkeiten der Erwachsenenwelt, Arbeit mit Pflichten und Aufgaben. Die Lust bleibt dabei zunächst weitgehend auf der Strecke. Stattdessen sollen im Späteren Erfolge und Leistungen befriedigen. Unsere deutsche Arbeitsmoral verdanken wir maßgeblich dieser so ausgerichteten Erziehung, in der uns nach Vorstellung der Gesellschaft, verfestigt von historischem Geschehen, Normen und Werte dieser Erwachsenenwelt beigebracht werden. Diese Erziehung macht Kindern keinen Spaß und kostet in aller Regel viel Mühe ( - nicht nur den Kindern). Das, was vergnügt, muss hinten angestellt, stattdessen 
Unerfreuliches nach Priorität der Erwachsenen zuerst erledigt werden. Einsicht entscheidet, nicht Wohlgefühl über das $\mathrm{Zu}$ Tuende. Damit soll verdeutlicht werden, dass diese Arbeitsmoral mühevoll erkämpft werden muss - und folglich entschieden verteidigt wird, sobald sie verinnerlicht ist. Der Erwachsene will sozusagen zeigen, dass er die Lektion verstanden hat, und sie voller Überzeugung seinen Kindern wieder zuteil werden lassen.

Das Vertrackte ist, dass sich die beiden Prinzipien, Lust- und Realitätsprinzip, in ihrem ursprünglichen Sinn gegenseitig ausschließen. Sie sind miteinander unvereinbar. Es lässt sich jeweils nur eines von Beiden verwirklichen. Das ist ein Grundparadox, mit dem sich nach Freud der Mensch im Laufe seiner Entwicklung $\mathrm{zu}$ arrangieren hat. Um den Anforderungen einer leistungsorientierten Gesellschaft und somit auch ihrer Arbeitswelt gerecht zu werden, soll sich das Realitätsprinzip durchsetzen und das Lustprinzip überwunden werden. Den ureigenen Bedürfnissen und Gelüsten nachzukommen, bleibt eine Option allenfalls für die ,Freizeit' und auch dann in angepasster, kulturadäquater Weise. So lassen sich Bedürfnisse in bestimmten Bereichen wie Kunst, Kultur und Sport sozial und kulturell akzeptiert ausleben. Ansonsten können die verschiedensten Abwehrmechanismen mobilisiert werden, um unlustvolle Gefühle, Affekte und Wahrnehmungen vom Bewusstsein fernzuhalten, sie zu verdrängen, oder andere Formen wie Erkrankungen finden, sie auszudrücken.

Im Arbeitsleben von Deutschen in Indien prallen die beiden Prinzipien aufeinander und verweisen auf diese Unvereinbarkeit. Die Interviewten werden konfrontiert mit Verhalten, das ihnen wie eine Zumutung erscheint; Verhalten, das sie sich seit ihrer Kindheit haben abgewöhnen müssen, das nicht den Verpflichtungen der Arbeitswelt gehorcht, sondern ihnen diametral entgegen zu stehen scheint. Es wird irritiert wahrgenommen, sich im ,Business-Leben' mit eigenwilligem, unberechenbarem Verhalten auseinandersetzen zu müssen. Es erscheint unverständlich, unlogisch, chaotisch. Die bekannten und bewährten Verhaltensnormen werden außer Kraft gesetzt und von etwas ersetzt, dem mit einem auf die faktische Realität bezogenem Verhalten, einem vollkommen rational logischen Verständnis, nicht begegnet werden kann. Das ist der Moment, wo die anfängliche Verblüffung der Interviewten über unerwartetes Verhalten umschlagen kann in Wut und massive Verärgerung. Es wird auf emotionale Reaktionen zurückgegriffen und dem Ärger Ausdruck verliehen in der Auseinandersetzung mit diesem ,unvernünftigen' Verhalten. Mit diesem, Ausrutscher' in die Welt der Emotionen erfahren die Interviewten zugleich wiederum eine nicht erwartete Reaktion, nämlich dass das von indischer Seite sehr gelassen aufgenommen wird und keinerlei Verstörung oder Konsequenz zur Folge hat. Diese Art von Reaktion erscheint Indern und Inderinnen weniger befremdlich als den Interviewten selbst und offensichtlich nahe liegender als eine kognitive Auseinandersetzung mit dem Vorgefallenen. Die Interviewten ihrerseits sind auf sich selbst zurückgeworfen und gezwungen, sich mit ihren unmittelbaren Gefühlen auseinanderzusetzen - sowohl eine Chance als auch Irritation. Sie spüren Toleranz wie auch Gleichgültigkeit. Sie beginnen zu ahnen, 
dass ein sicheres „Bauchgefühl“ und Intuition mehr Klarheit bringen kann als die Auseinandersetzung auf Verstandesebene. „Man kann diese Kultur nicht einfach rational angehen", sagt ein Interviewter.

Das Dilemma der Interviewten lässt sich in etwa so beschreiben: in der Verantwortung für das Funktionieren der Arbeitswelt, in der es um Maximierung von Nutzen und Gewinn sowie Minimierung von Schäden geht, dem Realitätsprinzip verpflichtet, konfrontiert zu sein mit den Wirkungen des mit dem Realitätsprinzip wohl nicht direkt zu vereinbarenden Lustprinzips, das zudem die eigene Person unbewusst unter ,Befriedigungswunsch'-Druck setzt und ihre eigene Unlust spürbar macht.

Natürlich leben auch die Inder und Inderinnen nicht in einer Traumwelt, geleitet von ihren Wünschen und Bedürfnissen. Auch sie folgen Regeln und Ordnungen, die Richtlinien des Verhaltens geben. Diese sind nicht leicht zu erschließen für Deutsche. Am ehesten werden sie - oft überrascht - wahrgenommen in der nach wie vor wirksamen Kastenordnung mit all ihren impliziten Regeln, der hierarchischen Ordnung, der Zuordnung bestimmter Arbeitsaufgaben, um nur die offensichtlichsten zu nennen.

Eine zentrale Rolle bei der Vermittlung von Regeln, Aufgaben und Pflichten kommt der Familie zu, der sich nahezu alles unterordnet, und deren Struktur auch auf außerfamiliäre Bereiche übertragen wird, so dass der Firma mit ihrem Chef noch ganz andere Funktionen zugeteilt werden als die über die Arbeitsaufgaben diktierten.

Zudem hat die Religion eine sehr große Bedeutung. Ganz abgesehen von der Vielfalt der Glaubensrichtungen, die in Indien gelebt werden, wirkt allein die Üppigkeit, Vielschichtigkeit und Unendlichkeit der hinduistischen Gottheiten und ihrer Geschichten einerseits faszinierend und zugleich befremdend für Menschen aus dem christlichen Abendland, die in ihrer Religion überschaubare Verhältnisse gewohnt sind und - auch da - klare Richtlinien vermittelt kriegen, die sich in 10 Geboten auf den Punkt bringen lassen. Die Welt der hinduistischen Religion, von Mythen und Geschichten erscheint übermäßig vielfältig, undurchschaubar, sehr phantastisch und bleibt in ihrer tiefen Bedeutung vielen Europäern weitgehend fremd. Allenfalls touristisch lernen Interviewte Tempel kennen und religiöse Feste. Nur in ganz unerwarteten, eher zufälligen Begegnungen kann die Tiefe und Ernsthaftigkeit bei der Befolgung ihrer Regeln geahnt werden. So wenn ein Interviewter aus Versehen in die allmorgendliche Puja des Chefs platzt und ihn tief versunken vorfindet. Oder wenn das Leben im Tempel als Insel der Ruhe ungemein friedvoll und wohltuend erlebt wird. Das Regelwerk der Religion bleibt den Interviewten vielfach verschlossen und unverständlich. Es ist allenfalls eine Ahnung, dass da mehr ist, was offensichtlich tief wirkt und eine Struktur vorgibt.

Diejenigen Interviewten, die sich philosophische Fragen stellen, und auf der Suche nach etwas ,Eigentlichem' im Leben, vielleicht einem anderen Zugang wie Umgang mit Wirklichkeit sind, öffnen sich der indischen Vielfältigkeit, tolerieren das Unbestimmte, Vage, Mehrdeutige leichter. Sie vermeiden zugleich, zu fest in 
die Verpflichtungen, die das Realitätsprinzip mit sich bringt, verstrickt zu werden und versuchen das Ausmaß der Forderungen der Arbeitswelt von vornherein zu minimieren. Soweit möglich gestalten sie ihren Arbeitstag beweglicher und entschärfen somit vorgegebene Zwänge.

Im Ausrasten, in Wutanfällen und Schreien von Deutschen kommt das unmittelbare Gefühl, der Ärger und das Unlust-Vermeiden-Wollen, zum Ausdruck. Die Nicht-Reaktion der Inder auf einen solchen Ausbruch lässt sich auch verstehen als ein Verweis auf die Logik des Traumes, in dem keine Konsequenzen zu fürchten sind, aber auch keine Re-Aktionen erwartet werden können. Auch in der Traumlogik gibt es Regeln, nach denen sie funktioniert wie Verdichtung, Verschiebung, Verkehrung - es ist kein Chaos, kein unerklärliches Durcheinander, aber es geht auf Kosten der Handlungsfähigkeit, wenn diese Traumwelt im Alltag gelebt wird. D.h. wenn alles möglich ist und auch so gehalten werden soll, kann man sich nicht für eine konkrete Handlung, eine Tat einsetzen, denn diese Entschiedenheit verhindert andere Möglichkeiten, die nicht ausgeschlossen werden sollen. Das lässt sich - bis zu einem gewissen Grad - leben. Aber wie weit kann es gehen mit der Offenheit für alle Alternativen und der damit verbundenen Konsequenzlosigkeit? Dann wird womöglich versucht, ,in der Minus neunten Minute in einer Nacht Rom zu versetzen“, wie ein Interviewter formulierte.

Lässt sich das Realitätsprinzip - zumindest zeitweise - aushebeln? Ist es möglich, sich mit dem Lustprinzip in der Welt der Wirtschaft zu behaupten? Wie ließe es sich in die Arbeitswelt, gewinnbringend' integrieren? Wo setzt es definitiv Grenzen? Zeigt der Trend nach immer höher steigenden Gehaltsforderungen der Inder und Inderinnen die wachsende Bedeutung des eigenen Nutzens, den Einfluss des Realitätsprinzips?

Es stellt sich die Frage, welche Rolle der Religion, der Familie, der Kastenordnung wie auch den gegebenen infrastrukturellen und soziokulturellen Umständen zukommt bei der Vermittlung zwischen dem Bedürfnis nach unmittelbarem Verhalten und den Anforderungen eines modernen Arbeitslebens, das sich den Regeln der Wirtschaft unterzuordnen hat? Wie kann sich das geschichtlich Gewordene, sozial Bewährte, wie können sich traditionelle Umgangsweisen in Indien aussöhnen mit den Forderungen eines modernen, von der Industrialisierung geprägten, gesellschaftlichen Lebens. Ist es überhaupt ratsam, sich dem so genannten Realitätsprinzip mehr unterzuordnen, wo man schon in so vielen Zwängen fest hängt, in so vielen Bereichen gehorchen' muss und Zugeständnisse zu machen hat? Braucht es nicht diese ,kleinen Freiheiten', um der Fremdbestimmung etwas entgegen zu setzen und sich als ICH erleben zu können? Müssen bestehende, traditionelle Verpflichtungen wie z.B. in der Familie gelockert werden, um neue Verbindlichkeiten, die ein westliches Verständnis von Arbeit fordert, eingehen zu können? Ist es nicht die einzige Möglichkeit, Einfluss auf das Bestehen einer guten Atmosphäre nehmen zu können, wenn man einer optimistischen Sicht mehr Ausdruck verleiht, als einem realitätsbezogenen, eher pessimistisch anmutenden Blick erliegen zu müssen, der einen zu schnell erdrücken könnte? 
Inwiefern wiederum lässt sich in das Realitätsprinzip mehr Beweglichkeit bringen? Wo wird es zum sturen Befolgen von Regeln und Arbeitsschritten, die kaum mehr Kreativität ermöglichen?

Der Dichotomie des Begriffspaares entgegenzuwirken, sollte bedacht werden, dass es natürlich möglich ist, der Arbeit mit Lust nachzugehen. Es gilt, realisierbare Mischungen zu finden, den täglichen Forderungen der Arbeit zu entsprechen ohne sich von sich selbst entfremdet zu empfinden. Die Befriedigung durch die Arbeit kann dem Ich zur Stärkung dienen und kann ihm andere Freiheiten verschaffen, denen es sich außerhalb der Arbeitszeit widmet. Es ist die Frage, inwieweit sich dies hier und jetzt für indische Arbeitgeber und Arbeitnehmer, und -nehmerinnen realisieren lässt, ob dies nicht eher einem westlichen Verständnis von Arbeit und Freizeit, Ich-Verwirklichung und Glücksanspruch entspricht. Ermöglichen die Bindungen und Strukturen, in denen die Mehrzahl der indischen Menschen leben, überhaupt eine derartige Gestaltung ihres Lebens?

Das Realitätsprinzip ist ebenso wie das Lustprinzip Freuds europäischem Hirn entsprungen. Sie wurden daher als angemessen empfunden zur Verdeutlichtung der strukturellen Spannungen, wie sie von Deutschen, Deutschsprachigen beim Erleben ihres Arbeitslebens in Indien wahrgenommen werden. Um die andere Seite zu beleuchten, nämlich wie sich diese Arbeitswirklichkeit aus indischer Sicht darstellt, muss geprüft werden, inwieweit dieses theoretische Konstrukt und sein europäischer Gedankenhintergrund geeignet sind, die Phänomene, wie sie von Inderinnen und Indern wahrgenommen werden, und deren Hintergründe wiederzuspiegeln.

\section{I}

\section{Zusammenfassende Beschreibung von 20 Interviews}

Nach Indien kommt man auf's Schlimmste vorbereitet oder auf der Suche nach transzendentaler Realität [20].

Es schockiert der Verkehr, mit dem Distanzgefühl aus Europa erschrickt man vor der Nähe, „wie eng man aneinander vorbei fährt“ [18] - wie nah einem alles kommt, wie dicht es werden kann. Es irritiert die vermutete Einstellung der Inder, die einem rücksichtslos oder als „unbedachte Unbedarftheit“ anmutet wie auch ich-bezogen, unsozial oder schlicht gefährlich erscheint, wenn sie z.B. mit ihren Familien über die Autobahn spazieren gehen [4]. Die Fülle an Farben und Gerüchen betäuben; die Freundlichkeit, das "indische Lachen", beeindrucken [10, 16, 18 u.a.]. Vertraute Begrüßungs- und Höflichkeitsgesten werden vermisst [1]. Das indische Lächeln befriedet immer wieder [2, 4, 9, 10, 12], es werde getragen von einer unheimlichen Humanität, Zuwendung und einer Fähigkeit zum Mitleiden. „Es gibt mehr Akzeptanz für das Leben, wenn es auch voller Leiden und Schwierigkeiten ist" [10]. Vieles zeige sich sehr extrem, wie zum Beispiel wenn das Ehrge- 
fühl in den Selbstmord treibt, weil man vor den Augen anderer kritisiert wurde [18].

Der Anblick von Chaos, Dreck und Armut auf den Straßen erschüttert. „Man muss lernen zu verdrängen." [1, 4, 16, 18]. Die bettelnden Kinder an den Kreuzungen - das ist schwer zu ertragen. Das Elend macht fassungslos und hilflos zumal einem geraten wurde kein Geld zu geben $[1,4,6,9,12,16,17,18]$.

Auf die ganz normalen Alltagsherausforderungen, wie den Einkauf von Dingen, um den Haushalt in Gang zu bringen, Telefon- und Internetanschluss einrichten zu lassen oder ein Bankkonto zu eröffnen, fühlen sich die Interviewten nicht vorbereitet. Sie geraten zu Anstrengungen, gar Zumutungen, „da es keinerlei Kundenservice gibt“ [7]. Ganz besonders haarig wird die Erfahrung bei der Ausländerbehörde. „Man wird da behandelt wie der letzte Hinteridiot, also wirklich schäbig behandelt" [14]. Diese Erfahrungen außerhalb der Arbeit ermöglichen viel Nähe zur indischen Kultur, zu indischen Umgangsformen, und erschweren sie sogleich, da sie mit Befremden wahrgenommen werden, das Distanz schafft.

Die eigentliche Arbeitsaufgabe in Indien ist für die Interviewten in aller Regel eine gern angenommene Herausforderung, oft mit einer Erweiterung der konkreten Aufgaben und Befugnisse verbunden und somit auch an größere Verantwortungsbereiche. Das reizt die Interviewten. Es verheißt Erfahrungen, die auch im weiteren Berufsleben weiterbringen sollen. Selbst wenn das Arbeitsgebiet eines ist, das die Interviewten später nicht weiter betreiben werden, erleben sie eine Bereicherung an Erfahrung, die niemand mehr wegnehmen könne, was sie später auch tun und wo immer sie sich aufhalten werden $[2,3,4,6,7,8,11,12,13,15,16,18]$. Die Arbeit in Indien wird als eine erlebt, bei der man noch etwas bewegen könne $[5,6,8,17]$. Aber anders als früher, als die Medien einen noch nicht überall erreichten, empfinden sie nicht mehr eine solche Freiheit allein, d.h. ohne Rückantwort des heimischen Head Office, Entscheidungen treffen zu können [17]. Unabhängig ob die Firma nach nahezu deutschen ${ }^{21}$ Regeln läuft, wo es etwas abgefedert ist, oder als rein indisch einzuordnen ist, muss in Indien permanent mit Überraschendem gerechnet werden. Es passiert immer etwas Unvorhergesehenes [1, 2, 6, 7, 8, 12, 13, 16, 18, 20]. Täglich gibt es zumindest eine Information, mit der man nicht gerechnet hat $[1,2,3,7,12,16,18]$. Es ist so wenig vorhersehbar, berechenbar oder kalkulierbar, was passiert und passieren könnte, dass sich ein Gefühl steter Ungewissheit und Unsicherheit einschleicht. Allzu oft werden Pläne durchkreuzt, man muss auf alles gefasst sein - im besten Fall auch auf unerwartete Lösungen, nie bedachte Alternativen $[1,2,3,4,5,6,7,9,10,11,12,13,14,15,16,17$, 18, 19]. "Es ist generell anstrengender, weil einfach auch so vieles schief gehen kann und so vieles gut klappen kann - beides schwer vorhersehbar“ [2]. „Es ist typischerweise immer sehr viel los in Indien“: ein Markt, der gerade boomt - mit Opportunitäten und Risiken. „Da müssen Sie deutlich schneller und flexibler rea-

\footnotetext{
${ }^{21}$ Die Bezeichnung ,deutsch' wird im Folgenden der Einfachheit halber für den gesamten deutschen Sprachraum verwendet, aus dem die Interviewten kommen.
} 
gieren können als in einer vergleichbaren Position in Deutschland. In Indien müsse man ,in der Lage sein, kreatives Chaos zu beherrschen, weil einfach doch relativ viel immer noch passiert - ob irgendwo ein Container ins Wasser fällt, oder irgendwo gibt es Riots, oder aber was weiß ich - persönliche Schicksale“ [8].

Nun zur konkreten Beschreibung der Kommunikation im beruflichen Alltag: In - ausnahmslos - allen Interviews erscheint die Tatsache, dass in der Kommunikation mit Indern und Inderinnen das Wort ,Nein' so gut wie nie vorkommt, als ein Schwerpunktbereich der Verständigung. Auf Fragen und Aufgaben hin werde stets mit Zustimmung wie: ,Ja, Jawohl, Natürlich, Gewiss' reagiert. Auch die Gestik bleibe unklar, da es kein - den Deutschen vertrautes - Schütteln des Kopfes gibt, sondern ein Wiegen, das mehr wie eine Zustimmung als eine Verneinung anmutet. „Sie bekommen sehr leicht immer eine positive Antwort“ 17 u.a.]. Das führt zu einer mehr oder minder großen Unsicherheit, wie diese Zustimmung verstanden werden kann. Es muss davon ausgegangen werden, dass das ,Ja' nicht immer uneingeschränkt gegeben wurde, und somit nicht im Sinne einer Zustimmung reagiert wird. Sehr häufig werden unliebsame Überraschungen erlebt, wenn Aufträge nicht erfüllt wurden, Anfragen nicht bearbeitet, eben weil das ,Ja' kein wirkliches ,Ja' war. Mit der Zeit lasse sich ein Gespür für verschiedene Nuancen des ,Ja' entwickeln, das eine Ahnung von möglichen Varianten, aber keine Sicherheit gibt, was tatsächlich dahinter stehe. Die Interviewten haben von dieser „,typisch indischen Eigenart, nicht ,Nein’ zu sagen“ bereits im Interkulturellen Training gehört, erleben aber die direkte Konfrontation und die Notwendigkeit damit umgehen zu müssen, dennoch als Herausforderung. Es ist nicht nur die eindeutige Verwendung von ,Ja' und ,Nein', die vermisst wird. Die indischen Gesprächspartner und -partnerinnen drücken sich vielfach indirekt und auf eine Weise aus, dass man nicht genau wissen könne, was genau es heißt. Es bleibt vieles im Unklaren, vage Formulierungen lassen mehrere Deutungen und Schlüsse zu. Wenn etwas nicht verstanden wurde, wird nicht rückgefragt. Es komme vielfach keine andere als die Antwort: „Ja“ oder ein Wiegen des Kopfes. Dementsprechend könnten kaum konstruktiv kontroverse inhaltliche Gespräche und Diskussionen entstehen, vielmehr begegne einem widerstandsloses, kritikloses Hinnehmen des Gesagten; keine Anzeichen von eigener Stellungnahme dazu. „Kritisch Sein ist ... ein sehr limitiertes Gut“ [6]. Über gezieltes Nachfragen lasse sich u. U. klären, was wirklich verstanden wurde, und besonders, wenn man um eine Wiederholung mit eigenen Worten bittet. Doch auch dann bleibt abzuwarten, was in Taten umgesetzt wird, und was gesagt wurde, nur weil man weiß, dass es erwartet wird [16, 18 u.a.].

Diese Ungewissheit zwingt zunächst abzuwarten, was verstanden wurde und wie darauf reagiert wird, und macht zugleich eine straffe Kontrolle unerlässlich, Tracking und Monitoring werden zu zentralen Notwendigkeiten [8, 19]. Aufträge und Aufgaben müssten immer wiederholt werden, da nach einmaliger Erwähnung in aller Regel nichts geschähe [2, 3 u.a.]. Bewährt habe sich ein „häppchen - bzw. portionsweises" Übermitteln von Aufgaben [16, 18]. Auch dann noch gelte es, zeitnah und immer wieder zu kontrollieren, was tatsächlich erledigt wird. Verant- 
wortung werde nur übernommen in Verbindung mit Monitoring. Es werde erwartet, dass man über die Schulter schaue, überwache und kontrolliere, womit man sich in Deutschland auf den Schlips getreten fühlte [19]. Es sei ein komplettes Umdenken erforderlich und sei der Situation zu Hause mit Kindern vergleichbar, wo immer nachgehalten und erinnert werden müsse: mach mal dies, mach mal jenes, schalte das Licht aus, putze die Zähne [19]. Alle Interviewten haben schnell erkannt, dass Kontrolle notwendig sei, was nicht bedeutet, dass sie sich daran gewöhnen können. Zur Kontrolle und Überwachung dessen, was die Mitarbeiter tun, gehöre ebenso unerlässlich die Dokumentation, weil sonst die Gefahr bestehe, dass die Entwicklung, der Prozess einer Sache aus dem Auge verloren werde und wieder von vorn angefangen werden müsse - mit der Argumentation und Erläuterung [13]. Auch da gelte es „dran“ zu bleiben, da alles Schriftliche von Indern mit groBer Hochachtung betrachtet und als eine Form der Festlegung gern vermieden werde $[13,17,18]$.

Inder werden in der wissenschaftlichen Literatur als „Homo Hierarchicus“،22 beschrieben und auch den Interviewten erscheint es, als sei der „Hierarchiebezug...fast genetisch verankert“ [6]. Es gäbe sehr viele hierarchisch geordnete Ebenen, die letztlich Verantwortungsbereiche eher verwischen als klarstellen. Die im westlichen Führungsstil implizierte Delegation von Aufgaben an MitarbeiterInnen, die diese in eigener Verantwortung zu erledigen haben, sei in Indien unbekannt [4, $6,7]$. Letztendlich habe der oberste Chef alle Verantwortung; auch kleine, unbedeutende Fragen müssten von ihm beantwortet werden; er habe alles abzusegnen $[2,6,7]$. Das mache es dem Chef mitunter schwer, sich auf wichtige oder auch inhaltliche Arbeiten zu konzentrieren. Ein partizipativer Führungsstil werde mit großem Befremden wie auch mit Verweigerung, Aufsässigkeit oder Maßlosigkeit beantwortet. So sah sich mancher Interviewte entgegen seiner Veranlagung und Überzeugung zu autoritärem Verhalten gezwungen, um als Chef ernst- und wahrgenommen $\mathrm{zu}$ werden $[1,2,3,6,16]$ oder auch sich über lautes gestikulierendes Sprechen Gehör verschaffen zu müssen, denn ruhige, sachliche Gespräche erreichten nicht annähernd solche Wirksamkeit [1, 2, 6, 11]. „Ich degradiere mich gar, wenn ich mich auf gleiche Linie stelle..., dann passiert gar nichts“ [3, vgl. auch 16]. Die hierarchischen Ebenen seien sehr weit verzweigt, so dass es bei der Informationsweitergabe oft zu Problemen komme. Informationen würden verwaschen und verändert oder gingen einfach verloren. Es sei nicht selbstverständlich, alle nötigen Informationen weiter zu leiten an diejenigen, die sie brauchen $[1,2,3,6,12,16]$. Vielmals müssten sie erbettelt werden. Dabei habe es sich als günstig erwiesen, sich hilfsbedürftig zu zeigen. „I'm a bit lost; I dont know, how to decide now; please can you update me on that" [3]; und auch dann werden Informationen gefiltert weitergegeben $[6,12]$.

\footnotetext{
${ }^{22}$ Siehe Kakar, Sudhir; Kakar, Katharina: Die Inder, Porträt einer Gesellschaft, München: C.H.Beck 2006, S.26.
} 
Teamarbeit ist kaum vorhanden und schwer einzuführen [6, 13, 16, 17, 18, 19]. Hingegen wird das Egoistentum als sehr ausgeprägt erlebt [1, 6, 19]. „Die Personen wollen sich alle profilieren. Wenn diese Person irgendetwas im Kopf hat, dann macht sie das - es wird nicht thematisiert, diskutiert; es geht nur um persönliche Profilierung. Es wird nicht inhaltlich gearbeitet.“ (1). Das eigene Know How werde geschützt, indem man es für sich behalte [17]. Einem anderen, gerade bedürftigen, Arbeitsteam zu helfen, sei nicht selbstverständlich und müsse von oben angeordnet werden [17]. Das Verhalten erscheint als „Selbstsüchtigkeit“ [1, 4, 6, 16], gepaart mit ,unglaublicher Arroganz“, wenn beispielsweise ein unredlicher Mitarbeiter dem Chef mit Strafverfolgung drohe [6]. Die Ignoranz internationaler Forschungen und das Bestehen auf - veralteten - indischen Forschungsergebnissen zeugen von: „ein bisschen zu viel Selbstbewusstsein“ [6], „ein bisschen zu viel Chauvinismus" [6]. Superlative würden inflationär verwendet, was bedeutet, dass z.B. Arbeitsberichte kritisch gelesen werden müssten, zu oft werde hemmungslos beschönigt. „Ich habe in keinem Land Leute gefunden, die so perfekt von der Katastrophe als Erfolg berichten können.“ [6]. In Lebensläufen und Bewerbungen sei so manche Selbstüberschätzung auszumachen bis hin zur Fälschung von Zeugnissen $[16,17]$.

Neben der Tatsache des Nicht-Nein-Sagen-Könnens und NichtWidersprechens fällt auf, dass an sich viel geredet und debattiert werde [2, 3, 8]. „Inder diskutieren ganz gern und nicht unbedingt zielführend““ $[2,17]$. Sie „lieben die Auseinandersetzung...mit...mit komplexer Materie, Inder lieben einfach auch...Probleme... Wenn man den Inder zu schnell auf den Punkt, wenn man Inder zu schnell reduzieren will, also auf das Ergebnis reduzieren will, dann sind die ganz enttäuscht" [5]. Es werden viel und gern Geschichten erzählt [1, 18], Tatsachen ausgeschmückt und Informationen verschwiegen oder verspätet gesagt [1, 2, 3, 4, 5, 6, 7, 12, 13, 14]. „Unehrlichkeit, Lüge ist nicht sozial verdammt“ [5]. Absprachen würden ins Gegenteil verdreht [3], was Situationen komplett verkehrt und das Gegenüber in Rechtfertigungsdruck bringt [3,6]. Unverbindlichkeit sei normal. Man müsse nicht verlässlich sein, alles sei immer neu verhandelbar [1, 2]. Es gäbe stets Begründungen für Verspätungen und Ausreden für Nicht-Erledigtes. Man könne nicht das Einhalten von Commitments erwarten [13]. Termine würden nicht als verbindlich angesehen. Man tue gut daran, immer einen zeitlichen Puffer einzuplanen, insbesondere wenn Gewerke von der Fertigstellung anderer abhängen [18]. Der andere Umgang mit Zeit erfordere manche unerwünschte und zu ausgiebige Wartezeit [7, 9, 15], die der westlichen Vorstellung, nämlich Zeit effektiv nutzen zu müssen, heftig zusetzt. Hinzukommt, dass alle Vorgänge in Indien - aus verschiedensten Gründen - erheblich länger dauern, was das Thema Zeit und Termine, vor allem in der Planung mit einem deutschen Head Office, brisant werden lassen könne [13, 16, 17, 18]. Nicht selten kämen indische Mitarbeiter schlecht vorbereitet zu Besprechungen [4] und ohnedies erheblich verspätet [13, 17, 18]. Es wird wenig Effizienz [4] und geringe Professionalität [6, 11, 18, 19] beklagt. 
$\mathrm{Zu}$ bewundern sei die Improvisationskunst der Inder: ,wenn man in allerletzter Minute oder in der Minus-neunten-Minute versucht, auf einmal in der Nacht Rom zu versetzen“ [18]. Es grenze manchmal an ein Wunder, dass Termine doch noch geschafft würden [9, 18]. Inder seien absolut flexibel. Wohl dadurch, dass Beruf und Privat weniger getrennt werde, seien z.B. Überstunden überhaupt kein Problem, ob am Abend, am Wochenende, oder auch aus dem Urlaub heraus zu telefonieren. „Es ist wohl auch ein Pflichtbewusstsein vorhanden - das ist paradox, aber es ist so“ [19]. Die Leute in Indien seien sehr kreativ, „weil sie sich durch die ganzen schwierigen Umstände durchkämpfen müssen“ [19]. In der Technik seien sie wirklich Spitze - mit hoher Effizienz, technisch brillant. Sie fänden einmalige Lösungen. Ein IT-Programm könne groß oder schlank geschrieben werden und den gleichen Zweck erfüllen. Wenn Kollegen ins Ausland gerufen würden, um technische Probleme mit zu lösen, seien sie ohne Einarbeitung sehr schnell in der Lage zu begreifen und zu verstehen. Manche seien richtige Künstler [17]. Das sei ein Unterschied zum eher beharrlichen Denken der Deutschen, die sich manchmal verrennen, nur um eine gewisse Linie zu fahren. Auch wenn das mitunter nötig sei, um Chaos zu vermeiden [19]. Die Inder seien sehr beweglich im Denken [19], jedoch bestehe zunächst keine Aufgeschlossenheit für Neues [4]; sie hielten lieber an Altbewährtem fest. Inder „denken ja passiv, akzeptieren so wie es ist und denken nicht, dass man es verändern kann - weil es vielleicht hier auch nicht so veränderbar ist" [10].

Die Inder werden an sich als mitteilungsfreudig, offen und kooperationsbereit erlebt. Eines falle weiterhin auf: „totaler support! Der Inder ist immer sofort da, wenn man Hilfe braucht - immer, egal was es ist. Der Inder hilft sofort. Ob er letztendlich richtig gut geholfen hat, das ist egal... Manchmal fehlte so ein bisschen die Ruhe und die Geduld es richtig zu erklären. Immer wieder gibt es auch Kommunikationsschwierigkeiten, also, dass die das in meinen Augen nicht richtig erklären können, meine Fragen nicht richtig beantworten können. Ja, sie verstehen es nicht, oder wollen es nicht, oder denken einfach anders“" [2, vgl. auch 16, 19]. Es wird eine „Unfähigkeit zu vernetztem oder strukturiertem Denken“ wahrgenommen $[4,6,13,16]$. Allerdings könnten „die Inder...lateral denken“ [10], d.h. Multitasking, vieles gleichzeitig tun [14]. Das führt zu zwiespältigen Gefühlen bei Deutschen, die fürchten, dass dann nicht wirklich konzentriert gearbeitet werde, zugleich aber auch bewundern, was alles parallel bedacht werden könne - mit bis zu 20 geöffneten Fenster auf dem PC arbeiten Mitarbeiter parallel an 3 Programmen [17].

Es wird bemerkt, dass keine Prioritäten gesetzt werden, sondern das Zuletztgekommene als erstes getan werde [2, 3]. Ähnlich wie im Geschäft der Zuletztgekommene zuerst behandelt werde, werde auch bei dienstlichen Besprechungen eine gerade erscheinende Mail zum sofortigen Besprechungspunkt, egal worüber gerade beraten wurde. 
Es werde schuldorientiert vorgegangen, was bedeute, dass nicht weiter gearbeitet werde, bevor nicht ein Schuldiger für etwas Schiefgelaufenes gefunden sei [16, 17, 18, 19].

Ähnlich wie in früheren Zeiten, als es um ein „survival of the day“ ging, werde wenig vorausschauend gedacht. Das Morgen oder gar Übermorgen werde wenig bis nicht bedacht; es gebe kaum langfristige Planungen [1, 2, 3, 7 u.a.]; der Moment, das Jetzt, zähle - so sehr, dass für eine gute Atmosphäre wichtige, aber unliebsame Informationen zunächst verschwiegen würden. Es zähle das momentane Wohlergehen, der schnelle Erfolg, was u.a. zur so genannten Attrition führe und letztlich u.a. auch die Gehälter in die Höhe treibe.

Die Inder werden als Traumtänzer erlebt: idealistisch, phantasievoll, verträumt, optimistisch, die die Augen gern vor Negativem und Schwierigkeiten verschließen. Das gedankliche Fliegen erscheint als bodenloser Höhenflug ohne Bezug zur Realität [2, 5, 6 u.a.].

Kritik sei absolut tabu [2, 3, 12, 13, 14] und kann - wie oben erwähnt - zum Suizid führen [18]. Stets nur unter 4 Augen und dann auch abgefedert in Lob für anderes, ließen sich kritische Punkte äußern. Oftmals werde die Verbindung zu den eigenen Fehlern nicht gesehen, wenn es z.B. keine Gehaltserhöhung geben könne [6]. Es habe sich bewährt, Kritik mit einem Lächeln vorzutragen, damit es nicht zu hart treffe [14]. Inder seien nicht nachtragend. Es dauere nicht lange, bis nach einer heftigen Auseinandersetzung die beiden Parteien wieder friedlich und unbelastet miteinander plaudern [2, 3, 9].

Die Wirksamkeit des Kastenwesens hat einige Interviewte überrascht in seiner z. T. untergründigen, aber noch immer Selbstverständlichkeit. So würden nur Arbeitsaufgaben erledigt, die dem jeweiligen Kastenrang entsprächen, wonach es z.B. unter der Würde sei, ein Papier aufzuheben oder jemandem aus niederer Kaste zu rapportieren $[5,6,16]$. Mitarbeiter dazu zu erziehen, stoße auf Widerstände, nehme man doch den „Oberen“ ein Privileg weg [6]. Kaste und sozialer Status haben nach wie vor Bedeutung in Indien. In Smalltalk und höflichen Wortwechseln wie auch über ganz direktes Ausfragen wichtiger Eckdaten wie Herkunft und Wohnort, werde zunächst geklärt, wer das Gegenüber ist $[3,5,6,14,16]$.

Der Familie komme eine ungleich größere Bedeutung in Indien zu; nicht selten sei die Familie wichtiger als der Job. Familiäre Gründe, Verwandtenbesuche, Erkrankungen etc. seien selbstverständliche Ursachen für Zuspätkommen und Fernbleiben von der Arbeit [19].

Das Leben werde viel mehr in seiner Ganzheit wahrgenommen, Privat und Beruf nicht getrennt, sondern vermischt - getragen von der Familie, der Religion, deren Rituale den Alltag strukturieren. „Hier in Indien ist so vieles mystisch, religiös und all so'n Kram. Ich hatte mal eine Situation am Anfang, die war mir unangenehm: da ist mein Managing Direktor in seine Cabin gegangen, in sein Büro. Und ich wollte ihm eilig etwas mitteilen und bin ihm direkt hinterher gegangen - nach 2 Minuten, und stürzte da auch hinein. Und da kam ich so mitten in seine Puja, also er stand dann so vor dem Bild und betete das Bild an - das macht er jeden Morgen 
- da war ich so richtig überrascht; das habe ich überhaupt nicht erwartet - also gerade der Managing Direktor, ein total internationaler Mensch. Bei den Indern ist es so, wenn die so international denken, vergessen die plötzlich all ihre Sachen, die sie hier gepflegt haben, aber er legt da weiterhin Wert drauf, das werde ich nicht vergessen, dieses Erlebnis“ [2]. Die Religiosität wird als Alibi erlebt, wenn beispielsweise Laxmi, die „Geldgöttin“, die „Raffgier“ absegne [12]. Glaubensgeschichten wie zum Verabreichen des Gangeswasser oder zur Bedeutung des Pfau als heiliges Tier bleiben suspekt und unverständlich, zu extrem [4, 5]. Die Bedeutung eines Tempels als Besinnungsstätte erschließt sich einem selbst [4], und deutet damit auf die Notwendigkeit von Refugien der Ruhe, Stille und Andacht. Es wird als großer Vorteil des Lebens in Indien - vor allem auch im Unterschied zu Deutschland - gesehen, dass es vollkommen selbstverständlich sei, sich zur Meditation in einen Ashram zurückzuziehen. Es werde eine große Toleranz empfunden, sein Leben nach eigenen Prioritäten gestalten zu können. So könne man sicher sein, beispielsweise mit einem Leben, das nicht ausschließlich der Arbeit gewidmet sei, nicht schief angesehen zu werden [20].

Hinsichtlich der aktuell boomenden Entwicklung Indiens und seiner Stellung auf dem Weltmarkt, wird es mitunter schwer, die alltäglichen Erlebnisse einzuordnen. Arroganz, Selbstbewusstsein, ein bisschen zu viel Chauvinismus ,verschließen die Augen für das andere, für den Rest der Welt. Das ist sehr gefährlich“ [6]. Zurzeit geschieht es nämlich, dass „die Leute sich besser verkaufen können, als dann irgendwann wieder die Substanz dahinter ist... D.h. also die Dynamik, das Selbstbewusstsein der Inder, hat sich völlig umgedreht, völlig umgedreht" [8]. Die Gegensätze sind so groß; ,,es gibt viele erfolgreiche Firmen, aber im alltäglichen Leben denke ich: die schaffen das nie“ [12]. In China beflügle die Infrastruktur die Wirtschaft, in Indien sei es umgekehrt [19]. Die jetzige politische Situation sei schlimm; Reformen und Geld würden blockiert. „Geld haben, ist eine Sache, mit dem Geld etwas zu bewerkstelligen, ist eine andere Sache“ [19].

Die Schilderungen der Interviewten sind mit all dem angefüllt, was sich von dem Gewohnten abhebt, was dazu führte, dass Vertrautes nur kurz erwähnt wurde, auch wenn es in Indien ebenso anzutreffen ist. Da das den Gesamteindruck verfälschen könnte, ist hier zumindest zu erwähnen, dass das Gegensätzliche des Beschriebenen wie Pünktlichkeit, Professionalität, Fachleute, Spezialistentum u.ä. auch zu finden sind. Dies nahm in den Interviews weniger Raum ein, weil es für die Interviewten kein Umdenken im eigenen Verhalten erforderte. Es führte allerdings zu Irritationen, insofern als man nie wissen könne, womit zu rechnen sei, dass es immer - positive wie negative - Überraschungen geben könne [2, 3 u.a.].

Insgesamt wird mit den hier zusammengetragenen Schilderungen kein Anspruch auf Vollständigkeit erhoben. Die Sammlung der Eindrücke und Wahrnehmungen der Interviewten ist ausschließlich phänomengeleitet. 
Es soll nun der Blick auf die Interviewten fokussiert werden, wie sie auf ihre Beobachtungen und Wahrnehmungen reagieren, wie sie damit umgehen und sich dabei fühlen. ${ }^{23}$

Es sollte eine Voraussetzung sein, die Zu-Hause-Brille abzusetzen und brauche die „Bereitschaft: ich kann nicht alles machen wie zu Hause“ [19]. Am besten sei es, ohne feste Vorstellungen zu kommen, offen zu sein und sich überraschen lassen und auf die Erfahrung einzulassen [4, 9, 15]. Das brauche Überzeugung und Begeisterung [15]. Es gehe darum, das kreative Chaos zu beherrschen, sich stets auf wechselnde, neue Situationen einzustellen, d.h. flexibel reagieren zu können [1, $2,3,6,7,8,12,13,16,17,18]$. Das sind sehr hohe Anforderungen, die einen mitunter an den Rand des Verständnisses bringen können. An keinen, noch so guten, Plan könne man sich halten; man müsse stets bereit sein, ihn umzuwerfen $[1,2,3$, 6, 11, 12, 16, 18]. Man brauche die Einstellung: jedes Problem wird gelöst, nur nicht in einer bestimmten Zeit [16, 18]. Selten habe man das Gefühl, eine Situation im Griff zu haben [1, 2, 3, 7, 12, 13, 16, 18]. „Ganz unangenehm ist es gegenüber Kunden: da kriegt man dann Informationen von den Kunden, die einem die eigenen Mitarbeiter hätten sagen müssen. Da ist die Unsicherheit ganz groß. Man hat sich gegenüber den Kunden aus dem Fenster gehangen - und dann weiß der Kunde mehr, als man selbst. Da wird man ja als Manager unglaubwürdig. Es ist ein permanenter Zustand der Unsicherheit! Das ist wirklich anders als in Deutschland: da ist rechts rechts, und links ist links. Hier muss man immer mit irgendetwas rechnen, was man nicht erfährt. Und vieles stimmt einfach nicht. Es ist schwer, eine vertrauensvolle Zusammenarbeit aufzubauen." [12]

Dieser permanente Zustand der Unsicherheit hinterlasse ein Gefühl der Abhängigkeit und mitunter auch der Hilflosigkeit, wenn vertraute Reaktionsformen nicht greifen [12] und z.B. eine Bestrafung die sofortige Kündigung oder zumindest totale Arbeitsverweigerung zur Folge hat $[12,18]$. „Man müsse ihn (den Bediensteten) wie ein rohes Ei behandeln. Man versuche immer wieder entgegen zu kommen. Im Büro sei es etwas einfacher. „Die sind gewöhnt, stringent zu arbeiten. Aber auch in der Firma gilt: wenn man jemanden zu hart anpackt, kündigt er" [12]. „Man muss abwägen, wo man mehr Nachteile zu erwarten habe, wenn man irgendwelche Konsequenzen ziehen möchte. In aller Regel gibt man nach und braust besser nicht auf; man gibt klein bei“ [12; vgl. auch 1, 2, 3, 18].

Das Interkulturelle Training, das viele Interviewte vor ihrer Entsendung nach Indien absolviert haben, sei schon eine Basis und helfe vor allem, im Nachhinein für ein Geschehen Erklärungen zu finden. „Das hilft, dass man nicht an sich selbst zweifelt, dass man nicht überkritisch sein muss mit sich selbst. Man fragt sich ja oft, ob man selbst Schuld ist" $[9,12]$.

Es brauche unendliche Geduld [1, 2, 3, 6, 7, 12 u.a.] und doch sei es kaum zu verhindern, dass man hin und wieder zu Wutanfällen hingerissen werde, obwohl

\footnotetext{
${ }^{23}$ Es kann zu Wiederholungen vom ersten Teil kommen, die sich hier aus anderem Blickwinkel erschließen und insofern die Aussagen des ersten Teiles ergänzen.
} 
man eigentlich ein friedfertiger Mensch sei $[1,2,6,7,10,12,13,14]$. Und dann bleibe man drauf sitzen. Es interessiere keinen - und es ändere nichts. Beanstandungen liefen ins Leere; das nächste Mal laufe es wieder genauso [1, 2, 7]. Anders sei es mit dem - u.U. gegen die eigene Überzeugung - Zeigen eines autoritären Führungsstils, dem deutlichen, lauten Zeigen von Ärger z.B., worauf klar und gehorsam reagiert werde, wohingegen ein ruhiges Erbitten keine Wirkung zeige [1, 2, $6,7,12,13,14,16]$. Ein Verwischen von Hierarchien oder Rängen wie durch das Selbstanfassen von Gepäck oder gar Müll, oder etwas selbst zu putzen, habe in der Regel Verwirrung mitunter auch Verachtung zur Folge und den Verlust von Respekt durch Bedienstete $[1,12,16]$.

„Man braucht Nerven. Man muss immer wieder selbstmotiviert und nachhaltig hintendran bleiben. Man muss - gegen alle Unbilden - seine Linie beibehalten, sonst wird man verrückt oder genauso“ [12]. „Wenn Sie keine intrinsische Motivation haben, dann wird es schwierig." [8]. Neben einer hohen Stressresistenz brauche man eine ausgeprägte Kompromissbereitschaft. Man müsse sehen lernen, was gut laufe $[2,9,15,18]$. Man müsse bereit sein, Kompromisse einzugehen, und mit diesen auch glücklich sein können [5].

Es wird zu einer - erleichternden - Erkenntnis: „man kann diese Kultur nicht rational erfassen“ [6]. Auf sein Bauchgefühl hörend, lasse sich vieles klarer sehen und erkennen und letztlich auch entschiedener handeln [6]. Trotz gegenteiliger Stellungnahmen anderer konnte z.B. ein Interviewter auf diese Weise einen Betrüger der Firma enttarnen [6]. Mit ,,achtsamer Intuition“ ließen sich Katastrophen schneller erkennen und unter Umständen auch vermeiden [11]. Dennoch erfasse einen immer mal wieder ein ,resignativer Missmut“ [11]. Aber man dürfe nicht moralisch urteilen, brauche neben Stressresistenz, unendlicher Geduld und Kompromissbereitschaft, starke Nerven und beobachtende Ruhe und Offenheit für Alternativen [1, 3, 4, 5, 6, 7 u.a.].

Alles bewege sich in Extremen, Ups and Downs, entweder alles laufe von allein oder alles stürze über einem zusammen [2, 3, 13, 16, 19].

Es brauche den Willen, anderen zu helfen und gleichzeitig sich selbst helfen zu lassen [15], um sich für die Erfahrungen in Indien, den anderen Dimensionen von Verhalten und Erleben, dem Menschlichen überhaupt, öffnen zu können. So biete der idealistische Zugang der Inder überraschende, ungewohnte Freiheiten: zu phantasieren, einfach auszuprobieren, Ideen zu verfolgen. Das ist zunächst verunsichernd, aber letztlich ein Freiraum, wohltuend und befreiend. Es blockieren keine Gesetze, Regeln und ,Aber' wie aus Deutschland gewohnt [2, 3, 7, 10, 11, 15]. Auch die Fähigkeit „lateral“ denken zu können, wie man sie bei den Indern erlebe, reize und werde zu erproben versucht [14]. „Ohne Zeitplan, ohne Vorgabe, ohne Druck...ohne Beschränkung" habe er, sagt ein Interviewpartner, in Ruhe das Land und seine Zusammenhänge erschnüffelt, um gemeinsam mit den Indern ein Konzept zu erarbeiten [5] - und dabei erkannt: „Indien ist eines der wenigen Länder der Welt, das einzige, was ich kenne, in dem man utopische Ziele setzen kann. Und diese utopischen Ziele wirken nicht als Bremsen, sondern als Motivator oder Inspi- 
rator“. Diese Erkenntnis habe viel zum Erfolg des Unternehmens beigetragen, schließlich sei die Motivation der Mitarbeiter das wichtigste Gut. „Inder lieben es, in utopische Ziele eingebunden zu werden, die sie selber mitbestimmen müssen.“ Es gehe darum, utopische Ziele zu setzen, die dann in praktikable chunks heruntergebrochen werden müssten“ [5]. Das Aktionsfeld sei dauernd neu zu bestimmen, inhaltlich und im Vor- und Zurückgehen [5].

Inder seien wissbegierig und neugierig, was einen Interviewten z.B. veranlasst habe eine anstehende Revision aus Deutschland in ,Best Practices Transfer' umzubenennen, und damit ein Schlüsselerlebnis im Zusammenbringen beider Kulturen zu kreieren. Nur die deutschen Revisoren hätten Schwierigkeiten gehabt, sich als Lehrer zu verstehen [5].

Die Interviewten haben gelernt, die in Indien vollkommen akzeptierten, wenn nicht gar selbstverständlichen, Verhaltensweisen wie ausweichend und ungenau zu antworten oder Verantwortung weiter zu schieben, im Bedarfsfall auch selbst anzuwenden. „Ich bin oft zu ehrlich, und das ist dann manchmal schon dumm. Man macht es sich nur unnötig schwer. Hier macht man sich das Leben sauschwer, wenn man immer genau das sagt, was man denkt. Man stößt andere Leute vor den Kopf“ [3]. Die „oft belästerte unverbindliche Art hat auch etwas...nicht so Konfrontatives, ...Angenehmes an sich. Man kann also relativ leicht Small Talk machen. Man muss nur immer wissen, ab wann man etwas Verbindliches braucht" [1, $2,3,5,6,11,14,15]$. „Die Verhandelbarkeit von letztlich allem ist eine ganz indische Eigenart" [5]. Daher lasse der Interviewte sehr lange alles offen im - sehr langen - Entscheidungsfindungsprozess. Wenn aber etwas festgelegt wurde, dann gäbe es keine Diskussion, keine Änderung mehr [5].

„Erwachsene hier sind nicht im wirklichen Sinne erwachsen, so wie man das im Westen kennt, die sind noch sehr...die hängen an der Familie wie Kinder an den Eltern und suchen einen Ersatz dann im Arbeitsplatz...eine Onkel- oder Vaterfigur" [19]. In der Firma werde man besonders als Chef in einer Vater- oder Mutterrolle und einer entsprechenden Verpflichtung gesehen, d.h. es erfordere unendlich mehr Zeit, sich um zwischenmenschliche Belange zu kümmern, Beziehungen zu schlichten, Konflikte zu lösen, häuslichen und privaten Problemen Gehör zu schenken. „Das wäre in Deutschland kein Thema, wofür hier die Arbeit stehen bleibt" [19]. Dem betreuenden Moment bei der Arbeit komme eine große Bedeutung zu. Manchmal fühle er sich wie ein Kindergärtner, formuliert ein Interviewter [6]. Es gehe darum, der Vater-, Mutter-, Familienrolle, in der man durch die berufliche Position gesehen werde, nach zu kommen, zuzuhören, Vertrauen zu schenken, souverän, geduldig, nachgiebig und bestimmend, je nach dem mit oder ohne erhobenem Zeigefinger zu vermitteln, wie etwas zu machen sei $[4,5,9,11$, 14, 15, 19], wie z.B. indische Gesprächspartner an Sachlichkeit heran zu führen [18]. Das Tabu von Kritik beherzigend dennoch mit Lob und Tadel oder auch Drohung, Motivation anzustacheln und Interesse oder gar Träume zu wecken [2, 4, 5, 6, 16, 18]. Überschaubare Aufgaben, Teilziele setzen und dabei das große Ziel nicht aus dem Auge verlieren. Es gelte, im Blick zu haben, wohin etwas hinauslau- 
fen solle und so zu dirigieren, dass das auch am Ende herauskomme. „Ich bin nie der, der entscheidet, sondern ich versuche immer, dass die anderen die Entscheidungen machen, die ich vorher weiß, die kommen müssen. Also ich weiß, was ich will“" [9].

Es sei eine Kunst ein Team zusammenzustellen, das zusammenarbeiten kann $[6,13,16,17,18,19]$. Die harte Tour bringe nichts, aber auch mit Freundlichkeit komme man nicht weit $[1,2,3,5,6,7,12,13,16$ u.a.].

Der oben beschriebenen Kontrolle inkl. Dokumentation komme eine unerlässliche Bedeutung zu. Es helfe, wie oben gesagt, sehr genau auf den Zahn zu fühlen, was verstanden wurde, in jeder Hinsicht ganz konkret rückzufragen und es noch einmal formulieren zu lassen mit eigenen Worten. Ein Auge-in-Auge-Gespräch sei immer vorzuziehen $[3,4,6,7,12,13]$, da dies Gestik und Mimik vermittle und so zum besseren Verständnis beitrage. Es wird empfunden, dass die non-verbale Kommunikation in Indien wichtiger ist als die verbale - umgekehrt zum Verständnis in Deutschland, wo mehr Wert auf das Wort als auf die Mimik gelegt werde [14]. „,Wenn einer sagt: ich komme morgen um 5, dann kann es auch sein, dass er um 6 kommt. Insofern wird das Wort hier nicht so auf die Goldwaage gelegt wie bei uns, ne. Aber wenn einer lächelt, dann heißt das: der ist o.k. Der haut mir jetzt nicht gleich eine runter. Vielleicht vertraut man eher diesen nonverbalen Signalen“ [14]. Es ist ,eine andere Art der Kommunikation, die ich sehr schätze - mit menschlicher Wärme und Zuneigung und Geben - das ist irgendwie präsent hier, im Gestus, in der Mimik. Der Westen ist ja doch mehr kopforientiert“" [10]. Insgesamt sei es nötig, sehr viel stärker auf sein Gegenüber einzugehen [18], wenn man den anderen öffnen wolle für gemeinsame Arbeitsziele oder auch um kritische Punkte ansprechen zu können. Dies erfordere sehr viel mehr Zeit als man es aus Deutschland gewohnt sei, wo z.B. bei Besprechungen einfach Fakten abgearbeitet werden könnten, hier aber auf eventuelle Empfindlichkeiten Rücksicht genommen werden müsse. Dazu gehöre auch ein intensiveres Eingehen auf zwischenmenschliche Belange, da sonst die Arbeit liegen bleibe [19].

Entgegen der Unnachgiebigkeit, mit der gesetzte Ziele in der Regel in Deutschland verfolgt werden, müsse man in Indien auch in der Lage sein, etwas liegen zu lassen, was gerade nicht gelöst werden könne und dies gegebenenfalls später wieder anzufassen. „In diesem Riesenland ändert sich ja auch immer dauernd alles,...die Parameter verschieben sich." Mitunter zeige sich am nächsten Tag eine andere Konstellation, und das Ziel falle einem förmlich in den Schoß. „Nee, durchbeißen, das geht hier nicht" [5]. So ist es geradezu gesundheitsschädigend, wenn man sich zu viel auflade. „Wenn ich mir zu viel vornehme, dann erschlägt mich das" [5]. Wenn man zu sehr ausgebrannt sei, werde das Immunsystem schwächer, und schon picke man sich aus dem unglaublichen Angebot irgendwelche Geschichten auf und werde schlichtweg krank. Entsprechend problematisch sei es auch, gefühlsmäßig schlecht drauf zu sein: „,wenn man mürrisch ist in Indien, dann ist schon alles verloren... Wenn Sie in Indien beim Arbeiten schlechte Laune haben, sind sie noch nicht mal 50\% produktiv“" [5]. 
Erstaunt haben Interviewte bei Besuchen in Deutschland eine höhere Toleranzschwelle und Gelassenheit an sich beobachtet [7], wie auch das glatte Gegenteil nämlich total aufzubrausen - wie in Indien gelernt - aus Panik, dass etwas nicht wie vereinbart gemacht werde [2].

Ein Aspekt, der sich von Indern und Inderinnen lernen lasse, sei das Leben im Hier und Jetzt, z.B. das Abschalten-Können nach der Arbeit, wie auch die Fähigkeit, zufrieden zu sein - trotz sich häufender oder offensichtlich schwerwiegender Probleme; aus dem, wie sich das Leben zeige, das Beste zu machen $[1,2$, 3, 5, 6, 9, $10,11,14,15,16,17]$. Nicht selten beginne man das Leben daheim in Deutschland mehr wert zu schätzen $[7,12,13,16,19]$.

\section{Literatur}

Boesch, Ernst E.: Das Fremde und das Eigene, -in Thomas, A. (Hrsg.): Psychologie interkulturellen Handelns, Göttingen: Hogrefe 1996

Caspar-Hehne, Hiltraud: Deutsch-amerikanische Alltagskommunikation. Zur Beziehungsarbeit in interkulturellen Gesprächen, Tübingen: Max Niemeyer Verlag 2006

Erdheim, Mario: Psychoanalyse und Unbewusstheit in der Kultur, Frankfurt/M.: Suhrkamp 1988

Freud, Anna: Das Ich und die Abwehrmechanismen, Frankfurt/M.: Fischer Taschenbuch 1984

Freud, Sigmund (1930): Das Unbehagen in der Kultur, -in: Freud, Sigmund: Gesammelte Werke, Bd. IX, Frankfurt/M.: Fischer 1997

Grünewald, Stephan: Der Psychologe als Kulturforscher, -in: Zwischenschritte, 2/1992

Gupte, Niteen/Müller-Gupte, Anke: Indischer Arbeitsplatz aus deutscher Sicht. Eine Studie in interkultureller Kommunikation, Pune 2008 (CSS Occasional Papers Series 2007-2008, Univ. of Pune)

Heringer, Hans-Jürgen: Interkulturelle Kommunikation. Grundlagen und Konzepte, Tübingen-Basel: Francke 2004

Kakar, Sudhir; Kakar, Katharina: Die Inder. Porträt einer Gesellschaft, München: C.H.Beck 2006

Kühlmann, Torsten; Müller-Jacquier, Bernd (Hrsg.): Deutsche in der Fremde. Assimilation - Abgren zung - Integration, St. Ingbert: Röhrig Universitätsverlag 2007 (Schriften des Instituts für Internationale Kommunikaiton und Auswärtige Kulturarbeit Bayreuth, IIK Bayreuth, Bd. 1) 
Kumbier, Dagmar; Schultz von Thun, Friedemann: Interkulturelle Kommunikation: Methoden, Modelle, Beispiele, Reinbek: Rowohlt 2006

Lenz, Bernd; Lüsebrink, Hans-Jürgen: Fremdheitserfahrung und Fremdheitsdarstellung in okzidentalen Kulturen. Theorieansätze, Medien/Textsorten, Diskursformen, Passau: Richard Rothe 1999

Lüsebrink, Hans-Jürgen: Interkulturelle Kommunikation. Interaktion, Fremdwahrnehmung, Kulturtransfer, Stuttgart: J.B. Metzler 2005

Lüsebrink, Hans-Jürgen (Hg.): Konzepte der Interkulturellen Kommunikation. Theorieansätze und Praxisbezüge in interdisziplinärer Perspektiv, St. Ingbert: Röhrig Universitätsverlag 2004 (Saarbrücker Studien zur Interkulturellen Kommunikation Bd.7)

Maletzke, Gerhard: Interkulturelle Kommunikation. Zur Interaktion zwischen Menschen verschiedener Kulturen, Opladen: Westdeutscher Verlag 1996

Mitterer, Katrin; Mimler, Rosemarie; Thomas, Alexander: Beruflich in Indien. Trainingsprogramm für Manager, Fach-und Führungskeäfte, Göttingen: Vandenhoeck \& Ruprecht 2006

Müller-Gupte, Anke: Deutsche in Bombay, Bewältigungsformen unter Berücksichtigung des Gesundheitsverhaltens. Unveröffentlichte Diplomarbeit im Fach Psychologie an der Universität zu Köln, 1994

Nagera, Humberto: Psychoanalytische Grundbegriffe, Frankfurt/M: Fischer 1989

Parin, Paul: Das Ich und die Anpassungs-Mechanismen, Psyche 6/77, 1977, S.481515

Rothermund, Dietmar: Indien. Aufstieg einer asiatischen Weltmacht, München: C.H. Beck 2008

Salber, Wilhelm: Die Morphologie des seelischen Geschehens, Ratingen: Henn 1965

Schroll-Machl, Sylvia: Die Deutschen - wir Deutsche. Fremdwahrnehmung und Selbstsicht im Berufsleben, Göttingen: Vandenhoeck \& Ruprecht 2007

Straub, Jürgen; Weidemann, Arne; Weidemann, Doris (Hrsg.): Handbuch interkulturelle Kommunikation und Kompeten : Grundbegriffe - Theorie Anwendungsfelder, Stuttgart-Weimar: J.B.Metzler 2007

Thomas, Alexander; Kinast, Eva-Ulrike; Schroll-Machl, Sylvia (Hrsg.): Handbuch Interkulturelle Kommunikation und Kooperation. Band 1: Grundlagen und Praxisfelder, Göttingen: Vandenhoeck \& Ruprecht 2005

Thomas, Alexander; Kammhuber, Stefan; Schroll-Machl, Sylvia (Hrsg.): Handbuch Interkulturelle Kommunikation und Kooperation, Band 2: Länder, Kulturen und interkulturelle Berufstätigkeit, Göttingen: Vandenhoeck \& Ruprecht 2007 
Weidemann, Doris: Interkulturelles Lernen. Erfahrungen mit dem chinesischen $>$ Gesicht $<$ : Deutsche in Taiwan, Bielefeld: transcript 2004

Weimbs, Regina: Ausreisen - Ausreißen? Die biografische Dimension der Ausreisemotivation von Entwicklungshelfern, Unveröffentlichte Diplomarbeit im Fach Psychologie an der Universität zu Köln 1997

WirtschaftsWoche Global, Nr.2, 17.11.2008

Zotz, Volker: Die neue Wirtschaftsmacht am Ganges. Strategien für langfristigen Erfolg in Indien, Heidelberg 2006 



\title{
Globalisation and Cosmopolitan Identities
}

\author{
Pramod Talgeri
}

A few years ago a Pakistani ambassador, while lecturing at the Jawaharlal Nehru University, New Delhi, on the Indo-Pak relations, in a lighter vein remarked that his country could boast of having the birthplace of the first grammarian of the world, Panini, in Pakistan at Attock. Today any Indian can without any resentment observe that this great Sanskrit grammarian, continues to remain a part of the Indian culture, even when the place he was born and lived, is today in Pakistan.

I am not so sure about the Pakistanis appropriating Panini as a part of the Pakistani culture, whereas Nazrul Islam and Iqbal (the spiritual mentor of the foundation of Pakistan) continue to be part of the modern Indian culture. In the Indian context this reveals a peculiar de-linking process of a common cultural heritage and identity from the societal formation and the state form. In this de-linking process, the sense of 'nationality' becomes increasingly blurred and redundant. This process ultimately detaches itself from the ethnically oriented notion of nationality and creates a climate for the political identification with the values of the constitutional state.

But the Nation is the first modern form of collective identity, which however still feeds on projections of its ethnic origin. A modern nation today, therefore, still oscillates between an imagined natural origin of an ethnic nation and juridical construction of a nation of citizens.

There is a kind of cultural symbolism of a 'Nation', which articulates itself in a presumably common ethnic origin, common language, and common history as its unique character of its national spirit. This symbolism produces a sense of imaginary unity and gives to the inhabitants of the same state a concrete sense of be- 
longing. This symbolic construction of a 'people', 'Volk', constitutes a nationstate. ${ }^{1}$

But the historically grown up nation is a reservoir of formidable force. Normally, what happens with a so-called national consciousness is that it generates in the people a kind of emotional bondage. It forms the cultural undercurrent for solidarity of citizenry. With this, all the bonds which are formed among the members of a concrete community are transformed into a new and more abstract form of solidarity. The members of the same 'nation' feel so much responsible for each other, even if they are strangers to each other, that they are ready to 'sacrifice' their life for the defence of their country. ${ }^{2}$

The greatest accomplishment of a modern nation-state is, therefore, the formation of a cultural substrate of civic solidarity ("staatsbuergerliche Solidarität"), ${ }^{3}$ which is a pre-requisite for the institutional realisation of democratic selfdetermination of a people. This sense of civic solidarity creates socio-cultural contexts for public communication and political participation which ultimately allows a nation-state to materialise the political integration of the citizens of a larger society. This political integration of all the citizens is the distinctive achievement of a nation-state. But today there are signs of political fragmentation in the fortifications of the "Nation". 4

However, a democratic self-determination can only be realized, when the people's state transforms itself into a nation of citizens who themselves take over the political steering of the country. But this political mobilisation of the common man can be realized only through a cultural integration of the scattered disparate population. This needs a certain cosmopolitan strategy, which would enable the citizens to cultivate a new form of collective identity, which transcends the local loyalties towards the native village and family, the regional surroundings, and the dynasties. ${ }^{5}$

But this political integration is rooted in a general abstract understanding of constitutional principles which are derived from the perspectives of the nation's historical experience. This understanding is embedded in a common horizon of interpretation within which all current and topical issues are debated in a public sphere. And such public debates also make the political self-understanding of the citizens transparent.

Therefore, it is but obvious that in modern complex pluralistic societies social norms can derive their validity only from the reason and will of those, whose decisions and interactions are supposed to be bound by these norms.

The West (which also includes America) has two distinct advantages of its history: What happened towards the turn of the $18^{\text {th }}$ to $19^{\text {th }}$ century in Europe and

1 cf. Habermas, Jürgen: Postnationale Konstellationen, Frankfurt/M 1998, p.99f.

2 cf. ibid., p.100

3 cf. ibid., p.110

4 cf. ibid., p.110

5 cf. ibid., p.99 
America was that the perception of emancipatory trends started getting articulated in the ideas of people's sovereignty and human rights which were the direct consequences of the French Revolution and the American Revolution. These two significant events gave rise to a kind of egalitarian universalism which presupposes an intuitive inclusion of the other on equal terms, which facilitated the emergence of the consciousness of Individualism, a major feature of Western modernity.

Against this historical background we can perceive today the emergence of globalisation as a modern phenomenon which is encouraging two complementary developments. On the one hand, it (the globalisation) is encouraging the trend of multiculturalism and individualism on the tenets of this egalitarian universalism. On the other hand, it is posing a challenge to the existence of nation which came into being as an exclusive community of a people of common ethnic origin. By implication, globalisation is threatening to revoke the traditional fusion of the constitutional state with the monolithic 'Nation'. This challenge is a positive sign, a hope, which would enable us to renew a solidarity of citizenship in the sense of a cosmopolitan universalism, which is sensitive and receptive to cultural differences. ${ }^{6}$ The spirit of this universalism is today reflected in the processes of 'multiculturalism' and 'individualisation', which have shaken the foundations of a nation-state.

Globalisation is contributing to this development. Since the beginning of the Nineties of the last century this form of nation-state democracy has come under a considerable stress and pressure of Globalisation.

I understand the term of globalisation as a continuing process of transnational displacement of the established conventional institutions in the wake of an increasingly comprehensive and intensified mobility and transfer of human beings, information, and goods on the basis of instant communication, transport and exchange. Anthony Giddens defines Globalisation as the intensification of worldwide relations which interconnect the local happenings with distant events beyond the national borders. ${ }^{7}$.

Globalisation is accelerating the process of de-nationalisation in that it is pressurizing the nation-state to open up from within to a multiplicity of new or alien ways of life or life-styles and new community formations. In the social and cultural domain it starts with a new sense of consumerism: diverse varieties and choices of cuisine, clothing, fashions, films, music, entertainment, tourism, games, sports, hobbies, dumping of cheap consumer goods, outsourcing of business processing, hybridisation of languages, tourism, learning of foreign languages on the micro level and on the macro level, opening of new transnational markets, communication, transport, highways, cultural networking.

However, our normal understanding of a present day multicultural society relates to a constellation of several diverse communities existing side by side in their respective (ghettoized) spaces allowing not much communication with one an-

6 cf. ibid., p.128

7 Giddens, A.: The Consequences of Modernity, Cambridge 1990, p.64 
other. There is some kind of an anthropological nostalgia about the indigenous cultures which are supposedly getting marginalized in the wake of globalisation or uprooted under the pressure of commercial homogenisation or they are deprived of their presumed authenticity.

There is an interesting study ${ }^{8}$ by G. Baumann on identity formation in multiethnic groups which attempts to debunk the notion that different ethnic groups in multicultural societies form "watertight compartments", so to say "coherent totalities" with clearly demarcated culture-spaces. A traditional image of a multicultural discourse gives this static view of a cluster of closed ethnic groups.

But Multiculturalism is not a static phenomenon. Its dynamics lies in the grey areas of cross-border intermingling of cultures. In pluralistic societies there are always undercurrents of changes in the ethnic, religious and cultural composition of the population. Baumann adumbrates a dynamic image of an ongoing construction of new belongings, new sub-cultures and life-styles. This process of collateral give-and-take, intercultural contacts, and multiethnic connections is facilitating a process of formation of "cosmopolitan identities".?

Further, this cosmopolitan interaction among the diverse communities does not allow particularism, but facilitates pluralism, leaving each community its cultural space without competing with each other. Robert Brandom perceives this pluralistic aspect in the cosmopolitan approach: "The most cosmopolitan approach begins with a pluralist insight. When we ask, Who are we? or What sort of thing are we? the answers can vary without competing. Each one defines a different way of saying we; each kind of we-saying defines a different community. It points to the one great Community comprising members of all particular communities - the Community of those who say we with and to someone, whether the members of those different communities recognize each other or not". ${ }^{10}$

Several critical views about this cosmopolitan way of thinking have been expressed, particularly its relativistic stance towards the cultural identities. „But the cosmopolitan strategy is not to deny the role of culture in the constitution of human life, but it certainly questions, first, the assumption that the social world divides up neatly into particular distinct cultures, one to every community, and secondly, the assumption that what everyone needs is just one of these entities - a single, coherent culture - to give shape and meaning to his life" ${ }^{11}$

The problem of the contemporary complex pluralistic societies lies in the possible absence of an organically developed sense of solidarity which existed, in a certain sense, in all traditional societies in the form of religious, social, ethical integration of the population through religion or caste.

8 Baumann, G.: Contesting Culture. Discourses of Identity in multi-ethnic London, Cambridge 1996

9 Waldron, Jeremy: Minority Cultures and the Cosmopolitan Alternative, -in: Will Kymlicka (ed.): The Rights of Minority Cultures, Oxford 1995

10 Brandom, R. B.: Making it Explicit, Cambridge (Mass) 1994, p. 5

11 Waldron (1995) 
Today in India there is a new restlessness of transition from the religious forces of integration to the social and political forces of participatory awareness. In India there are more than 10 national TV news channels round the clock belonging to different political affiliations. Interestingly, the government channel which used to be the sole mediator and controller of national and international news has now been reduced to one of the many channels. This strong nationwide transparent and vigilant media presence from all possible ideological lobbies recognizes the coexistence of diverse forms of life with equal rights and ensures a 'mutual recognition' of different cultural communities.

Each community evolves its own understanding of what is good for them. So, in a pluralistic society all persons must also be recognized as members of the respective ethical communities, who are integrated around their conception of good. This ethical integration of these cultural groups and sub-cultures can evolve their own collective identities, but their integration must be de-linked from the "abstract political integration, which includes all citizens equally". ${ }^{12}$ This is the ethical basis for the formation of a cosmopolitan identity of the citizens.

Normatively, a democratic process is more congenial for the integration of multicultural groups and can be more effectively embedded in a common cosmopolitan political culture, since it does not have the exclusivist character of an ethno-national peculiarity. According to Habermas, this embedding is inclusivistic in the sense of self-legislation, which includes all citizens in equal manner, leading to a certain cosmopolitan awareness. ${ }^{13}$

Inclusion means that the political domain keeps itself open for the integration of all citizens of every ethnic origin, without however pressurizing the others into the uniformity of a homogenized people's community, where the majority culture overlaps with the general political culture.

In the case of German society, Habermas long advocated a "postnational" Germany, where shared identity is attached to non-territorial values of constitutionalism and democratic rights. In principle, so argues Habermas, humans possess a rational capacity to reason and communicate, and therefore they can come to agreement on the basic institutions of law, values, and politics. He is, however, less clear on how popular sovereignty and the collective will of global citizenry can take shape in a stateless world.

Globalisation alone does not contain the seeds of a better political order, and there are no doubt the dilemmas and ambiguities inherent in modernisation. But the social and political practice mediated through the communicative networks of public debates and media exposure will enhance the consciousness of cosmopoli$\tan$ values. They can be at least made transparent with the help of popular social and political movements, transnational networks of communication, NGOs, civic initiatives. In the midst of the current and contradictory phenomena of globalisa-

12 Habermas, J.: Inclusion of the Other, 1999, p.224f.

13 cf. ibid, p.112 f. 
tion, nationalism, and multiculturalism lies the slippery and difficult-to-define idea of cosmopolitanism.

Cosmopolitanism is also an expression of a kind of universalism, which is sensitive to cultural differences. ${ }^{14}$ It essentially encourages a consciousness of cultural ambivalence in that it displaces the subject from its tradition of identification and keeps it in the state of perpetual unmaking of its tradition.

Dileep Padgaonkar, an Indian journalist, while interviewing the Israeli writer, Amos $\mathrm{Oz}$, describes the consciousness of ambivalence of his identity when he describes:

„I was born a Hindu, in a certain caste. We have had 110 years of Muslim rule. I cannot ignore its contribution to the enrichment of Indian culture. And then we had Western rule and I cannot deny what they contributed to shaping me and my country. Therefore, I do not wish to be either apolegetic or aggressive about any of these components of my identity. The problem arises, when you are obliged to assert your Hinduness or Islamness, your Westernisation, in order to assert your identity. In fact, each of us has a cultural gene of the other. Our failure to recognize this has created horrible problems" .15

This is in a sense the manifestation of cosmopolitan consciousness of ambivalence. Societies, which have failed to evolve such a consciousness, have met with disasters and have to face enormous problems in achieving social and political integration. I see similar problems in the Indian context in the task of creating 'a secular state in a religious society'.

This pluralistic consciousness of a citizen is to be perceived as an encounter with the 'Other', which Thomas Mann describes as “a yearning for mutual exchange in diversity". ${ }^{16}$ But this yearning is not a unifying process of homogenisation. By blurring the contours of my identity I am still not the 'other', and yet I yearn to discover the 'other'. It is a „,neutral point“, as Todorov would put it, ${ }^{17}$ not in the sense of equidistance, but in the sense that both the self and the other are experienced from within. „Without becoming an Indian, Cabeza de Vaca was no more the same old Spaniard“.18 This is how Todorov describes the ,neutral point“ that the Spanish colonizer reaches in his encounter with American Indian culture.

India as a modern state with a traditional religious society draws its legitimation from its political order as a democratic constitutional state. But, this is possible only when democracy and constitutional state are internally cohesive. This cohesiveness is enabled only when the private and the public autonomy of the citizen are ensured by the state. The citizen would be able to make use of public auton-

14 cf. ibid., p.128

15 Padgaonkar, Dileep, -in: Times of India, Lit.Suppl., 7.3.1993, p.17

16 ,ein Verlangen nach Austausch in der Verschiedenheit“; vgl. Mann, Thomas: Die vertauschten Koepfe, München 1967

17 Todorov, Zwetan: Conquest of America, 1984, .p.294

18 ibid., p.294 
omy only when he is adequately independent to make use of his private autonomy which is assured to him in equal manner.

This aspect brings us to a basic issue concerning the normative questions of political claims and legal rights. The personal laws of the different religious communities are imbued with some ethical values of their respective communities. I understand 'ethical' in a rather restricted sense of something, which can be 'good' for a particular person or community. It is likely that some of the edicts of the personal laws may encroach upon the human rights guaranteed by the constitution. For example, all Turkish immigrant citizens in Germany are granted equal rights as individual citizens, but the orthodox Turks do not allow their daughters to study certain subjects at the university on account of some religious restrictions. Such collective rights based on old traditional beliefs would be incompatible with the constitutional provision of protection of individual rights. The state will have to intervene in it as in the case of sati in the early $19^{\text {th }}$ century India. It would not be sensible to legitimize community rights for the sake of mere survival of such traditional practices, though such a critical awareness should also emerge from within the community. The maintenance of such collective rights may be a cultural task, which can be legally enabled, but by no means granted.

In India the judiciary is also aware of the complexities and intricacies of a pluralistic society. There is a serious reflection over the relationship of minority cultures to the majority culture within a constitutional democracy. Moreover, it is concerned about the political aspects of majority-minority conflicts, a darker side of our political culture.

At the national level there are perceptions, which, however, give rise to two important questions relating to our political culture: By implication one asks whether the identity of an individual Indian citizen as a member of ethnic, cultural, or religious groups has any public relevance. If that is the case, how such collective identities should exist within the framework of constitutional democracy without having to suffer marginalisation.

These perceptions appear to be a kind of a combination of liberal and communitarian views. The liberal view grants equal rights and chances to every citizen irrespective of her caste, creed or colour. The communitarian approach is more interventionist in a manner which expects the state to safeguard the traditions and cultural forms of the minorities. It would not be inappropriate to assume that the Indian judiciary sees in the ambit of the common civil code a possibility to support a universally shared civic culture of our country, a culture, which recognizes and accommodates cultural differences. At the same time, such a culture should provide a 'neutral' (or shall we call it 'secular'?) public space, in which different communities can interact, compete and thus further strengthen the democratic foundation of the country.

An organized society evolves its own political culture which has grown over a long historical process and is commonly shared by the individual citizens. The constitutional principles are derived from the peculiarities of this political culture 
without however compromising on the 'universalist core' of these principles. All citizens irrespective of their cultural affinities share this common political culture which is the outcome of their shared history. It is this broad encompassing political culture which expounds the constitutional principles and should create a foundation for a constitutional patriotism, a concept, which Habermas has used to describe the political culture of the future pluralistic European Union.

According to Habermas, the constitutional state has the responsibility to nurture a shared political culture and a common civic identity. It is therefore incumbent on the multicultural societies to practice a "politics of (reciprocal) 'recognition' of different collective identities", ${ }^{19}$ since the identity of every single citizen is always interwoven with the other collective identities and also dependent on the stability of a "network of such a mutual recognition".

French Authorities have acknowledged the roots of their current problem, which are deep-seated, perhaps linked to the French approach to immigration which works to fit immigrant citizens, whatever their origins, into a single mould.

There needs to be a political culture which is to be shared equally by all citizens independent of their respective religious or cultural identity. But this shared political culture should remain neutral and separated from all particularistic cultures and collective identities, which are surely entitled to equal co-existence within the society. The state and its legal order, however, must maintain neutrality vis-à-vis these sub-cultures which are pre-political forms of life and traditions.

How does this neutrality express itself? "Remaining 'neutral' means - and this is the critical edge of neutrality - decoupling the majority culture from the political culture with which it was originally fused, and in most instances still is", says Habermas. "Decoupling the majority culture" is the most crucial element of the constitutional patriotism.

To my mind, the apprehension of those who oppose the uniform common civil code rightly lies in this fear that the majority culture would eventually be construed as the common "national" culture. The compulsion on the part of the minorities to accept such a 'national' culture, it is feared, may extend to 'assimilation to the way of life of the majority culture'. As it happens, the majority culture has always been historically blended with the general political culture of a monocultural nation-state.

Now it is this most problematic and precarious project which would be difficult to imagine in our present political context that in a pluralistic state like India the majority culture should delink itself from its historical fusion with the general political culture, if all other citizens should identify themselves with the general comprehensive political culture of India in the equal manner.

I see far-reaching consequences in the public debate in India in that it opens up a new vista of this political culture in the country. The renewed debate on the common civil code should adumbrate the future scenario for identifying the non-

19 cf. Kymlicka, W: Multicultural Citizenship, Oxford 1995 
majoritarian sources of legitimacy ${ }^{20}$ for our political culture. It would be incumbent on the political parties, the enlightened academic institutions and individual citizens to deliberate on the conditions of public communication for the formation of a rational political will of cosmopolitan vision.

At the beginning of the twenty first century, the world society is still facing growing global problems. Only an enlightened cosmopolitan visionary perception will be in a position to strengthen the trend towards the system of 'global governance' which is based on the acceptance of divided sovereignties, the strengthening of the global rule of law, and the recognition of universally valid values and principles which are conceived in the cosmopolitan sense of globality.

\section{Literatur}

Brandom, R. B.: Making it Explicit, Cambridge/Mass. 1994

Giddens, A.: The Consequences of Modernity, Stanford 1990

Habermas, J.: Postnationale Konstellationen. Poliische Essays, Frankfurt/M 1998

Habermas, J.: Inclusion of the Other, Cambridge/Mass. 1999

Kymlicka, W: Multicultural Citizenship, Oxford 1995

Kymlicka, W.: (ed.): The Rights of Minority Cultures, Oxford 1995

Mann, Thomas: Die vertauschten Koepfe, München 1967

Padgaonkar, Dileep, -in: Times of India, Lit. Suppl., 7.3.1993

Todorov, Zwetan: Conquest of America, N.York 1984

Waldron, Jeremy: Minority Cultures and the Cosmopolitan Alternative, -in: Will Kymlicka (ed.): The Rights of Minority Cultures, Oxford 1995, pp.93-122

20 A controversial concept intensely debated in the academic circles. 
Kommunikation über kulturelle Grenzen hinweg ist das ideologischpolitische Programm des indischen Staates seit seiner Gründung (,Unity in Diversity"), jedoch hat die Öffnung der indischen Ökonomie und Märkte vor anderthalb Jahrzehnten zu einer Konfrontation der indischen Gesellschaft mit anderen Gesellschaften und Kulturen geführt wie nie zuvor. Die technischen Errungenschaften der neuen Medien haben zudem die Kommunikation erheblich erleichtert. Die Fremdsprachen-Abteilungen der Universitäten im Lande haben infolgedessen eine qualitative Verschiebung in ihrer Zielsetzung erlebt: nicht nur das Verständnis von gedruckten Texten in Fremdsprachen ist heute von Relevanz sondern zunehmend auch die Gesellschaften und Kulturen, in denen diese Sprachen gesprochen werden.

Vor diesem Hintergrund organisierte die German Section of the Department of Foreign Languages, University of Pune, eine internationale interdisziplinäre Konferenz in Pune (7.-9. Januar 2008), bei der verschiedene praktische sowie theoretische Ansätze vorgestellt wurden, die den Prozess und die Mechanismen der interkulturellen Verständigung analysieren. Diese Publikation ist eine Sammlung von Beiträgen, die im Rahmen dieser Konferenz entstanden sind; sie stellen gegenwärtige theoretische Positionen, Forschungsmethoden sowie die Praxis der interkulturellen Kommunikation vor. 